


\section{NOVO ESPAÇO DA PRODUÇÃO: OS TECNOPOLOS}

Tese de doutoramento apresentada à Faculdade de Filosofia, Letras e Ciências Humanas da Universidade de São Paulo Departamento de Geografia -, como requisito parcial à obtenção do título de Doutor em Geografia Humana.

Orientador: Prof. Dr. Milton Almeida dos Santos

Universidade de São Paulo

Faculdade de Filosofia, Letras e Ciências Humanas - USP 
Editoração Eletrônica: Alberto Flávio Aguiar

Copydesk: João Vianney Viana

Capa: Rui Farias Carneiro

Cartografia: Ércio Flávio Viana Pessoa

Catalogação na Fonte. Biblioteca Helena Maria Souza

L732n Lima, Luiz Cruz
Novo espaço da produção: os tecnopolos/ Luiz Cruz Lima.
- São Paulo: Universidade de São Paulo, 1994.
$182 ; 27,94 \mathrm{~cm}$.
Tese (doutorado em geografia) - Universidade de São
$\begin{aligned} & \text { Paulo, 1994. Bibliografia: p. 171 - 182 } \\ & \text { 1. Inovações tecnológicas. 2. Universidade e inovações } \\ & \text { tecnológicas. 3. Empresa e inovações tecnológicas. I Título. } \\ & \text { CDD: } 338.064\end{aligned}$



constituída pelos professores

Prof. Dr. Milton Almeida dos Santos - Orientador 


\section{Agradecimentos}

Z mbora habituado, desde cedo, aos rigores da vida real, submeter-se novamente ao trabalho escolar com meio século de vida, só é possível com a colaboração efetiva e afetiva e com o incentivo de bons e verdadeiros amigos.

Expresso meus agradecimentos muito sinceros

- à minha companheira e amiga de toda hora, Márcia Helena Silveira de Souza, mulher e talento e muita fibra;

- ao querido primo e quase irmão, Lair Cruz Delcorço e família, símbolo de humanismo que falta a muitos;

- ao mestre Milton Santos, pelas palavras sábias e por sua grandeza de pessoa;

- à mestra Adélia de Souza, pelo apoio e atenção a mim dedicados;

- à colega Luzia Neide Coriolano que não mede sacrifícios para ser útil e colaboradora;

- ao mestre José Adelino Medeiros, pelo trato cordial e ajuda bibliográfica;

- à colega Zenilde Bayma Amora, pela atenção em ler e discutir o meu trabalho;

- aos colegas Paulo Petrola e Francisco Auto Filho, atuais gestores da Universidade Estadual do Ceará, pelo apoio e entusiasmo a mim concedidos;

- a tantas outras pessoas que me são atenciosas e gratificantes: Sérgio Gertel, Denise Elias, Socorro Diógenes, Ana Lúcia Torkomian, Artur Tavares Valverde, Rui Farias Carneiro e Helena Maria Souza, dedicada bibliotecária da UECE. 


\section{Sumário}

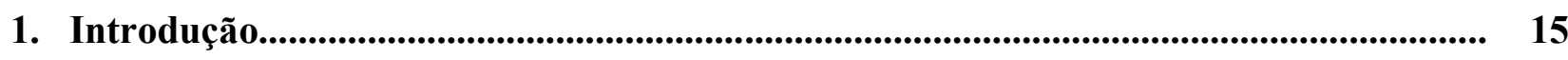

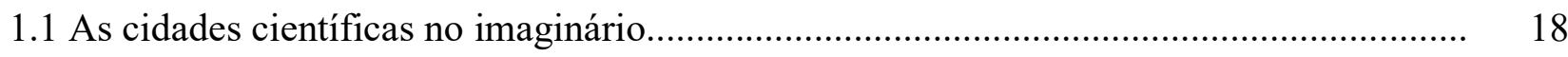

1.2 As cidades científicas no período técnico-científico........................................................... 24

2 A Reconstrução do Mundo Atual........................................................................................ 29

2.1 A grande ruptura e as novas trajetórias.......................................................................... 29

2.2 Esboço do regime flexível......................................................................................... 31

2.3 Adequação do Estado ao novo paradigma.................................................................... 33

3 Tecnopolo: Locus onde Germina a Inovação.......................................................................... 36

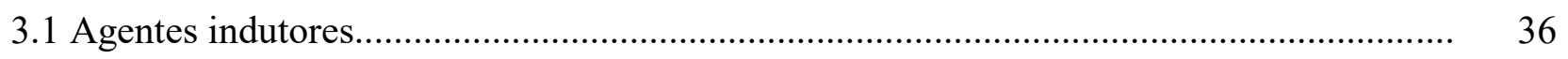

3.2 As bases da eficiência tecnopolitana............................................................................. 44

3.3 Tecitura do ambiente inovador.................................................................................. 51

3.4 Grandes demandas por inovações tecnológicas: fases........................................................ 65

4 A Territorialização dos Tecnopolos................................................................................. 73

4.1 Os tecnopolos nos Estados Unidos da América................................................................. 73

4.2 Os tecnopolos na Europa............................................................................................. 85

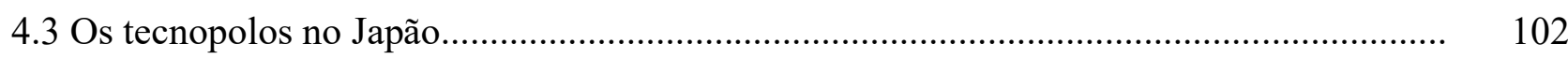

4.4 Os tecnopolos (pólos tecnológicos) no Brasil................................................................ 114

5 O Pólo Tecnológico de São Carlos-SP: Um Caso................................................................ 131

5.1 A organização espacial de São Carlos................................................................................. 131

$5.2 \mathrm{O}$ sistema de formação e pesquisa.............................................................................. 140

5.3 Alguns indicadores do nível técnico-científico de São Carlos............................................ 154

5.4 As empresas de alta tecnologia.............................................................................. 156

5.5 As relações empresas x Universidade e inter-empresas..................................................... 161

5.6 Atuação governamental.......................................................................................... 163

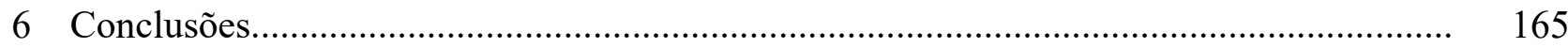

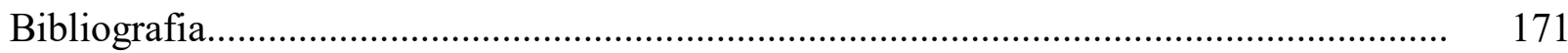




\section{Plantas e Mapas}

Tecnopolo do Vale do Hers, em Toulouse, França...................................................... 58

Estados Unidos da América: cidades com instituições acadêmicas (Ias).......................78

Estados Unidos da América: grandes universidades por Estado - 1992......................79

Estados Unidos da América: principais parques científicos e zonas High Tech...........83

Alemanha Ocidental: densidade demográfica..................................................... 92

Alemanha Ocidental: Centros tecnológicos e Universidades.....................................93

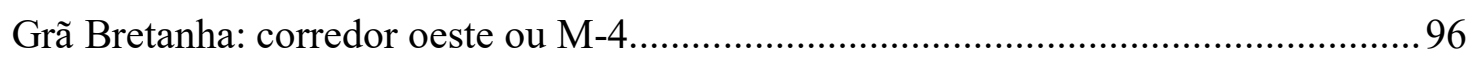

Grã Bretanha: regiões e zonas High Tech............................................................. 97

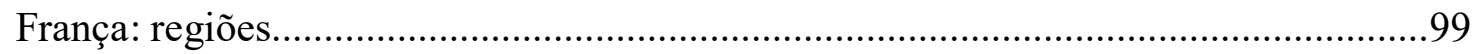

O desemprego por departamento................................................................. 100

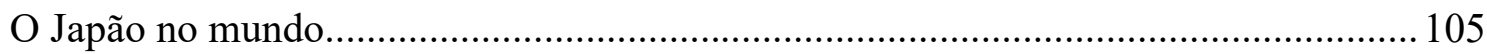

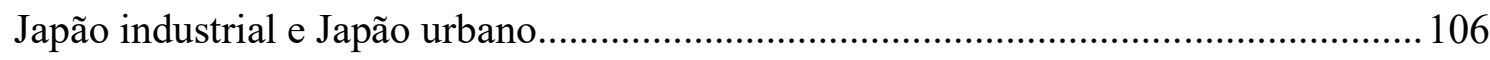

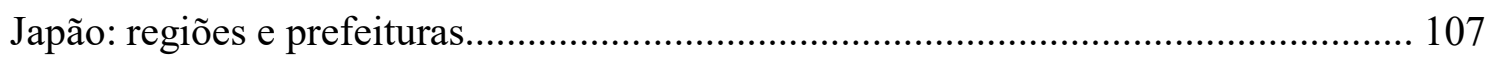

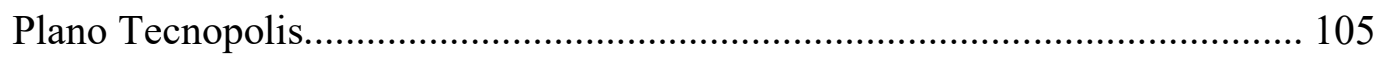

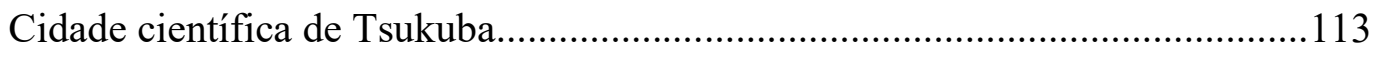

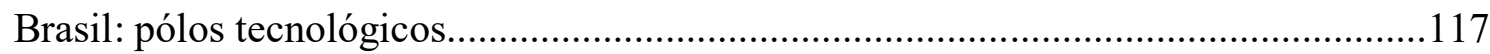

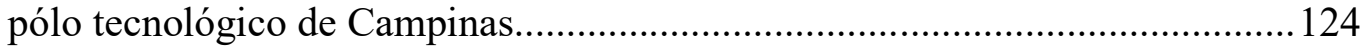

São Carlos: localização da região em São Paulo..........................................................136

malha viária da região..................................................................... 137

configuração da rede urbana da região.................................................. 137

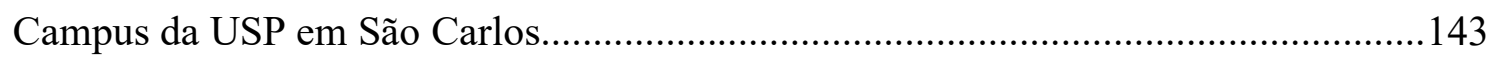

Campus da Universidade Federal de São Carlos........................................................ 146

São Carlos: universidade e núcleos industriais High Tech........................................ 162 


\section{Gráficos}

ESTADOS UNIDOS DA AMÉRICA: despesas militares em P x D...........................75

ESTADOS UNIDOS DA AMÉRICA: parques científicos criados........................... 83

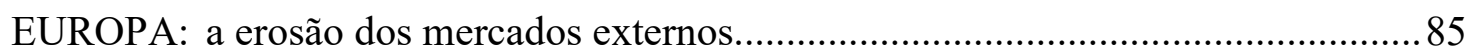

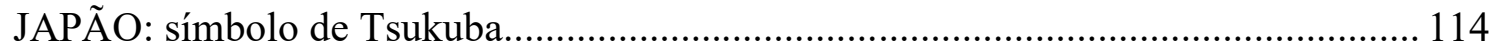

SÃO CARLOS: Diversificação do parque industrial, segundo pessoal ocupado.......... 134

SÃO CARLOS: Diversificação do parque industrial, segundo valor da produção........134

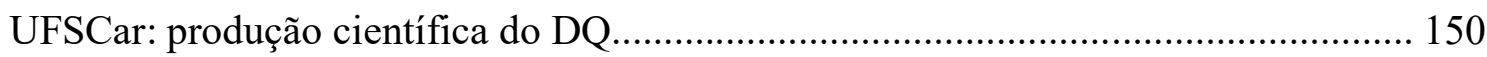

UFSCar: fontes dos recursos financeiros do DEMa................................................. 152

\section{Tabelas e Quadros}

ESTADOS UNIDOS DA AMÉRICA: Criação de tecnopolos de 1951 a 1975............68

Criação de tecnopolos mais dinâmicos de 1950 a $1977 \ldots . . . .68$

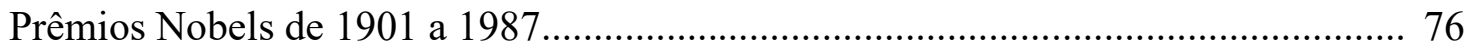

ESTADOS UNIDOS DA AMÉRICA: instituições acadêmicas (IAs)..........................77

universidades com mais de 10.000 alunos....80

principais parques científicos...................... 83

EUROPA: tecnopolos, ano de criação.........................................................................99

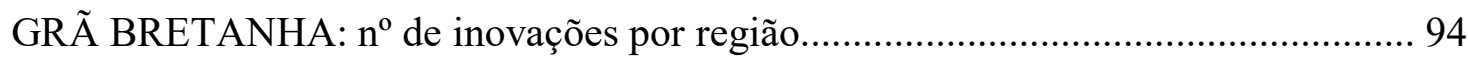

Participação regional de serviços de P x D.................................. 95

Tecnopolos por região..........................................................98

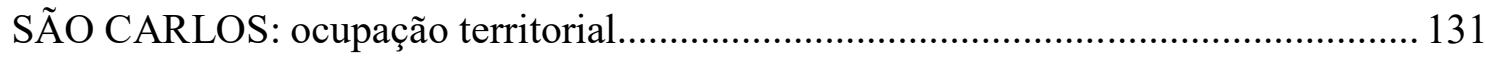

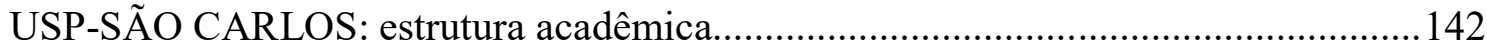

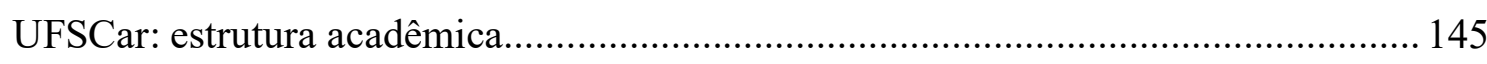

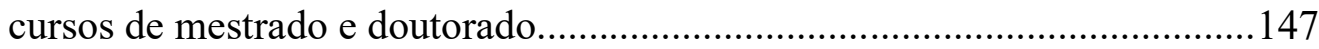

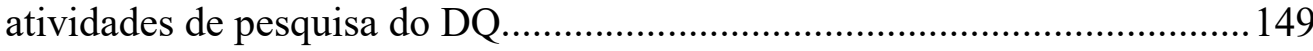

linhas de pesquisa do DEMa..................................................................... 151 
produção científica do DEMa. 151

Unidades acadêmicas isoladas de São Carlos......................................................... 152

SÃO CARLOS: evolução de instalação de empresas HT.............................................. 156

empresas aliadas a partir do DEMa............................................. 157

mercados das empresas High Tech.............................................. 159

aquisição de áreas do Distrito Industrial CEAT................................ 169 


\section{Siglas e Abreviaturas}

ABRABI : Associação Brasileira da Empresa de Biotecnologia

ACATE : : Associação Catarinense de Telemática e Eletrônica

AMPROTEC : Associação Nacional das entidades Promotoras de Empreendimentos de Tecnologias Avançadas

ARENA : Aliança Renovadora Nacional

ATECEL : : Associação Técnico-Científica Ernesto Luiz de Oliveira

AVIBRÁS : Industrial Aeroespacial S.A

BADEP : : Banco de Desenvolvimento do Paraná

BADESUL : Banco de Desenvolvimento do Estado do Rio Grande do Sul

BNDES : Banco Regional de Desenvolvimento do Extremo Sul

BIC : Centro de Inovação de Berlim

CAD/CAM : computer-aided design/computer-aided manufacturing ou desenho assistido por computador/fabricação assistida por computador.

CAPES : Coordenação de Aperfeiçoamento de Pessoal do Ensino Superior

CBPF : Centro Brasileiro de Pesquisas Físicas

CCSC : : Centro Cultural de São Carlos

CCT : Centro de Ciências e Tecnologia

CEAT : Centro Empresarial de Alta Tecnologia

CEDIN : Centro de Desenvolvimento de Indústrias e Nascentes

CEE OU MCE : Comunidade Econômica Européia ou Mercado Comum Europeu

CEFET : : Centro Federal de Educação Tecnológica

CEIMPAR : Centro Universidade-Empresa de Informática do Paraná

CEMEFI : Centro de Mecânica Fina

CENPES : Centro de Pesquisas e Desenvolvimento da Petrobrás

CERTI : Centro Regional de Tecnologias em Informática

C e T : Ciência e Tecnologia

CETEPE : Centro de Tecnologia Educacional para Engenharia

CETESC : Centro de Inovação Tecnológica de São Carlos 
CIATEC : Companhia de Desenvolvimento do Pólo de Alta Tecnologia de Campinas

CIENTEC : Fundação de Ciência e Tecnologia (Rio Grande do Sul)

CIESP : Centro de Indústrias do Estado de São Paulo

CITPAR : Centro de Integração de Tecnologia do Paraná

CNPQ : Conselho Nacional de Desenvolvimento Científico e Tecnológico

CNRS : Centre National de la Recherche Scientifique

CODETEC : Companhia de Desenvolvimento Tecnológico

CODEPAR : Companhia de Desenvolvimento do Paraná

COMECON : Conselho de Ajuda Econômica Mútua

COPPE : Coordenação de Programas de Pós-Graduação em Engenharia da Universidade Federal do Rio de Janeiro

CPLF : Companhia Paulista de Luz e Força

CPD : Centro de Processamento de Dados

CpqD : Centro de Pesquisa e Desenvolvimento da Telebrás

CRITT : Centro de Inovação e de Transferência de Tecnologia

CTA : Centro Tecnológico Aeroespacial

CTI : Centro Tecnológico de Informática

DATAR : Délégation à l'Aménagement du Territoire et à 1Áction Régionale

DEMA : Departamento de Engenharia de Materiais

DI : Distrito Industrial

DOD : Departamento de Defesa dos EUA

DPE : Distrito de Pesquisa e Educação

DS : Distrito Suburbano

DQ : Departamento de Química

EESC : Escola de Engenharia de São Carlos

EMBRAER : Empresa Brasileira de Aeronáutica

EMBRAPA : Empresa Brasileira de Pesquisas Agro-pecuárias

ENGESA : Engenheiros Especializados S.A.

ERATO : Investigação Exploratória de Tecnologia Avançada

ETE : Escola Técnica de Eletrônica

ETP : Espaço Técnico Produtivo 
FAFQ : Fundação de Apoio à Física e à Química

FAPERG : Fundação de Amparo à Pesquisa do Rio Grande do Sul

FAPESP $\quad$ : Fundação de Amparo à Pesquisa de São Paulo

FAST : Forecasting analysis for Science and technology (planejamento e avaliação no campo da ciência e tecnologia).

FEPASA : Ferrovia Paulista S.A

FETEC : Feira de Tecnologia de Campina Grande

FIESP : Federação das Indústrias do Estado de São Paulo

FINEP : Financiadora de Estudos e Projetos

FIPAI : Fundação para o Incremento da Pesquisa e do Aperfeiçoamento Industrial

FMI : Fundo Monetário Internacional

FNDCT : Fundo Nacional de Desenvolvimento Científico e Tecnológico

FIOCRUZ : Fundação Instituto Oswaldo Cruz

FPATSC : : Fundação Parque de Alta Tecnologia de São Carlos

FUND. BIO-RIO : Gerenciadora do Pólo de Biotecnologia do Rio de Janeiro

FUNTEC : Fundo de Desenvolvimento Técnico-científico

GATT : General Agreement Tariffs and Trade (Acordo Geral de Tarifas e Comércio)

GB ou UK : : Grã-Bretanha

GTT : Grupo de Transferência de Tecnologia

HT : High Tech (alta tecnologia)

HUDC : Corporação do Desevolvimento Urbano e da Habitação do Japão

IEA : Instituto de Estudos Avançados

IAC : Instituto Agronômico de Campinas

IAE $\quad$ : Instituto de Atividades Espaciais

IAS : Instituições acadêmicas

IBGE : Instituto Brasileiro de Geografia e Estatística

ICMSC : : Instituto de Ciências Matemáticas de São Carlos

IES : Instituições de ensino superior

IET : Incubadora Empresarial Tecnológica

IFI : Instituto de Fomento e Coordenação Industrial 


\begin{tabular}{|c|c|}
\hline IFQSC & : Instituto de Física e Química de São Carlos \\
\hline INATEL & : Instituto Nacional de Telecomunicação \\
\hline INPE & : Instituto de Pesquisa Espacial \\
\hline INPG & : Instituto Nacional Politécnico de Grenoble \\
\hline INT & : Instituto Nacional de Tecnologia \\
\hline IPAGRO & : Instituto de Pesquisa Agronômica \\
\hline IPAI & : Instituto de Pesquisa e Aperfeiçoamento Industrial \\
\hline ISS & : Imposto sobre serviços \\
\hline IPD & : Instituto de Pesquisa e Desenvolvimento \\
\hline IPT & : Instituto de Pesquisa Tecnológica do Estado de São Paulo \\
\hline ITA & : Instituto Tecnológico da Aeronáutica \\
\hline ITRI & : Instituto de Pesquisa em Tecnologias Industriais \\
\hline $\mathrm{LNCC}$ & : Laboratório Nacional de Computação Científica \\
\hline $\mathrm{MCT}$ & : Ministério de Ciência e Tecnologia \\
\hline MEC & : Ministério de Educação e Tecnologia \\
\hline MIT & : Massachusetts Institute of Technology \\
\hline MITI & : Ministério da Indústria e do Comércio Internacional do Japão \\
\hline NET & : Novas Empresas Tecnológicas \\
\hline NIT & : Núcleo de Inovação Tecnológica \\
\hline NPDIA & : (antes Uapdia). Núcleo de Pesquisa e Desenvolvimento de \\
\hline & Instrumentação Agro-pecuária \\
\hline NUTEC & : Fundação Núcleo de Tecnologia Industrial do Estado do Ceará \\
\hline OCDE & : Organização para a Cooperação e Desenvolvimento Econômico \\
\hline OTAN & : Organização do Tratado do Atlântico Norte \\
\hline PACTO & : Programa de Administração em Ciências e Tecnologia \\
\hline PADCT & : Programa de Apoio ao Desenvolvimento Científico e Tecnologia \\
\hline PAQ-TQ-PB & : Parque Tecnológico da Paraíba \\
\hline PATSC & : Parque de Alta Tecnologia de São Carlos \\
\hline PBDCT & : Plano Básico de Desenvolvimento Científico e Tecnologia \\
\hline$P \times D$ & : Pesquisa e desenvolvimento \\
\hline PME & : Pequena e Média Empresa \\
\hline PII & : Projeto de Informática Industrial \\
\hline
\end{tabular}


: Alemanha Ocidental

RIOTEC S.A. : Administradora do Pólo de Tecnologia do Rio de Janeiro

SCT-PR : Secretaria de Ciência e Tecnologia da Presidência da República

SEBRAE : Serviço de Apoio às Micro e Pequenas Empresas

SEI : Secretaria Especial de Informática

SENAC : Serviço Nacional de Aprendizagem Nacional

SENAI : Serviço Nacional de Aprendizagem Industrial

SJC : : São José dos Campos

SNDCT : Sistema Nacional de Desevolvimento de Ciência e Tecnologia

SRS : : Santa Rita do Sapucaí

STC : Sistema Técnico-Científico

TECNASA : Eletrônica Profissional S.A.

TECPAR : Instituto de Tecnologia do Paraná

TIP : Parque de Tecnologia e Inovação

UCLA : Universidade da Calofórnia

UFPB : Universidade Federal da Paraíba

UFCSC : Universidade Federal de Santa Catarina

UFSCAR : : Universidade Federal de São Carlos

UFPR : : Universidade Federal do Paraná

UNICAMP : Universidade de Campinas

UKSPA : United Kingdom Science Park Association

UNIVAP : Universidade do Vale do Paraíba

UTB : Universidade Técnica de Berlim

UTC : Universidade Tecnológica de Compiègne

ZIRST : Zona para Inovação e Realizações Científicas e Técnicas

ZTA : Zona de Telecomunicações Avançadas 


\section{Resumo}

$\mathrm{O}$

presente trabalho procura analisar um dos aspectos do meio técnico-científico informacional, decorrente do processo de mudanças por que passa o mundo, nestas últimas três décadas do século. Trata-se do elevado grau de adensamento do saber e do fazer, da maior aproximação do "design" e da fábrica, que obedece normas organizacionais exigidas pelas inovações tecnológicas, definidoras de novo paradigma técnico-econômico que abre um período ascendente de acumulação capitalista. Para atingir esse novo patamar, agentes vário se entrecruzam em sinergia: universidades, governo, capital financeiro e empresas.

O surgimento de núcleos e indústrias e serviços, em torno de ambientes dotados de elevado nível técnico-científico, vem propiciando um tipo específico de organização espacial, a que denominamos tecnopolo. Inicialmente, nos países centrais, mas hoje também presentes nos países do $3^{\circ}$ Mundo, os tecnopolos revelam-se como um instrumento de reorganização do sistema produtivo e, $\mathrm{m}$ decorrência, do espaço geográfico.

O tecnopolo, ao mesmo tempo que leva o lugar à globalização, ele o reduz à fragmentação, à medida que segue a especialização em algum lugar do setor da alta tecnologia.

Esse fenômeno liga-se ao esforço do capitalismo, desde a década de 1970, com a crise geral do regime de acumulação fordista, na busca de novos meios para elevar a produtividade e reconquistar os mercados e os altos lucros. Para retomar a marcha do crescimento, com as inovações tecnológicas - informática, novos materiais, biotecnologia, etc - novas regras se impõem à sociedade: reestruturação as relações de produção, uso de varias modalides de flexibilidade nas linhas de produção e nos regimes de trabalho, abertura das fronteiras nacionais, institucionalização de normas neoliberais. Ao mesmo tempo que beneficia as empresas, essa novas (des) ordem vem surtindo efeitos negativos sobre a massa dos menos qualificados, cada vez menos excluídos e segregados.

Desde os anos 80, o Brasil se insere no movimento tecnopolitano, pelo menos nos centros onde é mais presente a convivência da pesquisa com o setor produtivo. Como caso expressivo, tomamos São Carlos, no interior de São Paulo, para um estudo mais particularizado.

O espaço geográfico, em vários países e regiões, já revela as marcas do fenômeno tecnopolitano: quer em sua espacialidade, com a formação de regiões do tipo Vale do Silício (EUA), quer na conformação urbana com as cidades científicas, as tecnópoles. 


\section{$\underline{\text { Introdução }}$}

A nucleação de indústria e serviços, em torno dos centros de formação e pesquisa, é um fenômeno espacial típico do último quarto do século, marcante como foram os distritos industriais nos decênios anteriores. Estes últimos provinham do planejamento, atendendo à política de desconcentração e com proposta de desenvolvimento local e regional, muitos com base na teoria dos pólos de crescimento. Eram fortalecidos como instrumentos de reordenamento territorial das indústrias, dimensionado pelos fatores locacionais, numa fase de plena expansão do sistema econômico mundial.

A ressurgência de aglomerados das unidades produtivas marca-se por novas mediações: absorção de inovações tecnológicas como processo interno de mudança da estrutura de produção. O ponto de sustentação das novas necessidades da produção não se restringe aos fatores tradicionais de localização. Agora, exige-se um ambiente envolto em conhecimento técnico e científico, capaz de impulsionar a mecânica que se emperrara na contínua crise do sistema, a partir dos anos 70. A inserção do capital nesse terreno de fértil criatividade se faz pela cooperação contratual entre pesquisa e formação/governo/empresas.

Com as novas práticas, implanta-se novo tipo e meio técnico-científico informacional: os tecnopolos. Inicialmente, nos países desenvolvidos, onde estavam pré-estabelecidas as melhores condições necessárias, sequenciadas por outros países dos demais continentes, onde se faz com elevados esforços de investimento. Decorrentes das diferentes realidades nacionais e regionais, os tecnopolos revelam-se com modelos variados, ora como núcleos de promoção de inovações, com os distritos industriais de alta tecnologia (science parks), ora como globalizadora da vida urbana, com as cidades científicas ou tecnópoles.

Deum modo ou de outro, os tecnopolos simbolizam a revolução tecnológica moderna e a reestruturação das forças produtivas atuais, ainda em marcha. Eles impõem nova realidade sócio-econômica e política para o século que se avizinha.

Sua repercussão na via da sociedade e, portanto, no espaço, é notória. É realçada nos fluxos e nos fixos. Onde se faz presente, a dinâmica relacional dos espaços é mais intensa e ampliada e de maior qualificação os circuitos espaciais de produção. Para atender às novas funções, os lugares tecnopolitanos acatam novos objetos (ou fixos), objetos mais inteligentes e ágeis que, por sua vez provocam mais movimento, mais dinâmica ao espaço (Santos, 1988).

O elevado volume e a alta qualidade dos fluxos desses lugares expressam o valor das forças produtivas neles presentes, o que tem despertado o interesse locacional dos negócios, tornando-os mais inseridos na mundialização. Daí a singularidade e a especificidade (Santos, 1988:34) do tecnopolo como lugar-mundo.

O lugar-mundo, no entanto, já estivera presente noutras épocas. No passado mais distante, vários foram os pontos do Velho Continente que edificaram seu poder mundial, detentores das técnicas e do comércio.

Além da realização histórica desses lugares, outros foram idealizados e delineados por pensadores e filósofos, antevendo, talvez, o futuro que hoje vivemos. Para a concretude dos projetos visionários 
foram necessários séculos de passos e descompassos que só a história nos ensina.

Para melhor compreensão do período atual, delimitamos a "área temporal de significação" em que se insere nosso objeto de estudo, ou seja, esboçamos as linhas gerais da realidade mundial onde se contextualizam as variáveis do fenômeno tecnopolitano.

Relativamente a esses aspectos nos norteamos em duas bases teóricas: as ondas ou ciclos logos (ciclo Kondratieff) e a Escola da Regulação. A primeira nos dá a compreensão do surgimento das fases sucessivas de crescimento-depressão, consideradas as inovações revolucionárias próprias de nossa época. A segunda nos aponta os delineamentos do novo regime de acumulação que se vem elaborando com requisitos neoliberais, paulatinamente regulados pelo poder do Estado e reforçados pelas condições técnicas do presente.

Situado temporalmente, passamos a defini-lo geograficamente, isto é, definir a formaconteúdo desse novo tipo de espaço. Para isto, tentamos discernir o princípio ativo (Santos, 1985:2) da vida dos tecnopolos, analisando os agentes indutores onde se realizam os processos básicos de elaborarão de sua configuração geográfica e de sua dinâmica social. É por esta sequencia metodológica que se compreende a alteração das funções de cada elemento e do tecnopolo globalmente, conforme a fase de demanda (item 3.4) que determina a ação das partes (empresa, instituições de pesquisa, governo, etc.).

Em cada fase das granes demandas por inovações há diferentes forças sociais incidindo sobre os lugares privilegiados, afeiçoando-os como localizações adequadas à instalação de um tecnopolo. Essa afeição é muito definida pelos equipamentos e a tessitura do ambiente inovador, a que no referiremos mais adiante, (itens 3.2 e 3.3), e comprovado no estudo da territorialização dos tecnopolos e, com outros detalhes, no caso de São Carlos, São Paulo Brasil.

Os temas abordados se aproximam e justificam o que expressa Santos (1985:3): "Cada lugar, ademais, tem, a cada momento, um papel próprio no processo produtivo. Só a produção propriamente dita tem relação direta com o lugar L e dele adquire uma parcela das condições de sua realização. (...) Aliás, a própria segmentação tradicional do processo produtivo (produção propriamente dita, circulação, distribuição, consumo) muito ganharia em ser corrigida para incluirmos, em lugar de destaque, como ramos autorizados do processo produtivo propriamente dito, a CONCEPÇÃO (pesquisa), o CONTROLE, a COORDENAÇÃO, a PREVISÂO, paralelamente à MERCADOLOGIA (marketing) e à PROPAGADA. Ora, a organização atual do espaço e a chamada hierarquia entre lugares passou a dever grandemente, na sua realidade e na sua explicação, a esses novos elos do sistema produtivo". Na verdade, esses elos do sistema produtivo estão muito presentes e vivos os lugares por nós abordados, como os nexos referidos. De certo modo, a relevância do que apresenta a citação imediatamente anterior nos reforçou o interesse pelo tema agora desenvolvido.

No que se refere ao tratamento do objeto e estudo em si, os tecnopolos ou os pólos tecnológicos (terminologia usual no Brasil), as colaborações provieram de múltiplas fontes: bibliografia, (livros, revistas, atlas, jornais, documentos oficiais, anais de eventos acadêmicos), entrevistas (com especialistas no assunto, empresários, autoridades, pesquisadores), gravações (vídeos, cassetes), cursos, conferências e aplicações de questionários.

A produção da literatura sobre o assunto no Brasil ainda está limitada a poucos estudiosos, especialmente engenheiros e economistas. Muitos dos trabalhos se têm dedicado a casos específicos do País, não havendo aprofundamento em relação à formulações teóricas, talvez em virtude da jovialidade do tema no Brasil. Somente nesta década (1990), têm vindo à tona dissertações e teses 
sobre o assunto, embora desde o meado dos anos 80 o CNPq venha trabalhando o tema e o $\mathrm{PACTo/USP}$ tenha em suas reuniões discutido a questão no âmbito C e T.

Recente trabalho (Jóia, 1992) inclui a geografia brasileira nas preocupações com os pólos tecnológicos, vistos como espaços de alta tecnologia, vertente muito abordada por geógrafos de outros países, entre os quais o Prof. Allen Scott, na UCLA, e George Benko, da Sorbonne, Paris.

Além de vários autores franceses, também tivemos a contribuição de textos de pesquisadores dos EUA e de alguns outros países a Europa e, também, do Japão.

No estudo da territorialização dos tecnopolos, preferimos realçar os elementos locacionais, embora no caso japonês nos tenhamos estendido na descrição dos lugares tecnopolitanos.

Escolhemos o Brasil como demonstrativo de país do Terceiro Mundo com pólos tecnológicos. Dentre os 10 em funcionamento, destacamos o de São Carlos, em São Paulo.

A especificação do tecnopolo de São Carlos se deve, num plano mais amplo, a demonstrar como se formou um lugar privilegiado, nas condições de ciência e tecnologia, na formação econômica cultural. Daí o close na vida acadêmica e na história dessa cidade interiorana de São Paulo.

A opção por este pólo, dentre os demais no Brasil, explicamos pelas seguintes razões:

1 - originalidade da criação do Pólo: aproveitar a massa de pesquisa existente, orientar-se para a formação de PME de base tecnológica; pequenas empresas foram, na sua maioria, originadas por iniciativa de professores e alunos e não havendo superposição de grandes empresas privadas ou públicas;

2 - configuração industrial (de base tecnológica) própria, ainda em formação;

3 - ser um centro médio, podendo apresentar-se como modelo mais aproximado para outras regiões do País;

4 - o fato de a criação do pólo tecnológico ter-se originado no meio universitário, agregando parceiros locais.

A par desses dados preliminarmente, procuramos detalhar os elementos que nos possibilitasse melhor compreender, não apenas a especificidade local, como também o processo de formação de um pólo tecnolólgico.

Assim o fizemos por compreender que "os homens e suas atividades não se acham em sua presente localização exclusivamente por causa da interação de fatores atuais. Uma localização presente muitas vezes resulta, direta ou indiretamente, de fenômenos que deitaram raízes previamente. É por isto que o estudo de localizações individuais, assim como o estudo da organização do espaço, não pode passar por cima da dimensão temporal (Santos, 1979:42).

Garimpar um tema tão recente e, anda, sem muita definição, requer uma flauta mágica para não se perder no cipoal de tantas ideias e mitos de que vem carregada a literatura existente no mundo. 


\subsection{As cidades científicas no imaginário}

Abrimos nosso trabalho com uma breve seleção de textos de famosos autores da literatura universal. Todos tratam de aspectos de imaginárias cidades científicas em diferentes épocas, do Renascimento ao início do século XVIII, décadas antes da Primeira Revolução Industrial.

Nessa incursão pela literatura, encontramos alguns toques do imaginário, do mito que no correr do tempo, em certos casos, tem se convertido em realidade, em objetividade. No concreto atual, estariam algumas marcas dessa fantasia no passado?

Diz-nos Alceu Amoroso Lima, na Introdução de A Cidade do Sol que Thomas Morus, com sua Utopia de 1516, "abriu o caminho para o mito da cidade perfeita, na terra" (1966). Ao tratar da República da Utopia, ou mais particularmente da cidade Amaurota, Morus evidencia o significado das ciências e das artes, como meio fundamental para desenvolver as faculdades intelectuais dos cidadãos utopianos. Alguns excertos procuram alinhar essa visão. Vejamos.

"A ilha da Utopia tem dois mil passos na sua maior largura, ficando esta situada na parte média da ilha.

"A ilha contém cinquenta e quatro cidades amplas e magnificas. A mais curta distância entre essas cidades é de vinte e quatro milhas. Amaruota é a capital da ilha.

"Amaruota está edificada numa suave coluna e tem forma quase quadrangular. Começa pouco acima do cume da colina e prolonga-se por cerca de dois mil passos nas margens do rio Anidro, aumentando à medida que se costeia o rio.

Os habitantes das duas cidades cuidam com paixão dos seus jardins, onde cultivam a vinha e as árvores frutiferas, flores e toda espécie de plantas. Aplicam nessa cultura tal ciência e tal gosto, que eu nunca vi em outra parte qualquer tanta fertilidade e abundância ligadas a tão bom gosto.

Os utopianos dividem o seu dia de vinte e quatro horas exatas em periodos cuidadosamente determinados. Seis dessas horas dedicam-nas aos trabalhos materiais.

Há todas as manhãs cursos públicos que começa antes do nascer do Sol. Só os individuos especialmente destinados às letras são obrigados a seguir tais cursos. Toda a gente tem no entanto o direito de a eles assistir, tanto as mulheres como os homens, quaisquer que sejam as suas profissões. O povo acorre a esses cursos em grande multidão, escolhendo cada indivíduo de preferência o ramo de ensino em mais estreita relação com o seu engenho e os seus gostos.

Alguns, durante as horas de liberdade, entregam-se de preferência a exercitarse no respectivo ofício. São aqueles cujo espírito não gosta de elevar-se a especulações abstratas. Ninguém por tal os censura. Em vez de o impedirem, aprovam pelo contrário este intento de se tornarem constantemente úteis aos seus concidadãos.

À noite, terminada a ceia, os utopianos passam uma hora em divertimentos: no Verão, nos jardins de inverno, nas grandes salas onde em comum tomam as refeições. Enquanto uns dão ou ouve concertos, outros distraem-se conversando. Não têm noticia nem de dados, nem de cartas, nem nenhum dos jogos de azar tão estúpidos como perigosos. Praticam, no entanto, duas espécies de jogos que têm muita semelhança com o nosso 
xadrez: o primeiro é a batalha aritmética, o qual o número vence o número; outro é o combate dos vícios e das virtudes. Ali, em toda a extensão da cidade e do seu território, há, quando muito, quinhentos indivíduos, entre homens e mulheres isentos de trabalhar. Estão neste número compreendidos os sifograntes; e contudo estes magistrados são tão ativos como os outros cidadãos para os estimularem pelo seu exemplo. Estende-se também o privilégio aos jovens que o público consenso destina às ciências e às letras por recomendação dos sacerdotes e mediante sufrágio secreto dos sifograntes. Se um destes eleitos não corresponde às esperanças públicas, relegam-no para a classe dos operários. Se, pelo contrário, caso frequente, um operário que consagre as horas e lazer aos estudos intelectuais, adquirir bastante instrução, isentam-no de trabalho mecânico e elevam-no à classe dos letrados.

Entre os letrados se escolhem os embaixadores, os sacerdotes, os traniberos e o príncipe, outrora chamado bazzame e hoje ademe. $O$ resto da população continuamente ativa só exerce funções úteis, produzindo em períodos curtos uma massa considerável de obras-primas.

"O alvo das instituições sociais na Utopia é em primeiro lugar, corresponder às necessidades do consumo público e particular, deixando a cada cidadão o maior tempo possível para se libertar da servidão do corpo, cultivar livremente o espírito, e desenvolver as suas faculdades intelectuais pelo estudo das ciências e das artes. Neste desenvolvimento completo consiste para eles a verdadeira felicidade."

Considerada a técnica como meio de o homem conquistar e domar a natureza, Morus aviva-nos os resultados do trabalho no cultivo da terra. Prolonga a demonstração do valor e da expressão da técnica na dimensão temporal do cotidiano: na métrica do tempo mais curto - o dia - e, depois, na escala do período das estações. No diapasão da racionalidade extrema da sociedade imaginada, cada indivíduo, conforme sua qualidade intelectual e operacional, se enquadra numa categoria estamental. Para todos, no entanto, o princípio geral para conquistar a "verdadeira felicidade" é cultivar o espírito "pelas ciências e pelas artes:".

A dimensão da "felicidade" estaria no pleno domínio das coisas e na ampliação dos limites do homem?

Um século depois de Morus, a questão nos é posta por Bacon, ao propor a definiç̧ão das oficinas do saber técnico que amplia "os limites do império humano".

Além de uma simples descrição, em "Nova Atlântida" (1627), Francis Bacon, segundo seu secretário William Rawley, apresenta um modelo de "colégio instituído ara a interpretação da natureza e produção de grandes e maravilhosas obras para o benefício do homem".

Nesse último trabalho do filósofo inglês, editado em 1627 um ano após a morte, está a descrição minuciosa da Casa de Salomão, onde reinam "a harmonia e o bem-estar dos homens".

Parte da descrição do ambiente científico imaginado por Bacon segue aqui:

"O fim de nossa instituição é o conhecimento das causas e dos segredos dos movimentos das coisas e a ampliação dos limites do império humano para a realização de todas as coisas que forem possíveis. 
Possuímos amplas cavernas, com vários graus de profundidade, e as mais profundas penetram a terra por mais de seiscentas braças. Chamamos essas cavernas de regiões inferiores e usamo-las para todas as experiências de coagulação, endurecimento, refrigeração e de conservação de corpos.

Temos altíssimas torres, a mais alta medindo cerca de meia milha; algumas delas se ergue sobre montanhas. Chamamos a esses lugares superiores, considerando o ar que fica entre os lugares altos e baixos como regiões intermediárias. Tais torres, conforme sua altura e posição, servem para os experimentos de isolamento, refrigeração e conservação e para as observações atmosféricas, como o estudo dos ventos, da chuva, da neve, granizo e de alguns meteoros ígneos.

"Temos, ainda, casas grandes e espaçosas, onde imitamos e reproduzimos os fenômenos meteorológicos, como a neve, granizo, a chuva e algumas chuvas artificiais de substâncias diferentes da água, trovões, relâmpagos, bem como criações de rãs, moscas e outros pequenos animais.

"Temos ainda diversas artes mecânicas, que não possuis, bem como produtos obtidos por meio delas, como o papel, o linho, a seda, tecidos, delicados trabalhos de penas de extraordinário brilho, tinturas excelentes e muitos outros produtos.

"Temos também vários tipos de fornos e de várias intensidades de calor, violentos e rápidos, fortes e constantes, tépidos e suaves, impetuosos, tranquilos, úmidos, secos, e outros. Mas, sobretudo, temos calores que imitam o calor do sol e dos corpos celestes, passam por diversos graus de intensidade e que, por assim dizer, estão sujeitos a órbitas, ciclos e retornos periódicos, e com os quais conseguimos notáveis efeitos.

"Temos também casas de perspectiva, nas quais fazemos demonstrações de todas as luzes e radiações, e cores. Dispomos de meios de ver os objetos a distância, como os do céu e dos lugares remotos do espaço, e também para fazer parecerem distantes coisas próximas e próximas coisas distantes, criando distâncias fictícias.

"Temos também casas de máquinas onde são preparados os instrumentos e as máquinas para todo tipo de movimento. Fabricamos ainda armas de fogo, instrumentos de guerra e máquinas de todos os tipos e, igualmente, novas misturas e composições de pólvora, de fogo grego, que queimam na água e que não conseguem extinguir. Imitamos ainda o vôo dos pássaros e dispomos de algumas formas de voar pelo ar; navios e barcos que vão sob a água e que são capazes de suportar a violência dos mares, como também cinturões de segurança e de sustentação.

"Temos ainda uma casa de matemática, onde são conservados todos os instrumentos, perfeitamente construídos, necessários à geometria e à astronomia.

"Por fim, fazemos o circuito e visitas periódicas às principais cidades do reino e nessas, segundo a necessidade, tornamos públicas as novas e mais úteis invenções, de acordo com o que nos pareça oportuno. Fazemos também predições de doenças, pragas, invasões de animais nocivos, escassez, tempestades, terremotos, grandes inundações, cometas, estações do ano e de diversas outras coisas e oferecemos conselhos sobre o que deve ser feito para preveni-los e prepará-los. 
Na sequência do que nos apresenta sobre a Casa de Salomão, Bacon nos demonstra uma série de conceitos que a ciência só viria dominar séculos depois. As experiências laboratoriais revelam a capacidade de domínio do homem, não só de orientar os fenômenos, como também de difundir ou transferir tecnologias a outras comunidades, para a "harmonia e bem-estar dos homens".

Essas novas dimensões, a que leva o processo das ciências e das técnicas, continuam sendo tema de expressão urbana no Renascimento. Repetiremos Alceu Amoroso Lima: "a cultura renascentista irradiava para fora e se expandia nas cidades", cidades onde tinha expressão a febre científica.

Participante da abertura do mundo moderno, com o Renascimento, Tommaso Campanella, em "A cidade do Sol" (1623) postula o mito da cidade perfeita. "Perfeita" na feição de obediência aos parâmetros tecnológicos que levam a prender "todos os habitantes o mundo num só ovil".

A compartimentação, ordenação dos círculos que hospedam todas as ciências traçam o perfil que na primeira metade do século XX, Aldous Huxley retrataria, em seu "Admirável Mundo Novo" a cadeia a que nos levariam os progressos das técnicas. Viajemos, um pouco, com Tommaso Campanella.

"A maior parte da cidade está situada sobre uma alta colina que se eleva no meio de vastíssima planície. Mas as suas múltiplas circunferências se estendem num longo trecho, além das faldas do morro, de forma que o diâmetro da cidade ocupa mais de cem milhas, por sete do recinto total. A cidade foi construída em sete círculos e recintos particularmente designados com os nomes dos sete planetas. Distinguem-se os grandiosos palácios que, de tão unidos uns aos outros, parecem mas um só edificio. A meia altura desses palácios, vêem-se surgir, de fora para dentro do círculo, várias arcadas com galerias superiores, sustentadas por elegantes colunas e circundando quase toda a parte inferior do pórtico, à maneira dos peristilo ou dos claustros religiosos. O supremo regedor da cidade é um incessantemente assistido por três chefes, chamados Pon, Sin e Mor, nomes que, entre nós, equivalem a Potência, Sapiência e Amor.

"Sapiência, além disso, com ordem admirável, fez adornar as muralhas externas e internas, superiores e inferiores, com preciosissimas pinturas representando todas as ciências.

$\mathrm{Na}$ parte interna do primeiro círculo, foram pintadas todas as figuras matemáticas. Um breve conceito, contido num verso, faz conhecer o significado e cada uma, com definições, proposições, etc.

No interior do segundo círculo, ou seja, das segundas casas, estão todos os gêneros de pedras preciosas e comuns, de mineras e metais. Na parte externa desse círculo aparecem indicados todos os mares, rios, lagos e fontes da terra, assim como os vinhos, óleos e licores, com a sua procedência, qualidade e propriedades. Os cidadãos solares 
conhecem também a arte pela qual se podem reproduzir, dentro de uma habitação, todos os fenômenos meteorológicos, os ventos, as chuvas, o trovão, o arco-íris, etc.

No interior do terceiro circulo, encontram-se as gravuras de todos os gêneros de plantas e ervas. As declarações que lhes vão anexas ensinam o lugar da primeira descoberta, as suas forças, propriedade e relações com as coisas celestes, com as diferentes partes do organismo humano, com as produções metálicas $e$ marinhas, e também o uso particular de cada uma em medicina, etc.

No interior do quarto círculo, estão representadas todas as espécies de pássaros, suas qualidades, grandezas, indoles, costumes, cores e vida.

No interior do quinto círculo, aparecem todos os gêneros de animais terrestres mais perfeitos, num número portentoso.

$O$ interior do sexto círculo, encontram-se pintadas todas as artes mecânicas e os seus instrumentos, e como as usam as diversas nações, cada uma ordenada e explicada segundo o próprio valor, e trazendo também o nome do inventor respectivo.

Há professores que explicam essas gravuras, habituando as crianças com menos de dez anos a aprender sem fadiga, como uma espécie de divertimento todas as ciências, mas tudo pelo método histórico. As ciências são aprendidas com tanta facilidade que as crianças ficam sabendo num ano o que entre nós só se adquire depois de dez ou quinze anos de estudo.

Dizem os solares que em nossos dias, num período de cem anos, acontecem mais fatos dignos de história do que nos quatro mil na o do mundo anterior. Não cessam de elogiar a invenção da imprensa, da pólvora e da bússola, sinais particulares e, ao mesmo tempo, instrumentos da união de todos os habitantes do mundo num só ovil. Saiba somente que eles já descobriram a arte de voar, a única que parece faltar ao mundo. Além disso, consideram próxima a descoberta de instrumentos ópticos.

Há muitos e muitos anos, o homem vem pensando nesse adensamento da ciência, mentalizando uma cidade regida pelo conhecimento científico e pelo saber técnico, como em "A Cidade do Sol". As abstrações filosóficas aproximaram a convivência feliz entre os homens em cidade que tivesse como pilar fundamental a cultura do saber científico. À medida que as ciências e as técnicas dominassem a natureza e conhecessem os fundamentos das coisas, a sociedade chegaria ao reino da felicidade.

Essa compreensão, no entanto, tem sido rebatida à luz da realidade. O próprio Morus, citado por Munford (1965:442), revela a contradição das florescentes comunidades e as "práticas perniciosas" na sociedade de classes. Vê-se, no entanto que essa felicidade só se destina a alguns.

Numa sátira dirigida à sociedade inglesa, no século XVIII, "As Viagens de Gulliver" (1726), o irlandês Jonathan Swift também se situa na crítica que, ainda hoje, se apresenta ao desenvolvimento técnico-científico em detrimento da grande massa de excluídos. Numa de suas aventuras, o marinheiro Lemuel Gulliver é lançado por piratas em terras desconhecidas, chegando a um país chamado Laputa, cujos habitantes mantinham atitudes e hábitos estranhos:

Tinham a cabeça inclinada ora para a direita, ora para a esquerda; um dos olhos era voltado para dentro, o outro virava-se para o céu. Seus trajes, esquisitíssimos, mostravam-se 
enfeitados com sóis, luas, estrelas, violinos, flautas, harpas, trombetas, guitarras, cravos e muitos instrumentos musicais totalmente desconhecidos para mim.

"Reparei também em alguns homens de roupas bem mais simples que deviam ser criados: traziam na mão uma espécie de chocalho de cabo longo com que batiam, de vez em quando, na boca ou no ouvido do cavalheiro mais próximo, coisa que absolutamente não consegui entender. Mais tarde me explicaram a razão dessa atitude: os laputianos andam sempre tão distraídos em meditações profundas que não podem falar nem ouvir ninguém se não forem despertados com uma pancadazinha do chocalho na boca ou na orelha. Todas as pessoas que podiam se dar a esse luxo tinham um criado particular encarregado especialmente disso, e nenhum cavalheiro que se prezasse saía sem tal acompanhante.

Também nos olhos dos fidalgos, os criados batiam de vez em quando, pois, entregues a especulações complicadíssimas, aqueles nobres corriam o perigo de se despencarem em qualquer precipício ou se afogarem no primeiro lago encontrado no caminho".

Através de amigos conquistados em Laputa, Gulliver conseguiu visitar o rei. Ao chegar à sala do trono:

"O rei, sentado ante uma mesa repleta de globos, esferas e instrumentos matemáticos de toda espécie, não deu a mínima atenção à minha chegada, embora esta fosse acompanhada de barulhos causados por todas as pessoas da corte. $O$ motivo é que Sua Majestade profundamente mergulhado em seus pensamentos tentava resolver determinado problema.

Vendo o rei com uma expressão ociosa no rosto, os dois pajens que o cercavam finalmente bateram-lhe na boca e nos olhos. O rei estremeceu como alguém subitamente despertado; depois, pronunciou algumas palavras e um dos batedores, colocando-se ao meu lado, deu-me uma leve pancada no ouvido direito com o chocalho. Expliquei por meio de sinais que tal coisa era inteiramente desnecessária para mim, o que, segundo verifiquei depois, fez o rei formar um péssimo conceito de minha inteligência.

Muito hospitaleiro, recomendou também que quatro fidalgos me fizessem companhia à mesa. A refeição originalíssima consistiu de diversos pratos: uma perna de carneiro cortada sob a forma de um triângulo equilátero, um pedaço romboidal de carne de vaca, um pudim cicloidal, depois vieram dois patos em forma de violino, salsichas e pudins que se assemelhavam a oboés e peito de vitela e fora de harpa".

Após outras incursões pelo país, Gulliver divisou a grande Academia da Capital, a cidade de Lagado.

"Possui uma incrivel quantidade de salas tendo eu visitado pelo menos umas quinhentas, e cada qual abriga um projetista e seus ajudantes. O primeiro desses sábios que visitei era magro, tinha cabelos e barba compridas e desgrenhados, mãos sujas e roupa sapecada em vários pontos. Suas calças, camisa e pele eram todas da mesma cor.

Havia oito anos que estudava um projeto para extrair raios de sol dos pepinos.

Um dos sábios que mais me causou espanto era cego de nascença, tendo em volta 
dele vários alunos também cegos. Sua intenção era ensinar-lhes a misturar cores determinadas para a pintura de um quadro gigantesco que pretendia fazer.

Os alunos, que não enxergam coisa alguma, eram orientados pelo mestre a distinguir as diferentes cores pelo tato e o cheiro. O resultado não poderia ser pior. Como o professor também se enganava quase sempre, a confusão era total, sendo ele, apesar disso, muito respeitado e apreciado por toda a fraternidade.

Passei então para outro lado da academia, onde conheci vários projetistas: o que procurava condensar o ar para convertê-lo numa substância seca, o que amaciava o mármore para fazer com ele travesseiros e almofadas, e o que tentava deter o crescimento da lã em cordeirinhos, através da aplicação de gomas, minerais e vegetais, para obter assim uma raça de carneiros pelados.

Confesso que não tive a inteligência de entender para que servia qualquer desses projetos".

\subsection{As cidades científicas no período técnico-científico}

Só depois de um longo tempo, no correr de vários séculos, essas sonhadas cidades das ciências e das técnicas, da educação e do trabalho tornaram-se realidade.

Quais os passos históricos vividos e atravessados pelo homem, para conquistar essa objetividade? Que tempo é o nosso, capaz de soerguer e conviver com lugares inteligentes, lugares privilegiados, antes só projetados pela fantasia? São questões que nos conduzem ao estudo da formação do meio técnico-científico, presente no período do mesmo nome, cujo discernimento encontramos em vários trabalhos de Santos (1985: 1988).

Desde que se ampliaram o transporte e, com ele, o comércio em fins do século XV até nossos dias, cinco períodos históricos se sucederam (Santos, 1985:23):

1) o período do comércio $m$ grande escala (fins do século XV a 1620):

2) o período manufatureiro $(1620-1750)$

3) o período da Revolução Industrial (1750 - 1870)

4) o período industrial $(1870-1945)$

5) o período tecnológico (pós - 1945)

As modernizações ocorrentes no segundo pós-guerra (com as descobertas científicas e aperfeiçoamento tecnológico em todos os campos, com a criação e uso de rápidos meios de transporte, com a utilização da eletrônica nas informações) situam-se, por conseguinte, no quinto dos períodos agora considerados. Essas modernizações conduzem, mais e mais, à formação de um espaço enriquecido com as novas condições materiais e imateriais e uso da ciência no processo produtivo. Assim tem origem o meio técnico-científico informacional, cuja "organização, cuja criação se dá com base na técnica e que não funciona se falta a informação" (Santos, 1993).

As marcas do meio técnico-científico informacional são várias, dentre as quais se distinguem (Santos, 1985): 
“1 ${ }^{\circ}$ ) desenvolvimento da ciência das técnicas ou tecnologia; $2^{\circ}$ ) toda a natureza se torna útil, direta ou indiretamente; $3^{\circ}$ ) circulação do capital à escala mundial $4^{\circ}$ ) Aplicação da ciência ao processo produtivo $5^{\circ}$ ) expansão $e$ predominância do trabalho intelectual $6^{\circ}$ ) aceleração da circulação de bens e pessoas".

Nessa série, o trabalho intelectual toma uma importância significativa na organização e dinâmica da economia, da produção e, por conseguinte, do espaço geográfico. Pela expansão e predomínio do trabalho intelectual, a produção passa a depender cada vez mais do saber, o que conduz à especialização de áreas produtivas, onde se elevam os investimentos de capital constante, amplia-se o setor terciário aumentam os fluxos de bens, informações e pessoas. Os lugares que detêm maior grau de conhecimento dispõem da vantagem comparativa de maior peso na atualidade: a pesquisa.

Dispondo, ainda, de potentes meios de comunicação a longa distância, os centros de pesquisa mais dinâmicos se conectam em rede, retroalimentando-se com as informações. Nesse caso, formam-se pontos, lugares privilegiados de modo disperso no mundo, condizente com a atual mundialização da produção, da técnica e da economia.

Dentre os lugares privilegiados, estão aqueles que respondem às necessidades do momento, a partir de duas possibilidades de integração ao sistema de inovações com o uso de equipamentos tecnológicos e científicos modernos: alto nível de capacitação do trabalho e forte interação entre os elementos do espaço.

Elegemos para nosso estudo alguns desses lugares do meio técnico-cientifico informacional. Com denominações variadas (parques científicos, centros e inovações, pólos tecnológicos, tecnopolos, entre outros) chegam a caracterizar a cidade que o hospeda, como tecnopóle. Os termos mais usuais, presentes na literatura, para designar esse novo tipo de espaço são tecnopolo e tecnópole. Tecnopolo expressa um "espaço bem delimitado com interesse de criar condições ótimas para favorecer a pesquisa e inovação" (Dezert, 1992:209). Para Benko (1991:11), “operacionalmente, é um agrupamento de organizações de pesquisas e negócios que se ligam ao desenvolvimento científico englobando um processo de conjunto, da etapa do laboratório até o da fabricação e da comercialização do produto. Fisicamente, é um conjunto de empresas-escritórios, laboratórios e unidades de fabricação - estruturando num ambiente de qualidade". Assim, essa conceituação demarca o modelo science park ou parque científico, implantado num campus universitário ou próximo dele, comum nos Estados Unidos e na Grã-Bretanha.

Tecnópole, por sua vez, se refere a uma zona de atividade economica dotada da presença de universidades, de institutos de pesquisa, de unidades industriais e terciárias, cujo território é ampliado ao conjunto de serviços urbanos da metrópole. (Couvidat e Giusti, 1991:16)

Esta última noção se centra na conjugação de agentes dispersos numa cidade ou em cidades próximas voltadas a promover inovações e empresas de base tecnológica.

Quere (1987:2) distingue "duas grandes famílias" de tecnopolos: uma, que tende a se aproximar da análise anglo-americana, em que o fenômeno se constitui, mais frequentemente, em torno de um agente privilegiado, a Universidade (science park); outra técnica inscreve a tecnópole como expressão duma vontade de agentes institucionais públicos, o que se aproxima de uma característica mais francesa.

No caso de uma tecnópole, há sempre um núcleo dinâmico, tendo à frente um ou mais centros de pesquisa e outros agentes que catalisam as forças locais para o desenvolvimento técnico-científico. 
Este núcleo tem a expressão de um tecnopolo, o termo mais abrangente para esse tipo de meio técnico-científico informacional.

Quando o suporte técnico-científico e as empresas de base tecnológica duma cidade se adensam num espaço limitado, suas influências locais se irradiam por meios vários, destacando-se as pequenas empresas emergentes que aproveitam as inovações criadas pelos centros de pesquisa.

Ademais, as pesquisas e a transformação destas em bens, processos e serviços nem sempre se enclausuram num "espaço preciso", como em A Cidade do Sol, portanto o tecnopolo, no sentido de distrito industrial marshaliano (Becattin, 1992), é um conjunto de unidades (institutos de pesquisa, empresas, serviços etc.) que se integram e tendem a ampliar a atmosfera e inovação para seu entorno. Em razão de os fenômenos não serem estáticos, essas atividades, em curto espaço de tempo, se ampliam para o meio urbano. Nesse nível, a cidade empresta seu nome ao tecnopolo.

O tecnopolo, portanto, decorre de esforços locais para atingir o desenvolvimento econômico com a valorização do potencial do ensino-pesquisa. Daí a sinergia ou a "fertilização cruzada" necessária entre Universidade, governo e setor empresarial.

No imediato segundo pós-guerra, o tecnopolo é apenas embrião nos Estados Unidos. Nas décadas seguintes, outros centros de pesquisa o adotam. Qual efeito-demonstração, difunde-se por outros países da Europa, Àsia e América Latina. O fenômeno tecnopolitano, no mundo, tem se dado seja em diferentes cidades médias, sob forte patrocínio do poder público, seja em periferia de metrópole em condições pré-estabelecida ou mesmo em "cidades novas", adrede preparadas para esse fim, com a instalação dos equipamentos necessários o aproveitamento dos já existentes em cidades vizinhas. $\mathrm{O}$ fato geral é que todos eles respondem a demandas de um novo período histórico.

Na organização e no funcionamento desses novos espaços uma linguagem específica vem se estabelecendo em variados trabalhos (entre outro, Couvidat e Giusti, 1991; Certaines, 1988; Merlant, 1985), constituindo-se um vocabulário tecnopolitano. Um jornalista diz que o acesso a essa linguagem "joga um papel de filtro. Universitários, prefeitos, conselheiros regionais, empresários ou representantes das Câmaras de comércio e indústria, todo mundo pode achar seu lugar como planejador das zonas de alta tecnologia, na condição de bem dominar os diferentes conceitos”. (Merlant, 1985:20)

- Brain-drain: geralmente traduzido por êxodo de cérebros como a Europa para a América, do sul para o norte, da província para Paris. Propõe-se a criação de tecnopolos como um dos meios para se opor a essa migração.

- Burn-out: os "marginalizados", os excluídos da ciência e do processo, resíduos do catabolismo tecnopolitano, exemplo vivo da sociedade dual.

- Câblage: constituição de uma rede de transmissão de sons e imagens, com o fim de transmitir programas de TV às residências e propor serviços interativos aos particulares e às empresas. O "câmblage" de uma cidade é um elemento de prestígio que conduz uma imagem de marketing favorável ao desenvolvimento de uma tecnópole.

- Capital-de-risco ou Venture capital: financiamento de risco para a criação ou desenvolvimento de empresas de alta tecnologia, susceptível de ser a fundo perdido, mas capaz de originar lucros rápidos e importantes. Esse tipo de financiamento é o que mais propicia o surto de pequenas empresas das áreas tecnopolitanas. 
- Centro de vida, centro de animação: conjunto mais ou menos importante que reúne restaurantes, serviços aos particulares, esportes, lazer... e devendo se constituir um centro de atração e de encontro fora do horário de trabalho, para os tecnopolos e suas famílias...

- Chip (PUCE em francês): é uma partícula de silício com circuitos altamente integrados que revolucionou nosso mundo moderno. "Os chips são o "arroz da indústria", escrevia Moriko Hiramatsu, governador de Oita no Silicon Island (Kumamoto).

- Fertilização Cruzada: expressão criada por Pierre Lafitte, do tecnopolo de SophiaAntipolis, em França. Trata-se de criar energia entre industriais, universitários e pesquisadores para que os trabalhos de uns tirem proveito do trabalho de outros e vice-versa. Assim, a presença num mesmo lugar de universidades, de pesquisa e de indústria é susceptível de provocar inovações tecnológicas e criação de emprego.

- Filière: organização coerente de um setor da pesquisa fundamental à produção industrial sem esquecer a formação. A coerência de uma filière é localmente mais importante que uma simples "massa crítica".

- Gap: lacuna, diferença grande. Fala-se do science gap entre os Estados Unidos e a Europa, ou entre o Norte e o Sul. Fala-se, também, de um gap irredutível entre o engenheiro e o trabalhador sem cultura científica.

- Hardware: a parte "máquina" da informática na qual é aplicada o Soft.

- High-Tech ou alta tecnologia: um tipo de rótulo que se faz necessário atribuir à empresa para fazê-la admitir um tecnopolo. O mesmo rótulo pode servir de argumento publicitário para vender certos gadgets (engenhocas, ferramentas) inúteis a profissionais sobrecarregados: bolsa para avião, despertador que tem na memória o fuso horário de Tóquio, calendário programável. É um conceito muito vago, embora carregado sob todas as formas.

- Hire and Fire: versão anglo-francesa da flexibilidade dos ultras-liberais, o ciclo "empregar-admitir" sem restrição nem preocupação social. Um de seus efeitos é, entretanto, a produção de burn out.

- Incubadora: em inglês: nursery ou incubator; em francês: couveuse, vivier, pépinière d'entreprise: locais e serviços à disposição dos criadores de empresas, tendo por objetivo induzir ao spin-off. Em seguida, durante dois ou três anos, elas se desligm da incubadora para se instalar em lugares próprios.

- Massa crítica: Aceita-se transferir para um conjunto de pessoas intelectualizadas o conceito usado em ciência: quantidade mínima de uma substância físsil necessária para que uma reação em cadeia possa estabelecer-se espontaneamente e manter-se por si mesma.

- Maionese: todo criador de tecnopolo deve usar a maionese: a mostarda é a coletividade loca; a gema do ovo, a pesquisa pública e o azeite, o setor industrial. Como todos sabem, isso não se faz de repente!

- Parque científico: modelo de organização de tecnopolo a partir da tradição anglosaxônica dos campi universitários, frequentemente implantados nas periferias das cidades.

- Parque de Negócios: zona de atividade com predominância do terciário, frequentemente acompanhada de serviços às empresas, sem presença universitária ou de organização e de arquitetura. 
- Rede: compreender simplesmente que a tecnópole não é redutível a uma área geográfica precisa e definida. Seu resultado depende largamente das ligações que ela sabe tecer com o ambiente científico, tecnológico e industrial mais amplo (notadamente à escala regional). A fertilização deve então se operar igualmente através dessas redes. Também podemos dizer que a rede é um: conjunto de agentes, de empresas ou de cidades unidos pelas relações sociais, econômicas ou científicas, no seio de um tecnopolo ou vários tecnopolos.

- Seed Money: financiamento preliminar de um projeto.

- Silicon: material barato, base dos componentes eletrônicos, de que se deriva Silicon Valley (na Califórnia), Silicon Island (no Japão), Silicon Glen (Escócia), Silicon Beach (Flórida), Silicon Moutain (California), Silicon Forest (Oregon).

- Simbiose: associação não conflitual de dois seres viventes, modelo de convívio que deve reinar entre os diversos constituintes do tecnopolos.

- Sinergia: associação que dá resultados superiores à soma de diferentes elementos tomados isoladamente. Em outros termos, a mais-valia da associação. Relações entre empresas e centros de pesquisa ou de empresas entre si.

- Smart Building: imóvel inteligente pré-equipado com cabo. É o tipo de imóvel característico dos tecnopolos modernos.

- Soft: a parte "lógica" da informática. Permite o desenvolvimento de pequenas empresas que exploram melhor a "massa cinzenta" sem grandes investimentos em material.

- Spin-off: em francês, essaimage; exameação, em português: designa o mecanismo pelo qual grandes empresas deixam sair alguns técnicos com o fim de eles criarem seus próprios negócios, se possível complementares da empresa-mãe. Pode-se também falar no caso de pesquisadores que deixam laboratórios para lançar sua empresa.

- Start up: financiamento de uma empresa que se inicia no quadro de capital-de-risco.

- Teleporto: instalações sofisticadas de uma estação de telecomunicações, com imóveis inteligentes, sistemas de rede, equipamentos modernos. Comumente é pólo de atração para as empresas com vocação internacional.

- Tranferência: passagem da pesquisa finalizada às aplicações industriais.

- Triângulo de ouro: os picos deste triângulo não são empregos os mesmos, mas a associação dos três (em geral: pesquisa-formação-emprega) é considerado como a chave do sucesso na criação de uma tecnópole. 


\section{A Reconstrução do Mundo Atual}

\subsection{A grande ruptura e as novas trajetórias}

Ao tratar das questões técnico-científicas nós não podemos esquivar do desenvolvimento com alguns aspectos econômicos, embora de forma resumida, em cujos marcos se encontra o desenvolvimento das ciências e das técnicas. Essas relações intrínsecas conduziram alguns autores tornados clássicos, na formulação da teoria das "ondas ou ciclos longos"

Essa teoria trata dos movimentos oscilatórios da economia que, no âmbito do panorama mundial, se classificam como "ondas ou ciclos longos", com duração entre 50 e 60 anos. A esse fenômeno se dedicara, nos anos 20 desde século, o economista russo Nicolai Kondratieff a quem devemos a formulação dos postulados básicos. O período abrangido pelos estudos de Kondratieff vai do final do século XVII a 1920. Os outros economistas deram continuidade às pesquisas, trazendo até nossos dias a determinação das ondas longos, destacando-se entre estes estudiosos, no Brasil, o Prof. Ignácio Rangel.

Na nomenclatura de Kondratieff, os períodos de expansão correspondem à fase "A" e os períodos de enfraquecimento ou recessão à fase "B". A fase "B" de cada ciclo decorre da quebra e descontrole de interação entre subsistemas tecno-econômico e o sócio institucional. Como o primeiro tem ritmo de crescimento mais rápido, no correr de um certo período de aproximadamente três décadas, há o descompasso, descontrole da quebra do ajustamento com o comportamento social e as instituições que são retardatárias às grandes mudanças. A crise emergente é um grito de alerta desse descompasso. Esse período conhecido como fase "B" das Ondas Longas, caracteriza-se pelo surgimento do conjunto de inovações tecnológicas, e, dado ainda o não uso intensivo e extensivo desse arsenal tecnológico, caem o ritmo e a taxa de produção de mais-valia, bem como o ritmo e o volume de acumulação do capital, fato inerente à baixa produtividade do paradigma tecno-econômico em senilidade.

O ajustamento desses dois subsistemas caracteriza períodos de ascensão - aumento de produção e de difusão tecnológica-, chamada de fase "A" da Onda Longa, com novo paradigma tecno-econômico de duração, mais ou menos, igual à fase $\mathrm{B}$. Os novos arranjos sociais e institucionais circunscrevem-se como a revolução no sistema produtivo, resultante de esforções para sair da fase recessiva.

Aqui é importante lembrar uma das cinco conclusões de Kondratieff: "durante el descenso de las ondas largas, se llevan a cabo muchos importantes descobrimentos e inventos em la técnica de la producción y del tráfico, los que, sin embargo, sólo suelen aplicarse em gran escala e la vida económica práctica cuando comienza um nuevo y persistente ascenso". (Kondratieff, 1 946: 33)

Em ascenso se define como um novo paradigma tecno-econômico que corresponde a "um sistema de inovações interrelacionadas em produtos e processos na área técnica, organizativa e gerencial" (Perez, sem data, p.40), tendo como princípio organizador a dinâmica da estrutura de custos, capaz de levar ao início de nova onda.

Transcorridos dois séculos após a $1^{\text {a }}$ Revolução Industrial, estamos ainda no $4^{\circ}$ ciclo em sua fase 
"B" que se iniciara em 1973, depois de 25 anos de expansão (Rangel, 1990), conhecidos como os "trinta gloriosos" ou período fordista, marca de um modelo de acumulação agora em recessão.

Dentro das normas e da organização desse modelo de acumulação é que os países industrializados, sob a hegemonia dos EUA, restabeleceram as linhas de seu desenvolvimento nas três primeiras décadas do segundo pós-guerra, dando início, portanto, à $4^{\circ}$ onda Kondratieff. Para desenvolver esse percurso de sucesso, o sistema capitalista adotou os norteamentos básicos do taylorismo-fordismo.

A adoção do taylorismo (aproveitamento máximo do Know-how dos operários) ao sistema de máquinas dá o caráter da produção fordista. Com as medidas de racionalização e controle rigoroso do trabalho deriva-se a divisão ou a segmentação das atividads em três níveis de departamento:

- Departamento 1 (D-1), responsável pela concepção dos produtos, organização dos métodos e engenharia;

- Departamento 2 (D-2), local da fabricação qualificada, com uma mão-de-obra adequada e

- Departamento 3 (D-3), loca de execução e montagem desqualificada, não exigindo, em princípio, nenhuma qualificação (Lipietz, 1985-1987).

Esta segmentação se realiza com a divisão espacial do trabalho, expressada na distribuição das unidades de cada Departamento em lugares, regiões ou países, diferentes onde melhores conveniências houver para elevar o lucro. Então, a tendência do sistema de acumulação fordista era globalizar territórios das mais diferentes regiões e países, embora seu centro se mantivesse nos Estados Unidos, na Europa e, depois, no Japão e em alguns outros países. Daí porque as empresas tipicamente fordistas eram as grandes firmas que se capacitariam à produção em massa.

Além dessa divisão interna do trabalho, para mais aperfeiçoar a capacidade operacional dos operários, isto é, propiciando acréscimos na produtividade do trabalho, investe-se em tecnologia, em treinamento, correspondendo assim à incorporação de mais capital constante per capita, com o intuito de elevar a taxa de mais-valia.

Para manter o crescimento do ganho da produtividade, segue-se um acréscimo do poder aquisitivo do operário, através do salário mínimo fixado pelo Estado e um adequado sistema de previdência social; finalmente, para a produção em larga escala, um consumo em massa é necessário. Isso se fez por vários mecanismos: salário direto, salário indireto, pleno emprego, além de concessões pelos bancos, sob regulamentações do Estado, de empréstimos para as famílias e para as empresas. Era o Estado-providência em defesa do mercado interno, seguindo os instrumentos da política keynesiana, posta em execução com o acordo de Bretton Wood logo após o final da II Guerra Mundial.

Esse acordo tinha a finalidade de realinhar a economia mundial e daí reestruturar o sistema produtivo, especialmente ensejando a expansão das multinacionais. Os Estados Unidos, como potência mundial hegemônica, cada vez mais dólares tinham que exportar, fim de manter os planos de reconstrução da Europa e Japão; os empréstimos bilaterais para proporcionar a liquidez ao resto do mundo; as inúmeras bases militares que lhes asseguravam o poderio; e os investimentos das grandes companhias multinacionais. 


\section{a)O débâcle do modelo de acumulação}

Mais para o final da década de 1960, as empresas fordistas não tinham mais condição de elevar a produtividade com aumento dos investimentos de capital fixo, o que imporia acréscimo nos custos de produção. Se mantivessem esse tipo de investimento haveria queda da taxa de lucro.

Quando pareciam acomodadas as condições ótimas de acumulação intensiva do capital, nas três décadas depois da II Guerra Mundial, começa a desmoronar-se a estrutura do regime de acumulação. Isso se dava a partir da desaceleração dos ganhos de produtividades.

Outros fatores vieram, em cadeia, desarticular o regime de acumulação fordista: falência de indústrias, recessão, desemprego, inflação e limitação dos gastos do Estado-Providência.

Enquanto isso, como ressalta um professor da American University, "arrasadas pela guerra, as economias da Europa e do Japão tiraram proveito das dotações de capital público privado, provenientes dos Estados Unidos, para construir fábricas modernas e mais recentes tecnologias" (Wachtel,1988,p.66).

A partir de 1967, demarca Lipietz $(1985,1987)$, os produtos europeus e japoneses entraram em competição com os norte-americanos, invertendo os fluxos de mercadorias, pois a Europa e Japão não precisavam mais importar como antes, dos EUA. "Desde então, a balança comercial americana torna-se deficitária" (p.66).

Com a redução das exportações e da correspondente repatriação dos dólares que se esparramaram, sem controle, pelo mundo, os EUA tiveram que vender parte do estoque de ouro para garantir o sistema Bretton Woods que estabelecia o vínculo entre dólar e ouro e, assim, a moeda americana não entraria em derrocada. Esse pesadelo conclui-se em agosto de 1971, quando Nixon assumiu a Nova Política econômica que estabelecera o controle dos salários e dos preços, reduzira impostos e despesas internas do governo e suspendera a conversabilidade do dólar, criando uma taxa de 10\% sobre as importações, "abrindo caminho para uma real desvalorização do dólar", como dissera H. Kissinger, citado por Wachtel. No início da década, adicionaram-se, ainda, outros fatos que contribuíram para desarticular o processo de acumulação capitalista: a organização dos países exportadores de petróleo - OPEP - e a elevação abrupta do produto, base do complexo industrial que serviria de caput no fordismo: o automobilista.

Para Dolfus (1980) esta crise é estrutural, ou seja, "desaparece o antigo equilíbrio e o novo ainda não é posto". "novo" para o qual ainda continuamos a nos preparar num grande esforço de retomar a produtividade com as inovações, sobre os escombros do velho regime ("destruição criativa" de Schumpeter"), na busca de reedificação de um regime de acumulação que alguns já batizaram de pós-fordista ou flexível.

\subsection{Esboço do regime flexível}

Antes vimos que o descontrole da interação entre os subsistemas tecno-econômico e o sócio-institucional implicava na abertura de uma fase de crise, ou fase B do ciclo Kondratieff.

À medida que ocorrem ajustamentos dos dois subsistemas tende a se definir novo regime de acumulação ou fase A de um outro ciclo. 
Ora, como o arcabouço do regime de acumulação fordista não mais se adequava à realidade emergente, partia-se para novas adequações em que altas taxas de lucro pudessem ser retomadas. Para isso, novos modelos de relações de trabalho e de organização industrial se impunham, tendencialmente fora do âmbito das normas sindicais tradicionais e do próprio Estado (Lipietz e Leborgne, 1988), porquanto decadentes estavam os mecanismos de Welfare State e ante à brusca queda da produção e à grade massa de desempregados.

A internacionalização da produção e da economia, ajudada e impulsionada pelos modernos sistemas de informação e de comunicação, teria facilitado a integração das diferentes unidades das cadeias de mercadorias (economia de escopo), antes desintegradas pela divisão espacial do trabalho. Caminhava-se, nesse roteiro, para o que se tem chamado de flexibilidade, em que entraria, também, novo paradigma industrial, com as recentes inovações tecnológicas.

Embora muitas das inovações tecnológicas, hoje presentes, já tivessem sendo incorporadas pelas empresas dos países desenvolvidos no período fordista, somente com o maior vigor da recessão e de desequilíbrio na economia é que se desperta para intensificar as pesquisas em busca de inovações que propiciassem melhores meios de competitividade.

A avidez por inovações tem sido um comportamento típico das empresas na fase de recessão. Nas empresas, as inovações tecnológicas decorrem de 3 fontes (Aydalot, 1988):

$1^{\text {a) }}$ do próprio processo de trabalho,

$2^{a}$ ) do setor P \& D mantido pela empresa e

$3^{a}$ ) Transferidas das pesquisas realizadas pela Universidades e demais instituições congêneres.

Para a realização das duas primeiras, ocorrem elevados dispêndios nem sempre recompensados nos modelos requeridos pelo lucro. Torna-se mais compensador aos negócios aproximar a empresa ao sistema universitário, orientando-o como economia externa e estimulando-o para que sua pesquisa aplicada se insira no contexto das forças produtivas. Esse papel tem sido bem desempenhado pelas PMEs, como veremos mais adiante.

Com essa inserção da ciência no contexto das linhas de produção, vem se estabelecendo uma rearrumação, tanto no processo de trabalho como nas relações de produção. Sobre a primeira questão, Lipietz e Leborgne (1988) relacionam algumas transformações: no âmbito das relações entre seções, entre estabelecimentos, firmas ou subcontratadas (como controle de estoques, maior aproximação da concepção e fábrica). No quadro individual, diferentes negociações coletivas, polarização das qualificações etc.

Em suma, novo quadro, enfim, começa a se definir no horizonte do que se assinala como pós-fordismo ou flexibilidade.

À proporção de algum setor interno da linha de produção releva uma disfunção, motivada por absorção de inovação tecnológica ou organizacional ou por desnivelamento com os demais setores do processo, esse setor passa a requerer uma reavaliação de sua permanência no novo processo de trabalho ou no modelo de organização da fábrica. Desse modo, muitas atividades estão sendo extirpadas do lay-out do ambiente fabril, exteriorizando-se, quando os cálculos minuciosos da produtividade indicam maior rentabilidade e desenvolver determinada tarefa fora dos umbrais da fábrica, o que se tem 
conhecido como "terceirização". Aqui nascem os "nichos" de mercado, em que se apoia criação de inúmeros pequenos negócios que se desenvolvem tarefas especializadas para as maiores empresas.

Tais tarefas especializadas, muitas vezes, passam a ser executadas por ex-empregados sob forma de trabalho sazonal ou ocasional. Para Scott (1990, esse esquema de economia é caracterizado por uma rede desintegrada de produção com baixo índice de economia interna e açta participação da economia externa, o que estudaremos no item 3.3.

Essa rearrumação interna traduz-se em maiores exigências no trablho: multifuncionalidade de tarefas, variação de horário e de períodos de trabalho, maior qualificação da mão-de-obra, rigorosa obediência às normas e especificações tecnológicas, ao "discurso técnico" no dizer do Prof. Milton Santos. Externamente, com o desemprego, acompanha-se a desarticulação sindical, outra marca do regime de acumulação flexível ou pós-fordista...

\subsection{Adequação do Estado ao novo paradigma}

Tentamos, agora, evidenciar alguns tópicos relativos às funções do Estado, nessas novas condições de transição de regimes de acumulação, em cujo cenário se expandem os tecnopolos.

Por sua força reguladora da vida social e das atividades econômicas, além de principal fonte de recursos para uma grande variedade de investimentos em educação e em $\mathrm{P}$ x D, o Estado não deixa de ser afetado pelas profundas por que passa o mundo nestas últimas duas décadas.

Dadas as exigências, resultantes das transformações do sistema produtivo, que caducaram os códigos disciplinares tradicionais, logo se estabelece a necessidade de regulação para novo tempo.

Nesse sentido, as forças capitalistas têm se esforçado para a conquista das pautas neoliberais, como contraposição ao que perdurava no Estado do bem-estar social, cuja continuidade é reclamada pela sociedade, pelos trabalhadores em particular. Para Souza Neto e Stal (1990), a onda de neoliberalismo associada à Terceira Revolução Industrial tem pressionado a favor da modernização da máquina do Estado.

Embora com a proposta de "menos Estado na Economia" ou o Estado com a mão leve nas regras de mercado, ou grupos econômicos paralelamente não dispensam, no entanto, a outra mão do Estado, de modo firme e pesadamente, na aquiescência de incentivos, de subsídios, de proteção às transações econômicas e de apoio maciço aos meios que impulsionam a revolução técnico-científica.

Com a ajuda dos meios técnico-informacionais, tem sido avassalador avanço dos grandes conglomerados econômicos no domínio mundial, especialmente através de órgãos como o FMI, Banco Mundial, GATT etc, que influem, por sua vez, no âmbito interno de cada país, modificando, de certo modo, as funções corriqueiras do Estado.

Nesse aspecto, Santos (1980) diz-nos que "a noção tradicional do Estado empalidecenas condições político-econômicas do período tecnológico". E explica: "Essa situação é, em grande parte, devido às novas realidades da economia internacional".

Com o enfraquecimento do Estado tradicional, as regulações se orientam no sentido atender as novas exigências dos fluxos internacionais promovidos pelas empresas, especialmente no que concerne à economia e à tecnologia. 
Na compreensão de Petrella (1989: 7 a 10), as relações entre empresa e Estado aparecem sob duas formas:

$1^{\circ}$ ) "as decisões mais significativas decorrem das multinacionais, especialmente no uso dos recursos tecnológicos e econômicos que fazem e refazem o mundo, envolvendo até das Universidades que antes escapavam do mundo dos negócios;

$2^{\circ}$ ) os Estados desempenham um papel secundário, em relação às empresas porquanto eles agem em reação e não antecipação. Nem as empresas, nem os Estados agem sozinho, pois os dois assumem uma dinâmica de aliança nova na mundialização: o Estado é ativo na cena tecnológica e econômica mundial, mas não lidera, sendo ultrapassado pelas empresas que não lhe fazem oposição. $O$ fato novo é sutil: a empresa está se tornando a organização de governo na economia mundial com o apoio do Estado local, cuja função histórica atual é assegurar seus atoresestratégicos (as empresas multinacionais), assegurando para eles a salvaguarda da autonomia tecnológica e econômica.

Assim atuando, o Estado não se afasta dos mecanismos da vida econômica, como pode parecer à primeira vista. Pelo contrário, o Estado se faz muito presente, ainda por outras razões:

I) ele se torna o maior responsável pela penetração das inovações e pela criação de condições de sucesso dos investimentos (Santos). Esse favorecimento do Estado possibilita uma integração crescente das novas tecnologias como os setores da produção, a modernização, das múltiplas atividades (Petrella);

II) “por seus próprios investimentos, o Estado participa de uma divisão de atividade que atribui aos grandes capitais os benefícios maiores e os riscos menores" (Santos, 1980: 179-180). Esse fato é muito bem identificado no que nos referíamos anteriormente, sobre a aproximação das empresas às Universidades públicas, na busca de reduzir os elevados custos de P x D. principalmente com a redução do ciclo de vida dos produtos.

III) o Estado assume importante papel de mercado consumidor em larga escala, o que dá a algumas empresas possibilidade de desenvolver certos produtos que não seriam viáveis para outros mercados, como é o caso da indústria de armamentos e do setor de eletrônica na fase inicial de sua produção;

II) na atual fase de domínio das altas tecnologias, cada vez há necessidade de mão-deobra mais qualificada, resultante de intensos programas de $\mathrm{C} \& \mathrm{~T}$. Elevados investimentos em educação provêm do poder público no sentido de atender ao nível de competividade internacional e

III) noutra instância de função, "o Estado tem que assumir, cada dia de maneira mais clara, seu papel mistificador, como propagador, ou mesmo criador de uma ideologia de modernização, de paz social, de falsas esperanças...”, conforme destaca Milton Santos.

Apesar da retórica de "menos Estado e mais mercado", lembra Ricardo Petrella (1989:17) que "as empresas exigem do Estado essencialmente quatro categorias de apoio e serviços:

$\left.1^{\circ}\right)$ assegurar os custos das infra-estruturas de base (financiamento da pesquisa, financiamento das universidades etc.);

$2^{\circ}$ ) fornecer os necessários os necessários incentivos fiscais para fornecer o investimento em P x D industrial 
e inovação tecnológica;

$3^{\circ}$ ) garantir às empresas do País de base industrial suficientemente estável em lhe oferecendo um acesso privilegiado ao mercado interno e ao mercado público e

$4^{\circ}$ ) apoio e ajuda necessários (do tipo de regulação, diplomático, político etc.) para agir no mercado internacional. Além disso, as empresas reivindicam legislação mais liberal em relação ao mercado de trabalho". Nos últimos anos, vários governos de importantes países têm conduzido sua gestão com fortes tons neo-liberais, detrimento da classe trabalhadora.

Diante do exposto, podemos compreender por que a "proliferação do Estado é uma necessidade e um desejo do imperialismo para sua expansão na fase atual" (Santos, 1980: 180). Esse fato foi patenteado por Henrique Rattner (1989), ao observar que ocorreu a "a criação de mais de uma centena de novos Estados nacionais, no período do pós-guerra".

Permanece o Estado, de qualquer modo, como o principal agente de realinhamento dos subsistemas tecno-econômico e sócio-institucional, além de provedor dos meios materiais para a criação e difusão de invento de equilíbrio mundial ou mesmo em época de recessão.

Referindo-se oo avanço da Revolução Científico-Técnica em um de seus recentes trabalhos, Theotônio do Santos (1993) destaca o forte apoio dos Estados nacionais nas políticas e $\mathrm{C}$ e $\mathrm{T}$ e nas atividades de $\mathrm{P} \times \mathrm{D}$, além da ajuda direta e indireta às inicitivas das empresas junto a centros de pesquisas e universidades.

Por se tratar de uma nova organização em que intercolaboram Empresa x Universidade, o tecnopolo se constitui o canal de excelência em que o Estado investe paramanter as empresa à altura das exigência internacionais. 


\section{Tecnopolos: locus onde germina a inovacão}

\subsection{Agentes indutores}

\section{a) ação do Estado}

Trataremos agora do Estado agente originador e indutor da expansão dos tecnopolos e como parceiro onipresente. Verificamos seu papel em três planos: no primeiro, concernente à atuação corriqueira de manutenção da vida social e econômica; no segundo, como consumidor, ou seja, mercado potencial, e no terceiro, a abrangência de suas diretrizes programáticas, portanto, de planejamento ou de ação mais específica ou direta.

No quadro de agente da manutenção e de reprodução da vida social e econômica, o Estado dispõe de grande conjunto de órgãos nas contexturas nacional, regional e local. Entre esses, no que concerne ao nosso tema, alguns dispõem de poder de financiamento, outro exercem a função de execução e outros, ainda, de planejamento e de regulação. Dado que o surgimento de tecnopolo resulta de um ambiente técnico-científico amadurecido, essas condições derivam-se de múltiplas intervenções do poder público, à medida que novas necessidades são demandadas pelo sistema industrial moderno e pelas coletividades: estruturas básicas, manutenção do sistema de formação e pesquisa e da estrutura urbana.

Respondendo às exigências do sistema produtivo e ao tipo de estrutura social, é que o Estado prepara as condições inerentes à organização tecnopolitana.

Tendo o sistema produtivo local ou regional se tornado cada vez mais complexo, os fluxos de bens, de pessoas e de informação exigem do Estado um arcabouço infra-estrutural capaz de viabilizar o novo modus faciendi: vias de comunicações amplas e potencialmente instaladas com bons terminais, meios de comunicação que atendem à massa de demanda, além de variados tipos de serviços básicos para melhor desempenho da vida econômica. $\mathrm{O}$ espaço urbano não apenas se amplia, mas também se estrutura e reestrutura de maneira a atender às aglomerações que se formam para melhor acomodar os elementos por elas exigidos.

Silicon Valley, nos Estados Unidos, serve como exemplo patente dessa viabilização oferecida pelo Estado para a ampliação dos espaços urbanos, com a supervalorização de glebas tipicamente rurais.

No amplo espectro de investimentos públicos para estruturação do espaço, o Estado transforma-se num potencial consumidor de bens e serviços, além de alocar em sua máquina amplo mercado de trabalho.

Aposto no cenário internacional, o Estado não escapa às pressões das inovações tecnológicas que azeitam a capacidade do funcionamento dos órgãos administrativos, tanto voltado às necessidades domésticas quanto àquelas ligadas ao exterior. Não possuindo os instrumentos de modernização, o Estado se esforça para criá-los ou transferi-los, sem esquecer das injunções da divisão internacional do trabalho que impõem a adesão da sociedade ao sistema produtivo mundial. 
A rapidez das criações e a brevidade do ciclo dos produtos, marca de nossos dias, impulsionaram cada vez mais a máquina estatal na aquisição de novos bens, de novos processos e serviços: ampliam-se as redes de fibras ópticas (espacialmente nos E.U.A), os telefones celulares invadem as metrópoles (mesmo no Terceiro Mundo), moderníssimos arsenais meteorológicos se alocam no campo como exigências das fazendas de criatórios e plantações; o avanço da biotecnologia não só oferece novas descobertas como demanda laboratórios especializados e sofisticados nas cidades e no campo; para a busca do mundo sideral, novos materiais são necessários; mesmo as guerras localizadas já aposentaram as armas convencionais, pois agora as tropas de comando e ação são artefatos computadorizados o que, por certo, levou Galbraith (1969) a observar que o "Departamento de Defesa sustenta o planejamento mais altamente desenvolvido do sistema industrial, com grandes investimentos de capital em áreas de tecnologia avançada" (p.338).

Enfim, os gastos da máquina pública, na paz ou na guerra, se mantêm elevadíssimas na aquisição do moderno, na elaboração do novo, sempre renovando para continuar.

Diferente dos dois campos anteriores, o terceiro é mais programático para a feitura do espaço técnico-científico. Nesse caso, direciona-se o Estado ao desenvolvimento local e regional e, em específico, à vontade política de integrar-se ao circuito do progresso que domina o mundo deste final de século. Embora sem ortodoxia teórica, as políticas voltadas para a instalação de tecnopolos, desde a década passada, valorizam a ideia da indústria industrializante, como referido. O certo é que países como a França e Japão muito se apoiam na condensação de Universidades, laboratórios e indústrias como meios mais eficientes para irradiar inovações e, com estas, proporcionar maior dinamismo regional. Com essa medida, o Estado é o patrono que contribui para sociedade melhor usar recursos disponíveis, aproximando-se da nova realidade mundial, como caminho mais eficiente para sair da crise. Onde já funcionavam centro acadêmicos de expressão, como em França, o Estado se fez parceiro das ações trazendo a si o encargo de elevados investimentos, (na reorganização urbana, com financiamento dos órgãos de apoio envolvidos no novo tipo de espaço.

Nos lugares destituídos de boas universidades, de serviços modernos, de infra-estrutura e do frenesi capitalista, o governo mobiliza todo o seu arsenal de órgãos para atuar de modo imperativo na formulação, o mais rapidamente possível, dos centros de alta tecnologia, como atrativo dos capitais. Assim tem sido no Japão, com o programa Tecnopolis. Um pouco antes, o governo construíra exnihilo a cidade científica de Tsukuba, próxima a Tóquio. Ao Ministério da Indústria e do Comércio Internacional (MITI) ficou o encargo de executar o Programa, no sentido de reforçar a rede de pesquisa em duas dezenas de cidades do País.

$\mathrm{Na}$ Europa, várias iniciativas se efetivaram: em França com os pólos de conversão, esforços de cidades e aglomerações (Rennes-Atalante, Nancy-Brabois etc) e a implantação de unidades de formação e de produção (Sophia-Antipolis); Na Inglaterra, a maior contribuição direta do Estado encontramos nas dotações para Cambridge; na Itália, os recursos sociais financiaram a reorganização da cidade para implantar a Tecnocity.

No Canadá, ou mais precisamente em Otawa, múltiplos equipamentos, de organismos e agências do Estado, deram base para a formação do complexo HT, que aí funciona e por isso tem sido um locus de preferência de inúmeras empresas de vários países (Steed e DeDenova. 1983)

Tem-se notado que o Estado, ao regular os programas de apoio à implantação dos tecnopolos, no 
afã de atender à demanda de tecnologias modernas, incorpora as reivindicações das forças políticas locais e regionais: revitalização da economia local, criação de empregos, melhores condições de moradia, instrumento de desempenho de $\mathrm{P}$ x D. Atendidas essas exigências, criam-se meios adequados para a germinação de spin-offs ou seja, de PMEs como sistema radicular básico para formação do ambiente tecnopolitano.

Guardadas as devidas proporções, nos novos países industrializados esse movimento fora liderado pelas fortes decisões do Estado. Adiante veremos que os polos tecnológicos brasileiros se organizaram sob a tutela estatal. Em Singapura, "a ciência e a tecnologia, os serviços e as indústrias orientadas para a pesquisa são hoje os eixos da política econômica e industrial (Couvidat e Giusti), o que tem atraído fração da burguesia local e capitais externos a investirem nas novas tecnologias (Paix e Petit, 1990) e assim assegurar seu polo técnicocientífico.

Além do Estado, as grandes corporações têm significativo papel no surgimento e expansão dos tecnopolos, pois a aproximação pesquisa-produção lhes asseguraria a manutenção do nível do avanço tecnológico dentro dos parâmetros do atual momento.

\section{b) ação das empresas}

Não é novidade revelar que os grandes avanços tecnológicos da atual Revolução Científico-Tecnológica vulgarizaram-se através das empresas, pelo menos daquelas que detinham "a concentração, monopolização e centralização das atividades de pesquisa e desenvolvimento". Para isso, elas promovem, internamente, profundas mudanças.

No início da fase inicial do atual, os conglomerados norte-americanos tiveram que redefinir suas linhas de produção, realizando, por isso, desinvestimento em certos setores e reinvestindo em outros, para acompanhar a concorrência das pequenas empresas e dos conglomerados japoneses, mais especializados. As grandes firmas escolheram novas áreas pra concentrar seus recursos e intensificar a concorrência, como sucedeu v.g, com a IBM e a AT\&T com o sistema de operação de computadores.

A corrida à competitividade tem elevado significativamente os custos do $\mathrm{P} \times \mathrm{D}$, forçando os concorrentes a se aliar em consórcios a se aproximar dos centros públicos de pesquisas, especialmente às melhores Universidades, na busca de novos processos de bens (Delmas, 1985:208 e Petrella, 1989:11). Aliás, na década de 1960, já dizia (Galbraith, 1969: 359) que "pela sua própria natureza, uma competição tecnológica nunca é resolvida. A segurança depende de manter-se as inovações num alto nível possível, porque existem algumas coisas que são simplesmente caras demais". Dada a ocorrência de elevada sinergia pesquisaindústria, trataremos, simultaneamente, de grande empresa e da universidade, pois para elas converge o conjunto de outras forças que darão dinâmica ao processo.

Merecem destaque duas abordagens no trato da ação da grandes empresas: 1) a inserção da universidade como lógica da reprodução do capital e 2) a internalização pelas empresas das externalidades propiciadas pela divisão social do trabalho.

Malgrado a incorporação da ciência à empresa capitalista venha se dando desde o século XIX (Braverman, 1987), só no segundo pós-guerra, com a Revolução Técnico-Científica, é que essa simbiose origina um sistema espacial chamado tecnopolo.

Isso é dado pelo fato de a ampliação do conhecimento científico depender de condições materiais, 
de instrumentos laboratoriais, de experimentações, ou seja, do conjunto de elementos tecnológicos que têm surgido pela demanda efetiva da comunidade de pesquisadores. A expansão da fronteira das ciências, assim, tem tornado complexa a tecnologia a tal nível que esta se aproxima cada vez mais da Ciência. Isso tem se evidenciado nas últimas décadas, mediante a elasticidade dos campos básicos do conhecimento: na Química, na Física, na Biologia, na Matemática e em suas interrelações de onde decorrem múltiplas invenções e inovações, principalmente nas áreas das novas tecnologias, (Novos Materiais, Biotecnologia, Eletrônica etc.)

Como tem se encurtado o ciclo de vida dos produtos, "as tecnologias estão amadurecendo mais depressa que nunca" (Sbragia, 1992). Com crescente absorção das tecnologias pelo sistema produtivo, este se torna mais e mais dependente do desenvolvimento das pesquisas.

Tratando dos laços cognitivos e da interdependência da ciência e tecnologia, Rodrigues (1992: 635) revela que "quanto mais científica for a tecnologia, mais sensitiva ela se torna às fronteiras da ciência". E acrescenta: "um impacto direto sobre a sociedade é de que o setor produtivo, devido à rapidez e amplitude das mudanças agregados às novas tecnologias, permanece sem condições físicas e humanas de acompanhar tais mudanças. Esta situação torna-o mais dependente da ciência desenvolvida nas Universidades".

Braverman (1987:146) ressalta que "a nova revolução técnico-científica que reabasteceu o acervo de possibilidades tecnológicas tinha um caráter consciente e proposital amplamente ausente na antiga. Em vez da inovação espontânea, indiretamente suscitada pelos processos sociais de produção, vieram o progresso planejado da tecnologia e projeto de produção. Isto foi realizado por meio de transformação da ciência mesma numa mercadoria comprada e vendida como outros implementos e trabalhos de produção. De uma economia externa o conhecimento científico transformou-se num artigo de balanço geral". $\mathrm{O}$ "progresso planejado da tecnologia e o projeto de produção", como marcos da Revolução Técnico-Científica, exigindo maior investimento de tempo e capital, cujo desempenho requer severo imperativo da tecnologia, como enfatiza Galbraith (1969). Isso só é possível com elevado capital fixo (departamento de $\mathrm{P} \times \mathrm{D}$, laboratórios etc), convergência de pessoal altamente qualificado, bem como poder econômico e força política para barganhar mercados e projetos do Estado. São feições próprias das grandes companhias.

O trabalho de Oakey e outros (1980) nos deixa a ideia de que a grande empresa superpõese às Universidades quanto ao número de inovações criadas. Esse estudiosas, numa amostragem de 304 inovações na Grã-Bretanha só encontraram 1,6\% provindas do meio acadêmico. Os dados são mais favoráveis aos centros de P x D das empresas, porque o estudo considera como inovação apenas a "primeira aplicação comercial de uma nova técnica". Isso deixa de lado importantes agentes inovadores que, em muitos casos, são pesquisadores de universidade ou instituições de pesquisas externas à empresa. Aqui entra o complexo debate das patentes.

Não deixamos de reconhecer o significado papel das grandes firmas, mas elas, no período técnico-científico e na fase recessiva do capitalismo, não excluem as externalidades potenciais existentes no meio social, como as universidades de onde saem a força de trabalho qualificada e os resultados de pesquisas de elevado valor, capazes de armar os negócios para o embate que se trava no campo da competitividade e do lucro.

Essa busca pelas regiões com "altos níveis de conhecimento e educação aptas a atrair ou gerar indústrias intensivas em conhecimento e tecnologia avançada" (Steed e DeGeneva, 1983:264) estava 
na estratégia das grandes empresas no quadro das novas formas de competição internacional, ou seja, assegurar-se das novas vantagens competitivas.

As grandes companhias modernas ou "a tecnoestrutura tornou-se profundamente dependentes da classe educacional e científica para sua provisão de potencial humano treinado. Ela precisa também manter uma relação intima com o setor científico daquela classe, a fim de garantir-se de que está seguramente ao lado das inovações coentpificas e tecnológicas"(Galbraith, 1969: 316). É na busca dessa segurança que às portas das renomadas Universidades se enfileiram os empresários ora submetendo-se às orientações dos pesquisadores, ora tornando-se seus parceiros em pesquisa aplicada ou em empresas produtoras de implementos que envolvam alta tecnologia.

Desse modo, em torno das universidades se tem gerado e disseminado um miríade de micro e pequenas empresas comumente voltadas à produção de componentes de base tecnológica orientadas a atender "nichos" de mercado.

Entre os termos e expressões utilizadas para tratar do fenômeno tecnopolitano, o termo inglês spin-off corresponde ao francês essaimage ou enxameação em português, refere-se à propagação dessas pequenas empresas (PMES) criadas por técnicas, engenheiros ou pesquisadores saídos de grandes empresas, ou por cientistas, professores e alunos das instituições de ensino e pesquisa. Em muitos tecnopolos estas pequenas firmas mantêm estreitas relações com as organizações de origem.

Podemos citar, como por exemplo, um caso da América do Norte. De algumas das grandes corporações do tecnopolo de Kanata, a oeste de Otawa, Canadá, gerou-se uma sucessão de spin-off que desencadearam a formação do complexo de alta tecnologia (microcomputador, telecomunicação) dessa região metropolitana do Canadá. (Steed e de DeGenova, 1983).

Com as grandes firmas, as relações das PMEs se dão a nível orgânico ao se engajarem na cadeia produtiva dos setores e com a universidade os contatos se mantêm formal e informalmente. Nesse processo, exterioriza-se a divisão trabalho, especializando-se, a níveis local e regional, o que possibilita a geração de novos negócios e cria zonas de atividades especializadas ou espaços tecno-produtivos.

No estudo dessas vinculações, Gilly (1990) pôde estabelecer conceito de sistema técnicocientífico (STC), ou seja, conjunto das relações que se articulam entre os centros de pesquisa essencialmente público e nas empresas tecnológicas (NET), com capacidade de integrar uma ou mais tecnologias derivadas do corpo de saberes científicos, com o fim de produzir tecnologias genéricas, fontes de inovações tecnológicas".

Através de subcontratações, compra-venda etc, estas inovações tecnológicas das NETs são utilizadas pelas empresas produtoras, dando origem, conforme Gilly, ao espaço tecnoprodutivo (ETP), onde se efetivam, com variadas articulações, as estratégias dos grande grupos que irrigam seu potencial tecnológico com as NETs do STC, ganhando capacidade de inovação e em flexibilidade, ao mesmo tempo que fortalecem a reprodução do STC ou tecnopolos com spin-off.

O Autor dimensiona a potencialidade dos grandes grupos em interconectar diferentes tecnopolos por fluxos informacionais e tecnológicos, o que enriquece os grappes tecnológicos, em articular inovações, organização produtiva e mercados, aproximando os setores e contribuindo para a recomposição das estruturas fordistas, como a introdução de inovações maiores que provocam destruição/criação de capacidades produtivas.

Em suma, os espaços técnico-produtivos, de Gilly, os novos espaços industriais, de Scott, $\mathrm{ou}$ 
tecnopolos têm nas grandes empresas um componente de elevada dinâmica, capaz de impulsionar os demais atores e reestruturar a organização social e espaço

Enfocando a distribuição regional dos estabelecimentos inovadores na Grã-Bretanha, Oakey, Thwaites e Nash (1980) constataram três fatores inerentes à estrutura produtiva que influem no surgimento de inovações:

Setor industrial - a maioria das inovações pode estar concentrada dentro de poucos setores industriais como é, atualmente, o caso das indústrias eletrônicas. A procura sistemática de novas técnicas não é igualmente distribuída por todos os tipos de indústria, porquanto na história da produção industrial encontramos poucos setores liderando de avanço tecnológico.

Entre 287 inovações em 16 setores industriais da Grã-Bretanha (em 1975), 75\% provieram de domínios considerados de alta tecnologia (engenharias mecânica, elétrica, química e de instrumentos e de veículos incluindo aeroespacial) onde os gastos em PxD geralmente são maiores.

Empresa e dimensão da fábrica - embora sabendo que as pequenas empresas sirvam de interface entre a invenção e os protótipos das inovações que entrarão no processo produtivo e nelas ser alta a proporção entre inovações e as despesas em PxD, Galbraith defende a liderança das grandes empresas quanto às inovações. Como defesa das grandes estão seu maior potencial de recursos e habilidade de enfrentar os riscos.

Considerando o número absoluto de fábricas inovadoras, as organizações poli-industriais são dominantes, porquanto $71 \%$ das 287 inovações foram introduzidas pelos grandes estabelecimentos, com número superior a 200 empregados.

Organização - algumas corporações são organizadas em hierarquia ou estruturas, com cada unidade tendo diferentes responsabilidades e complexas funções. A essas funções adiciona a de $\mathrm{PxD}$, criadora de inovação, que numa região favorecerá mudanças.

Quando uma unidade da estrutura dispõe de PxD ela tem conexões com o exterior, passando a ser uma empresa consumidora ou produtora de inovação e geradora de spin-off. Essa funcionalidade é indicada pelo número de trabalhadores não produtivos num lugar, nível marcante apresentado nos tecnopolos, o que reforça as relações das empresas com os centros acadêmicos.

Despertado por esse aspecto é que Jalabert (1990) questiona: “existe um verdadeiro desenvolvimento das zonas HT sem a intervenção direta ou indireta das grandes firmas da eletrônica, da informática, da aeronáutica e do espaço, da bioquímica e bio-farmácia...as únicas capazes de mobilizar os resultados da pesquisa e de realizar o potencial inovante de PMEs e dos laboratórios para desenvolver produtos que atendam o consumo de massa e que ocupam grande parte, as vezes mundiais, dos mercados?"

A literatura específica trata de variados casos em que isso está bem patente. Nos anos 50 , em Palo Alto (Califórnia), partiu o impulso para ativar o mercado de trabalho local. Ligado ao suporte universitário, essa propulsão daria origem à gama de pequenas empresas que viriam surgir posteriormente na região, estruturando um novo mercado de trabalho local. Entre as inúmeras PMEs alocadas no Parque Stanford encontram-se a Hewlett e Packard, Texas instrument, Shockley Semicondutor.

No tecnopolo de Meylan-Grenoble, um dos mais recentes, a ação das grandes empresas marca o caráter dessa zona de inovação, muito bem demostrado por Boisgontier e Bernardy (1985): “As 130 
empresas (inclusive as grandes) da ZIRST sabem pertinentemente que o jogo não é sobreviver sós, isoladas, altivas, mas que é vital inserir-se na rede de relações que conjuga saber produzir ao saber inventar. (p.137). Merli-Gerim (uma das empresas grandes) gerou inovação como um pai de família em implantando duas novas na ZIRST. Quanto à Hewlett-Packard, sua fábrica de Grenoble se interessa por tudo o que se passa no lugar: ela participa da ITMI e prevê outras corporações (p.138). A Thomson se preparava a "purificar-se" (dégraisser) incluindo seu laboratório de pesquisa (p.32). "As raízes desse autodesenvolvimento se deve, sobretudo a utilização das potencialidades do sistema pesquisa científica e tecnológica por todo um conjunto polimórfico de jovens profissionais hiperqualificados desiludidos das condições de trabalho das grandes empresas privadas..." (p.35).

Da Sens, que participa do grupo Bull, derivam-se 19 empresas na ZIRSTde Meylan.

$\mathrm{Na}$ Itália, dois casos entram na galeria de tecnopolos, marcados pela decisão direta de grandes grupos:

$1^{\circ}$ ) o de Bicocca, próximo a Milão, tem no grupo Pirelli seu principal patrono, que em 1987 criou uma sociedade encarregada da gestão técnico-administrativa para por a cidade de Milão na vanguarda do ponto de vista econômico, científico e urbanístico" (Couvidat e Giusti,1991)

$2^{\circ}$ ) e o de Turim, que devido à severa crise dos anos 70 , sofreu um grande abalo, em especial na indústria automobilística, demostrando toda um estrutura fordista e reconstruindo um novo modelo, um verdadeiro processo de "desindustrialização/reindustrialização". Desse fato nasceu o projeto Tecnocity, da fundação Agnelli, que acentuava, conforme Dianni (1985), os recursos sob-utilizados a serem reativados:

- o papel e importância de universidades tecnológicas, de centros de pesquisa públicos e privados;

- a existência de 3 polos industriais especializados na Informática, na Mecânica avançada e na integração da Mecânica e da Eletrônica, e

- a forte concentração de robôs industriais e de lasers, sem igual na Europa". (p.124-5)

Outros autores (Biondi e Coppola, 1985), a par da avaliação dos science parks na Itália, relatam que "o Tecnocity" é um projeto que se baseara sobretudo no papel de protagonista dos empresários privados e das instituições financeiras. Fala-se de um modelo privado especializado (e trata-se sobretudo de grandes grupos, tais como FIAT e Olivetti) que devem assegurar a produção e a circulação da inovação na operação”. (p.157-8)

Poderíamos nos remeter a outros recantos do mundo. Verificaríamos, certamente, que na essência da vocação tecnopolitana do lugar, uma grande empresa, um ente com capacidade potencial para gerar spin-off e um amplo mercado de trabalho, estaria impregnando o meio ambiente e criando as condições inerentes à sua retro-alimentação: assim aconteceu com a IBM no Triangle Research Park (Carolina do Norte, EUA), ou no Innopole, em Labège (Toulose, Fr) com a MATRA.

Para viabilizar a retro-alimentação dos grandes negócios, necessário tem sido o apoio financeiro às novas pequenas empresas inovadoras, através de organizações especializadas em capital de risco, de que trataremos a seguir. 


\section{c) O capital de risco.}

Vimos que as grandes firmas, com o fim de viabilizar as exigências do tempo atual, fizeram a inserção da Universidade de forma direta, com os contratos de pesquisa e estudo: ou de forma indireta, com a utilização dos produtos criados pelas micro e pequenas empresas especializadas, emergentes dos departamentos de pesquisa e engenharia.

A favor da geração desses empreendimentos, medias têm sido tomadas pelos órgãos públicos de diferentes países, entre as quais a formulação de apoio, estímulo e orientação com regulação e incentivos à concessão de capital de risco por instituições públicas ou sociedades privadas, como apoio a inovação tecnológica das empresas. As exigências financeiras conjugam-se aos componentes do espaço técnico-produtivo.

Entende-se, aqui, como investimento de risco os capitais destinados a desenvolver pequenas empresas especializadas na área das novas tecnologias, procurando oferecer competência, estratégia comercial, organização e gestão.

Com a ampliação das novas tecnologias e sua absorção pelos negócios nos países, onde a presença dos tecnopolos se faz em maior número, são encontradas instituições financeiras altamente competentes neste tipo de investimento, conforme Souza Neto e Stal (1990).

Nos Estado Unidos, os investimentos começam nos anos 30, com a Grande Depressão, dando assistência às PMEs, através da Reconstruction Finance Corporation (RFC) que se estrutura em 1946 para formar a American Research and Development Corporation (ARD) - a primeira venture capital company (VCC).

Dos anos 50 em diante, ocorre uma série de regulações, programas, formação de firmas especializadas em capital de risco e atividades congêneres, que reforça p desenvolvimento tecnológico avançado.

Na Grã-Bretanha, a motivação assentava-se na proteção à pequena empresa. A primeira instituição a prover capital de risco e uma série de serviços correlatos foi criada em 1948: a National Research and Development Corporation - NRDC. Outras sociedades foram sendo criadas, especialmente foram sendo criadas, especialmente nos anos 70 e 80 .

A França criou em 1955 a Sociétés de Développement Régional (SDR) e, nos anos 70, a Sociétés Financières D'Innovation (SFI) e Instituts Régionaux de Participation (IRP). Na década de 80, o governo estabelece dispositivos regulamentares do poder público para o capital de risco, a partir do que são criados outros negócios no ramo. O governo dispõe da Agência Nacional para a Valorização da Pesquisa. Na Alemanha uma associação de 27 bancos forma a wagnisfinanzierung-Gersellschaft, destinado ao financiamento de risco. $\mathrm{Na}$ Europa, como nos Estados Unidos, as novas tecnologias absorvem a boa parte desse tipo de investimento, e, por isso, o Estado procura garantir perdas eventuais dos bancos e incentivar a criação de sociedades de investimentos (Solomon, 1989). Entre 1981 e 1987 quatro setores ligados à alta tecnóloga nos EUA absorveram de 55 a 74\% dos investimentos totais.

Para Jalabert (1990), a variação do comportamento das sociedades de capital de risco denota as diferenciações entre os países ou entre as regiões e, por conseguinte, revela a gradação do movimento tecnopolitano. No caso dos EUA, a maior presença de investimentos de risco para empresa de alta tecnologia $-67 \%$ do total nacional- se concentra nos Estados da Califórnia, Nova Iorque e Massachusetts, 
onde se encontram as mais importantes universidades. Tem-se verificado (Benko, 1991) que o investidor de capital de risco, diferentemente dos demais financiadores, quase sempre pratica uma gestão hand on, o que exige proximidade geográfica com a empresa nascente, a fim de colaborar com os demais parceiros valorizar a empresa e procurar contratos comerciais e financiamentos complementares.

Souza Neto e Sal (1990) caracterizam estes operadores como "ativos", ou seja, "promovem ligações entre vários instituições, formando uma rede com organismos financeiros, grandes empresas, Universidades e empreendedores, agindo como technological gatekeepers e acelerando o processo de mudança tecnológica.

Ademais, a presença do investidor no local da empresa lhe possibilita maior envolvimento com a vida industrial, técnica, científica, financeira e comercial da região. Esse comportamento e a presença do investidor no local aumenta a sinergia entre os agentes envolvidos e fortalece o capital de risco como fator locacional dos empreendimentos de alta tecnologia, tornando-se, assim um promotor de desenvolvimento regional.

Subjacentes ao capital financeiro estão as condições instrumentais do lugar, como infraestrutura de comunicações e de atividades de pesquisa e desenvolvimento.

\subsection{As bases da eficiência tecnopolitana}

\section{a) Universidade, Institutos de pesquisa e laboratórios}

As forças produtivas hoje dependem, em maior grau, do conhecimento científicotecnológico, de modo que os centros de pesquisas pesam muito mais na organização da produção. Isso se dá não apenas para a produção, como também para a renovação constante do próprio saber, o que refina a intensidade dos liames entre pesquisa básica e pesquisa aplicada. Essas condições se afinam com maior eficiência no âmbito das Universidades, Institutos de Pesquisa e Laboratórios.

A agregação das atividades dos institutos de pesquisa, laboratório públicos e privados, centros de transferência de tecnologia e universidade origina o que se tem conhecido como pesquisa e desenvolvimento $(\mathrm{P} \times \mathrm{D})$. Seu adensamento resulta de fatores variados: aglomerações urbana, qualidade de vida, mercado financeiro, dinâmica econômica e estímulos governamentais, (Malecki, 1981). Notamos que esses recursos se concentram em poucas áreas do mundo.

Em um de seus trabalhos sobre os EUA, Malecki (1980) pôde constatar que "P x D é mais concentrado que a população e a atividade industrial, tomando por referência vários elementos: laboratórios de empresas, faculdades e universidades, cientistas e engenheiros engajados e emprego governamental". Em referência aos EUA, em 1976, em apenas 20 áreas metropolitanas estão 70 Universidades que operacionalizam 52,2\% do total de P x D do País, embora essas áreas contenham somente $33,9 \%$ da população nacional.

No entanto, conforme o mesmo Autor, a influência da Universidade atinge um raio de $300 \mathrm{~km}$, mantendo-se como primeira causa da concentração de $\mathrm{P}$ x D, com vários resultados, entre os quais pessoal altamente qualificado, consultores, pesquisa direta e indireta.

Em razão da sua maior presença nas grandes aglomerações urbanas, esses componentes da atual 
modernidade assumem um caráter de indutor da organização do espaço geográfico, não só pela força endógena deles resultante (multiplicação das pesquisas, atração de recursos humanos etc), quanto pela representação simbólica construtora de imagem de atração de firmes de alta tecnologia e valorização de espaço.

Daí Galbraith (1969) dizer: "Hoje se exibe o nome de um cientista ou, pelo menos, de um diretor de faculdade, (...) para mostrar que a firma está afinada com o que há de mais recente em avanço tecnológico", (p.313), porquanto, ainda afirma o ilustre autor da A Era da Incerteza, "a tecnoestrutura tornou-se profundamente dependente da classe educacional e científica para sua provisão de potencial humano trainado. Ela precisa também manter uma relação íntima com o setor daquele classe, a fim de garantir-se de que está seguramente ao lado ao lado das inovações científicas e tecnológicas" (p.316).

Em relação, especificamente, à Universidade, em cuja estrutura está o conjunto de laboratórios e de pessoal altamente qualificado e em formação, ela se destaca entre as causas de impulsão dos tecnopolos, do qual é parte integrante.

Assumem, os centros universitários a base principal do tecnopolo (Manzagol, 1990), quer na construção de science parks, quer na indução de centros polarizados de desenvolvimento econômico a partir da dinamização de algum domínio tecnológico.

Reconhecemos, com Scott e Storper (1988), terem essas instituições de ensino um papel significativo na formação apropriada da força-de-trabalho e na e na descoberta de processo e bens inovantes dirigidos ao sistema industrial local e regional. Além do mais, conforme os Autores, "quando estas instalações são fornecidas ou subsidiadas pelo poder público, os fabricantes têm a vantagem da desprivatização de pelo menos parte dos custos do treinamento, pesquisa básica e desenvolvimento" (p.38). Essa desprivatização é umas das mudanças organizacionais e técnicas que podem servir de minimização das deseconomias de aglomeração para alguns complexos industriais. Este fato tem contribuído para o surgimento de tecnopolo em áreas decadentes da industrialização tradicional, o que Certaines (1988) denomida de les pôles de reconversion, tais como o Technocity (Turim), Nancy Brabois, Metz 2000, ZIRST de Meylan (Grenoble) a Rodovia 128 em Massachusetts, os tecnopolos escoceses etc.

Outra vertente enriquecida pelas instituições educacionais, mostrada por Scott (1988) é o "processo geral da reprodução social de acordo com as necessidades dominantes e tendência do mercado de trabalho" (p.40), para os quais bem se ajustam os programas de ensino e pesquisa, como se pode testemunhar desde a Universidade de Stanford até os casos mais recentes de organização tecnopolitana.

$\mathrm{Na}$ fase recente da desindustrialização de tradicionais regiões manufatureiras, na tentativa de acompanhar o processo concorrencial do mundo moderno, nos esforços de descentralizar os recursos sócios-econômicos e de $\mathrm{P}$ x D ou para responder necessidades estratégias ou, ainda, em busca da tomada de ações desenvolvimentistas, os mais diferentes países do mundo têm encontrado nas Universidades um reservatório de invenções e inovações, além de respostas adequadas para a questões técnico-científicas do momento. Ante às novas relações de produção, cada vez mais a Universidade se inclui como fator destacado da dinâmica econômica. Não é fora de propósito a reportagem de John Elson (TIME, 13/04/92), Campus of Future, onde ele se escreve que "para justificar sua existência como útil à sociedade, todas as escolas sofrerão pressão para ser menos teóricas e mais práticas..."

Nessa trilha encontramos a centenária Universidade de Stanford com seu Industrial Park, fundado no início dos anos 50 pelo Prof. F. Terman, em Palo Alto, na California, EUA. Nessa nascera a eletrônica 
na segunda década deste século e de onde brotariam empresas ligadas à microeletrônica apoiadas pelas pesquisas e pela elevada demanda de interesses militares dos EUA. Ainda na atualidade, as universidades californianas mantêm o alto nível de pesquisas básicas e aplicadas no mundo HT.

Embora Dorfman (1983) revele que "a emergência da Rota 128 de Boston não foi propiciado pelo governo, nem pela universidade", o mesmo Autor não exclui a atividade acadêmica da Universidade de Boston e do MIT (Massachusetts Institute of Technology) e de dezenas de outras instituições de ensino e pesquisa da região metropolitana de Boston, no desempenho técnico-científico de reversão econômica que teve o Nordeste do EUA a partir do anos 70, com os setores das novas tecnologias. Muitos dos empresários, a quem Dorfman credita o revigoramento da região, provieram da Universidade e de laboratórios locais que contribuíram para muitas das inovações transferidas para o sistema produtivo. Destaca-se a participação efetiva de vários laboratórios do MIT (Draper Instrumentation, Cruft, Artificial Intelligence etc.), não apenas sendo úteis em transferência de tecnologias, também funcionando como spin-off de firmas que enriqueceram o complexo industrial da região.

Com o passar dos anos, a "febre tecnopolitana" se volta parao sunbelt. No Arizona organiza-se um complexo tecnológico em Phoenix (Manzagol, 1990). Atuam, nesse caso, a Faculdade de Ciências Aplicadas e o Centro de Engenharia de Alto Nível. A Universidade do Estado do Arizona criou um parque científico de 140 há, dando mais ênfase à biotecnologia, visto que o potencial econômico financeiro tem sua base na atividade do setor primário. À poderosa Motorola, que dispunha de laboratórios próprios, e outras firmas do ramo das comunicações, ficava o filão do mercado militar que, desde 1942, assentara seus quartéis nas proximidades de Phoenix.

São variados os casos em que a Universidade se tem destacado na construção dos inúmeros espaços tecnopolitanos nos EUA, nessas cinco décadas do segundo pós-guerra (ver p.83).

$\mathrm{Na}$ Europa, no entanto, a política de inovação ou política de $\mathrm{C}$ e $\mathrm{T}$ é mais recente (Salomon, 1989); no contexto de seu incremento, se desenvolvem os tecnopolos. Para Certaines (1988), os tecnopolos se ampliam no sentindo de uma "operação de salvamento de regiões sinistradas": Tecnocity em Turim, Nancy-Brabois e Metz 2000 na Lorena; ou, "noutra variante, fruto de uma crise menos aguda, se apóiam na valorização de um potencial preexistente, mais frequentemente universitário: Ideon, na Suécia, Cambridge, na GrãBretanha, Louvain-la-Neuve, na Bélgica, Rennes - Atalante ou Montpellier, na França".

Saloman (1989) considera que essa onda resulta de três evoluções " 1 a) reflexão econômica e sociológica sobre os fatores determinantes da competitividade das empresas e o papel das inovações técnicas; $2^{\mathrm{a}}$ ) atividades econômicas advindas da crise do petróleo (depois dos "trinta gloriosos" e $3^{\text {a }) ~ s u r g i m e n t o ~ d e ~ n o v a s ~ t e c n o l o g i a s . ~ N a ~ E u r o p a, ~ d e s d e ~ o s ~ a n o s ~ 60, ~}$ muitos países se inquietaram em acompanhar os programas estratégicos nucleares, aeroespaciais e de telecomunicações dos EUA. Estudos conduzidos por diferentes instituições convergem para uma conclusão: "o problema da inovação não está nos investimentos $\mathrm{P}$ x D, mas na gestão das estruturas universitárias e industriais fundadas no modelo do empreendedor".

Vendo os limites das políticas de $\mathrm{C}$ e $\mathrm{T}$, a Europa "adotou um novo modelo que engloba a educação, a pesquisa, a indústria e o comércio exterior, para assegurar o dinamismo das empresas no plano mundial".

Os tecnopolos europeus são resultantes desse novo modelo, no que concerne às ligações mais estreitas entre a Universidade-indústria, dando como produto, além da formação de mãode-obra qualificada, as pesquisas e PMEs criadas por pesquisadores e engenheiros, com apoio do 
Estado e uma forte rede de externalidades à disposição do tecido industrial em suas diferentes escalas. Essa linha é reforçada, mais ainda, pelo Programa FAST (Forecasting Analysis for Science and Technology) da CEE que confirma ser no "terreno da educação, da reciclagem das competências e da formação profissional que se joga mais certamente a batalha da competitividade".

Há uma multiplicidade de tipos de organização tecnopolitana por toda a Europa, o que vem definir não só as diferentes relações com a Universidade, como também a própria variação de estrutura acadêmica.

As iniciativas pioneiras dos EUA inspiram os europeus para o movimento dos tecnopolos, iniciando-se no extremo-sudeste da França, com Sophia Antipolis, "a cidade da sabedoria, das ciências e das técnicas", antevisão de um professor da Escola de Minas de Paris, Pierre Lafitte. A idéia agregou escolas de nível médio e de nível superior, centros de pesquisa públicos e privados, situados em cidades próximas, destacando-se o Instituto Superior de Informática e de Automação (ISIA), Escola Superior das Ciências e Tecnologias de Engenheiro de Nancy (ESSTIN), Instituto Nacional de Pesquisa Agronômico (INRA), Centro de Ensino e de Pesquisa Aplicada à Administração (CERAM) e, em destaque a Universidade de Nice-Sophia Antipolis. Um dos dirigentes desta Universidade ressalta que nela funciona "o único curso de farmacologia para o magistério e uma das poucas com o doutorado nessa área e estreitamente associado ao mundo empresarial". (Lazdunski, 1990:17).

Cidades e regiões várias do país seguiram as experiências de Côte d'Azur. Alguns desses recantos com Universidades portentosas e centros de pesquisa e formação dispersos em sua região adicionaram esforços de seus líderes para a implantação de instituições de pesquisas e formação no intuito de atrair empresas e pessoal de alto nível de conhecimento, ou ainda, retomar o dinamismo econômico em crise.

Grenoble teve o Instituto Nacional Politécnico - INPG (com sete escolas de engenharia e 24 laboratórios de pesquisa) e no Centro Eletronuclear o esteio para criar a Zona para Inovação e Realizações Científicas e Técnicas (ZIRST), em Meylan.

Lyon, Toulouse, Montpellier, Villeneuve, Orléans, Marselha e Bordeaux servem de exemplos franceses em que a Universidade desempenha um papel fundamental na chamada "fertilização cruzada".

Em relato publicado em 1989, o Prof. Sternberg, da Universidade de Hanover constata que na Alemanha "os centros de inovação (CIs) tem se tornado um instrumento de política de inovação e desenvolvimento econômico local, desde o início dos anos 80". No final da referida década, a RFA contava com CIs em operação e outros 50 em construção, espalhados nas regiões Norte Reno-Westfália, Baixa Saxônica e Baden- Wutemberg. Baviera e Hessen. Em enquete aplicada junto às empresas do CIs pelo Prof. Sternberg, pôde-se verificar que dentre as 10 vantagens oferecidas pelos CIs, só as de caráter mais imediato (redução de taxas, contrato com outras firmas e fácil crédito) superaram aquelas relativas ao convívio com as instituições de ensino e pesquisa (imagem acentuada do local, consultoria, contatos com P x D). Em Berlim, situam-se o Centro de Inovação e de empresas (BIC) e o Parque de Tecnologia e Inovação (TIP) que recebem apoio de toda a Universidade Técnica de Berlim (UTB) com vasto número de institutos de estudos aplicados em físico-química, informática, tecnologia de materiais etc. Além da UTB, o BIC e o TIP têm vinculações no campo da tecnologia médica da Free University; do Heinrich Hertz Institute, especializados em robô e automação industrial, e muitos outros. 
Em face dos serviços oferecidos, no campo da transferência de tecnologia, consultoria, pesquisas e formação de pessoal das várias instituições berlinenses têm surgido outros institutos e PMEs. O que na Alemanha se conhece como CI, na Grã-Bretanha chama-se science parks. Conforme a United Kingdom Science Park Association -UKSPA-, até 1988 havia na Grã-Bretanha 38 science parks, $87 \%$ dos quais instalados a partir de 1984 . Neles estão envolvidos 28 universidades, destacando-se:

- Universidade Heirot-Watt (UHW) cujo campus, atualmente, situa-se a $2 \mathrm{~km}$ dos limites de Edimburgo, numa área de 90 ha, 20 dos quais ocupados pelo Parque da Pesquisa onde se assentavam em 1988 cerca de 33 organizações originadas de três fontes: as geradas pela Universidade, companhias externas e Grupo de Transferência de Tecnologia - GTT.

- Trinity College Cambridge - formado em 1972 numa área de 52,6 ha, o Cambridge Science Park, (o maior da Grã-Bretanha) tem sido atrativo pelo renome da Universidade e pelo agradável ambiente da cidade histórica.

- Universidade de Aston. Seu parque - Aston Science Park - foi estabelecido em 1983 com o propósito de reconverção econômica. A Universidade de Aston pe uma das primeiras universidades tecnológicas da Grã-Bretanha.

- Birmingham conta com duas universidades e uma escola politécnica, registrando colaborações bem sucedidas com a indústria e comércio, particularmente na Engenharia, Ciência, Medicina e Gerenciamento. Em 1986 foi aberta a University of Birmingham Research Park, com número superior a cinquenta empresas.

- Brunel University (BU), em Uxbridge, no Noroeste da Grande Londres, desenvolve atividades de pesquisa e formação nos campos das ciências, da tecnologia, engenharia, e ciência social, dando ênfase em sua aplicação prática, nas indústrias e no comércio. Para incrementar essas relações e oferecer maior apoio às empresas, foi criado o Brunel University Science Park, em 1986, com 22 firmas locatórias.

A university of Surrey tem seu campus na cidade de Guildford, com 60.000 habitantes, onde funcionam Faculdades de estudos humanos e vários institutos de engenharias e um centro de tecnologia de excelência, orientando para as interações universidade e indústria. Em 1984,em 28,4 ha. do Campus foi aberto o The Research Park University of Surrey que, em 1988, já contava com 43 locatários.

$\mathrm{Na}$ Itália, o destaque fica por conta da Tecnocity, em Turim, quando a indústria local, a FIAT em particular, se viu dominada pela crise dos anos 70, recorreu aos centros acadêmicos, aos institutos de pesquisa, cadinhos de ideias, de inovações e de possibilidades a oferecer, sob baixo custo, para a retomada do crescimento tecnológico e econômico.

Em interessante trabalho sobre esse tecnopolo, Jalabart e Gregois (198) fazem notar que "um dos objetivos do Tecnocity é de reaproximar aparelho de formação e tecido industrial", para o que a Fundação Agnelli (FIAT) patrocinou um estudo que revelava "a necessidade de reforçar as ligações entre indústrias locais e aparelho de pesquisa universitária científico". Ainda mais, nesse campo, criou-se um instituto para desenvolver pesquisas e estabelecer com o MIT e Princeton, EUA, e contratar pesquisadores, em domínios científicos não avançados em Turim.

No Extremo-Oriente, é no Japão que se concentra os recursos de P x D. Nesse País, o adensamento maior esta a se efetivar com a construção da cidade científica de Tsukuba, a 60 $\mathrm{km}$ da capital, para 
onde foram 47 instituições de pesquisa e educação, para atender a um futuro parque industrual cuja área fora reservada no distrito suburbano (ver p. 112-114).

Só nos anos 80 o governo decide levar adiante o Programa Tecnopolis, inicialmente para 14 localidades. Concordando com o programa, a cidade teria que atender a alguns critérios, dentre os quais vocação industrial, e manter uma universidade capaz de relacionar-se com o setor produtivo no que se refere à assistência técnica, formação de pessoal, acesso da indústria a seus laboratórios e demais serviços etc.

Em alguns tecnopolos, as pesquisas se dinamizam mais nos laboratórios das próprias empresas, pois no Japão a indústria financia $75 \%$ das pesquisas (Technopolis, Autrement, $\mathrm{n}^{\mathrm{o}}$ 74, nov. 1985, p.86).

Em Taiwan, a concepção do parque científico também se fez presente, na cidade de Hsinchu, nos anos 80, depois de já ter conquistado espaço no mercado mundial. Dentre outros fatores conjunturais a favo do projeto, destaca-se a oferta de mão-de-obra competente a custo mais baixo que nos EUA. Para ter essa reserva de mão-de-obra, Taiwan forma, por ano, em média, 25.000 engenheiros e cientistas. Uma Universidade e um Instituto de Pesquisa em Tecnologias Industriais (ITRI) e um centro nacional de instrumentos de precisam participam da pesquisa aplicada e da transferência para a indústria em cinco setores: Química, Mecânica, Eletrônica e materiais, mantendo fortes vínculos com o meio técnico-científico dos EUA.

Nos países do Terceiro Mundo, a criação de tecnopolos tem sido feita a partir de incentivos de setores governamentais, dentro da política de exportação e de $\mathrm{C}$ e $\mathrm{T}$. Especificamente no Brasil, o CNPq tem, desde a metade dos ano 80, dirigido esforços para a implantação deste mecanismo onde pré-existem condições de mercado, desempenho acadêmico e vontade sócia e política.

Em torno das Universidade Federais de Santa Catarina, de São Carlos, da Paraíba etc., e das universidades paulistas, a institucionalização de pólos tecnológicos envolveu professores técnicos a alunos universitários e empresários. Nesses pólos tem aumentad a formação de firmas de base tecnológica, resultantes de transferência do conhecimento acadêmico, o que vem desempenhando novo dinamismo econômico nessas "ilhas de competência" do País.

\section{b) Infra-estrutura de comunicação}

A fragmentação da produção, com os consequentes núcleos especializados e a necessária articulação inter-empresarial, além dos contatos permanentes com mercados, exigem maoir capacitação das redes de comunicação. Essas redes possibilitam a interconexão e complementaridade contínua entre os variados centros, necessários a nova formas de produção mundial. Essa é uma condição básica para a eficiência dos tecnopolos, seja no japão, na Europa ou em outros continentes.

Ao estabelecer, no início da década de 80 , seu plano de tecnopolos, o Japão da dava continuidade à política de desenvolvimento regional que se iniciara com a Lei Nacional de Desenvolvimento da Terra, nos anos 50. Esse plano selecionou duas dezenas de cidades para recer o tecnopolo, a partir de critérios demográficos (aglomerados que contassem mais de 150.000 hab.), além de apresentar eficientes meios de transporte, isto é, proximidade a aeroporto a ser servido por ferrovia (Glasmeier, 1988).

Em 1969, fora implantado o trem-bala (shinkansen), como forte incentivo à permanência dos negócios nas regiões beneficiadas. Em 1985, o MITI e o Ministério dos Correios e telecomunicações 
criaram o Centro de Tecnologia chave, para financiar pesquisas na áreas do sistema de informação e comunicação, entre outros. Para a implantação da cidade científica de Tsukuba, a $60 \mathrm{~km}$ de Tóquio, o governo construiu a moderníssima rodovia Joban, além de outras vias na região.

No marketing de promoção do tecnopolos europeus se destaca a divulgação da macrolocalização, tendo as isócronas como uma das bases para atrair a implantação de empresas e de pessoas, como apelos de destacada promoção. Em Sophia-Antipolis (S.A)procura-se ressaltar que "a montanha está a uma hora de rodovia", assim como a relevância em firmar que esse primeiro tecnopolo europeu está situado ao longo da auto-estrada A-8 e próximo às grandes aglomerações da Côte d'Azur: Nice $(22 \mathrm{~km})$, Antibes $(8 \mathrm{~km})$, Cannes $(15$ $\mathrm{km})$ e Grasse $(16 \mathrm{~km})$. No "Le Journal Shophia-Antipolis", em inglês e francês, lemos: "Sophia-Antipolis beneficia-se de um sistema de telecomunicações evoluído capaz de favorecer, por sua vez, a informação e o diálogo entre pesquisadores, professores e industriais instalados no parque, como também as trocas com seus parceiros franceses e estrangeiros, que se trate de transmissão de voz, das imagens e dos dados". S.A tem, na França, uma das primeiras Zonas de Telecomunicações Avançadas”, ZTA.

Quer tratando-se do tecnopolo de Cambridge, de Bordeaux, de Louvain-La-Neuve, de Nantes, de Montpellier ou de Toulouse procura-se sublinhar os modernos meios e vias de comunicação como elementos virtuais de sua localização, o que também entra no marketing desse pólo.

Não se trata aqui de discutir o transporte no corpo da teria clássica da localização da atividade econômica, mas demonstrar o papel desempenhado pelos modernos meios de comunicação no destaque e funcionamento dos tecnopolos.

Não desprezando a importância dos serviços de transporte em comum-sistema aéreo, rodoviário, ferroviário- as empresas, dia a dia, estão mais atentas à eficiência das telecomunicações no que elas podem fornecer e nas soluções mais econômicas, dada a utilização que delas se faz atualmente em vários aspectos do cotidiano, verificado com os avanços da eletrônica que tem sido o centro do progresso dos demais ramos do conhecimento. Para isto, o instrumento básico é o que se chama de teleporto, em alguns casos configurandose como tecnopolo, em outros tornando-se apenas um suporte deste (Briole e Lauraire, 1990).

Bakis (1987) relaciona os três elementos do teleporto:

1) Uma estação central de emissão e recepção de longa distância por satélite de sinais de áudio, vídeo e de dados;

2) uma rede de fibra óptica, local e/ou regional;

3) uma infra-estrutura imobiliária com diferentes serviços e escritórios. Para o Autor, os teleportos decorrem de vários fatores, destacando-se a mundialização da economia, a existência de tráfego internacional de telecomunicação e a concorrência das redes internacionais e nacionais, o que se liga à desregulamentação, permitindo o acesso privado ao satélites e à comunicação a longa distância.

É bastante claro que esses imóveis inteligentes em rede propiciam à cidade uma convivência mundial. Evidencia-se que os tecnopolos e telecomunições se confundem porquanto estas lhe viabilizam as relações imprescindíveis entre os espaços de produção e de consumo, a longa distância. Ainda mais, detecta-se que "se os teleportos podem ser fato de empresas cuja atividade base é o 
encaminhamento de informação ou de empresas cujo volume de um tal investimento, hoje a maior parte dos grandes projetos no mundo prevêem de acompanhar operações de reestruturação espacial", como informa o artigo de Urbanisme $n^{0} 221$, setembro de 1987, p.53. Esse caráter de teleporto nos leva considerar a noção de descentralização/centralização de Ellul (1985), ao tratar do progresso das tecnologias doces: "se de fato essa (a descentralização) deve existir graças à difusão do computador, seria em consequência de uma decisão do poder central que sempre permaneceria senhor do modelo e dos processos de harmonização e controle, estritamente inevitáveis" (p.230).

Isto se torna mais evidente com os casos de mobilidade de empregos, viabilizada pelos meios telemáticos, exigindo dos lugares que se adaptem às novas regras de localização das atividades econômicas. Mais se viabiliza as atividades econômicas quando aos equipamentos de $\mathrm{P}$ x D e de comunicação, nos meios tecnopolitanos, se estabelece outro conjunto de elementos materiais e imateriais, (incubadoras, PMEs, cultura tecnológica etc.), que formam um ambiente inovador.

\subsection{Tecitura do ambiente inovador}

\section{a) a economia externa e as externalidades}

\section{I- Incubadora}

Nos tecnopolos tem-se materializado o apoio direto à formação e manutenção de empresas nascentes, através de uma série de benefícios, do espaço físico à orientação contábil e administrativa, o que minimiza "os elevados custos de instalação, as exigências legais e as formalidades administrativas" (Levinson e Medeiros, 1988). Na literatura mundial, esse suporte técnico-administrativo tem recebido denominações variadas: incubadora ou incubadeira, enfermeira (nurcery), pépinière d' entreprise, chocadeira (couveuse), entre outros. É um micro-ambiente pré-estabelecido, geralmente no quadro mais amplo das externalidades, na tentativa de criar um meio dinâmico para a recuperação da crise econômica e, assim, retomar o desenvolvimento local e regional. Além desses objetivos, na incubadora ocorre a metáfase (no sentido lógico do termo) entre a criação do laboratório e o sistema produtivo, que, geralmente, a induz localizar-se nas proximidades dos centros de pesquisa, para usufruir da infra-estrutura de $\mathrm{C}$ e $\mathrm{T}$ e das informações.

As referências destacam sempre o papel significativo desse mecanismo na transferência tecnológica, na criação de ambiente propício à dinâmica empresarial, à revitalização da economia, ao desenvolvimento, enfim. Certaines (1988) destaca que esses locais com serviços "à disposição dos criadores de empresas têm por fim iniciar o spin-off. Watson (1987) ressalta que em muitos países começa-se a aceitar que os centros incubadores ligados ao Campus contribuem para o desenvolvimento. Levinson e Medeiros (1988) acentuam que "essa iniciativa deve ser encarada como um veículo de descentralização e de indução ao desenvolvimento regional...". Aparecido do Santos (1987) considera-o como o "centro de efetivação do processo de transferência de tecnologia". Em decorrência desse papel disseminador de criação dos centros de pesquisas pelas pequenas empresas é que Nijkamp et alli (1987) reconhecem no "perfil de incubadora regional um conjunto multidimentsional de fatores flexíveis regionais que proporciona um sementeira potencialmente favorável de novas atividades econômicas (novas firmas ou crescentes impulsos de firmas existentes)". 
Sobre esse papel das incubadoras, Russo e Welsh (1986) chegam a considerá-las como indutoras supremas de vasta gama de benefícios, vantagens e oportunidades para o desenvolvimento econômico. Benko (1991) relaciona quatro tipos de argumentos em defesa das incubadoras:

$1^{\circ}$ ) argumentos políticos: a incubadora funciona como elemento estratégico da política de inovação;

$2^{\circ}$ ) argumentos econômicos: como nas novas tecnologias, a idéia passa à aplicação industrial, as PMEs necessitam de gestão, marketing, financiamento e adequada relação com o meio técnico-científico, o que lhes pela incubadora;

$3^{\circ}$ ) argumentos sobre a gestão: a incubadora oferece às PMEs meios para efetivar gestão e organização mais flexível às mundiais e

$\left.4^{\circ}\right)$ argumento social: na incubadora, as PMEs encontraram as condições para melhor conviver com as novas relações salariais e a qualidade de vida no trabalho requerida pelas novas tecnologias. Com algumas variantes, as incubadoras adotam algumas normas seletivas na adoção de empresas nascente. Numa pesquisa junto a 42 incubadoras norte-americanas (Watson, 1987) verificou-se que o critérios dominantes eram: exigência do espaço a ocupar, adequação com os demais locatários já presentes e concordância com os regulamentos da incubadora. O segundo critério possibilita-nos antever que tende a ser estabelecida uma maior predominância de certo setor (biotecnologia, microeletrônica etc), conforme a vocação da Universidade. O tempo máximo de permanência de uma empresa nascente numa incubadora varia de 2 a 5 anos. Com o sucesso do novo ente empresarial, ele tende a ampliar-se na proximidade do meio-ambiente em que o viu nascer.

A origem da incubadora ora provém da própria Universidade que já tem um Campus, ora de órgão governamentais, ora do setor privado. Dependendo das circunstâncias espaciotemporais (momentos de crises, organização social, força dos agentes promotores das incubadoras, rede de negócios, estrutura das organizações de ensino e pesquisa etc.) variam os tipos de promotores das incubadoras: coletividades locais, organismos patronais, agentes de setor privado, Universidade ou agências governamentais. Essas circunstâncias definem o lugar desse agente de desenvolvimento.

Como se pode notar, a incubadora reúne valores que parecem indispensáveis ao bom desempenho do tecnopolo como instrumento de desenvolvimento local e regional, dado seu caráter de disseminador de agentes da dinâmica econômica. Além disso, assume o papel de principal interface entre a pesquisa e o sistema produtivo, por agregar meios concretos capazes de aproximar a concepção à produção, territorializando "os segredos soltos no ar", no dizer de Marshall $(1917,1985)$, com a disseminação de pequenas e médias empresas.

\section{II- Pequenas e Médias Empresas (PMEs) nos Tecnopolos}

A presença destacada das PMEs nos tecnopolos se deve a múltiplos fatores. $\mathrm{Na}$ fase inicial desses parques na Califórnia, EUA-, além das facilidades para a chamada "fertilização cruzada", havia fortes incentivos dentro da própria Universidade, como estímulos do Prof. Frederick Terman, na Universidade de Stanford, o que resultaria na instalação do primeiro parque científico, em 1951 (Levy, 1986). Adicione-se mais a grande demanda por inovações provenientes dos imperativos estratégicos e militares norte-americanos (Dorfman, 1983; Saxemian, 1985), na época de guerra quentes e guerra fria (ver p.37). 
Com os grandes conglomerados, na fase áurea do fordismo, não havia muito interesse pelas inovações, porquanto elas não tinham ainda gerado consumo em massa. Desenvolvê-las significava expor o capital a sérios riscos. Às PMEs as grandes deixavam essa tarefa.

Com a crise a partir dos anos 70 (Derian, junho - 1987), as grandes indústrias deslocavam serviços para as subcontratadas; com a desintegração vertical, muitas tarefas menores passaram a ser executadas por pequenas firmas especializadas; engenheiros desempregados criaram suas pequenas indústrias em torno de um pólo de onde brotavam idéias e inovações. Isso tudo se dá sem os conglomerados perderem o controle da produção e dos lucros. A propósito dessa convivência entre grandes e pequenas firmas, quer em centros mais especializados - Califórnia, Cambridge- quer em áreas de crescimento mais recente- Escócia, sul da França - há "sofisticadas relações, como divisão de mercado, no papel das PMEs na investigação de novos produtos de valor potencial agregado para maiores firmas simples como complexos componentes, refletindo vantagens competitivas através da especialização e particular habilidade tecnológica" (Aydalot e Keeble, 1988: 14)

As Universidades forneciam o know-how para as variadas pequenas empresas firmas de consultoria (Dorfman, 1983). Nessa fase da história das empresas, pode-se repetir Schumacher (1981): "realiza-se com frequência um esforço ingente para alcançar a pequenez dentro da grandiosidade" (p.55).

Outra observação necessária se refere ao capital de risco na formação e crescimento desse tipo de empresa. Apesar das elevadas exigências se segurança para o entorno, alguns investidores têm dado credibilidade a certas inovações, por saberem da ousadia dos empreendimentos, às vezes com intermediação das incubadoras.

Derian (1987-b) destaca, no caso dos EUA- o que, por certo, serve para os demais paísesque o "perfil desses investidores de risco é, com efeito, essencial para explicar o sucesso do modelo desenvolvimento americano baseado na criação de PME de alta tecnologia, a partir do tecido universitário" (p.57). Isso tem propiciado o surgimento e melhor desempenho de muitas firmas no ambiente tecnopolitano, onde elas têm educação de custo e sua produção.

Outra alavanca, para as pequenas empresas inovadoras, encontra-se no apoio oferecido pelo Estado, tanto por suas agências de fomento, como por órgãos cuja demanda de bens e serviços não dispõem de outros fornecedores.

Além desses, outros fatores contribuíram para ser a PME o padrão de negócio mais típico dos tecnopolos:

- As PMEs constituem o melhor relais entre o sistema de pesquisa e a produção;

- Espírito empreendedor de professores, técnicos e alunos das Universidades impeliuos à formação de suas empresas, dada sua familiaridade com a transferência de tecnologias;

- os pequenos negócios desempenham por pessoas da comunidade convivem mais facilmente com a cultura local e, assim, têm maior flexibilidade para contatos informais com os laboratórios, trocas de experiências com outros pequenos empresários; ou ainda, no dizer de Schumacher (1981): "quando se trata de agir evidentemente precisamos de pequenas unidades..." (p.56); 
- é próprio dessa escala de empresa a maior probabilidade de mudança da linha de produção, como um outro tipo de flexibilidade, a técnica-produtiva (Gilly, 1987);

- do ambiente das incubadoras, já vimos, nascem pequenas empresas, muitas vezes estimuladas pelas instituições de pesquisa. É com essa dinâmica empresarial nascente que surge e, cada vez mais, se nutre todo um meio-ambiente, para onde convergem pessoal de talento profissional e mão-de-obra de baixo salário.

Nesse aspecto, é importante a observação de Scott (1988: 106) "uma divisão social de trabalho não tinha ainda começado a se formar plenamente na maior parte dos setores que compõem esses conjuntos e não tinha engendrado amplo mercado de mão-de-obra especializada local. Como resultado, esse comportamento foi, de início, relativamente independente de economias externas e forças aglomerativas. Alguns produtores, dessa forma, estabeleceram-se em locais periféricos que no início pareciam não oferecer potencialidade para a industrialização massiva. Logo, os produtores foram se afirmando nessas localidades, certamente a atividade da divisão social do trabalho e concomitante fenômeno do mercado de trabalho local começaram a induzir fortes efeitos na área local". Formada a rede diversificada de produtores, ampliam-se as economias externas, com vários níveis de serviços, fator de fertilização de mais empreendimentos.

\section{III - Os Serviços}

Os serviços participam, no âmbito dos tecnopolos, da dinâmica de toda a estrutura das instituições e dos vários patamares de todo o sistema. Eles englobam não somente empresas, mas também os meios de comunicação, as múltiplas atividades dos institutos de pesquisa e de formação que se justapõem aos demais órgãos públicos e privados envolvidos.

Para Gadrey (1989), as necessidades de serviço têm crescido em face de, pelo menos, meia dúzia de fatores:

1) complexidade e crescimento dos inputs informacionais;

2) economia de tempo para muitas atividades;

3) redução de riscos às empresas, às pessoas ou aos bens;

4) integração da produção e da utilização, dada a proximidade temporal-espacial entre produtores e consumidores, e 5) integração da produção e do consumo.

Todos os fatores, relacionados por esse economista da Universidade de Lille, dizem respeito à vida tecnopolitana.

Diz-se do tecnopolo ser o melhor "lugar para trabalhar e viver", enquanto Fourastié (1989) defende que os serviços ajudam a "melhor fazer e a melhor viver", porquanto ele observa que os valores terciários invadem a vida econômica, com o progresso técnico. Com o progresso técnico uma maior divisão social do trabalho se estabelece, exigindo a ampliação das funções intermediárias (comércio, transporte e serviços ampliados) para haver sistematização e racionalização, com o fim de assegurar a produção e a venda (Mandel, 1985).

Para Jalabert (1990), “os serviços são, em grande parte, serviços para as indústrias, com a divisão do trabalho e externalização de algumas funções, a emanação mesma do sistema produtivo em recomposição". 
No âmbito dos tecnopolos, há uma forte gama de atividade classificada como serviços, às vezes ultrapassando as indústrias. Em um de seus estudos, Scott (1988) chama a atenção que entre a produção artesanal e a indústria de alta tecnologia, "os serviços também fazem parte (e até em grau sempre crescente) de um conjunto de setores de produção flexível altamente sintomático" (p. 105). É o que alguns costumam denominar de "bens imateriais": design, software, consultoria, telecomunicações, informações etc. Há mesmo o tecnopolo FUTUROSCOPE (Poitiers, França), totalmente dedicado à economia terciária (Bruhat, 1990, p. 159 e ss.).

\section{IV - Ambiente Cultural dos Tecnopolos}

O ambiente cultural nos tecnopolos é moldado pelas grandes universidades, pelos inúmeros institutos de pesquisa públicos e privados, tipos variados de faculdades e escolas técnicas. À medida em que se envolvem as empresas (ou o espírito empresarial) e a ação do governo, numa mescla de atores com objetivos de desenvolvimento, é estabelecida a "fertilização cruzada", geratriz de nova organização da produção. Nos centros mais dinâmicos, não se restringe apenas a unidades tecnológicas das universidades, visto que o ambiente cultural de um tecnopolo se processa, também, com a universidade das formações humanísticas. Ao conjunto das matemáticas e das engenharias, ultimamente têm-se associado o ético e o estético.

Contudo, a cultura dominante nas sociedades tecnopolitana é a edificada pelas ciências e técnicas e pelos negócios. Na atmosfera desse ambiente respira-se a discussão do invento, da transferência tecnológica, a busca de outros bens para manter aceso o mercado.

Voltando-se aos albores do Vale do Silício, seminal dos tecnopolos no mundo, vamos encontrar na Universidade de Stanford o cerne da cultura técnica potencializado pelos laboratórios privados da AT \& T. A organização do parque empresarial em torno dessa Universidade, conduziria à formação de um modelo que se ampliaria pelo país e pelo mundo hodierno. O vetor cultural voltava-se para as inovações. Saxenian (1985) dá-nos a conhecer o que noticiara o Wall Street Journal (14/02/83): em 1983, cerca de 33 Estados americanos gastaram US\$ 250 milhões em P x D para acelerar esse tipo de indústria (HT), enquanto centenas de governos locais ofereciam incentivos às indústrias inovadoras. Ainda, nos anos 90, é o Vale do Silício, com seus centros avançados de pesquisa, que mantém os EUA na competitividade mundial da indústria eletrônica, segundo o geógrafo A. Scott, da UCLA.

Na borda atlântica, o mesmo ocorre: é com o Massachusetts Institute of Technology - MIT - e com a Universidade de Haward que tem início o grande esforço para o domínio das altas tecnologias (HT). O boom de HT do Nordeste dos EUA iniciou-se nos anos 70, com a grande contribuição de seus centros de formação de mão-de-obra altamente especializada. Dorfman (1983) testemunha que, no final da década de 70, essa mão-de-obra ganha menos em Boston, mas a economia local ajuda os já empregados a se manterem em Massachusetts, fortemente ajudados pelo ambiente cultural.

Embora sem o destaque de Stanford ou do MIT, a Universidade do Estado do Arizona criou um parque industrial nos arredores de Phoenix com 60 companhias de pesquisa voltadas para aviação e biotecnologia. Anteriormente, a Faculdade de Ciências Aplicadas e o Centro de Engenharia de Alto Nível desenvolveram várias linhas privilegiadas, como o estado sólido, a informática, recursos energéticos, transportes, etc., o que contribuiu para a formação de um bom clima para os negócios (Manzagol, 1990).

Nos demais países, não difere muito do que houve nos EUA. Os tecnopolos mais dinâmicos exprimem o caráter da universidade que lhes forja. 
O Japão, à parte a cidade científica de Tsukuba, optou por seu plano estatal de desenvolvimento regional pela formação de tecnopolos médios, em muitas cidades. Concordando com o Plano, o governo local tem o aval do MITI para realizar desde o planejamento até financiamentos. Para isso, exige-se a existência de universidades no local e sua colaboração com a indústria, através de assistência técnica e de pessoal, acesso a laboratórios etc. Várias dessas cidades já têm especialidades com destaque mundial: Nagaoka e Kurome-Tosu (projeto e moda), Hamamatsu (ind. musical), Mishiharima e Goboh (saúde e lazer), além da mecatrônica em outras cidades, como Oita, Kokubu e Sasebo.

Quando se faz necessário formar ou manter o ambiente cultural típico da vida tecnopolitana, quebram-se as tradições, desmonta-se a cultura e em seu lugar afeiçoam-se novos modos de ver, de sentir, de valorizar o que se afirma com os interesses do que se tem como novo, como moderno. No Japão, o plano tecnopolitano de Toyama testemunha esse cenário de rupturas.

No que se refere à Tsukuba, temos uma cidade criada ex-nihilo, com verbas públicas, onde se estabeleceram escolas médias e superiores e vários institutos de pesquisa, operacionalizados por técnicos, professores e cientistas de Tóquio e de outras regiões e países, no intuito de descentralizar as atividades de P x D da capital. Essa cidade tem pouco mais de duas décadas de existência. Estudo crítico de Glasmeier (1988) mostra que "focus" de P x D não levou à propulsão do crescimento econômico, baseado na indústria, e poucos empregos foram criados. Publicações da HUDC (Corporação de Desenvolvimento Urbano de Habitação) de março de 1989, divulga dados com uma população de 160.000 habitantes, para uma projetada de 220.000 habitantes, vivendo com as melhores condições de infra-estrutura urbana.

$\mathrm{Na}$ Europa, o ambiente cultural desempenhado pelas universidades e demais escolas para verificar os pólos industriais em crise, nos anos 70, tem suas especificações. Primeiro, a descoberta dos tecnopolos não se fez puramente por motivos bélicos, como nos EUA; segundo, a vida acadêmica europeia estava mais amadurecida, o que lhe daria uma visão crítica e ética sobre o desenvolvimento científico e o bem-estar das populações; terceiro, os atores dos tecnopolos não eram apenas o governo, as empresas e as universidades, mas também as coletividades, sindicatos etc.; quarto, os tecnopolos ressurgiam como tentativa de retomada do crescimento, da saída da crise a atingir nova fase de desenvolvimento baseada no novo paradigma técnico-industrial. Com esse novo cenário forma-se o que Aydalot (1988) denomina de "ambiente inovador".

$\mathrm{Na}$ dianteira dessa decisão ficou a França, mobilizando seu potencial científico e o espírito empresarial, desencadeando processo de "febre tecnopolitana" (Certaines, 1988), apoiado pelos vários níveis de governo. Conforme a capacitação técnico-científica de cada universidade, irradiava-se um parque industrial de HT em seu campus ou em suas proximidades: Montpellier, com cinco parques especializados (comunicações, biotecnologia, médico, telecomunicações e o de lazer); Grenoble ou 'Zone pour I'Innovation et les Réalisation Scientifiques et Techniques (ZIRST) em Meylan, cujas forças locacionais são fortemente dominadas pelo ambiente cultural (imagem de inovação, meio científico); Toulouse, tem sua proto-indústria de HT iniciada com a indústria aeronáutica decorrente da Escola Nacional de Aviação Civil e do Centro Nacional de Estudos Espaciais e, a partir dos anos 70 com, algumas fortes multinacionais, como a Motorola, o que fez as lideranças locais se afeiçoarem mais à "matéria cinzenta"; Lyon, destacando-se por seus 20.000 pesquisadores em 450 laboratórios públicos, 21 escolas de engenharia, 4 universidades com 70.000 alunos, dando-lhes condições para implantar três tecnopolos: La Doua, Gerland e Ecully. A decisão pioneira da França já lhe favoreceu a elaboração de 
um primeiro relatório sobre seus 20 anos de tecnopolos (Bruhat 1990).

Esse comportamento irradiou-se por muitos outros países do Continente, onde já havia os ingredientes tecnológicos e culturais propícios a auxiliar as iniciativas empresariais locais. É o caso da Bélgica (Louvain - la- Neuve), da Holanda (Universidade Tecnológica de Delft), da Grã-Bretanha (Cambridge, Heriot - Watt), da Alemanha (Heidelberg, Hamburg, Berlin, München), da Espanha (Madri, Catalunha, Valência, Basco).

A escolha, pelos empreendedores, de ambiente favorável ao bem-estar para localizar os parques científicos têm sido fortalecido tanto pela animação da vida acadêmica, como pela condição de afastar-se das externalidades negativas, sociais e ambientais.

Este fato constrói outro aspecto da vida cultural dos tecnopolos.

\section{b) O Capital Humano}

\section{I - Caráter da Cultura Tecnológica}

Ao abordarmos a economia externa e as externalidades dos tecnopolos, foram tratados alguns aspectos do ambiente cultural, na posição de componentes acionadores do processo econômico da realidade tecnopolitana, tanto no que se refere aos seus instrumentos materiais e concretos, como no estabelecimento de novas atitudes normativas que ajudam a impor um comportamento planejado e técnico.

O que se deseja tratar agora é a formação de um novo ente social, imprescindível na contextura tecnopolitana: o profissional técnico em suas várias dimensões, quer engenheiro, quer administrador, quer pesquisador. O comportamento do lugar ou da região na elaboração de seus quadros; a origem e o processo de absorção da camada de técnicos que comandam a vida tecnopolitana. São essas algumas de nossas preocupações para esboçarmos um breve panorama do capital humano que compõe esse novo tipo de espaço de nosso estudo.

Entre outros aspectos da formação dos pólos técnico-científicos, destaca-se a cultura tecnológica, plasmada ora na sua proto-história, ora a partir de decisões recentes do lugar ou da região. Naquele que se edificaram na evolução do processo produtivo, parte significativa dos profissionais técnicos se adestraram nas próprias empresas, enquanto nas sociedades tecnopolitanas cuja criação foi induzida recentemente, esses quadros foram recrutados de outras paragens do País ou do exterior. Tanto num como no outro caso, tem sido imprescindível o papel da educação e da imigração de força-de-trabalho altamente qualificada. Nos pequenos centros a ação imigratória também é verdade para a mão-de-obra desqualificada (Scott, 1983, p. 38).

A história da indústria do Nordeste dos EUA bem explica a potencialidade encontrada pela nova onda geradora do boom da HT de Massachusetts, onde fica a famosa Rodovia 128, a partir dos anos 70. É reconhecível, também, que suas escolas de alto nível e seu ambiente cultural não só mantiveram o atrativo da região como foram responsáveis pelo atendimento à demanda de talentos profissionais (Dorfman, 1983): nos dois últimos anos da década passada, $80 \%$ da mãode-obra com curso superior das firmas formaram-se em Massachusetts.

Nos tecnopolos situados em pequenos lugares, onde não havia tradição industrial nem grandes escolas tecnológicas, houve a intermediação de centros mais portentosos, com a transferência de quadros 
e no aporte de estabelecimentos de ensino e pesquisa. Os mais típicos exemplos desse caso são Tsukuba (Japão) e Sophia-Antipolis (França). O primeiro recebera pessoal altamente qualificado de Tóquio, embora hoje já contribua com especialistas em opto-eletrônica e eletrônica para o tecnopolo de Utsonomiya - Tochigi. (Couvidat e Giusti, 1991). O primogênito dos tecnopolos franceses foi produzido pelos engenheiros e pesquisadores que desceram das grandes escolas da região da Île-de-France. É a busca e a montagem do lugar agradável para trabalhar e viver.

Além de lufar para trabalhar e viver, os tecnopolos de enquadram no cenário traçado por Ellul (1954, 1968: 349 e ss), em que a realidade da aplicação prática e eficaz, portanto técnica, se desenha na sequência dos seguintes passos:

a) escolhe-se, nos dados científicos, o que parece utilizável;

b) procede-se à simplificação indispensável à aplicação;

c) intervenção das matemáticas para chegar à aplicação das técnicas;

d) espírito de experimentação técnica.

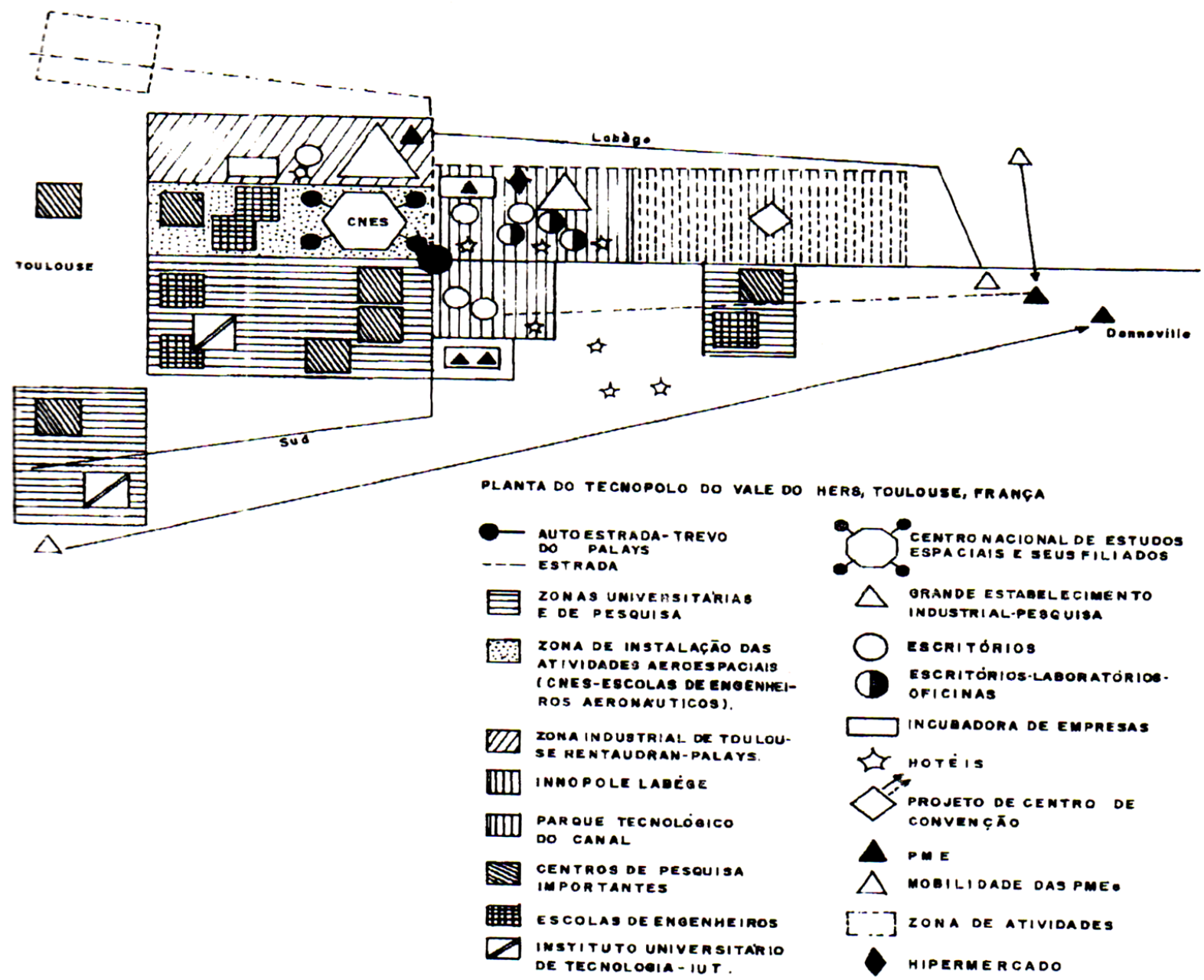


Assim se atingiria um suporte cultural possível de manter hábitos e impor competência. Para isso, mecanismos de ação concreta se efetivam entre as instituições.

No ambiente tecnopolitano há uma grande fricção entre os estabelecimentos de ensino e pesquisa e as empresas, através de relações variadas de contratos de pesquisa, bolsas tecnológicas, estágios e teses de estudantes (Jalabert, 1990). Forma-se, assim, local e regionalmente, uma típica cultura tecnológica.

Essa cultura não se restringe ao circuito das relações escola-empresa, porquanto se irradia nas diferentes instâncias da sociedade, através de uma série de intermediações, como as redes de informações e de comunicação, o que resulta na divisão de hábitos e demanda de competência.

Como é cada vez mais corriqueira essa manifestação de contatos entre as elites tecnopolitanas - engenheiros, administradores, empresários, pesquisadores etc. -, na estruturação desses lugares se instalam centros de animação e de encontros, indutores desses fluxos, como se pode ver (no mapa 01) planta do tecnopolo do Vale de Hers, em Toulouse (Dreulle e Jalabert, 1987). Esses fluxos se dão por contingências próprias da interdependência dos diversos atores que comandam a vida tecnopolitana.

É provável que a firmação da cultura tecnológica favoreça a capacidade de reprodução do tecnopolo, porquanto esta é, conforme Gilly (1990: 107), "relativamente endógena, caracterizada pela densidade e intensidade particularmente forte das relações múltiplas (formais/informais, materiais/imateriais, mercantis/não mercantis) ". Esse conjunto de articulações, para Gilly, produz a espacialidade do tecnopolo como sistema produtivo local. Nesse mesmo sentido, Scott (1988) lembra que "as localidades industriais são muito mais do que simples locais da produção industrial. Eles também representam comunidades humanas duráveis nas quais, com o passar do tempo, acumulam tradições e formas de cultura particular" (p. 38). Nessa cultura particular se insere também o caráter tecnológico, com a formação e o crescimento da variedade de trabalhadores.

\section{II - O Mercado de Trabalho}

O mercado de trabalho nos tecnopolos é marcado por dois aspectos destacados: 1) uma expressiva dualidade social e 2) relações de trabalho definidas pela flexibilidade ou quebra da regulação fordista.

Com relação à dualidade social, destaca-se a presença de uma força-de-trabalho voltada aos níveis de gestão e de pesquisa e engenharia, cuja participação relativa, no conjunto dos trabalhadores, é superior a que ocorre nas indústrias tradicionais.

Como é corriqueiro nos centros de inovação, o tecnopolo deve dispor de boas unidades de formação de pessoal altamente competente, orientadas às linhas de especialização de sua vocação: biotecnologia, eletrônica, novos materiais etc. São cientistas, pesquisadores, engenheiros e pessoal de gestão que têm sua vida dedicada ao intenso trabalho de criar e/ou absorver inovação frente a concorrentes do mundo inteiro.

Para atrair e manter esse pessoal de alto nível, o tecnopolo localiza-se num meio-ambiente saudável, com ótimas condições de moradia, transporte, lazer e de trabalho. Daí porque a localização dos tecnopolos é isenta das externalidades negativas, típicas das grandes aglomerações.

Para as tarefas de menor exigência técnico-científica - serviços corriqueiros, produção e montagem etc. - utiliza-se uma mão-de-obra desqualificada, em alguns países compostos de imigrantes ilegais, mulheres 
e crianças. Em meado da década passada, Castells (1985) dizia em Viena que "a estrutura ocupacional da indústria de alta tecnologia é caracterizada por uma distribuição bipolar de capacidades, hierarquia e rendimentos. Esta estrutura ocupacional é ampliada pelas características sociais do mercado de trabalho, homens brancos no topo e mulheres e minorias no nível inferior da pirâmide" (p. 9).

Em casos em que ao tecnopolo é reservada uma diminuta área, para os contingentes de trabalhadores não qualificados, conhecidos como "colarinhos azuis", não se dispõe de habitação, mantendo-se uma migração pendular com as cidades ou bairros dormitórios na circunvizinhança, fato bem destacado na região do Vale do Silício, marca realçante da segregação social.

No que se refere às relações de trabalho, praticamente as duas grandes categorias de mãode-obra são submetidas a novos ditames, enfeixados no que se conhece como flexibilidade.

Nos centros industriais de alta tecnologia prevalece a flexibilidade nas relações de trabalho, decorrente da instabilidade do emprego e da ausência da sindicalização, o que tem conduzido os trabalhadores a aceitarem contratos de trabalho fora das regras comumente vigentes na fase do regime de acumulação fordista. Essa ausência de sindicatos é uma tônica nesses centros de indústrias avançadas onde há "um bom clima" de negócios e inclinações políticas conservadoras (Scott e Storper, 1988).

Por sua vez as empresas dão preferência aos trabalhadores marginais (imigrantes ilegais e mulheres), o que favorece a essas firmas barganharem menor custo nas tarefas de rotinização (Scott, 1988), visto que "a mudança tecnológica subjuga o trabalho e torna-o menos resistente às estratégias do capital” (Castells, 1985).

A alta rotatividade de mão-de-obra, nesses centros, possibilita, ainda, a seleção dos mais aptos, dada à elevada demanda por trabalho.

$\mathrm{Na}$ abordagem sobre o processo de trabalho e flexibilidade da relação salarial, Lipietz e Leborgne (1988) situam o engajamento individual como do tipo "californiano", por ser expresso no Vale do Silício, onde domina a "cultura empresarial com cimento ideológico" dos principais liberais. Esses Autores, entretanto, reconhecem que não há uma hegemonia de um tipo de relações de trabalho, porquanto os centros de alta tecnologia agregam variadas formas de organização da produção.

\section{III - Sociedade Dual}

Vimos que o mercado de trabalho nos tecnopolos conduz a uma sociedade dual. Pretendemos aprofundar este conceito e examinar um pouco dessa realidade no contexto de nosso objeto de estudo.

Um caráter de sociedade dual, no âmbito do Estado de Bem-Estar, foi evidenciado por Mandel (1988) em relação a dois setores da classe operária nas cidades internacionais de Nova Iorque, Chicago e Los Angeles: um setor ainda protegido pela Previdência Social e um outro de 10 a $15 \%$ da população dos países ricos ou 25 e $30 \%$ da classe operária - que vive em bairros sem serviços públicos, cujas condições de vida estão mais próximas às do Terceiro Mundo.

Não é desse tipo de polarização que tratamos.

Outra abordagem é apresentada por Gorz, em Adeus ao Proletariado (1982), ensaio sobre o imperativo técnico e a exigência moral. Nesta obra, o conceito de sociedade dual refere-se às duas esferas da produção social: a heteronomia (produção programada para o funcionamento da sociedade) e a autonomia ("os indivíduos produzem de forma autônoma, fora do mercado, com os desejos, os gostos e a fantasia de cada um"). 
Não se trata também de comentar as diferenças salariais dos trabalhadores, especialmente nos EUA, a nível de competência mundial (Mandel, 1971). Sabe-se que este fenômeno levou a uma série de mudanças locacionais, especialmente das indústrias automobilísticas nos anos 50/60, bem como ao fluxo de mão-de-obra mais barata (negros, imigrantes latinos e asiáticos), quando a indústria siderúrgica americana chegou a ocupar $50 \%$ de sua força-de-trabalho de negros.

Fora, ainda, da dimensão de que tratamos em relação à sociedade tecnopolitana, deseja-se rotular de dual (P. Labarde no Le Monde de maio/81, citado por Ellul, 1985) uma sociedade, como o Japão, que dispõe de um "conjunto tradicional encarnando a herança das tradições culturais".

No âmbito do novo espaço aqui estudado, que se forma com as novas tecnologias, a literatura especializada tem se referido à grande massa de excluídos da ciência e do progresso, os burn out ou grillés, em grande parte formados por imigrantes ilegais e mulheres. Por outro lado, no mesmo cenário convivem cientistas, engenheiros, técnicos com elevada capacitação técnico-profissional usufruindo das "benesses" do novo.

No cap. 9 de La Fièvre des Technopoles (Certaines, 1988) dá-se como causas do agravamento do dualismo social a redução da oferta e a exigência da qualificação, daí decorrendo os excluídos do trabalho, os excluídos do conhecimento (das inovações tecnológicas) e os excluídos do sistema de proteção social. Nos tecnopolos, esses excluídos são utilizados nas tarefas desqualificadas.

Segundo Scott (1988), a divisão técnica do trabalho extrapola-se para a divisão social do trabalho, o que leva a uma dicotomia, própria da sociedade tecnopolitana. Isso fica bem claro quando o Autor revela a segregação social e espacial no sunbelt.

"Nos modernos centros de crescimento industrial de HT do "sunbelt", os mercados de trabalho locais, repentinamente segmentado, tendem a incluir quadros altamente qualificados de administradores e de técnicos, de um lado; e pelo outro lado, trabalhadores desqualificados, frequentemente imigrantes. Esses dois grupos misturam-se estreitamente nos lugares de trabalho, mas são inclinados a se evitar, escrupulosamente, na ampla esfera da vida social. Uma das maneiras de expressão dessa fuga está nas formas de comportamento residencial que, ativamente, produz, em essência, bairros segregados. Padrões de segregação social e espacial são, então, promovidos a nível de resolução mais elevado, através dos controles de uso da terra, regulamentos de edificações e legislação de planejamento que procura proteger bairros de mais alto "status" da invasão de famílias de baixo "status" (p. 39).

Apesar desta distorção social, a divisão do espaço comunitário, conforme Scott, "ajuda a obter reprodução regular de categorias ocupacionais e sócio-econômicas relevantes pela promoção cultural homogênea do domínio primário em que a vida familiar, troca interpessoal e atividades de lazer são situados".

Antes de Scott, Saxenian (1985), estudou o arcabouço sócio-espacial do Vale do Silício: "os profissionais qualificados (engenheiros e cientistas) e os trabalhadores desqualificados de ex-agricultores da Califórnia, latinos, filipinos e mexicanos, cujas residências se esparramavam pelos subúrbios de San José, enquanto os trabalhadores altamente qualificados moravam no péda-montanha, em Palo Alto. Essa segregação habitacional e econômica se expandiu de tal modo que há, hoje, uma regionalização da divisão espacial do mercado de trabalho: para o norte, a mão-de-obra é altamente qualificada e 
à medida em que nos dirigimos para o sul, baixa o padrão de vida nas cidades dormitórios mal arrumadas dos trabalhadores desquloficados".

O mesmo tipo de discriminação e segregação espacial também é nítido no Japão: no tecnopolo de Kagoshima, o governo local construiu uma cidade nova para ser usada como área de moradia dos cientistas e engenheiro, enquanto um programa de treinamento para mulheres trabalhadoras no setor de produção está indicado no famoso Plano de Tecnopolos do País (Fujita, 1988).

A segregação no regime flexível difere do que ocorrera nas fases anteriores do capitalismo. Denota-se uma polaridade que não se revela no âmago das classes sociais, como ocorria anteriormente. Isto foi muito bem explicado por Castells (1985) num Simpósio da ONU, em Viena: "A produtividade gerada pela alta tecnologia e o rendimento que induz nos setores profissionais mais bem remunerados cria as bases (quer em termos de investimento, quer em termos de procura) para uma ampla série de atividades de consumo e de serviços de tecnologia mais convencional, alimentada pelo trabalho deslocado de outros setores ou países. Os dois processos reforçam-se e um não pode existir sem o outro. Assim, a polarização da força de trabalho é um processo necessário que e fundamental para o modo de desenvolvimento baseado na informação. Contudo, esta polarização não origina um novo processo de formação de classes, porque os dois pólos não estão numa relação direta com a produção. Ambos são elementos do mesmo sistema de crescimento polarizado e de reajustamento das técnicas de trabalho" (p. 8).

Pela clareza e abrangência das palavras do iminente professor de Berkeley, não cabe uma exegese. O que se pode dizer repetir as palavras do filósofo: "os efeitos da ciência não são simples, nem para melhor, nem para pior. Eles são profundamente ambivalentes" (Morin, 1990).

\section{IV - Complexidade Mundial à Multiplicidade Local}

$\mathrm{Na}$ abertura desta década, a mídia nos grandes centros do mundo tem acordado para o que se convencionou chamar de "nova (des)ordem mundial (CadernosWorld Media - Folha de SP, 19 a 21/12/90), enquanto o meio acadêmico se tratava o mundo como "um caos que se edifica" (Dollfus, O. citado em Durand, Levy e Retaillé, 1992:79).

Esse caos ou essa (des)ordem marca, no entanto, um momento adequado para perspectivas realçantes e tendentes a revelar algumas perspectivas.

Ao se indagar sobre o fim da Geografia, Richard O'Brien (in Durand et alli, 1992) relaciona as complicações por que tem caminhado o mundo que vivenciamos; exploração das técnicas; aproximação dos lugares, com a rapidez das comunicações e das informações; a quebra das fronteiras nacionais são algumas entre tantas. Com as grandes mudanças nas duas últimas décadas, inicia-se a reestruturação econômica do capitalismo mundial, acompanhando-se de rápida desmontagem de todo o sistema que se consolidara no primeiro quartel do $2^{\circ}$ pós-guerra. Como nos diz Levy, "a economia-mundo desestabiliza a geopolítica", dentro do que ele batiza de Fim de uma Era (Durand et alli, 1992). Assim, tudo passou a ser imprescindível, como conta o poeta:

Baile sob o mistério neste mundo que queima rápido o que ontem era verdadeiro não será verdade amanhã (Lúcio Dalla, em Baila, Baila, Bailarino). 
Mesmo ante essa competividade, Dollfus (1990) esboça, no campo da Geografia, sua teoria de Sistema-mundo, em que dois campos são distinguidos: o internacional, de base territorial, codificável e mensurável; e o transnacional, a-territorial, formado pelos fluxos que desprezam fronteiras e pelos espaços das firmas, dos grandes grupos industriais e das finanças com suas trocas internas de informações. As interações desses dois campos formam o espaço mundial. Uma grande firma, exemplifica esse Autor, é internacional por sua localização em diferentes países, mas também transnacional por seu sistema de informação, seus jogos financeiros, sua cultura. O tecnopolo se conjuga nas interações desses dois campos porquanto aos interesses oligopólicos que, no fundo, "determinam suas estratégias em função das de seus adversáriosparceiros, dirigidas permanentemente à concorrência, à competição e aos conflitos". Para isso, cada tecnopolo cria sua especificidade, sem perder a construção de lugar-mundo que deve manter. Esse caráter (de lugar-mundo) lhe é assegurado por relações as mais variadas a nível local, regional, nacional e internacional, mediante a multiplicidade de atores neles presentes com variados interesses, o que é inerente à dinâmica que lhe estabelece o perfil de excelência (Chanaron et alli, 1990).

\section{c) Interface Empresa -Governo - Universidade}

Nosso interesse com esse tema se volta a explicitar o papel de mais um instrumento dirigido à vitalidade dos tecnopolos. Por assumir algumas funções organizativas, a instituição (quer de caráter privado, misto ou público) que agrega os objetivos de interface entre universidade, governo e empresa, tende a desencadear ações relativas ao espaço geográfico. É esse particular que nos interessa tratar nesse tópico do trabalho.

Comumente, o que chamamos de interface dos órgãos inerentes aos tecnopolos é uma instituição criada no processo histórico de formação de pólo que serve de agente de aproximação doa atores mais dinâmicos (empresa, governo e universidade) em seus diversos campos de atuação. Destacamos que pode ocorrer multiplicidade desses agentes, conforme interesses específicos de alguns setores, mesmo no caso das engenharias. Mas é comum o tecnopolo possuir um órgão de interface de nível mais abrangente. Neste sentido, Certaines (1988) não fala de interface no capítulo 6, mas de péppinière d'entreprise, des amenageurs locaux, no caso francês, quando trata de algumas funções típicas do que chamamos de interface. Em recentes publicações que relacionam dados sumários sobre os pólos tecnológicos no Brasil (Medeiros et alli, 1992) e sobre os science parks do mundo (Couvidat e Giusti, 1991), encontramos sempre informações sobre o organismo de interface existente em cada um deles.

São variadas suas funções e objetivos, conforme o país, a realidade local e o processo de formação do pólo ou parque.

O que se apresenta como linha básica de suas ações, inicialmente, é de administradora do parque, o que levaria a expandir suas funções, a medida que se tornam mais complexas as instalações empresariais, as interações pesquisa-produção, as relações governo-empresas, as múltiplas linhas de intercâmbio necessárias à dinâmica das empresas inovadoras à expansão de seu raio de abrangência. O Instituto Mediterrâneo de Tecnologia, no tecnopolo de ChâteauGambert, em Marselha, apresenta-se como interface, desde 1987, com uma ação de aproximar indústrias e instituições científicas à escala nacional e internacional (Bruhat, 1990: 119-120).

A estrutura de interface Associação SUN do tecnopolo de Lund, sul da Suécia (Parque de Pesquisa IDEON) foi modelo para o Projeto da Associação UNITECN do tecnopolo de Talense - Pessac - 
Grandignan, vizinho a Bordeaux, (Bruhat, 1990) por sua capacidade de "estimular as inovações pelos estreitos contatos e das fertilizações cruzadas entre invenção e a comercialização de um novo produto ou processo de fabricação" (Faramond, G.-in Autrement nº 74, p. 126).

Ainda em França, onde tem sido difícil de se implantar o sistema de interface, no tecnopolo de Bordeaux funciona uma exemplar estrutura com o escritório de valorização industrial que tem assegurado transferência de tecnologias nos vários pólos da aglomeração de Bordeaux. A Universidade Tecnológica de Compiègne - UTC - também dispõe da Associação GRADIENT que "centraliza e gera as relações contratuais da UTC com a indústria (Bruhat, 1990). Como na UTC, há, na Universidade Tecnológica de Berlim (UTB), o Centro de Transferência Tecnológica "diretamente responsável pela promoção e cooperação entre os Institutos e as PMEs, mantendo contratos com essas companhias". (Berlin Centres for Innovation and New Enterprises Technology and Innovation Park Berlin, 1985: 45).

Tem-se relacionado uma série de outras funções desse tipo de agente intermediador, destacando-se:

- negociar com agências públicas recursos para a implantação de benefícios de infraestrutura para o pólo que se instala;

- intermediar interesses das empresas junto à Universidade, no sentido de transferência de tecnologia, assessoria, prestação de serviços etc.;

- centralizar informações - banco de dados - sobre a capacitação empresarial e potencial da Universidade e realizar sua divulgação;

- promover eventos (congressos, conferências, cursos etc.);

- fomentar e apoiar a criação de novas empresas de base tecnológica;

- gerenciar pesquisas e projetos etc.

Um papel destacado refere-se à animação do pólo, nas diversas etapas de organização: congregar os agentes financeiros, atrair empresas externas, captar apoio governamental para a organização do espaço e funcionamento da estrutura de apoio às empresas nascentes (incubadora), bem como a montagem de outras instituições e equipamentos necessários à vida sócio-econômica que se delineia.

Para o funcionamento adequado e mais eficaz, as experiências têm mostrado que se torna imprescindível a participação em sua diretoria executiva de representantes das várias instituições envolvidas. A congregação dos diversos atores envolvidos tem oferecido resultados positivos e acima do somatório das ações que cada um teria isoladamente. Este fato contribuiu para adicionar termos como sinergia, simbiose, fertilização cruzada, triângulo de ouro ao vocabulário tecnopolitano.

No local ou região onde o tecnopolo é resultante de projeto governamental, o envolvimento de representantes da comunidade (líderes, políticos locais) e dos trabalhadores, apresenta-se como uma iniciativa propulsora de sucesso do tecnopolo.

Das articulações técnicas, políticas e organizacionais da instituição gerenciadora do tecnopolo - instituto, agência, associação ou centro - se produz a 'fertilização cruzada' entre Universidade, empresa e governo. A eficiência e a continuidade das interligações retroalimentam o desempenho dos agentes que tendem a edificar o micro-sistema desse tipo da produção moderna.

Esses micro-sistemas se organizam em determinadas fases da história, com o fim de atender a demandas por inovações, como veremos a seguir. 


\subsection{Grandes demandas por inovações tecnológicas: fases}

Entendemos, como Benko (1991), serem "as inovações ou novas tecnologias a sistematização dos conhecimentos e das técnicas que permitam à indústria realizar concretamente uma produção". Comumente essas criações se derivam das pesquisas quase sempre realizadas em lugares de economia de aglomeração e mão-de-obra altamente qualificadas, onde há elevados fluxos de informação, forte relacionamento de Universidade e Institutos de pesquisa com as empresas.

Essas condições não ocorrem em qualquer lugar. Esses lugares potenciais nem sempre são utilizados de modo contínuo, estabelecendo-se reservas, reservas que serão utilizadas em momentos históricos adequados, refletindo-se no caráter social e geográfico do próprio lugar.

A propulsão de novas tecnologias e, em consequência, o enquadramento desses loci inteligentes no processo de desenvolvimento decorrem de fortes demandas desde a $2^{\mathrm{a}}$ Guerra Mundial, intensificadas com a guerra fria e com a acentuada crise do fordismo.

a) Fase dos conflitos mundial e regional. - O momento das guerras globais ou regionais tem se revelado como exigência de meios técnicos para responder a questões e impasses emergenciais. Ora é o enfrentamento às situações ambientais inóspitas (em desertos, em densas florestas pluviais etc.), ora é a ampliação das forças inimigas não contidas pelas armas e estratégias tradicionais, muitas vezes a própria fadiga das tropas ou o cansaço da opinião pública ante ao extermínio permanente, exigindo a utilização de novos meios, e técnicas mais eficazes. Para atender a essa demanda de inovações, sempre entrou o batalhão de pesquisadores de cientistas e de engenheiros que projetam novos bens e processos revolucionários, posteriormente repassados ao sistema de produção em massa.

Tendo como principal timoneiro os EUA, na década de 1940 situa-se o primeiro momento de criação das inovações tecnológicas que norteiam nosso mundo. Embora perverso, este é um rico e fértil percurso de descobertas e invenções.

Dentre tantos outros, dois eventos técnico-científicos, nesta década, marcam o destino da humanidade:

1) progresso da fissão nuclear que levou à descoberta do plutônio (1945) e

2) a invenção do transistor (1948) que contribuíra para o enorme desenvolvimento da informática.

Não devemos olvidar que nessa fase da história, as inovações respondiam exigências bélicas ou nasciam das preocupações dos militares. Embora não fossem resultantes de políticas de $\mathrm{C}$ e $\mathrm{T}$, as pesquisas se realizavam no conteúdo dos orçamentos estatais ou, mais particularmente, do Departamento de Defesa.

Examinando a historiografia da $2^{\text {a }}$ Guerra Mundial encontramos em Innis (1949: 241), em referência à ação da pesquisa:

"Nesta guerra, muito mais do que em qualquer outro conflito anterior, o resultado dependia muito mais do cientista do que do soldado Durante toda a luta, os laboratórios foram teatro de intensivos esforços no sentido de produzir novas armas que dessem vantagem para um dos lados, ou aperfeiçoar invenções que contrabalançassem as armas inimigas.

A evolução e a aplicação cada vez mais vasta do radar, a luta para melhorar ou neutralizar as armas da guerra submarina, a corrida para o desenvolvimento dos projéteis- 
foguetes e dos aviões de propulsão a jato que foram apenas alguns exemplos de trabalhos em que êxito ou o fracasso dos cientistas podiam mudar o curso da história”.

Correlacionadas com esses fatos, as informações de Michel Borrus (Darrigol, 1985), nos levam à gênese dos tecnopolos desta época. Segundo Borrus, o chairman do Departamento de Engenharia Elétrica da Universidade de Stanford, Prof. Frederick Terman, armazenara experiências de guerra: "no exército, capitais militares eram utilizados para pesquisas, notadamente em matéria de radar, equipamentos elétricos" (p. 37). Na década de 1950, recursos federais ( 1 a 5 milhões de dólares/ano do Departamento de Defesa) possibilitaram ao Prof. Terman estabelecer a sinergia entre Universidade e indústria, utilizando-se de alunos de Estados Sólidos Eletrônicos, chegando em 1961 com a melhor equipe do País nessa área do conhecimento técnico. Alguns dados nos aclaram do forte vínculo estabelecido entre a Universidade de Stanford e as indústrias, sob a liderança do referido professor: engajamento no programa de Estados Sólidos Eletrônicos de 17 fortes empresas, entre as quais IBM, HewlettParkward (de dois de seus ex-alunos), Texas Instrument, contando com 30 professores, 30 pesquisadores, 400 estudantes de doutorado, que manejavam um orçamento anual de US\$ 8 milhões. Isso era a concretude do sonho do decano Terman que, em 1947, reservara uma parte do Campus para a instalação de pequenas empresas criadas por seus alunos, com o fim de explorarem suas idéias baseadas em P x D da Universidade" (Couvidat e Giusti, 1991). Em 1951, começaram a funcioanar as indústrias no Parque de Stanford de 100 ha., ao lado da Universidade, em Palo Alto. Agregara-se também ao Parque Shockley Semicondutor, dos "pesquisadores do laboratório de telecomunicação do Bell Lab da AT\&T. notadamente os da equipe de um dos inventores do transistor, Richard Shockley". Surge, assim, o primeiro tecnopolo, indutor do Vale do Silício e da "febre tecnopolitana" que mais tarde se espalharia pelo mundo.

Consideramos a região de Boston (Rodovia 128) como produtora de inovações para interesse bélico, apesar de o boom da alta tecnologia em Massachusetts ocorrer, com maior expressão, na fase da crise do fordismo.

Este fato é marcante pelo crescimento das indústrias inovantes numa fase de queda das indústrias têxteis, nos anos 50 e 60 , em face da ajuda massiva dos programas militares e espaciais: aeronaves, mísseis, veículos espaciais, instrumentos e materiais elétricos. Com o fim da Guerra do Vietnam, cessou a ajuda do Estado. Agora o complexo HT da Rodovia 128 atingiria outro estágio, do que trataremos mais adiante.

Seguindo de perto o trabalho de Dorfman (1983), atestamos o papel das firmas inovadoras - DEC, Data General, Wang, Prime e Computervision - no processo caracterizante do Vale do Silício. Essas firmas deram origem à revolução eletrônica do pós-guerra, quase todas fundadas nos anos 50 ou um pouco depois. Os novos empresários vinham da Universidade e de laboratórios, desenvolvendo os primeiros computadores, já nos anos 40. As instituições de pesquisa se voltaram a atender a demanda militar: o Draper Instrumentation Lab. (do MIT), fundado durante a Guerra Mundial, resolveu problemas de orientação e navegação de mísseis balísticos; o Lincoln Lab. aperfeiçoou pesquisa em radar para a Air Force. (p.309).

b) Fase da Guerra Fria - Dada a necessidade de o capitalismo manter vivo e intenso o funcionamento das forças produtivas que mais lhe tragam lucro, após a guerra mundial continuam vivos os interesses por armamentos. Mais ainda porque no rescaldo do grande escombro, fagulhas despertavam incêndios localizados que tinham nos EUA um suposto grande bombeiro, às vezes auxiliados por outros países que mantinham vínculos de domínio em várias regiões do mundo. Ainda, as forças capitalistas internacionais, após 1945, tinham que se por de modo claro e permanente, antagônicas à 
expansão do comunismo ou, mais particularmente, à influência da URSS. E isso se fez sob tensão prolongada, mas não chegando a enfrentamento armado direto. Foi um período de fortes preocupações que dominou o mundo, aproximadamente, entre 1947 e 1975, conhecido na literatura como Guerra Fria. De certo modo, isso se prolongara até final dos anos 80 . No primeiro lustro do pós-guerra, as nações tendiam a um enquadramento à nova realidade internacional: tratado do Rio de Janeiro, Doutrina Truman, Plano Marshall, COMECOM, OTAN, divisão da Alemanha etc. Além do mais, o comportamento político de alguns países reforçava o comunismo na correlação de forças mundiais: a explosão da bomba atômica pela URSS, a vitória de Mao-Tsé-Tung na China continental, a consolidação das Repúblicas Populares na Europa, as lutas internas por liberdades democráticas e por independência em muitos países. Esse despertar pelo novo, por outras condições de vida em todos os continentes, acirrou sensivelmente as forças imperialistas, tão logo enfileiradas na corrida armamentista. A década de 50 começava com a Guerra da Coréia, seguindo-se da criação de um organismo para impedir a expansão do "espectro do comunismo" no sudeste asiático (OTASE ou SEATO em 1954); intervenção da URSS na Hungria (1956) e a Revolução Cubana em 1959 marcaram os mais importantes eventos das tensões na segunda metade do século XX.

Quando se iniciam os anos 60, EUA e URSS dão ao mundo um aceno de paz (Paris, 1960), abafado incontinenti com o caso do avião espião U-2 dos EUA abatido pelos soviéticos. Levanta-se o Muro de Berlin (1961), dá-se partida às viagens espaciais por toda a década, culminando com a chegada do homem na lua. Surge a Aliança para o Progresso. "Progresso" com o fim de oferecer cooperação técnica e financeira à América Latina, para livrá-la do comunismo de Fidel Castro. Em 1968, a URSS invade a Tchecoslováquia, sob pretexto de salvá-la do capitalismo avassalador. Somente nos anos 70 as Grandes Potências tendem abafar a Guerra Fria: acordo nuclear (1971), limitação das explosões nucleares (1974), redução dos mísseis (1972), planos conjuntos de conquistar o espaço sideral (1975) e, enfim, a Declaração de Helsinque (1975), regulamentando a Coexistência Pacífica, aceita pelos dois grandes e por dezenas de outros países. Haveria nisso uma saída da Guerra Fria ou um armistício ante à crise que se abatia sobre o sistema capitalista? $\mathrm{O}$ mundo, de qualquer modo, continuaria vivendo sob as arengas dos detentores de poderosas armas.

Nesse cenário de Guerra Fria e conflitos regionais - especialmente na Ásia e África exigiam-se das pesquisas mais e mais inovações tecnológicas para atender aos numerosos programas bélicos e estratégicos.

Uma equipe de economistas, historiadores e geógrafos soviéticos (Antossiak et alli, 1984: 40) escrevia que "o militarismo contemporâneo distingue-se do do passado pela militarização da economia e da ciência, pela corrida aos armamentos inaudita na história, pelo equipamento das forças armadas com os tipos mais modernos de armas e material bélico, pela fusão intensiva da oligarquia militar com o aparelho dos grandes monopólios". O testemunho de um jornalista (Dixon, 1976: 83), especializado na avaliação do uso da ciência, revela essa condição na Guerra do Vietnam “... engenhos eletrônicos e armas avançadas eram empregadas para detectar, localizar e destruir o inimigo. Computadores eram usados para processar dados sobre as posições e movimentação dos vietcongs e calcular os meios de ataques mais eficientes, que eram então efetuados por uma bateria de armamentos automáticos ou semi-automáticos”.

No início do pós-guerra, a eletrônica fora tomada pelo complexo industrial-militar, prosseguindo seu desenvolvimento na Guerra Fria, como meio de obtenção de cálculos e de respostas às ações com maior rapidez e precisão. Seu uso por outras áreas do conhecimento abriu enorme leque de novas tecnologias e de serviços, definindo o atual paradigma tecnológico que atua no cotidiano de todos nós. 
Para as viagens ao espaço sideral, novos materiais surgiram com as pesquisas, iniciadas em Stanford e levada avante em outros centros renomados, financiados pelo Ministério de Defesa ou por grandes conglomerados financeiros. As ciências de base - Química, Física, Biologia entraram em simbiose nos complexos processos de criação de inovações que irrompiam dos laboratórios das universidades de vários países. Integraram-se centros acadêmicos, com a revolução das comunicações, estabelecendo a divisão internacional do trabalho científico, com centros especializados em biotecnologia, eletrônica, aeroespacial, novos materiais, química fina, mecânica de precisão, robótica.

As condições técnicas em usos possibilitaram a aproximação entre a concepção e a execução, ou seja, a passagem dos resultados das pesquisas para a produção em escala. Verificase, ainda, que o tempo entre o pensar e o fazer estava mais reduzido. A redução desse tempo impunha a redução do espaço entre os dois, a pesquisa e a produção. Onde estivesse mantida essa redução, temporal e espacial, não demoraria a montagem do espaço geográfico do saber superposto ao espaço geográfico fazer, como nos tem mostrado a história.

À medida que novas tecnologias se desenvolviam, com o repasse de elevadas verbas para P x D nos Estados Unidos, numa época de contínuo crescimento econômico, mas de permanente corrida armamentista, ocorria um boom de novos tecnopolos (45 na primeira metade dos anos 60!) nos Estados Unidos.

Tabela 01 - Estados Unidos da América

Criação de Tecnopolos 1951 - 1975

\begin{tabular}{cc}
\hline Anos & tecnopolos criados \\
\hline $1951-55$ & 05 \\
$1956-60$ & 18 \\
$1961-65$ & 45 \\
$1966-70$ & 09 \\
$1971-75$ & 03 \\
\hline
\end{tabular}

Fonte: Autrement, 74, nov. 1985

A mesma observação pode ser feita quando verificamos a criação dos tecnopolos mais dinâmicos nos Estados Unidos. Parece-nos, assim, que há uma correlação entre a emergência dos tecnopolos e as demandas da política armamentista durante a Guerra-Fria, pelo menos nos Estados Unidos.

Tabela 02 - Estados Unidos da América

Criação de Tecnopolos mais Dinâmicos anos 1950 - 1970

\begin{tabular}{cc}
\hline Década & $\mathbf{N}^{\mathbf{0}}$ de Tecnopolos \\
\hline 1950 & 04 \\
1960 & 07 \\
1970 & 01 \\
\hline
\end{tabular}

Fonte: Autrement, 74, nov/1985 


\section{c) Em busca da saída da crise.}

Vimos um pouco antes que, ao meio da década de 1970, o palco da Guerra Fria começava a desmontar-se. O avanço do comunismo não era mais temeroso para os países capitalistas. Em parte, fora resolvido com a "coexistência pacífica", mas também os países do bloco socialista enfrentavam grandes e fortes preocupações internas: descontrole da economia, pressões sociais por liberdades individuais, crises políticas, atraso técnico-científico. Isso dava fôlego ao mundo capitalista por redobrar seus esforços ante à crise que se aguçava nos anos 70 e 80 .

Diante da recessão e suas consequências, empresários e governo se empenharam na busca de saída da crise. Do lado das empresas, intensificaram-se as medidas para aumentar a competitividade; por parte do Estado, a capacitação dos recursos humanos e de captação de inovações.

É consenso entre vários estudiosos e instituições, como a OCDE (Salomon, 1989: 30), que desenvolver o sistema de pesquisa e difundir as descobertas e invenções é uma das armas para ganhar a batalha da competitividade, conquistar e conservar novos mercados.

Nesse aspecto, para o sociólogo Joseph Bem-David, "os bons resultados do modelo americano se deviam a 2 fatores: de um lado a capacidade das estruturas Universitárias de se adaptarem às necessidades novas nascidas da ciência e, de outro lado, a capacidade do tecido industrial de explorar mais eficazmente os resultados da pesquisa" (Salomon, 1989: 33).

Os países europeus passaram a adotar o modelo que engloba educação, pesquisa, indústria e comércio exterior para assegurar o dinamismo das empresas no plano mundial, competindo inclusive com os norte-americanos, a partir dos anos 70.

Por parte dos japoneses, a batalha pela competitividade é, ainda, mais forte e intensiva, como se pode constatar em Ishiara (1991). Em uma de suas exaltações nacionalistas, este Autor trata do nível da tecnologia de seu país: "Qual é a fonte do novo dinamismo japonês? Na superfície, é nossa cultura de alta tecnologia e nosso estilo de vida. A mola principal, naturalmente, é a nossa tecnologia industrial, que está a frente até dos americanos” (p. 62). Mais adiante, Ishiara reconhece a liderança dos E.U.A. na pesquisa básica, embora para ele "a competitividade ficará para quem souber utilizar os resultados das investigações (pesquisas) no sistema produtivo, como fazem os japoneses... Mas, brilhantes descobertas de laboratórios são inúteis até que engenheiros e os operadores dos tornos mecânicos as convertam em produtos. Ligando a torre de marfim à linha de montagem, o know how japonês contribuiu para a economia mundial" (p. 116).

Desde o final dos anos 70, os japoneses entraram na competição dos mercados internacionais de semicondutores, para, uma década depois, atingirem a posição de país com maior índice de inovação noutros setores (Vogel, 1990). Para liderar outras áreas da C e T, o governo japonês lançou, nos anos 80 , três grandes programas: investigação exploratória para tecnologia avançada (ERATO), projeto de investigação e desenvolvimento de tecnologias básicas para futuras indústrias e o Centro de Tecnologia Chave. Esses programas englobam pesquisas avançadas de biotecnologia, novos materiais, óptica eletrônica, sistema de informação e comunicação, dentre outros. Já vimos que na década de 60 os europeus estavam aptos a acompanhar os norte-americanos. Estes, por sua vez foram pioneiros com as experiências dos parques técnico-científicos em que se demonstrara o papel positivo das relações entre instituições de formação e pesquisa e o setor produtivo, na geração de novos processos e bens. 
Esse aprendizado aderiu, rapidamente, ao tecido sócio-político-econômico europeu e japonês, através da adoção de políticas de $\mathrm{C}$ e $\mathrm{T}$, como instrumento de desenvolvimento regional, para tentar abater os efeitos nefastos da crise que, inicialmente, se alastrara pelos países desenvolvidos (Benko, 1991; Salomon, 1989).

Espelhados nos casos do Silicon Valley e de algumas regiões dos E.U.A., vários países europeus e, posteriormente o Japão, decidiram-se pelo modelo tecnopolo.

Embora algumas iniciativas tenham nascido na década anterior - Tsukuba, SophiaAntipolis, ZIRST de Meylan - somente na segunda metade da década de 70 e nos anos 80, a "febre dos tecnopolos" tomou conta da Europa e entrou no Extremo Oriente. Alguns desses polos são clássicos: Sophia-Antipolis (primeiro da Europa), de Meylan-Grenoble na França; o Cambridge Science Park e o Heriot-Watt University Research Park na Grã-Bretanha; o Electrum Stokolm na cidade nova de Kista, a $15 \mathrm{~km}$ da Capital, considerada o "Silicon Valley" da Suécia; Louvain-la Neuve, na Bélgica, tornaram-se modelo para o que vieram depois. Portanto, o momento atual do período técnico-científico é marcado pela corrida à alta tecnologia para sair da crise, tendo como instrumento organizacional o tecnopolo.

Situaríamos, nesse caso, aquele que Certaines (1988) considera como pólos de reconversão e pólos de desenvolvimento, conceito este, recentemente, desenvolvido por DeBresson (1989). Certaines diferencia-os, dando ao segundo tipo o caráter de tecnopolo nascido em centro não tocado pela crise das indústrias fordistas, estando mais orientado para a construção do futuro a partir das novas tecnologias, utilizando o potencial universitário presente, substrato este tomado por DeBresson para elaborar seu ensaio sobre o pólo tecnológico de desenvolvimento.

O relatório de Bruhat (1990) deixa claro que os tecnopolos franceses foram inspirados, ainda nos anos 60, no exemplo da Rodovia 128 em Boston e fundamentados na teoria perrouxiana das indústrias industrializantes, especialmente com $\mathrm{o}$ advento das novas tecnologias. Assim é que os políticos, calcados no modelo de desenvolvimento dos 50 e 60, foram incentivados a visitar tecnopolos americanos como meio de melhor orientar os projetos de desenvolvimento local e regional de seu país.

Na Alemanha (Sternberg, 1989), os tecnopolos ou centros de inovação, a partir dos anos 80 orientavam-se ao desenvolvimento local que seria induzido pela atração de subsidiárias de grandes grupos.

No Japão, o Programa Tecnopolis de 1982 faz parte dos esforços de planejamento e política de desenvolvimento regional que vem desde dos anos 50, para integrar regiões estagnadas no dinamismo da economia nacional. Para isso, os planejadores seguiam as linhas básicas das idéias de Perroux, e as experiências das indústrias de alta tecnologia dos Estados Unidos (Glasmeier, 1988). No Japão como em França, a referência à ideia dos pólos de desenvolvimento se restringia apenas ao modelo e não à teoria de Perroux, isto é, ter no tecnopolo um elemento mobilizador de recursos, aproveitando a emergência de novos setores e a nova organização da produção, no quadro de outros elementos da política regional, como a implantação de infra-estrutura e habitação.

Nos EUA, segundo o secretário da missão Interuniversitária de Coordenação das Trocas Francoamericanas, "a proposta principal dos anos 80 e 90 é o desenvolvimento mais harmoniosos, no plano regional, do conjunto do tecido industrial se social, sem que jamais se perca de vista o contexto da concorrência internacional. O tecnopolo deve se inserir no conjunto mais vasto que mobilize todos os recursos materiais, humanos e financeiros" (Dommengues, 1985: 61). 
Retornando ao caso japonês, nos anos 60 e 70 a concepção da cidade-científica de Tsukuba se voltou muito à política de descentralização, o que não deixa de ser um indutor de integração do antigo espaço rural à região metropolitana de Tóquio. Para a efetivação do Projeto Tecnopolis - que desenvolveremos adiante - dentre outros fatores, Broadbent (1990) inclui os esforços do governo japonês, a fim de reverter o êxodo de empresas para outros países, em grande parte Coréia, Taiwan e Estados Unidos, estimuladas pelos incentivos fiscais, centros de produção mais baixos e mercados (Futuribles, junho, 1989).

Como estes pólos de desenvolvimento de inserem, espacial e temporalmente, no contexto de fase recessiva do ciclo atual, eles não se excluem do mesmo objetivo dos pólos de reconversão das "regiões sinistradas".

\section{d) Eco de Uma demanda}

Vê-se que a expansão dos tecnopolos nos vários países dá-se paralelamente à crise do fordismo e, simultânea à difusão internacional das novas tecnologias, impulsionadas pelas multinacionais. Esses dois fatos em muito contribuíram para a relocação de muitas empresas e/ou de seus departamentos em forma de PMEs, bem como o assentamento de novas firmas HT em diferentes locais do mundo mais propícios aos aproveitamentos de novas vantagens comparativas. Os lugares preferidos eram aqueles que ofereciam condições adequadas à pesquisa e de meios para melhor interligação com os demais fabricantes da linha do produto e com os mercados nacional e internacional. Daí darem prioridade às cidades situadas em nós de comunicação, próximas a aeroportos com boas condições ambientais e infra-estruturais.

Além do mais, com as novas invenções reduziu-se o ciclo de vida dos produtos, pondo em risco as indústrias de produtos maduros ou altamente padronizados, cujas regiões entraram no processo de desindustrialização. Para se reestabelecerem e absorverem novos processos e/ou criarem novos produtos e se reporem no cenário mercadológico dominante, as indústrias buscam os centros e as regiões de maior densidade de conhecimento, de pesquisa, de capacidade inovadora. Nessa demanda tomam maior peso os lugares ricos em laboratórios, em universidades, em cérebros, em força de trabalho qualificada (Malecki, 1979). A intensidade desses critérios varia com as estratégias relativas à linha de produção.

Com a revoada dos quadros técnicos das grandes firmas, devido à externalização de algumas funções, surgiram PMEs especializadas de base tecnológica, cuja localização mais adequada são os parques científicos. Ademais, nesses locais, se agregarem negócios e serviços baseados nas novas tecnologias, como a área de computação e informação, além de uma elevada densidade de pessoal qualificado, pesquisadores, engenheiros e técnicos.

Tomemos, como exemplo, a Cité Scientifique d'Île-de-France-Sud. Além do reconhecido potencial técnico-científico - $43 \%$ do conjunto dos laboratórios, $60 \%$ das grandes escolas do País e 2 universidades de reputação internacional - os tecnopolos dessa região francesa situamse em entroncamente rodo-ferroviário moderníssimo e nas proximidades do aeroporto de Orly e com fácil acesso ao aeroporto Charles de Gaulle, o que lhes favorece ligação com o mundo. Além do mais, estão no entorno de Paris as villes nouvelles - Evry, St. Quentin-en-Yvelines exibindo elevado marketing de modernidade, atração por excelência de filiais de grupos estrangeiros e PMEs com funções de P x D (Carroue, 1990). A estratégia das firmas volta-se mais à escolha de "nichos" para inserir-se no mercado internacional, além da recomposição do emprego regional. 
A preferência dos tecnopolos da Cité Scientifique d'Île-de-France-Sud por esse tipo de empresa, segundo Carroue, se deve a alguns fatores próprios à região: evitar obrigações aduaneiras, segurar a clientela, administrar as susceptibilidades nacionais, permanecer próximo dos mercados.

Manzagol (1990) raciocina, no caso dos centros HT, que a natureza das produções liga-se à estratégia das firmas que pesam no destino dos complexos territoriais, comprovado com uma série de exemplos. A ação da Motorola em Phoenix (E.U.A.) deu uma fisionomia particular à Cidade, deixando o setor de fabricação dos circuitos integrados no México e no ExtremoOriente; diferentemente, "no Silicon Valley uma boa parte dos circuitos integrados se faz em pequenas séries"; em Kyushu, no Japão, a montagem automatizada é feita com a mão-de-obra de baixo salário (Fujita, 1988).

Naqueles lugares que já agregaram ampla gama de serviços e de PMEs, exemplificados pelos tecnopolos de áreas metropolitanas, eleva-se a demanda por parte das grandes firmas, porquanto aí estariam potenciais fornecedores de equipamentos, de componentes e um amplo e complexo mercado de trabalho. Em 1988, Certaines dizia que o "termo tecnopolo evoca a centralização de meios técnicos", dando a um lugar uma alta capacidade de atração de atividade e centralidade.

Desse modo, com a intensidade da demanda, acentua-se a polarização, isto é, o tecnopolo fermenta a capacidade técnica que tende à expansão, a quebrar os limites, tanto com a expansão territorial das tecnologias novas a desenvolver trocas e formar tecno-redes, "novas formas de redes urbanas" (Jalabert, 1990), em diferentes países. 


\section{A territorialização dos tecnopolos}

Desde o início dos anos 50, os tecnopolos vêm se instalando em lugares onde aquelas condições, estudadas no capítulo 3, se encontram presentes.

Decorridas quatro décadas desde a implantação do primeiro tecnopolo, o fenômeno hoje é global, pois estão demarcados no Atlas Internacional (Couvidat e Giusti, 1991) cerca de 129 tecnopolos distribuídos pela América, Oceania, Ásia e Europa; Certaines (1988) cartografou 74 deles em funcionamento só na Ásia e Europa e mais 27 em implantação na França.

$\mathrm{Na}$ abertura do Encontro Latino-americano para o Desenvolvimento de Empreendimentos de Base Tecnológica, no Rio de Janeiro, em maio de 1993, Pertti Huuskonen, vice-presidente da Internacional Association of Science Parks indicou que no mundo há 650 parques tecnológicos (300 só nos EUA), a maioria situado em torno de Universidades, empregando 500 mil trabalhadores em 11 mil empresas, esperando que no final do século haja aproximadamente mil desses parques. Para esse executivo, "trata-se de um fenômeno global, no qual o único continente que não tem parques tecnológicos é a Antártida, apesar de já estarmos pensando em promover empreendimentos também naquela região" (Gazeta Mercantil, 28/05/93).

Em face da existência desse novo tipo de meio técnico-científico, tratamos, nesta parte de nosso estudo, de sua territorialização nos Estados Unidos da América, no Japão, na Europa e no Brasil, como fato concreto.

Numa outra escala com maior detalhamento, estudaremos o pólo tecnológico de São Carlos, no interior de São Paulo, como meio de melhor compreender o processo que explicitamos no capítulo 3.

\subsection{A territorialização dos tecnopolos nos Estados Unidos da América.}

Dada a especificidade do país líder do mundo capitalista, os EUA territorializam os tecnopolos em todo o percurso do período técnico-científico, embora com maior ênfase nos momentos de maior demanda por parte dos interesses militares (veja item 3.4), de acordo com as contingências históricas e político-econômicas.

É no ambiente da economia dos anos 50 que surgem, nos EUA, os espaços tecnopolitanos. Somente duas décadas depois, esse tipo de organização espacial e produtiva toma expressão e se dissemina por várias regiões, servindo de modelo a outros países.

Antes de pontuarmos os casos mais exemplares, alguns esclarecimentos julgamos necessários: por que é nos Estados Unidos que surgem os tecnopolos? Que determinantes conduziram o processo de formação desses novos espaços nos EUA? Qual o papel do espaço pré-existente no vigor desses determinantes? Que elementos substanciam a existência dos tecnopolos nos EUA? Onde se localizam os casos mais destacados?

Sabendo que nos EUA implantou-se a fundamental base tecnológica da $2^{\mathrm{a}}$ Guerra Mundial (Braverman, 1987: 145), especialmente em torno da baía de São Francisco e no manufacturing belt, 
além de deter grande parte do capital mundial e de agregar um significativo contingente de cientistas do mundo inteiro, pode-se compreender a presença das condições mais propícias a responder aos problemas emergentes durante a última Guerra Mundial.

A história do grande conflito entre nações tem mostrado que a maior das oficinas dos arsenais de destruição, os mais importantes centos de pesquisa e de produção das armas modernas (aviões, mísseis, bombas atômicas etc.) estavam na América do Norte. As hostilidades no Pacífico estimularam a pesquisa e o desenvolvimento armamentista na costa oeste, onde se enfileiram poderosas bases militares, destacadas indústrias vinculadas à produção armamentista, bem equipados laboratórios apoiados pelo Departamento de Defesa - DOD -, serviços por cientistas de renome.

Nesse ambiente surge um distrito marshaliano, junto ao Campus da Universidade de Stanford. A experiência, restrita à Califórnia, não se ampliara, nacionalmente, de imediato, mas não se extinguira, reservando-se, de início, ao amplo marcado militar-estratégico e como atração de trabalhadores. Em Palo Alto, nos anos 50, se materializara um pequeno esboço ou núcleo irradiador do que iria ocorrer nas décadas seguintes em escalas nacional e mundial, como condensação das atividades P x D.

Ao governo dos EUA, com a destinação de verbas, coube a tarefa de estabelecer a orientação locacional dos complexos industriais, à medida que alocava os equipamentos de $\mathrm{P} x$ $\mathrm{D}$ de interesse militar para as regiões oeste e sul: "terras disponíveis à edificação, proximidade a bases militares (e distanciamento da força-de-trabalho organizada e militante) são fatores básicos que explicam a orientação das indústrias americanas voltadas a interesse militar. Esses fatores têm atraído fortemente grandes indústrias do sistema militar para o sunbelt e, em menor escala, para lugares periféricos do manufacturing belt. Atraída a mão-de-obra, esta serviu, em seguida, para atender as novas e antigas indústrias de suprimentos, nesses centros (Markusen e Bloch, 1985: 114).

Ao manter-se o clima beligerante, psicológica e concretamente, as bigornas norteamericanas mantinham-se ativas, exigindo inovações e maior criatividade na elaboração das armas inteligentes, manobradas, crescentemente, por artefatos eletrônicos. Esse mercado suportava e punha a seu serviço ampla e capacitada rede de P x D movimentada pelos melhores cérebros do mundo, às custas do Departamento de Defesa dos EUA. Em 1986, dos US\$ 50 bilhões do orçamento federal para $\mathrm{P}$ x D, 72\% se destinavam à pesquisa militar (Derian, 1987b). Essa prioridade do governo vem de décadas (Malecki, 1982: 21). Das 10 regiões metropolitanas, relacionadas no estudo desse Autor, que mais receberam recursos para P x D de universidades, somente 2 não estão entre as 15 que mais polarizavam recursos para $\mathrm{P}$ x D da Defesa, em 1977. Em 1965, dó 3 não se incluíam.

O circuito militar-industrial, além dos organismos a eles específicos, agrega empresas privadas, cujo planejamento estratégico segue de perto os programas e projetos militares: Rockwell International, Lockheed, General Electric, Hughes Aircraft, General Dinamics, Boeing, Western Electric, Douglas Aircraft, Motorola etc., comumente assentadas próximo às instalações militares no sul da Califórnia, Baía de São Francisco, Boston, Phoenix etc. (Malecki, 1982; Manzagol, 1987; Markusen e Bloch, 1985).

Mesmo com a crise a partir dos anos 70, têm-se elevado as despesas com a defesa, em detrimento dos demais setores (Gráfico 01). 


\section{ESTADOS UNIDOS DA AMÉRICA}

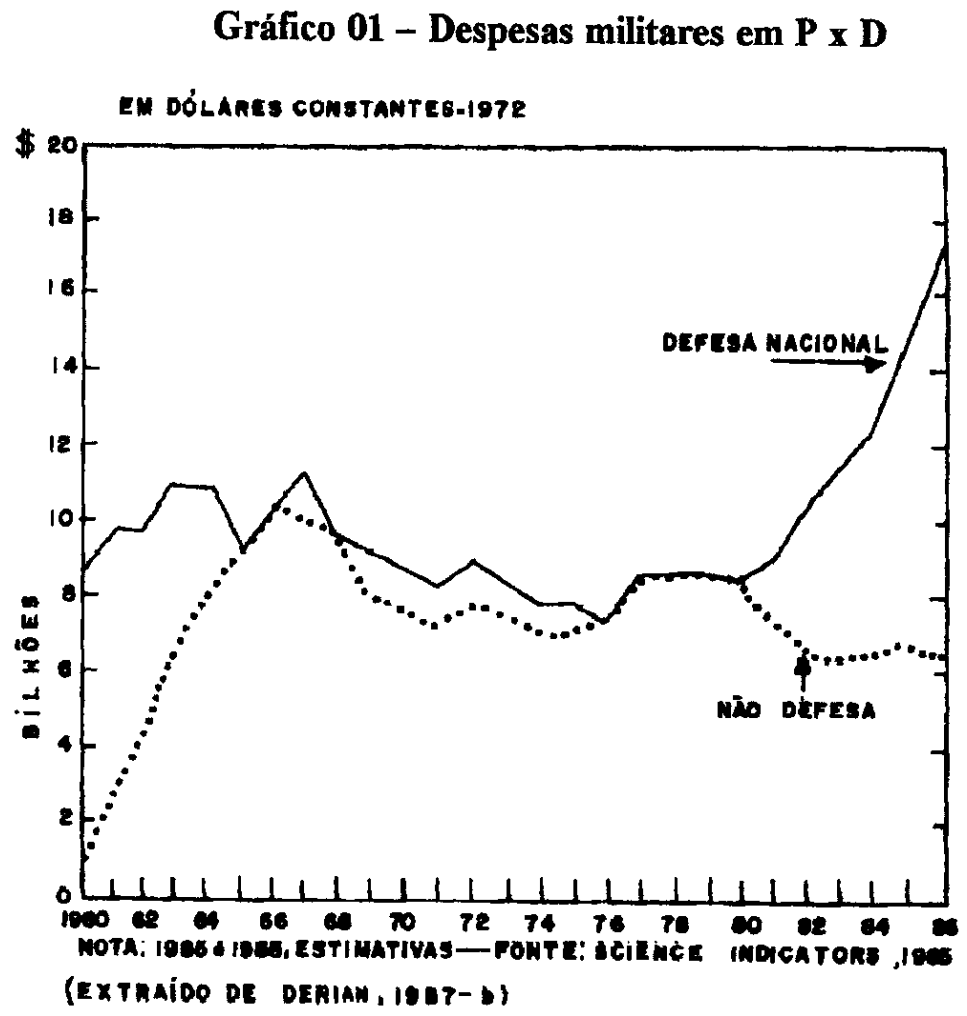

Por sua vez, ante às incertezas, na atual fase recessiva que dominam os negócios, e frente à magnitude da competição interna e externa, as grandes empresas têm procurado, dentro do planejamento estratégico (Malecki, 1980: b) se engajar na busca de inovações, dando prioridade aos esforços de P x D, "valorizando" os resultados das pesquisas acadêmicas através de pequenas firmas spin-off que lhe são dependentes. Esse comportamento, muito imposto pelas novas tecnologias e condições organizacionais, tende a conduzir à elevação da produtividade e maior competência do domínio dos mercados. No decorrer dos anos 80 , estruturas de interface entre o sistema universitário e a indústria estão se multiplicando pelos EUA em todos os ramos da alta tecnologia, conforme estudo de Derian (1987- b).

Partícipes da montagem da primeira engenharia industrial do mundo, os EUA poderam acumular ricas experiências tecnológicas, edificar formas e equipamentos a serviço da vida produtiva e da sociedade. Além disso, várias gerações teceram nos EUA um ambiente técnicocultural com os mais matizes capazes de absorver os novos tons da atual modernidade. Nas novas feições revelam-se as "rugosidades" do passado, como "restos de uma divisão de trabalho internacional, manifestada localmente por combinações particulares do capital, das técnicas e do trabalho utilizado" (Santos, 1980: 136). Isso quer dizer que não teríamos a afamada Rodovia 128 HT de Massachusetts sem a história do manufacturing belt; as universidades do Oeste e, portanto, o Vale do Silício, se ligam às migrações e lutas do século XIX, ou seja, o espaço préexistente revigora os determinantes dos novos espaços da produção pós-fordista dos EUA.

Para a eficácia da construção de um espaço novo para novas necessidades, nem sempre se abandona os velhos espaços, os espaços industriais pré-existentes.

Não era da irradiante insolação ou das fulgurantes paisagens e da tranquilidade dos ambientes isolados do sunbelt que vinham os elementos substantivos da consolidação dos tecnopolos americanos. 
Havia para isso, um encontro íntimo entre demanda por inovações, aumento do grau de competividade entre as nações, aglutinação de investimentos em P x D e de conhecimentos técnico-científicos, nova organização do trabalho. Do amálgama desses elementos se elaborou um modelo que "constituiu provavelmente um dos melhores trunfos dos EUA na corrida tecnológica" (Derian, 1987-b).

Além de uma nova história tecida na ideologia do capitalismo durante séculos com o protestantismo, os EUA mantiveram o papel de receptáculo da emigração de cérebros de vários recantos do mundo, em especial da Alemanha e da Itália durante o domínio nazi-fascista. Uma das constatações desse fato é a participação de vários cientistas estrangeiros na conquista do Prêmio Nobel, em nome dos EUA, a partir de 1945, cujas pesquisas avançadas em Física, Química, Fisiologia e Medicina deram ao País a supremacia tecnológica e científica no mundo, elevando mais ainda o renome de muitas universidades.

\section{Tabela 03 - PRÊMIOS NOBELs $1901-1987$}

\begin{tabular}{l|r|r|r|r|r|r}
\hline \multirow{2}{*}{\multicolumn{1}{c|}{ País }} & \multicolumn{2}{|c|}{ Física } & \multicolumn{2}{c|}{ Química } & \multicolumn{2}{c}{ Fisiologia e Medicina } \\
\cline { 2 - 7 } & Absoluto & $\%$ & Absoluto & \multicolumn{1}{c}{$\%$} & Absoluto & \multicolumn{1}{c}{$\%$} \\
\hline Estados Unidos & 49 & 40,2 & 33 & 30,1 & 59 & 41,2 \\
\hline Grã-Bretanha & 18 & 14,7 & 20 & 18,3 & 21 & 14,7 \\
\hline Alemanha & 17 & 14,1 & 23 & 21,1 & 13 & 9,1 \\
\hline França & 8 & 6,5 & 7 & 6,4 & 9 & 6,3 \\
\hline Outros & 30 & 24,5 & 26 & 24,1 & 41 & 28,7 \\
\hline Total & 122 & 100 & 109 & 100 & 143 & 100 \\
\hline
\end{tabular}

Fonte: 1. Enciclopédia Mirador Internacional - vol. 15, p. 8.105 2. Almanaque Abril - 1989 - p. 367

No item 3.1 vimos o papel da Universidade na reprodução do capital e, portanto, no construto tecnopolitano (item 3.2). Como esses espaços da produção se formam com firmas mais sofisticadas induzidas pela proximidade a centros universitários, é possível admitir a teoria da filtragem ou filter-down theory, adotada por Howell (1984: 14): “firmas e fábricas localizadas em áreas periféricas ou suburbanizadas são menos sofisticadas tecnologicamente do que estabelecimentos localizados em centros urbanos maiores e/ou mais urbanizados e regiões centrais".

Seguindo essa hipótese, relacionamos com base em várias fontes (Malecki, 1982; Benko, 1990; Couvidat e Giusti, 1991; Autremente, 1985) cerca de trinta centros urbanos de dimensões variadas em diferentes estados dos EUA, alguns já bem conhecidos por sua elevada densidade de instituições ensino e pesquisa, outros são relatados na literatura como lugares metropolitanos (Tabela 04). 
Tabela 04 - ESTADOS UNIDOS DA AMÉRICA - INSTIRUIÇÕES ACADÊMICAS (IAs)

Total em Cidades e seu Estado - Total com Doutorado e em Engenharia e Ciências

Aplicadas

\begin{tabular}{|c|c|c|c|c|c|c|}
\hline \multirow{3}{*}{ Cidade } & \multirow{3}{*}{ Estado } & \multicolumn{2}{|c|}{ Total de IAs* } & \multicolumn{3}{|c|}{ Doutarado na Cidade ** } \\
\hline & & \multirow[t]{2}{*}{ Estado } & \multirow[t]{2}{*}{ Cidade } & \multirow[t]{2}{*}{ IAs } & \multicolumn{2}{|c|}{$\begin{array}{c}\text { Em Eng. E Cienc. } \\
\text { Apl. }\end{array}$} \\
\hline & & & & & IAs & Cursos \\
\hline 1 - New York & New York & 187 & 32 & 11 & 7 & 28 \\
\hline 2 - Chicago & Illinois & 79 & 25 & 8 & 7 & 27 \\
\hline 3 -Boston & Massachusetts & 68 & 18 & 8 & 4 & 15 \\
\hline 4 - Philadelphia & Pensylvania & 106 & 17 & 7 & 7 & 26 \\
\hline 5 - Los Angeles & California & 127 & 15 & 7 & 2 & 32 \\
\hline 6 - Baltimore & Maryland & 34 & 15 & 10 & 5 & 25 \\
\hline 7 -Mineapolis-Saint Paul & Minesota & 35 & 14 & 3 & 1 & 16 \\
\hline 8 -Dallas-Austin-F. Worth & Texas & 86 & 13 & 5 & 6 & 31 \\
\hline 9 - Atlanta & Georgia & 45 & 11 & 4 & 2 & 25 \\
\hline 10 - San Francisco & California & 127 & 10 & 4 & 2 & 2 \\
\hline 11 - Houston & Texas & 86 & 8 & 5 & 3 & 25 \\
\hline 12 - Seatle & Washington & 25 & 7 & 3 & 2 & 16 \\
\hline 13 - San Diego & California & 127 & 6 & 5 & 2 & 10 \\
\hline 14 - Raleigh-Durhan & Carolina do Norte & 53 & 6 & 2 & 3 & 23 \\
\hline 15 - Detroit & Michigan & 54 & 5 & 2 & 2 & 19 \\
\hline 16 - Colorado Spring & Colorado & 24 & 5 & 1 & 1 & 3 \\
\hline 17 - Honolulu-Oahu & Hawai & 7 & 4 & 2 & 2 & 12 \\
\hline 18 -Oklahoma & Oklahoma & 25 & 4 & 2 & 1 & 15 \\
\hline 19 - New Haven & Connecticut & 29 & 3 & 1 & 1 & 8 \\
\hline 20 - Knoxville-Dak Ridge & Tennessee & 45 & 3 & 2 & 1 & 15 \\
\hline 21 - Cambridge & Massachusetts & 68 & 3 & 3 & 2 & 20 \\
\hline 22 - Madison & Wisconsin & 38 & 2 & 1 & 1 & 16 \\
\hline 23 - Ann Arbor & Michigan & 54 & 2 & 1 & 1 & 18 \\
\hline 24 - Princeton & New Jersey & 44 & 2 & 1 & 1 & 16 \\
\hline 25 - Ithaca & New York & 187 & 2 & 1 & 1 & 18 \\
\hline 26 - Salt-Lake City & Utah & 6 & 2 & 1 & 1 & 18 \\
\hline 27 - Costa Mesa & California & 127 & 2 & 1 & 1 & 2 \\
\hline 28 - Irvine & California & 127 & 2 & 1 & 1 & 8 \\
\hline 29 - Lafayette & Lousiana & 21 & 1 & 1 & 1 & 3 \\
\hline 30 - Chapel Hill & Carolina do Norte & 53 & 1 & 1 & 1 & 5 \\
\hline
\end{tabular}

Fontes: * Peterson's Guide to Four-Year College - 1992; ** Peterson's Guide to Graduate Programs in Engineering and Applied Sciences - 1990 - Princeton, N.J., EUA 
Na representação cartográfica, (Mapa 02) verificamos que uma maior concentração dessas cidades se dá nas regiões de adensamento demográfico mais elevado: Califórnia, manufacturing belt, região dos Lagos ou centro-oeste e sunbelt.

Mapa 02 -

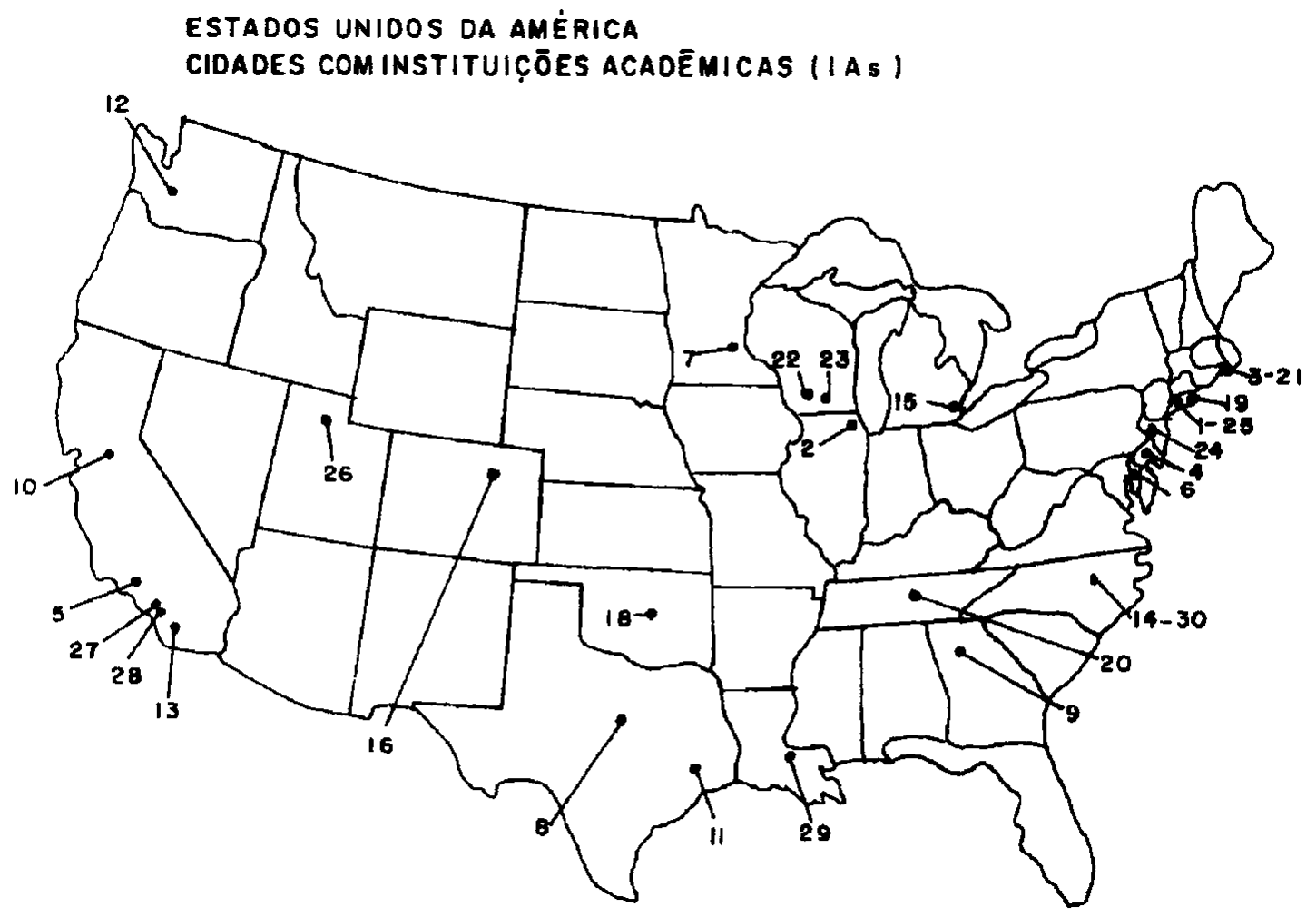

Considerando a segunda coluna da tabela 04 , no conjunto dos Estados com número superior 50 IAs estão aqueles que são a locomotiva do avanço tecnológico atual, onde a presença de tecnopolos se faz com muita ênfase: New York, Illinois, Massachusetts, Pensilvânia, Califórnia, Texas, Carolina do Norte e Michigan. Não é por acaso que neles encontramos as cidades com o maior número de cursos tecnológicos: Los Angeles, Dallas- Austin- Fort Worth e RaleighDurhan, é elevada a proporção entre o número de IAs com doutorado e de cursos tecnológicos, do mesmo modo o número de cursos por IAs. Esse fato aponta para uma possível maior especialização em alguns domínios entre os quais a eletrônica, novos materiais e aeroespacial.

Adicionaremos, ainda, outros dados a espacialização das universidades com maior número superior a 10.000 estudantes e que oferecem doutorado, num total de 133 unidades, apresentado na tabela 05 e no mapa 03. 


\section{Mapa 03 -}

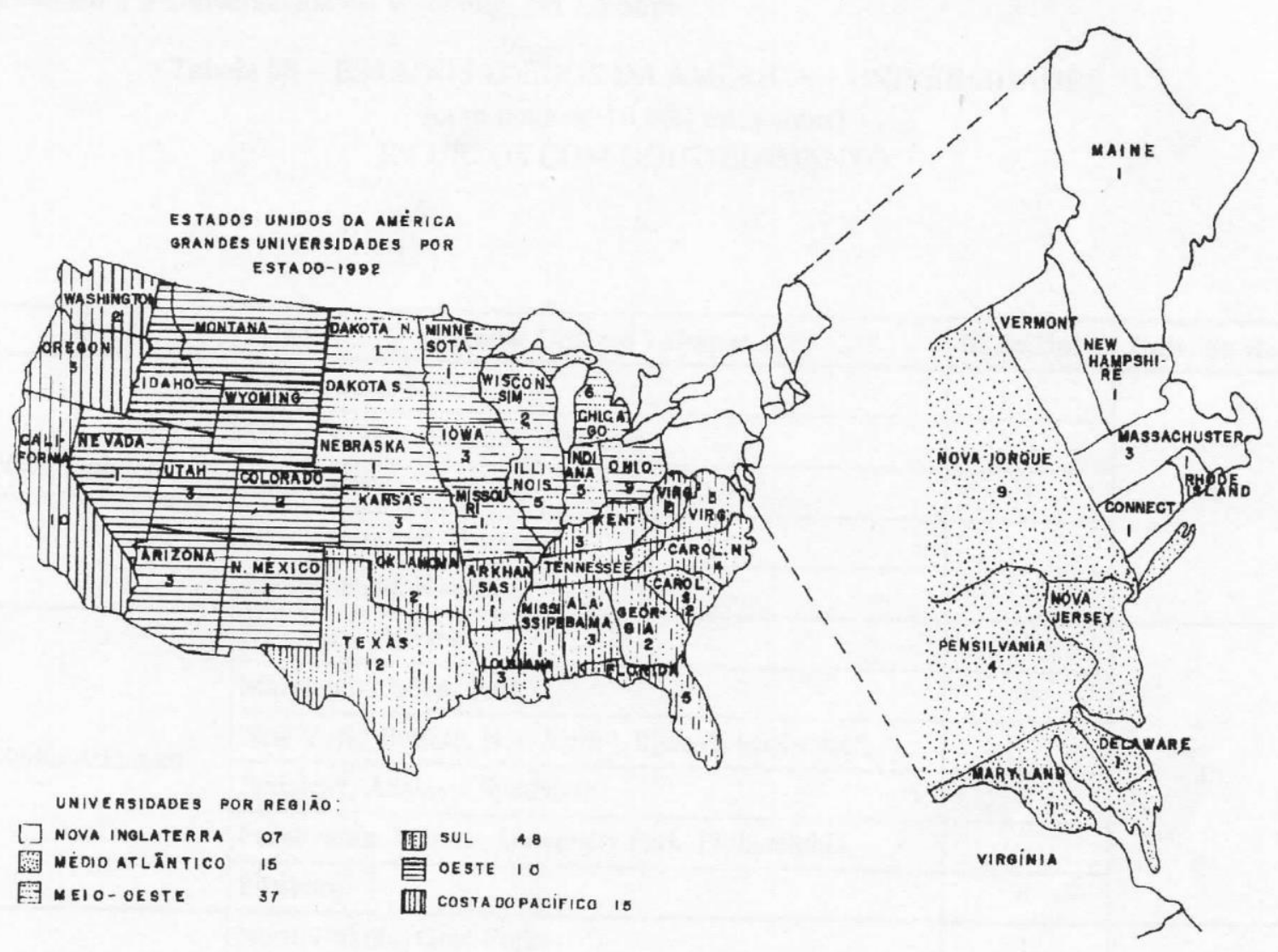

Somente $8,2 \%$ dessas IAs são privadas, tendo-se assim uma dimensão dos investimentos públicos neste setor da $\mathrm{P}$ x D. Das 11 universidades privadas, 7 estão no Estado de New York (3 na City) e as demais em Utah, Texas, Massachusetts e Califórnia.

Excluindo a Universidade do Hawaí, 36,1\% (48 IAs) estão na região do meio-oeste; 11,3\% se distribuem em 4 Estados do Meio-Atlântico, percentual semelhante ao dos três Estados da costa do Pacífico, enquanto instaladas na Nova Inglaterra ou extremo-nordeste são apenas 7 Ias $(5,3 \%)$.

Cinco Estados não dispõem de universidades de porte aqui relacionados:

- Vermont na Nova Inglaterra, malgrado aí funcionem 16 IAs, entre as quais uma com doutorado, mantida pelos recursos públicos para 8.000 estudantes;

- Nova Jersey, no Médio Atlântico, com população superior a 7 milhões de habitantes, tem em funcionamento 44 IAs, 8 delas com doutorado, duas outras sem esse nível, de mais de 10.000 alunos. Metade de suas IAs são públicas. Princeton, uma de suas cidades, está entre os melhores centros de P x D do País, dedicado aos domínios aeroespacial, informação, nuclear, novos materiais, entre outros. As indústrias se concentram na área metropolitana de New York.

-Montana, Idaho e Wyoming são Estados do oeste, com população inferior a um milhão (Wyoming tem $2 \mathrm{~h} / \mathrm{km} 2$ ) e muito dedicados à mineração e agropecuária. Apesar disso, Idaho tem uma universidade pública em Boise com 10.000 estudantes abaixo do nível de doutorado e uma outra com 6.000 alunos 
com esse nível, em Pocatelio. A Montana State University, tem 9.000 alunos e doutorado, em Bozeman, semelhante à Universidade de Wyoming, em Loramie.

\section{Tabela 05 - ESTADOS UNIDOS DA AMÉRICA - UNIVERSIDADES (com mais de 10.000 estudantes) \\ E CURSOS COM DOUTORAMENTO}

\begin{tabular}{|c|c|c|c|}
\hline Região & Estado: Centros Urbanos & $\mathbf{N}^{\circ}$ de Univ & Univ. na \\
\hline \multirow{5}{*}{$\begin{array}{l}\text { Nova Inglaterra ou } \\
\text { Extremo Nordeste }\end{array}$} & Connecticut: Storrs & 1 & \multirow{5}{*}{7} \\
\hline & Massachusetts: Boston*, Amherst & 3 & \\
\hline & Maine: Orono & 1 & \\
\hline & New Hampshire: Durham & 1 & \\
\hline & Rhode Island: Kingston & 1 & \\
\hline \multirow{6}{*}{ Médio Atlântico } & Delaware: Newark & 1 & \multirow{6}{*}{15} \\
\hline & Maryland College Park & 1 & \\
\hline & New York: Buffalo, New York*, Ithaca*, Rochester*, & & \\
\hline & Jamaica*, Albany e Syracusa* & 9 & \\
\hline & Pensilvania: Indiana, University Park, Philadelphia, & & \\
\hline & Pittsburg & 4 & \\
\hline \multirow{17}{*}{ Meio-Oeste } & North Dakota: Gran Forks & 1 & \multirow{13}{*}{37} \\
\hline & Indiana: Nuncie, Terre Haute, Bloomington, Indianopolis, & & \\
\hline & West Lafayette, Lafayette & 5 & \\
\hline & Iowa: Ames, Iowa City e Cedar Falls & 3 & \\
\hline & Kansas: Manhattam, Lawrence, Wichita & 3 & \\
\hline & Michigan Mount Pleasant, Big Rapids, East Lansing, & & \\
\hline & Ann Arbor, Detroit e Kalamazoo & 6 & \\
\hline & Missouri: Saint Loius & 1 & \\
\hline & Minnesota: Minneapolis & 1 & \\
\hline & $\begin{array}{l}\text { Illinois: Normal, De Kalb, Chicago, Cabondale, } \\
\text { Cahmpaign }\end{array}$ & 5 & \\
\hline & Nebraska: Lincoln & 1 & \\
\hline & $\begin{array}{l}\text { Ohio: Bowling Green, Cleveland, Kent, Oxford, } \\
\text { Columbus }\end{array}$ & & \\
\hline & Athems, Akron, Cincinnati e Dayton & 9 & \\
\hline & Alabama: Auburn, Tuscalossa e Birmingham & 3 & \multirow{4}{*}{48} \\
\hline & Arkhansas: Fayeteville & 1 & \\
\hline & $\begin{array}{l}\text { North Carolina: Boone, Greenville, Raleigh e Capel } \\
\text { Hill }\end{array}$ & 4 & \\
\hline & South Carolina: Columbia e Clemson & 2 & \\
\hline
\end{tabular}




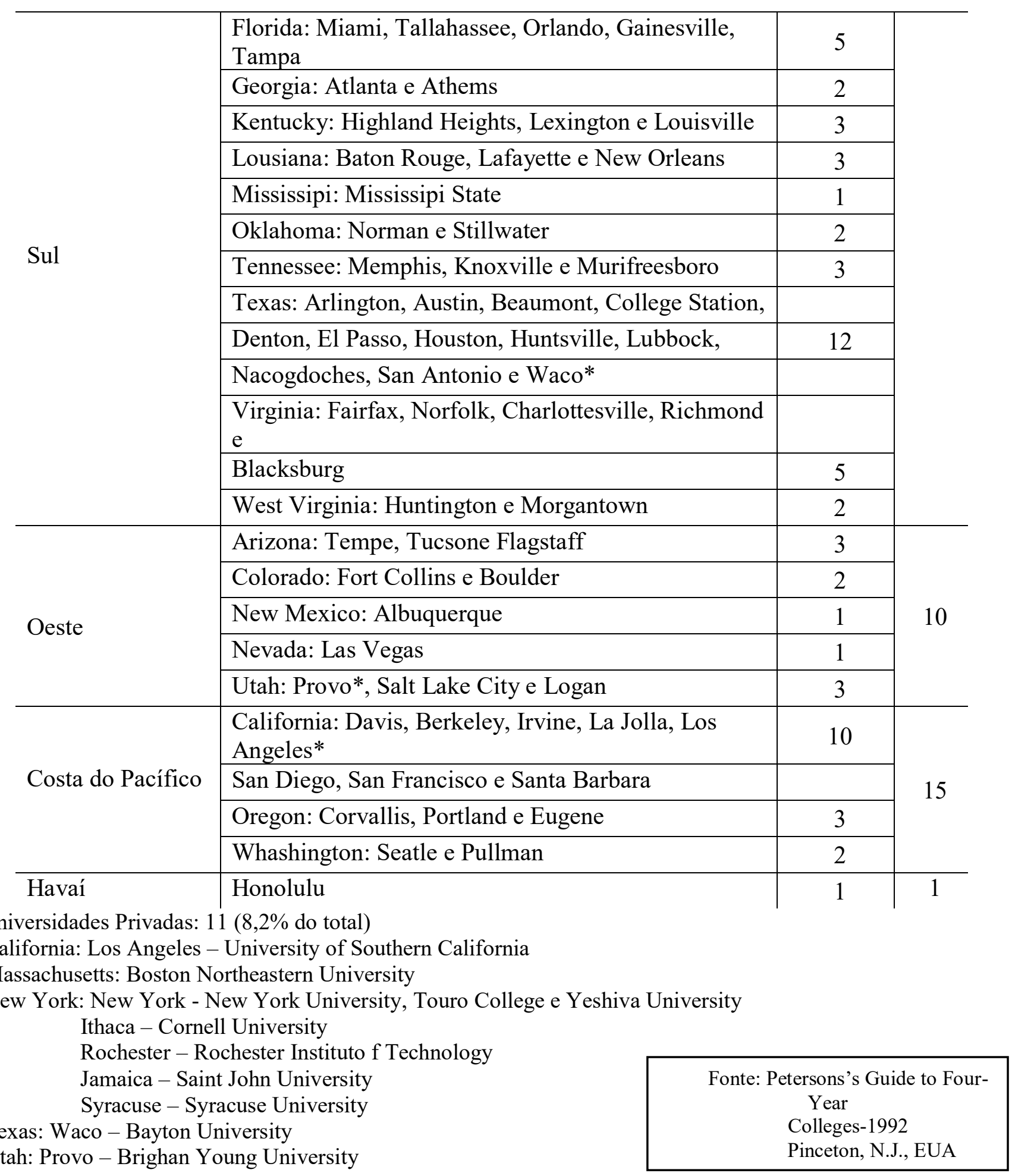

Com essas ressalvas, constata-se a boa dispersão das grandes universidades no território dos EUA, armadura provável para a presença de tecnopolos na quase totalidade dos Estados, embora com maior concentração em algumas regiões que contam com outros fatores favoráveis, tais como os complexos industriais já montados, a exemplo da Califórnia, região 
de Boston, Carolina do Norte e outras, além de inúmeros pontos que estão fortemente conectados com as redes nacional e internacional da alta tecnologia.

Desse modo, em torno das aglomerações maiores- tanto no que respeita à situação demográfica, como em relação às atividades industriais - se solidificaram tecnopolos de maior expressão. Isso não retira das pequenas cidades, especialmente daquelas periféricas às metrópoles com boas condições para "trabalhar e viver"a oportunidade de se engajarem na tecno-rede da região.

Correspondendo às concentrações de $\mathrm{P} \times \mathrm{D}$, de atividades industriais e demográficas, os tecnopolos também se concentram mais nas regiões Oeste e Sul. Dos tecnopolos apresentados pela revista Fortune de setembro de 1983 (Levy, 1990), além de Silicon Valley e do Triangle Research, o Oeste e o Sul contavam mais de 29 tecnopolos, seguidos pelo Nordeste, com 9, além da Rodovia 128.

Desde 1951 vem crescendo o assentamento de tecnopolos nos EUA, intensificando-se na primeira metade dos anos 60, como se nota na gráfico 02. Muitas importantes Universidades se agregam à nova organização da produção-pesquisa como se pode verificar na tabela $06 \mathrm{e}$ no mapa 04. (Cartier e Kerorguen, 1985).

Duas regiões tecnopolitanas merecem referências, tanto pela expressão espacial como pela imagem que elas vêm projetando para o mundo. Refletem-se como modelo de soerguimento da produção e da economia em crise e até outras partes do mundo têm procurado copiar a sua experiência, como indicadoras de uma nova fase A do $5^{\circ}$ Kondratieff.

\section{A - Silicon Valley (Vale do Silício)}

"Silicon Valley has captured the public imagination".

Assim Saxenian (1985) começa seu trabalho que nos põe à frente da cruel realidade social do "símbolo dos benefícios do desenvolvimento comandado pela microeletrônica".

Parece-nos, no entanto, que os erros, as falhas, as distribuições de um projeto como esse têm servido também para o aperfeiçoamento dos demais que hoje se espalham pelo mundo. No exame da experiência do Silicon Valley, Saxenian nos deixa claro não a negação do fato em si, mas como o liberalismo dominante conduziu ao extremo uma das contradições do capitalismo: a elevação das condições econômicas e financeiras das empresas ao lado dos descalabros sociais, com a formação da sociedade dual.

O Vale do Silício fica na Califórnia, que está na borda do Oceano Pacífico, o maio cenário de conflitos do século XX (Segunda Guerra Mundial, Guerra da Coréia, Guerra do Vietnam). Nessa região dos Estados Unidos, se desenvolveram as pesquisas dirigidas aos interesses bélicos nos laboratórios da Universidade de Stanford e das grandes empresas, como a Bell da AT \& T, de onde surgiu o transistor, a maior invenção do pós-guerra, em 1948. Com essa inovação, surge a indústria da microeletrônica, que favoreceu o rápido crescimento da região, o que veio trazer sérios problemas sociais e urbanos. de

$\mathrm{O}$ que antes era ocupado por pomares e fazendas, logo se transforma em áreas industriais,

serviços e de habitação. Entre 1940 e 1975, foram criadas mais de 500.000 empregos e no início da década de 80, só em Santa Clara, havia 480.000 residências. O desenvolvimento urbano e regional tinha agora um caráter particular, diferente do que conhecia: a estrutura 
ocupacional da força-de-trabalho era outra, composta, em alta proporção, por profissionais de alto nível. Isso teve reflexos na organização do novo espaço, que surgia.

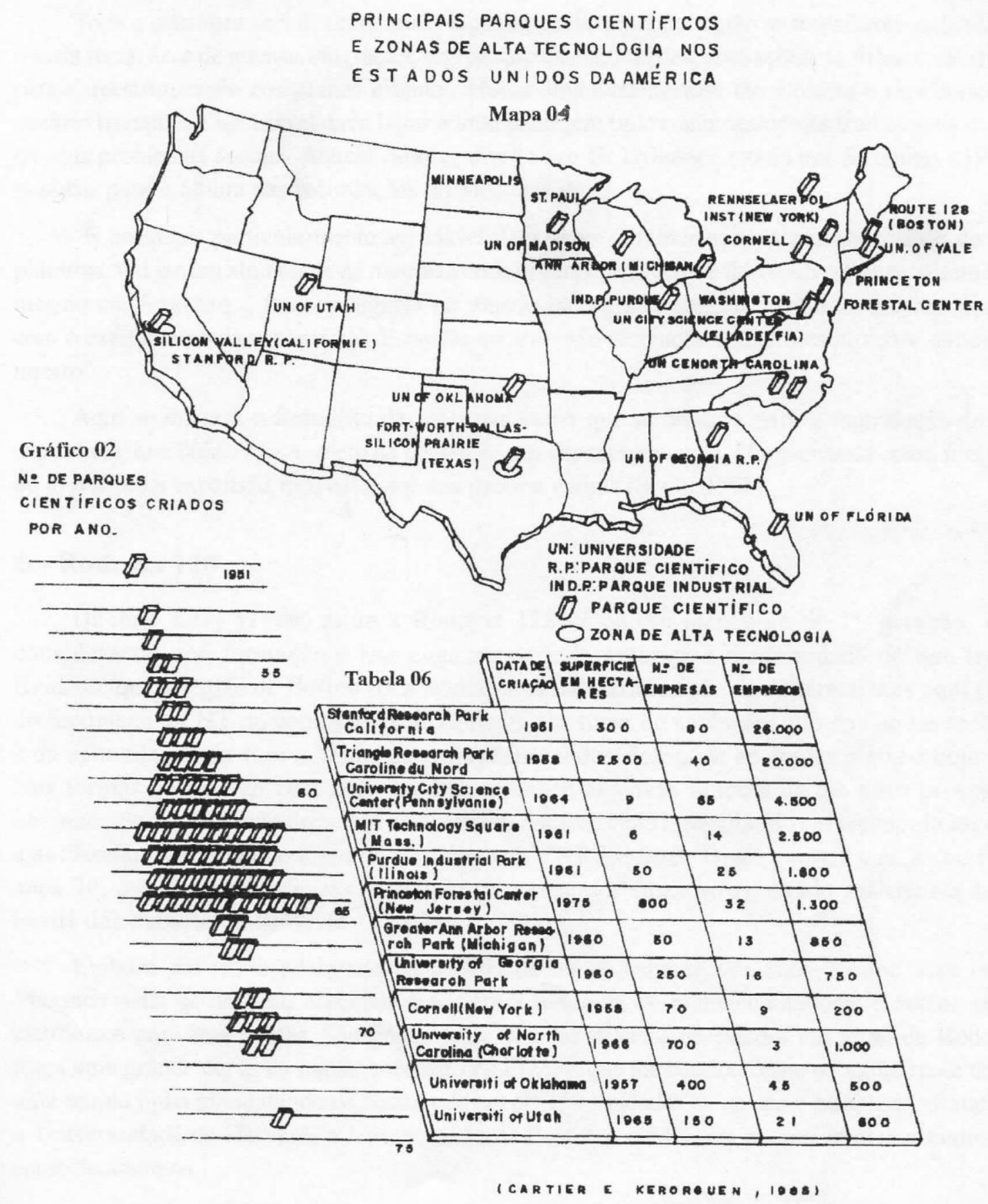


Logo se cria, em 1951, o Stanford Research Park, em torno da Universidade, o primeiro tecnopolo dos EUA, e logo se amplia pelos arredores e por outras cidades da região. Seis cidades se integram, por força da localização de novos parques e das grandes companhias, contando mais de 1.000 empregados: Palo Alto (4), Sunnyvale (10), Mountains View (4), Cupertino (8), São José (2), e Santa Clara (7), ao todo cerca de 35 grandes companhias.

Toda a estrutura social, econômica, espacial e relacional da região se transforma radicalmente: o uso da terra, área de intensa imigração, segregação das habitações, anexações, ao urbano, de territórios rurais, reestruturação dos planos urbanos. Havia uma metamorfose tão violenta e rápida que logo o cenário tranquilo a agradável dava lugar a uma paisagem típica de megalópoles tradicionais com todos os seus problemas sociais. Aquele cântico, escrito por G. Bylinky e citado por Saxenian, (1985: 90), passava para o álbum das recordações do Vale do Silício.

"É um lugar particularmente agradável para viver e trabalhar, uma paisagem linda de colina e planuras, um jardim abundante da natureza onde árvores frutificam e flores silvestres ostentam frescura mesmo em fevereiro... Poucos lugares no mundo tão agradavelmente misturam deleites prazerosos com o excitamento da urbanidade. Esportes ao ar livre e recreação constituem atrações durante o ano inteiro".

Aqui se iniciará a formação de novo panorama que se armaria para a reprodução do sistema capitalista, que houve avança célebre na ocupação dos espaços em crise, "funcionando como foci maiores de inovações e expansão industrial por sua própria conta" (Scott, 1988).

\section{B - Rodovia 128}

Quando Levy (1986) situa a Rodovia 128 como um tecnopolo de $1^{\circ}$. geração, ele está considerando sua formação e seu auge no período anterior à modernidade, de que tratamos. Evidente que a região de Boston foi a primeira na industrialização da América, mas aqui tratamos do fenômeno da HT no contexto da atualidade. Da soma do conhecimento das novas tecnologias e da acumulação da fase anterior do capitalismo industrial, pôde se erguer o que é hoje Boston. Nas formas antigas do rust belt, estabeleceram-se as novas funções de um novo processo com um modo de organização diferente ao anterior (Santos, 1985), resultando em tecnopolo espontâneo e autônomo. Um pequeno texto do sociólogo do CNRS, Marco Diani, mostra que, só no final dos anos 70, é que o governo veio participar com recursos financeiros, dando assistência às PMEs locais das cidades da Rodovia 128 (Diani, 1985).

Embora em ritmo acelerado na década de 60, é somente nos anos 70 que essa região de Massachusetts se destaca, especialmente com a indústria de microcomputadores e outros aparelhos eletrônicos para uso militar. São pouco mais de duas dezenas de cidades em torno da Rodovia que traça uma grande curva na região nordeste dos EUA, o que lhe batizou como o "semicírculo dourado", uma ampla linha circundando os centros do saber: 150 unidades de ensino e pesquisa, destacando-se a Universidade de Harvard, a Universidade de Boston e o MIT em meio a mitos outros estabelecimentos.

$\mathrm{Na}$ década de 1980, a região contava com 1.200 firmas de HT que ocupavam mais de 200.000 pessoas, destacando-se algumas empresas tradicionais no ramo de computadores: DIGITAL, DATA GENERAL, PRIME. 
Algumas cidades foram assumindo suas espacializações, como é o caso de Burlington e Walthan, com a indústria HT; Bedford, com os laboratórios do MIT e a base Aérea; Lexington, detentora maior de laboratórios de pesquisa. $\mathrm{O}$ espaço fora se padronizando com essa divisão de trabalho, de tal modo que Burlington, Woburn e Billerica, em seu zoneamento livre, dispõem, de grande massa de operários, cujas propriedades são de baixo valor, ao contrário de Walthon, Lexington, Newton e Wellesley, Concord e Lincoln, por sua vez, matêm-se como loci residenciais de cientistas e engenheiros que cruzam a Rodovia 128, utilizando-se da Rota 2 em direção a Harvard, Cambridge, Boston e ao MIT.

Como Silicon Valley, Saxenian (1985) aponta no "semicírculo dourado" problemas idênticos: segregação residencial, congestionamento das rodovias, inflação do preço das moradias, escassez de trabalho, meio-ambiente saturado etc.

\subsection{A territorialização dos tecnopolos na Europa}

\section{a) Crise recessiva}

À medida que na Europa entravam em declínio as indústrias que comandavam o crescimento econômico dos "trinta gloriosos" (siderúrgicas, têxteis, automobilísticas etc.) e se elevava a importação de produtos "made in USA" e "made in Japan", com elevada adoção de inovações, além de se confrontarem com os avançados programas estratégicos dos EUA, as autoridades e o empresariado europeus alertaram-se para a falta de atenção à competitividade de seu sistema produtivo.

Conjugados com aguçamento da concorrência dos novos países industrializados que hospedem as indústrias intensivas em mão-de-obra, onde os custos de produção eram baixos, esses fatos marginalizavam do mercado internacional os produtos europeus, como se pode ver no gráfico 03 (Petrela, 1984, p. 10):

\section{Gráfico 03 -}

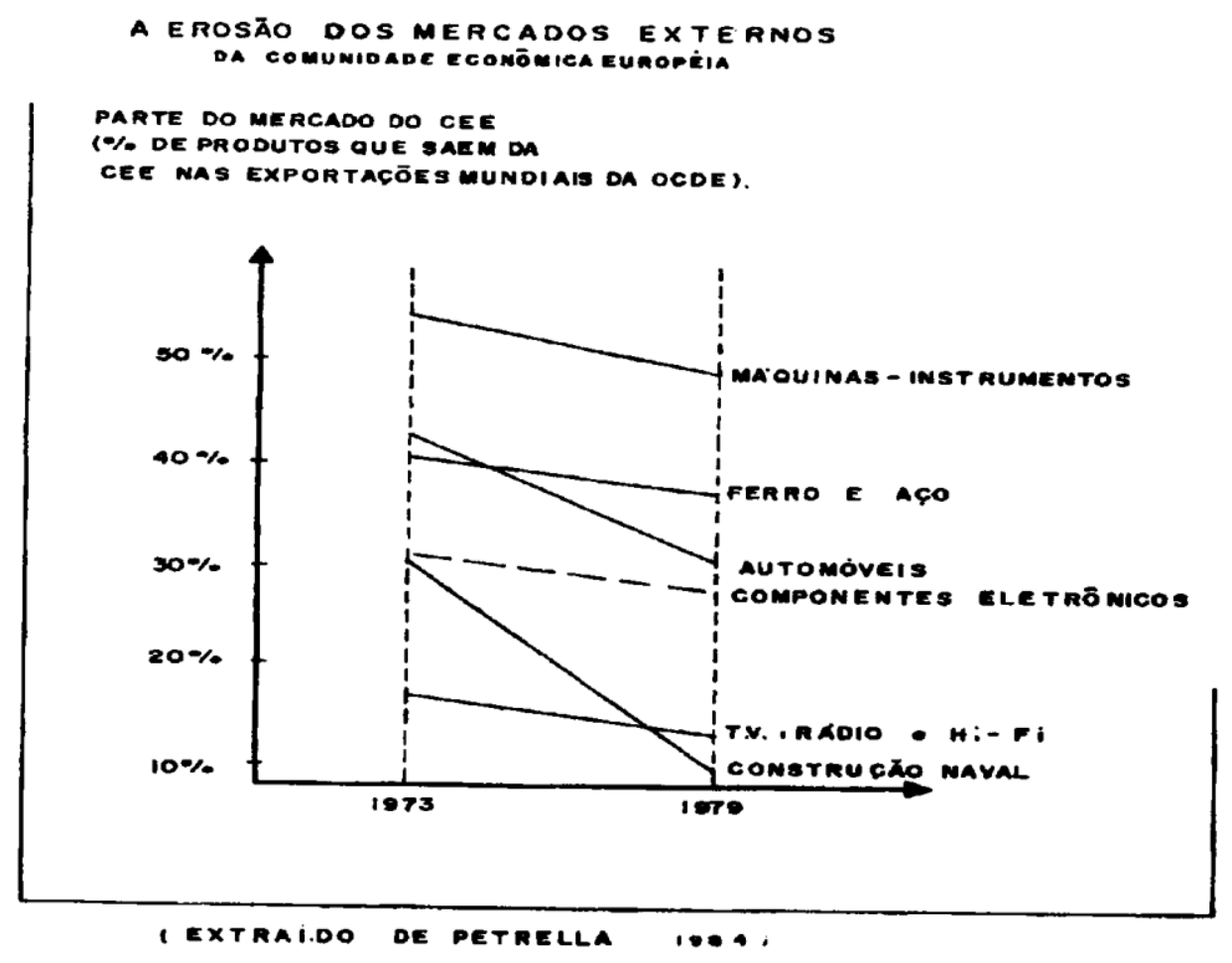


Em consequência, vários centros e regiões industriais, entre os anos 70 e início da década de 80, entraram numa profunda recessão: “Turim é profundamente marcada pela desindustrialização... e o declínio do emprego industrial é comum a todos os escalões geográficos: nacional, regional e urbano". (Jalabert e Gregoris, 1987); "em Newcastle (GB), o emprego industrial caiu, entre 1976-1981, 47\% no setor têxtil e 32\% no metal-mecânico; Besançon (Fr.) teve uma queda de $57 \%$ dos empregados na atividade relojoeira em 10 anos (1957-1985); no início dos anos 80, St. Etienne (Fr.) declinava 6\% ao ano de sua força-detrabalho; a indústria carbonífera de Chaleroi (Bélgica) de 1974 a 1983, dispensa 75,0\% de seus trabalhadores; a Suíça de 15 anos (1970-1985) fechava 60\% de suas indústrias de relógio, com uma redução de $65 \%$ dos empregados". (Aydalot e Keele, 1988).

\section{b) Esforço e reestruturação do sistema produtivo}

Com a finalidade de retomar o desenvolvimento econômico e de realinhar-se às condições exigidas pelo mercado mundial, porquanto "a competição por desenvolvimento econômico entre as nações, Estados e inúmeras comunidades é mais intensa do que entre as empresas (Ryans e Shanklin, 1988), os países europeus passaram a adotar políticas de C e T. Nortearam-se por uma série de estudos que apontava um inflexão dos investimentos de P x D para a gestão de estrutura de pesquisa, com ênfase nas universidades, voltada ao setor produtivo (Salomon, 1989), dentro da noção de transferência tecnológica. Isso se impunha, mais ainda, ante à obsolescência do capital fixo, pois "a luta da concorrência força que se substituam por novos os antigos meios de trabalho, antes de chegarem ao fim de sua vida. São sobretudo catástrofes, crises que obrigam as empresas renovar antecipadamente maquinaria e instalações em grande escala social" (Marx, 1970:178). Assim agindo, as empresas e os governos europeus procuravam se inteirar dos contornos da nova "fada tecnológica"que se esculpira nos EUA, como não desejando desalinhar-se do verso do grande poeta condoreiro: "Europa - é sempre Europa, a gloriosa!...".

Após discorrer sobre o papel estratégico da ciência e da tecnologia, o então responsável pelo Programa FAST (Planejamento e Avaliação no Campo da Ciência e Tecnologia da Comissão das Comunidades Européias), Ricardo Petrela (1984), procura responder à questão por ele mesmo proposta: "as novas tecnologias são a fonte principal de uma nova fase de desenvolvimento para a Europa?"

Já foi posto que o grande problema é a saída da crise, ou seja, a re-industrialização, conquista de mercado e criação de empregos.

Duas correntes de estudiosos se opõem. Os que se colocam contrários às inovações como geradores de emprego, o fazem pela evidência de que o sistema produtivo mais absorve inovações em processos, com modernizações e racionalização, o que funciona como redutor de emprego, ao contrário das inovações de produtos que implicam em investimento de capital e absorção de força-de-trabalho.

Contudo, a questão é complexa e deve ser examinada com cautela, tendo-se que ressaltar quatro fatores:

1) os domínios atingidos pelas inovações (bens de equipamentos, bens de consumo e bens intermediários);

2) natureza das atividades (alimentação, moradia, transporte etc.);

3) modo de regulação do mercado, e 
4) atitude dos produtores de inovações (PMEs ou grande empresa, tempo de prestação de inovação no mercado).

O Autor considera, no entanto, que a inovação é fonte de crescimento, desde que haja equilíbrio entre inovação de processo e inovação de produto, o consumo público acompanhe o consumo privado e nas trocas internacionais se mantenham regras estáveis com mecanismos apropriados aos interesses do conjunto dos países.

No caso europeu, os países concorrem entre si, com atitudes protecionistas, alianças com as corporações americano-japonesas e assimilação de inovações de processo, o que tem enfraquecido a autonomia da base industrial e tecnológica dentro do Continente.

Além de diretrizes de alguns programas - ESPRIT, FAST - Petrella sugere a certos setores da indústria européia eliminar a subcontratação a grupos americanos e japoneses e os enclaves protecionistas. Ao invés de atitudes individualistas, um programa coerente conjunto deve ser implementado por todos os participantes da C.E.E., como "a chave principal do redesdobramento da Europa". Noutra linha de ação, Salomon (1989: 51) sugere que "é no terreno da educação, da reciclagem das competências e da formação que se joga mais seriamente a batalha da competitividade. (...) Em numerosos casos, na Europa em particular, [ os sistemas de educação e de formação] não se capacitaram para atender as exigências novas de cultura e de formação técnicas que resultam do "novo paradigma técnico-econômico". Nova cultura avança com as tecnologias nascentes que se tornam mais diferentes das anteriores por serem combinatórias e contagiantes (Petrella, 1984). Com elas setores tradicionais de bens intermediários e bens de consumo são regenerados com aplicação de pesados investimentos e ajuda através de políticas públicas. No intuito de reverter o quadro, numerosas são as iniciativas regionais e locais, com ou sem ajuda do governo central a partir dos recursos científicos existentes, para reforçar as ligações universidade- empresas.

Claude Pottier (in Aydalot e Keeble, 1998), numa visão mais abrangente, crê que "hoje a reconstrução do sistema produtivo, ao nível local ou nacional, está envolvido pela rede de laços entre pesquisa e produção, treinamento técnico e administrativo e circuitos financeiros e inovação" (p. 102). Numa perspectiva mais pontual e pragmática, este Autor revela que uma das características da "reestruturação do sistema produtivo local em algumas regiões da Europa é o desenvolvimento de uma multiplicidade de mecanismos institucionais que agem como intermediários entre pequenas firmas e centros de pesquisa e de assistência técnica locais" (p. 104).

Em Louvain, criou-se, em 1986, o centro inter-universitário de micro-eletrônica junto às equipes de Grand e Bruxelas, em França, espalham-se os CRITT (Centros de Inovações e de transferência de Tecnologia), a partir de Greenoble e Tolouse; muitos são os tecnopolos em vários países da OCDE.

Como integração técnico-científica entre países, Alemanha e Suíça desenvolvem programas comuns e no pólo Midi-Pirenées se associam França e Espanha (Catalunha), com apoio da C.E.E. (Salomon, 1989); o Parque Industrial de Pesquisa do Sart Tilman, em Liège (Bélgica), trabalha em colaboração com o PROMOTECH que atua no tecnopolo de NancyBrabois (França) na transferência de tecnologia (Bruhat, 1990), com BTC Twent, na Holanda ( Sunmam, 1986). Na Conferência sobre tecnopolos, realizado em 1985, em Berlim, propunha-se a formação de redes de parques científicos, a cooperação entre universidades e empresas como um dos papéis dos tecnopolos europeus, "como um elemento vital de uma política regional frutífera" (Gibb, 1985; E.E.C., 1985). 


\section{C) Parques científicos, instrumentos de renovação}

\section{I - Terminologia européia}

Entre as medidas de renovação e desenvolvimento regional da Europa estão os science parks ou tecnopolos. Em diferentes países, essas iniciativas têm procurado associar as instituições de alto nível de ensino e pesquisa às empresas (indústrias e serviços) com o objetivo de transferir a estas os resultados de suas investigações.

Nuanças várias - dimensão da área ocupada, amplitude de meios para a produção e serviços, complexidade de tipos de indústria - fazem variar a nomenclatura das iniciativas em vários países europeus: centro de inovação, science parks, parques de pesquisa, parques tecnológicos, denominações que se conjugam no mesmo fenômeno.

Além desses, os franceses utilizam o termo tecnopolo, no gênero masculino, para designar áreas delimitadas, semelhantes a distritos industriais de alta tecnologia; quando expressa sentido de espaço urbano dominado pelas atividades de alta tecnologia em comércio, serviço, instituições de ensino e pesquisa e indústria, o termo tecnopolo é posto no gênero feminino, como dizer-se a cidade tecnopolo ou tecnópole (Tesse, 1985).

\section{II - O movimento no Continente}

Desde o final dos anos 60, surgem na Europa - França, Bélgica, Grã-Bretanha, entre outros - modelos variados de tecnopolos, tentando reproduzir o fenômeno que surgira, sem planejamento governamental, na Califórnia, no pós-guerra imediato.

A feição de prefácio em um de seus livros sobre o assunto, Hilary Sunman (Sunman e Lowe, 1986) elaborou um sumário, sob o título The European Experience, tratando dos tecnopolos no Continente, onde o movimento se estabeleceu com maior vigor no período dos anos 80. Por seu tratamento coerente à questão, tomamos esse texto como referência básica nessa parte da abordagem.

Em 1980, eram apenas 10 os tecnopolos com 400 estabelecimentos, chegando em 1986 a 79 tecnopolos com 1.000 empresas, tendo-se registrado um crescimento mais expressivo na Alemanha, que só iniciara em 1983.

Com objetivos semelhantes, as ações variaram entre países e entre regiões, modeladas por suas indiossincrasias.

Na Alemanha, prodeminam empresas de pequeno porte nos centros de inovação que ocupam áreas de menos de 1 há; a França, ao contrário, elegeu os tecnopolos, muitos dos quais envolvendo cidade ou grande parte dela com pesadas instituições de ensino e pesquisa públicas ou ligadas a grandes empresas; Bélgica e Holanda esforçaram-se por atrair empresas sem muita relação com a universidade, mas também desenvolveram centros com PMEs de alta tecnologia spin-offs de universidades especializadas, na Grã-Bretanha desenvolveram-se diferentes tipos de science parks em sua maioria em áreas diminutas, cujo número passou de 30 em apenas meia década.

No geral, os tecnopolos europeus derivam de política governamental com subsídios e incentivos. 
Algumas empresas, recebem suportes diretos e indiretos do governo, o que as impedem de fortalecer seu poder concorrencial, tornando-as vulneráveis; muitas outras, no entanto, conseguem recursos dos bancos que são estimulados pelo poder públicos.

Os fundos públicos, por outro lado dispendem $75 \%$ dos investimentos em infra-estrutura dos parques.

\section{III - Fórmulas para desenvolver os tecnopolos na Europa}

Quer servindo como "remédio para zonas sinistradas", quer como "centros preocupados em construir seu futuro sobre as novas tecnologias"(Certaies, 1988), Sunman distingue duas fórmulas para desenvolvimentos dos tecnopolos na Europa:

1) Baseado na transferência de tecnologia, com uma clara e forte participação da Universidade em sua estrutura e organização, com natural tendência a melhor aproveitar os recursos locais. Nesse caso, os investimentos externos dirigir-se-ão para as pesquisas da Universidade, de onde podem surgir "spin-offs" em forma de PMEs com efeitos multiplicadores para a economia local e regional.

2) derivado do planejamento regional e estabelecido por iniciativa do governo local. Esse tipo de tecnopolo tende a atrair empresas com pouca relação com instituições acadêmicas, porquanto suas iniciativas de $\mathrm{P}$ x D são importadas de centros externos à região ou ao País. Outras empresas são subcontratadas de corporações, nem sempre se voltando para o desenvolvimento regional.

Provavelmente em face desse último tipo de modelo de tecnopolo, tem-se formado uma corrente de opinião crítica à proliferação dos tecnopolos. Evidencia-se uma diluição dos efeitos com a desvalorização dos investimentos, em grande parte, como vimos, originados do poder público.

\section{IV $-1^{\circ}$ fase dos tecnopolos europeus}

Numa relação de 117 tecnopolos em dez países europeus da OCDE(Tabela 07) verificamos que somente uma dezena surgira antes de 1980, o que confirma Hilary Sunman em seu texto The European Experience: 3 em França, (Sophia-Antipolis, Nancy- Brabois e ZIRST de Meylan-Grenoble), 4 na Bélgica (Louvain-la-Neuve, Evère, Liège, Leuven), 2 na Grã-Bretanha (Cambridge e Heriot-Watt em Edimburgo) e 1 na Suécia (Kista, cidade nova, ao norte de Estocolmo).

Evidencia-se, com esses dados, que a emergência de tecnopolos na Europa tem duas fases: uma anterior ao aguçamento da crise recessiva dos anos 80 e outra marcada por fatores vários, como vimos, destacando-se os esforços de reconversão de áreas em decadência.

Os tecnopolos mais recentes decorrem, em sua maioria, do planejamento governamental, no intuito de aproveitar recursos potenciais já existentes (assentá-los ou atrá-los), com o objetivo de sair da crise e remontar o sistema produtivo na métrica do paradigma tecnoeconômico vigente no mundo desenvolvido.

Antes dos anos 80 o alvo se centrava, principalmente, num processo de acompanhar a cadência das duas conhecidas regiões HT norte-americanas - Vale do Silício e Rodovia 128cuja marca mais expressiva as enquadra no primeiro tipo de desenvolvimento exposto. 
Tabela 07

Ano de Criação do Tecnopolos

DEZ PAÍSES EUROPEUS DA OCDE

\begin{tabular}{c|r|r|r|r|r|r|r|r|r|r|r}
\hline $\begin{array}{c}\text { País } \\
\text { Criação }\end{array}$ & $\begin{array}{c}\text { Alema- } \\
\text { nha } \\
\text { (1) }\end{array}$ & $\begin{array}{c}\text { Bélgi- } \\
\text { Ca (2) }\end{array}$ & $\begin{array}{c}\text { Espa- } \\
\text { nha (3) }\end{array}$ & $\begin{array}{c}\text { Finlâ- } \\
\text { dia (4) }\end{array}$ & $\begin{array}{c}\text { Fran- } \\
\text { ça (5) }\end{array}$ & $\begin{array}{c}\text { Grã- } \\
\text { Breta- } \\
\text { nha (6) }\end{array}$ & $\begin{array}{c}\text { Holan- } \\
\text { da (2) }\end{array}$ & $\begin{array}{c}\text { Irlan- } \\
\text { da (2) }\end{array}$ & $\begin{array}{c}\text { Itália } \\
\text { (4) }\end{array}$ & $\begin{array}{c}\text { Suécia } \\
\text { (4) }\end{array}$ & Total \\
\hline $\begin{array}{c}\text { Antes } \\
\text { de } 1980\end{array}$ & & 4 & & & 3 & 2 & & & & 1 & 10 \\
\hline $\begin{array}{c}\text { De } 1980 \text { a } \\
1984\end{array}$ & 6 & & 3 & 1 & 6 & 14 & 2 & 1 & 3 & 3 & 39 \\
\hline $\begin{array}{c}\text { A partir } \\
\text { de 1985 }\end{array}$ & 26 & 2 & & 5 & 11 & 22 & 1 & & & 1 & 68 \\
\hline Total & 32 & 6 & 3 & 6 & 20 & 38 & 3 & 1 & 3 & 5 & 117 \\
\hline
\end{tabular}

Fontes: 1. Sunman e Lowe, 1986; 2. Sunman, 1986; 3. Couvidat Giustl, 1991; 4. Jalabert e Gregoris, 1987 e Couvidat e Giusti, 1991; 5. Bruhat, 1990 e 6. UKSPA, 1989.

Obs.: Os dados não indicam a totalidade de tecnopolos de cada país.

Os tecnopolos pioneiros no espaço europeu refletem uma séries de características dos dois exemplos clássicos americanos: proximidade física aos centros de pesquisa; formação de parques industriais HT junto ao campus universitário; projeção espacial das atividades de pesquisa, da produção e da habitação dos técnicos, dirigentes e pesquisadores, em boas condições físico-ambientais e de tranquilidade social, o que se convencionou chamar de meio ambiente agradável para trabalhar e viver; desenvolvimento tecnológico decorrente de pesquisa acadêmica diretamente voltada aos interesses empresariais e aos mercados.

"Fortemente inspirado no modelo americano dos campi, como F. Terman os tinha pensado e organizado" (Couvidat e Giust, 1991), foi criado o Campus de Ricarton pela Universidade de Heriot-Watt, em Edimburgo, GB, numa área fora dos marcos da cidade; assim se fez, também, na Universidade de Cambridge, cuja ampliação das áreas se deu sob forte pressão especulativa sobre as terras; para a montagem do Pólo Tecnológico regional de Nancy-Brabois, em França, foram reservados 500 ha. próximos ao Campus, no sentido de incentivar a transferência de tecnologia na íntima convivência universidade e indústria; a ZIRST Meylan - Grenoble se inspirou na vitrina da Rodovia 128, em torno de Boston , idéia nascida em 1969 no seio da Universidade de Grenoble com o apoio do Instituto Politécnico, para construir um bom lugar para viver e trabalhar próximo à Universidade. Mais radical do que essa decisão francesa, foi a de erguer a $20 \mathrm{~km}$, de Estocolmo, a cidade de Kista, onde se assentariam condições para brotar um novo Vale do Silício, contando com recursos do governo e das grandes companhias suecas. As universidades belgas também estavam abertas para o que se projetava em solos europeus entre os anos 60 e 70, modeladas pela corrente de idéias e experiências provindas do outro lado do Atlântico: com o objetivo de criar emprego através do desenvolvimento da indústria HT, na Universidade de Leuven em 1972, a $30 \mathrm{~km}$ de Bruxelas, criou-se um parque de 120 ha. próximo 
à Universidade a ao aeroporto, caminho semelhante seguiria, anos depois, a Universidade Livre de Bruxelas, reservando 25 ha. para desenvolver seu espaço industrial, onde hoje domina a micro-eletrônica; com a depressão do carvão, na busca de "colher benefícios da pesquisa acadêmica"e de construir laboratórios especializados de companhias privadas, à Universidade de Liège colheu de bom grado a idéia e o apoio de Comitê Ministerial de Coordenação Econômica e Social (CMCES) para montar um parque de 27 ha. em SartTilman, um pouco afastado da Cidade (Sunman, 1986). O projeto belga mais ambicioso desenvolveu-se na Universidade Católica de Louvain: ante às divergências sobre o assunto, em novembro de 1968, criou-se, num lugar tranquilo a $30 \mathrm{~km}$. de Bruxelas, o Campus da Universidade de Louvain-la-Neuve, numa área de 140 ha. para desenvolver a região, seguindo o modelo de Leuven (atrair indústrias) e de Boston (promover transferência de tecnologia).

Estavam semeados os grãos que nas décadas seguintes propiciariam efeitos demonstrativos que se enraízam por todas as regiões do Velho Continente, na tentativa de rejuvenescerem as áreas tradicionais, reedificarem os escombros dos lugares abandonados, construírem um semblante de modernidade para o futuro.

\section{$V-2^{\circ}$ fase dos tecnopolos europeus}

A expansão territorial dos tecnopolos europeus, nos anos 80 , se dá ligado à crise que desmontava a organização fordista com a derrocada dos centros manufatureiros onde se assentavam as grandes produções tradicionais. Justapõem-se, a esses centros, grandes aglomerados humanos, alimentadores de uma rede urbana que dispunha de bons equipamentos, infra-estruturas locais e regionais, serviços e uma forte cadeia de agências financeiras e órgãos governamentais. Essa base não se dissiparia com os vendavais da crise. Pelo contrário, seria a parte instrumental do processo de renovação, cujos atores surgiram dos mais diferentes setores políticos, econômicos e culturais.

$\mathrm{Na}$ segunda onda de tecnopolos, agregam-se as ações do planejamento governamental descentralização, política de desenvolvimento regional etc. - conjugados com a vontade política local e regional de redefinir os rumos do crescimento econômico, aproveitando os recursos existentes - humanos, escolas, capital, infra-estrutura - tornando-os capazes de gerar vantagens competitivas, como fora demonstrado com os pioneiros da década anterior, na Bélgica, Suécia, França e Grão-Bretanha.

Essa vontade política se destaca na França, com a viagem do Presidente François Mitterrand e comitiva de empresários e cientistas ao Vale do Silício, em início de abril de 1984 (Anderson, 1984)

Verifica-se que a alocação das potencialidades técnico-científicas e produtivas um pouco distanciada das grandes aglomerações resultaria num grau de sinergias rapidamente absorvidas pelo lugar, o que o tornaria um relais na formação de redes com centros semelhantes e com mercados consumidores, mesmo na escala mundial. Não só se fortalecendo como ponto de atração de corporações, esses lugares assumem, primordialmente num continente em crise e desarranjos das grandes empresas, o papel de canteiro de PMEs de alta tecnologia com as transferência de tecnologias geradas nos laboratórios e institutos de pesquisa. 


\section{D - Os países líderes}

Nesse cenário do Continente, França, Grã-Bretanha e Alemanha tomaram a dianteira na instalação de tecnopolos, tanto pela pujança de cada um, quanto pela capacidade econômicoprodutiva entre os países europeus. Países outros de porte técnico-econômico, cultural ou territorialmente mais limitado - Finlândia, Suécia, Bélgica, Holanda, Itália, Espanha etc - se apresentam hoje com certo desempenho na organização de seu suporte técnico-produtivo dirigido aos objetos tecnopolitanos.

\section{I - Alemanha}

Considerada a Alemanha dos anos 80, em seus 8 (oito) Estados e três Cidades-Estados (Berlim-ocidental, Hamburgo e Bremen) há correspondência entre o adensamento dos tecnopolos com o de instituições de ensino e pesquisa e com a densidade demográfica, conforme nos mostram os mapas 05, 06 e 07.

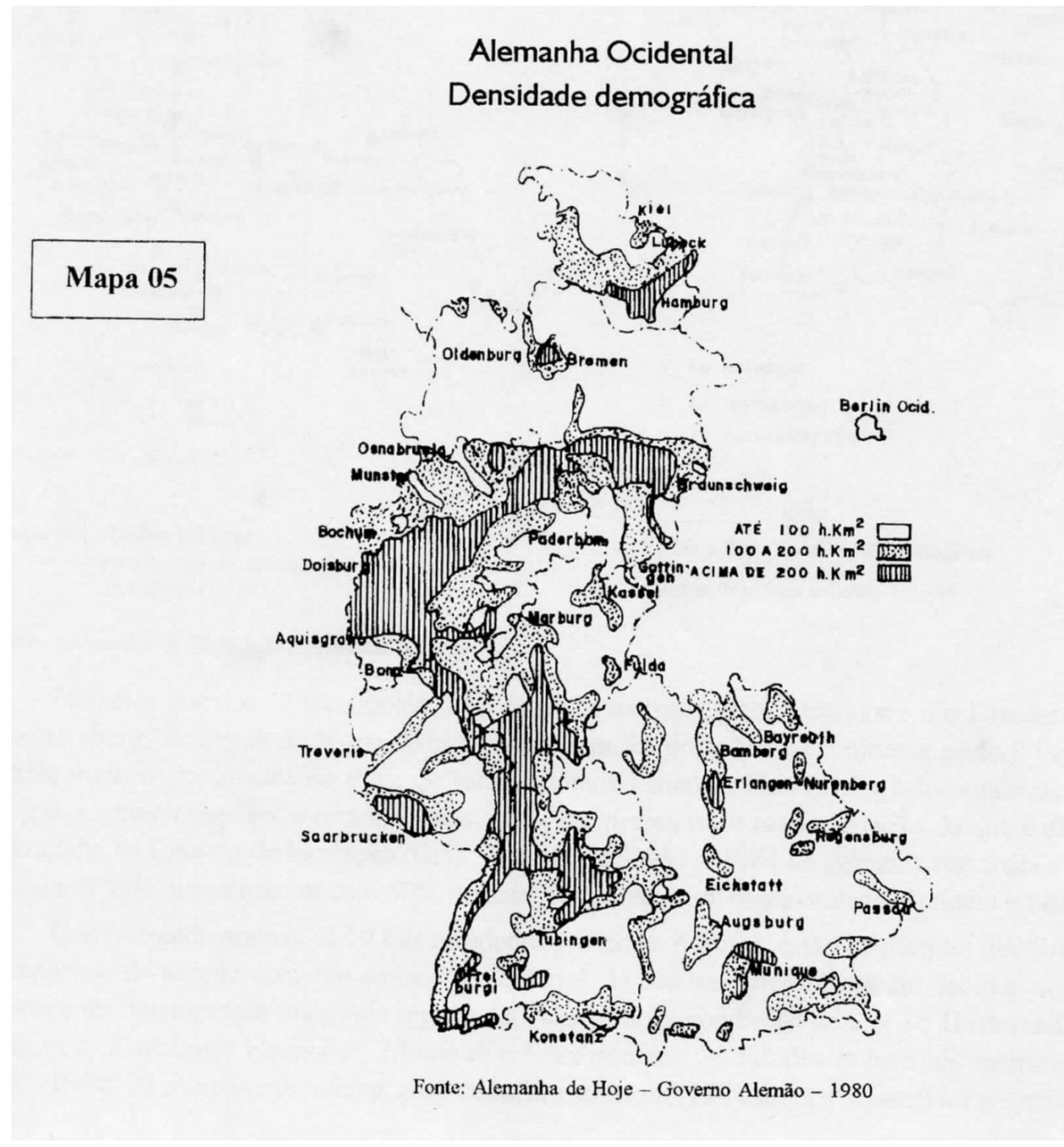




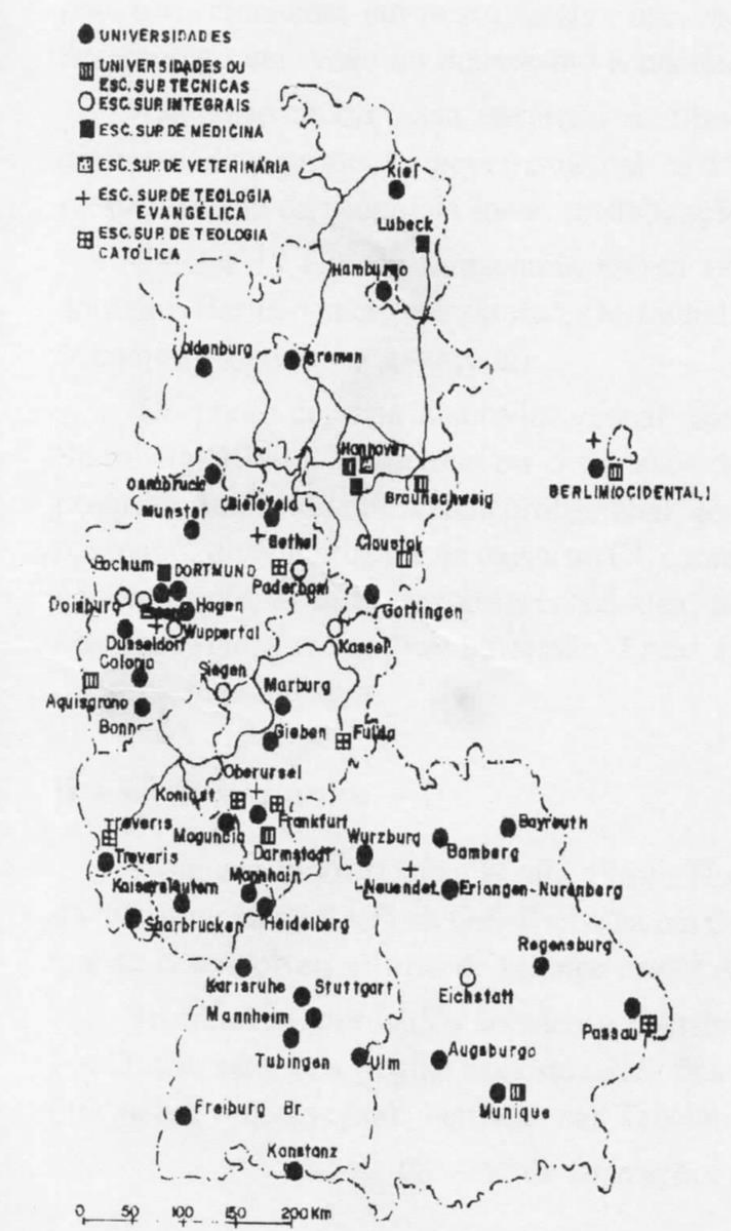

Mapa 06 (excluindo as escolas superiores Pedagogia)

Fonte: Alemanha de Hoje - Gov. Alemão - 1980

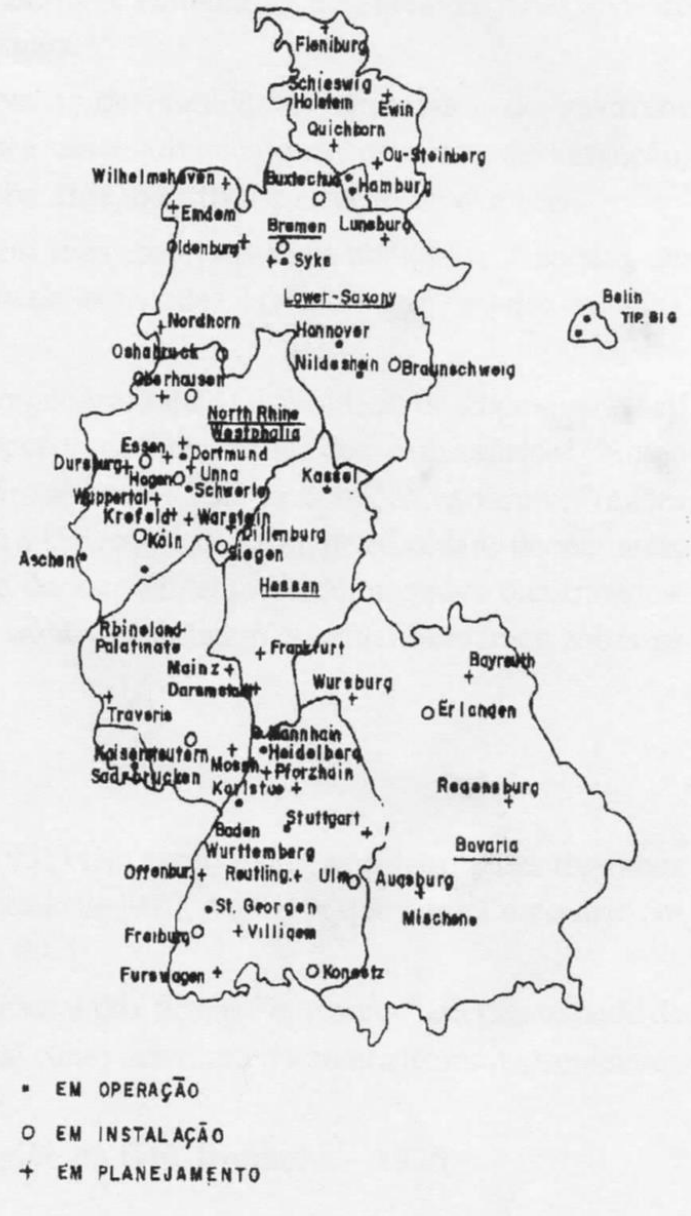

Fonte: Sunman e Lowe -1986

Notemos que dos 32 tecnopolos, 84,4\% estão nas três Cidades-Estados e nos Estados de Baden-Wurttemberg, Renânia do Norte, Westfália e Baixa Saxônia. Nestes 3 últimos estão 8 (oito) das 11 (onze) maiores indústrias do País, do setor automobilístico ao eletrônico e telecomunicações, o que dá aos governos regional estadual capacidade de investimento para a criação do que é chamado na Alemanha de Centros de Inovação (CIs), visto que de 1981 a 1985 as agências regionais e estaduais, como um todo, participam com 50\% do total dos gastos com esses centros (Sunman e Lowe, 1986).

Considerando apenas os 19 CIs estudados por esses Autores, estão os parques distribuídos em 5 categorias, de acordo com seu ambiente industrial: 1) centros siderúrgicos em declínio com elevado número de desemprego, malgrado alguns detivessem boas condições de $\mathrm{P}$ x D: Dortmund, Schwert, Aaschen, Karlshule, Hannover, Munique e Saarbrucken; 2) cidades industriais menores: Bonn e Heidelberg; 3) centros com menor grau de infra-estrutura: (Hildeshein e Kassel) ou pequenas cidades 
agrícolas afastadas de pólos universitários e industriais (St. Georgen e Syke); 4) destacadas metrópoles com boas condições infra-estruturais e universidades: Berlim e Hamburgo, e 5) área de baixo nível de desemprego em razão do dinamismo econômico: Sttutgart.

De certo modo, essa variação de tipos se deve às desigualdades regionais e de objetos diferenciados: produção governamental às PMEs para desenvolvimento do processo de inovação, reestruturação da economia local, revitalização da velha área industrial e criação de emprego.

Desses 19 CIs em funcionamento em 1986, 4 têm suas empresas mais dedicadas a apenas um domínio: Berlim (micro-eletrônica), Dortmund (engenharia avaçada), Heidelberg (pesquisa médica), Munique (engenharia avançada)

Do ponto de vista macro-locacional, conforme o geógrafo da Universidade de Hannover, Rolf Sternberg (1989), "o sucesso ou o fracasso do CI depende do julgamento dos empresários". Numa pesquisa realizada por aquele profissional, com 177 firmas em $31 \mathrm{CIs}$, as opiniões variam: "razões pessoais", disponibilidade de vagas no CI, contatos com a Universidade local, proximidade do mercado, conhecimento da infra-estrutura econômica, facilidade de recrutamento de empregados qualificados, boas atividades recreativas na região. Esses aspectos atrativos se ligam ao que abordamos sobre os distritos marshalianos.

\section{II - Grã-Bretanha}

Alguns estudos (Oakey et ali, 1980 e Howells, 1983) têm evidenciado as disparidades regionais da distribuição de P x D na Grã-Bretanha em fins da década de 1970, realidade que nos dá o cenário em que se desenvolvem o surto de science parks dos anos 80 .

Examinada, por vários ângulos, a distribuição espacial das firmas "inovantes" e a capacidade de P x D, tem sempre a Região Sudeste (onde fica Londres) como detentora do ambiente mais propício às inovações: o que se pode verificar nas Tabelas 08 e 09.

Tabela 08 - N de Inovações por Região da Grã-Bretanha - 1975

\begin{tabular}{l|c}
\hline \multicolumn{1}{c|}{ Região } & $\begin{array}{c}\text { Inovações por } \\
\text { Região }\end{array}$ \\
\hline 1. East Anglia & 12 \\
2. South-West & 22 \\
3. South-East & 98 \\
4. North & 21 \\
5. East Midlands & 19 \\
6. Yorkshire and Humberside & 24 \\
7. West Midlands & 33 \\
8. North-West & 33 \\
9. Scotland & 19 \\
10. Wales & 6 \\
\hline Great Britain & 287 \\
\hline
\end{tabular}

Fonte: Oakley et ali - 1980 
Tabela 09 - Participação Regional de Serviços de P x D na Grã-Bretanha

\begin{tabular}{l|r|r|r|c}
\hline \multicolumn{1}{c|}{ Região } & \multicolumn{2}{|c|}{1971} & \multicolumn{2}{c}{$\mathbf{1 . 9 7 6}$} \\
\hline Central & Empregados & \% (País) & Empregados & \% (País) \\
\hline South East & 46.607 & 52,2 & 62.337 & 57,4 \\
\hline South West & 9.336 & 10,4 & 6.588 & 6,1 \\
\hline East Anglia & 4.480 & 5 & 4.779 & 4,4 \\
\hline Intermediate & & & & \\
\hline North West & 8.283 & 9,3 & 10.361 & 9,5 \\
\hline Yorkshire/Humberside & 2.327 & 2,6 & 3.553 & 3,3 \\
\hline West Midlands & 3.934 & 5,5 & 5.125 & 4,7 \\
\hline East Midlands & 2.876 & 3,2 & 4.118 & 3,8 \\
\hline Peripheral & & & & \\
\hline Northem & 2.049 & 2,3 & 2.769 & 2,5 \\
\hline Wales & 1.102 & 1,2 & 956 & 0,9 \\
\hline Scotland & 7.322 & 8,2 & 108.681 & 100 \\
\hline Great Britain & 89.136 & 100 & & 7,4 \\
\hline
\end{tabular}

Fonte: Howelles - 1983

Mais de 1/3 das inovações consideradas na Grã-Bretanha, em 1975, tinha sua aplicação em empresas do sudeste, o triplo de inovações detidas pelas regiões que se colocam em $2^{\circ}$ lugar (West Midlands e North West). Nesse conjunto, tênue era a expressão do de Gales (Wales) e East Anglia.

A estatística da evolução dos serviços de P x D, entre 1971-1976 ratifica mais ainda o Sudeste da Inglaterra no comando dos meios de pesquisa. Isso está bem claro nesse excerto de Goddard e Smith citados por Oakley et ali; "A posse de uma estrutura vantajosa de empregados não-produtivos no sudeste que pode produzir um alto nível de inovação pode ser o resultado da crescente concentração de controle da indústria britânica nessa região nos anos recentes. Em consequência, as funções de alto comando associadas com decisões de fazer a atividade inventiva têm sido centralizada em torno de Londres" (p. 247).

Melhor posicionadas aparecem North-West e as Escócia, mas o País de Gales se mantém numa baixa referência. A propósito dessa porção da Grã-Bretanha, convém referirmo-nos ao papel desempenhado pelo Corredor M-4, a via expressa que à interliga a Londres (Mapa 08).

Em face da presença de grandes centros de pesquisa em energia (Aldermaston e Harwell), em aeroespacial (Bristol e Farnborough) e transporte (Bracknell) em torno dessa via, empresas estrangeiras aí se instalaram, acompanhadas por sedes administrativas, PMEs e serviços que a afastavam da grande metrópole em busca das town news, onde as condições de vida eram melhores. Esses fatos contribuíram para os benfazejos ventos das novas tecnologias arejarem a vida dos celtas. Groeso i gymru (bem-vindos a Gales) diriam em sua língua materna. 


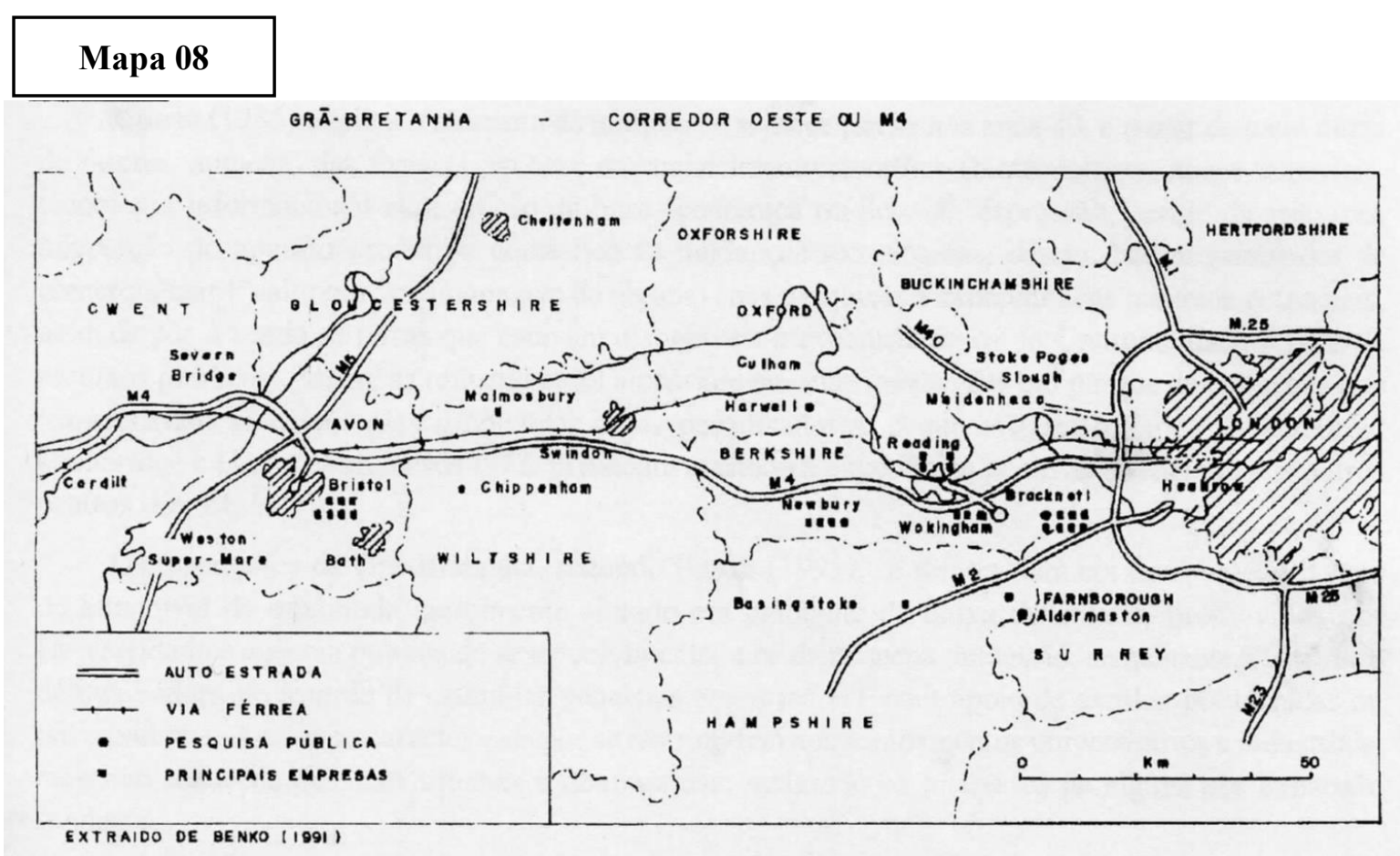

Essa descentralização de empresas e instituições de pesquisa e assentamento de uma mãode-obra altamente qualificada no eixo do Corredor Oeste (M-4) deram margem a que o País de Gales avançasse no movimento tecnopolitano.

Por outro lado, a Escócia teve seu impulso modernizante com as centenas de firmas estrangeiras que formaram, nos primeiros anos da década de 80 , a terceira maior concentração mundial do domínio da eletrônica no chamado Silicon Glen, uma faixa de 150 por $50 \mathrm{~km}$, que se estende de Pestwick, a Sudoeste, a Dundee, a Nordeste, envolvendo inúmeras cidades como St. Andrews e Edimburgo. (mapa 09)

Não foram os mistérios dos lagos, nem a fama da nobre bebida da terra, mas as vantagens financeiras e fiscais oferecidas pelos governantes para minimizar o desemprego, a fraca sindicalização da força-de-trabalho, o acesso ao MCE e a língua comum que atraíram os fabricantes norte-americanos e, com eles, os japoneses (Chancel, 1985). "No Silicon Glen, nos diz Certaines (1988), "a Scottish Development Agency multiplicou as subvenções excepcionais e atraiu numerosas empresas, notadamente estrangeiras; mas a informática do Silicon Glen aproveitou os filhos de desempregados e não os "excluídos" do carvão, do aço e do petróleo" (p. 28). Nesse aglomerado de centros urbanos estão as mais destacadas universidades do País e, a partir delas, uma força-de-trabalho de alto nível, que seriam a base do novo modelo industrial voltado às PMEs de alta tecnologia.

Para Rodney (1985), os "parques pré-tecnopolitanos" de indústrias leves refletiam algumas insatisfações dos anos 60: movimento estudantil baby boom derivado das universidades clássicas, a insatisfação com as condições urbanas que levou à construção das town News nas periferias das metrópoles e, por consequência, a expansão das redes de transporte e comunicação. As tradicionais universidades urbanas transferiram-se para o campus, lugar de bem-estar fora das grandes cidades, como se fez com Heriot-Watt (ver artigo de Chancel, 1985). Na compreensão de Rodney, cortes nas subvenções das universidades, ante à crise do Estado, forçaram-nas a procurar recursos nos contratos com empresas e a estas responderam com projetos eficazes, daí nascendo os pólos de excelência, os parques científicos. 
Currie (1985) explica o aumento de número de science parks nos anos 80, a partir de meia dúzia de fatores: aumento das firmas com base no conhecimento científico (biotecnologia, novos materiais, tecnologia informacional etc); erosão da base econômica tradicional; depressão; perigo da vagarosa adaptação ao aparato produtivo doméstico às mudanças tecnológicas; desejo das universidades de comercializar ("valorizar" na linguagem de alguns) suas pesquisas e expandir seus recursos potenciais, além de por à venda as terras que estavam disponíveis à expansão física do Campus, dada à falta de recursos públicos. Assim, as universidades alocariam em suas imediações um parque de empresas que transfeririam as tecnologias produzidas pelos pesquisadores, o que evitaria o êxodo de cérebros; Cambridge e Heriot-Watt, desde 1972, já haviam atestado a experiência positiva vivenciada por outros centros dos EUA.

Os tecnopolos da Grã-Bretanha, segundo Benko (1991), se diferenciam em duas categorias: os de alto nível de qualidade, geralmente situado em ambiente de baixa densidade, promovidos por Universidade e agência publica de desenvolvimento; e os de pequena dimensão, semelhante à estrutura de incubadora no sentido de estimular pequenas empresas HT com apoio de escolas politécnicas ou universidades. Ambos se caracterizam por se restringirem aos equipamentos universitários e industriais, marginalizando as questões urbanas e de moradias, malgrado os interesses de alguns por expansão fundiária.

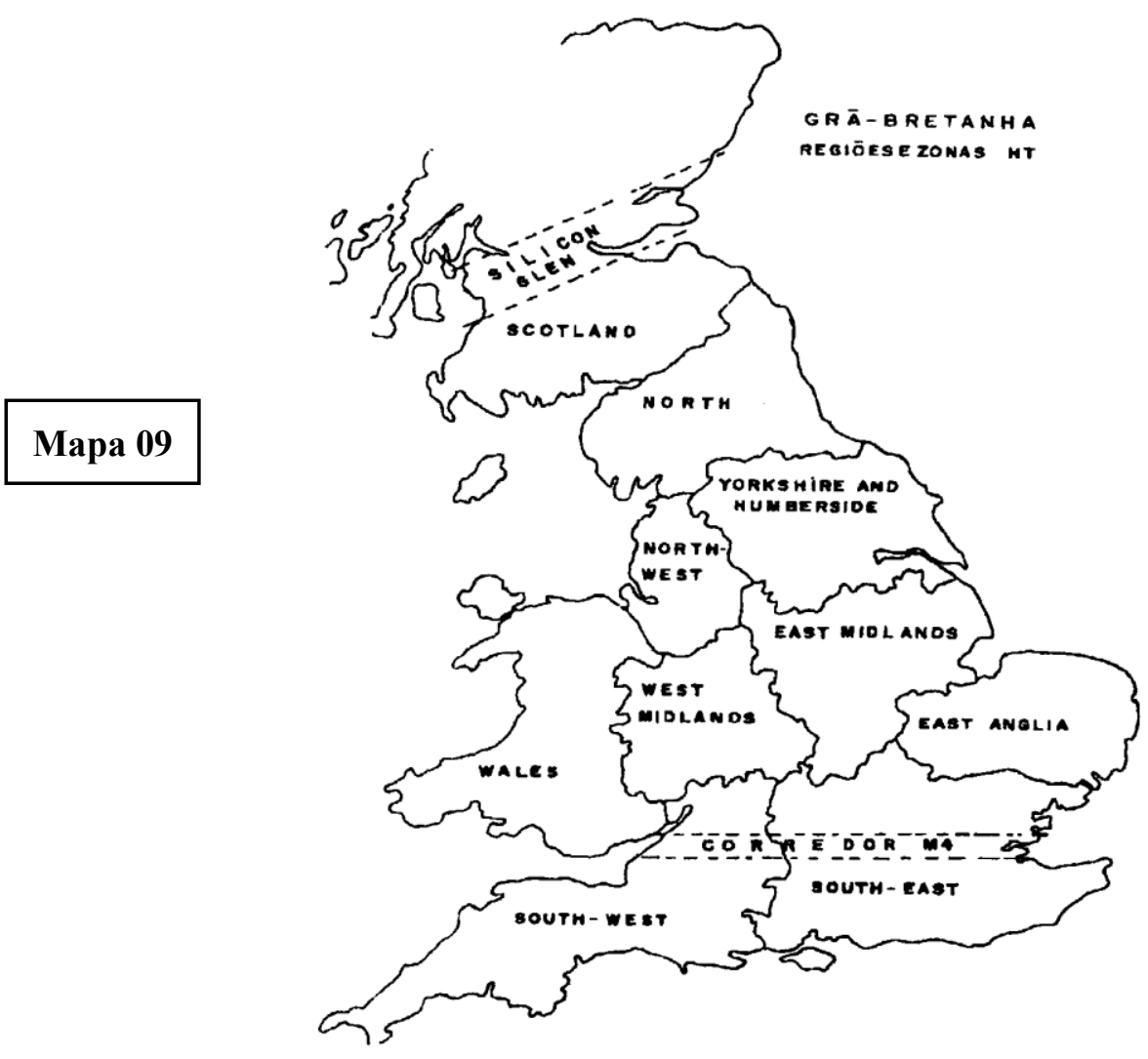

De 1972 a 1988, segundo o relatório de agosto de 1989 da UKSPA, haviam sido implantados 38 science parks nas diferentes porções territoriais da Grã-Bretanha (Tabela 10 e Mapa 09). 
Tabela 10 - Grã-Bretanha

Distribuição Regional dos Science Parks

\begin{tabular}{l|c}
\hline \multicolumn{1}{c|}{ Região } & Tecnopolos \\
\hline South-East & 6 \\
South-West & 5 \\
Wales & 4 \\
West-Midlands & 3 \\
East-Anglia & 2 \\
East-Midlands & 4 \\
North-West & 4 \\
Yorkshire e Humberside & 3 \\
North & 5 \\
Scotland & 2 \\
North-Ireland & 38 \\
\hline Total & \\
\hline
\end{tabular}

Fonte: UKSPA - 1989

Com cinco parques, pouco menos que a região onde fica Londres, a Escócia e Gales (Wales) não se isolaram do movimento, aproveitando seus valorosos recursos de inteligência e favoráveis condições de localizações, como rodovias e aeroportos.

Cerca de 76,3\% dos parques britânicos ocupam áreas de até 10 ha, mas neles estão $70 \%$ das 812 empresas. Os de área acima de 10 ha. três estão na Escócia (Edimburgo, Glasgow e Aderban), dois no South-East (Surrey e Southampton) e com apenas um as regiões de East Anglia (Cambridge), West Midlands (Warwick), Irlanda do Norte (Autrin) e Gales (Wrexhan).

Comparando com os dados regionais sobre a criação de inovações e presença de serviços de P x D, podemos concluir com Medeiros (1988): "a partir de 1982, os parques tecnológicos não necessariamente sugiriam nas regiões mais dinâmicas do ponto de vista científicotecnológico". Com exclusão do South-West, os 38 parques estão regularmente distribuídos por toda a Grã-Bretanha, o que não sintoniza com os dados estatísticos do terciário superior.

\section{III - França}

Participante preeminente das duas gerações de indústrias (siderúrgicas e têxteis da $1^{\circ}$ e $2^{\circ}$ são as indústrias automobilística, aeronáutica, química de síntese e material elétrico), a França, na nossa atualidade, desempenha um papel não menos destacado na Terceira Revolução Industrial, a revolução técnico-científica. Isto se dá não como salto, mas na constante renovação do velho com a agregação do novo, na remontagem do tradicional em busca do realinhamento, a fim de responder às necessidades e 
exigências do mundo. É na crise que se delineiam os esboços dos modelos, dos paradigmas capazes de atender o futuro.

Em seu longo percurso de sociedade industrial, a França pôde instalar o que de mais necessário se fazia para a vida social e produtiva: rede de variados tipos de eficientes vias de comunicações, bem equipados aeroportos internacionais, alto padrão de serviços amplamente distribuídos pelo País, sólida base energética, possante sistema bancário etc. Sobressai-se, internacionalmente, o aparato de instituições de ensino e pesquisa, públicas e privadas, dentre as quais respeitadas Universidades com inúmeros laboratórios em variados domínios científicos.

Esse suporte tem possibilitado ao País desenvolver, renovar e ampliar seu complexo parque industrial, como também participar e impulsionar projetos internacionais de alto padrão, apesar da fase recessiva do atual ciclo da economia mundial, crise que tem afetado muitas regiões francesas. Nesse ritmo, a França acompanha a estruturação dos parques técnico-científicos ou tecnopolos.

Aceitando as quatro dezenas de tecnopolos (Couvidat e Giusti, 1991), verificamos que somente em três regiões administrativas -Champagne-Árdenas, Auvergne e Córsega - eles não estão presentes. A maioria situa-se nas regiões voltadas ao circuito marítimo do Mediterrâneo (Provence-Alpes-Côte d'Azur com 6) e do Atlântico (Aquitânia, 4; Vale do Loire, 3; Bretanha, 3), outro conjunto é formado pelas regiões limítrofes aos países mais envolvidos com tecnopolos (Alemanha, Itália, Bélgica): Ródamo-Alpes, 4: Lorena, 2; FrancoCondato, 1. No interior do País só Borgonha e Île-de-France dispõem de 2 tecnopolos, enquanto as demais só mantêm um (Mapa 10).

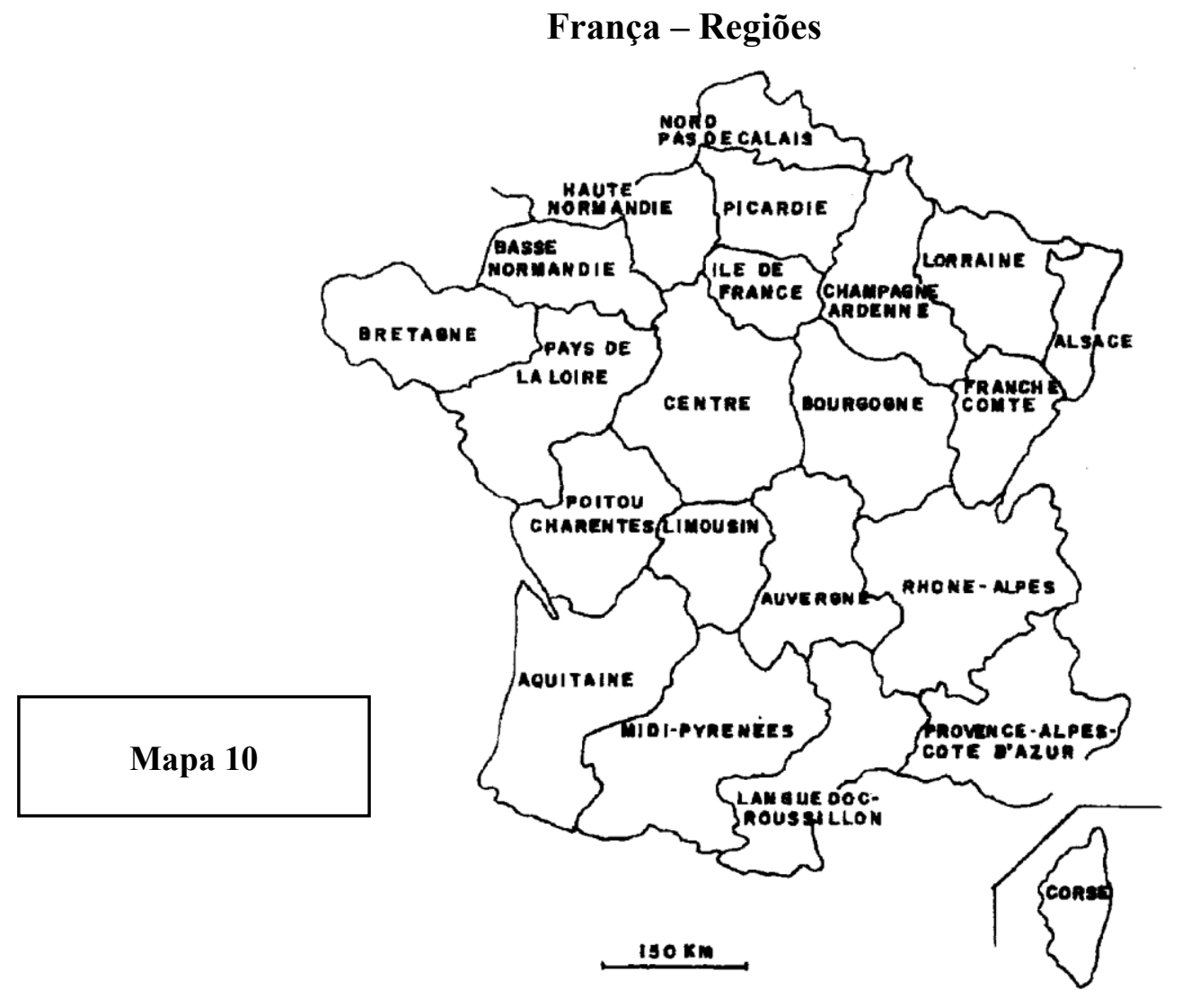


Ainda na escala regional, examinaremos a distribuição a partir de alguns critérios específicos da realidade francesa na década passada, ou seja, em relação à fase mais aguda da crise, à reestruturação industrial e a valorização dos recursos técnico-científicos locais.

A crise abateu fortemente, primeiro as regiões Norte e Lorena, e, em seguida, as do Sul e do Oeste, onde estavam mais adensadas as indústrias fordistas, como as siderúrgicas, têxteis e automobilísticas. Na primeira metade da referida década, o desemprego chegara, em muitos Departamentos, a um nível superior à média nacional, 10,5\% (Mahieu e Mesplier, 1986), conforme o Mapa 11.

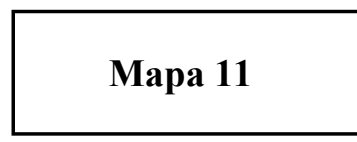

\section{O DESEMPREGO NA FRANÇA}

Por departamento - 1985

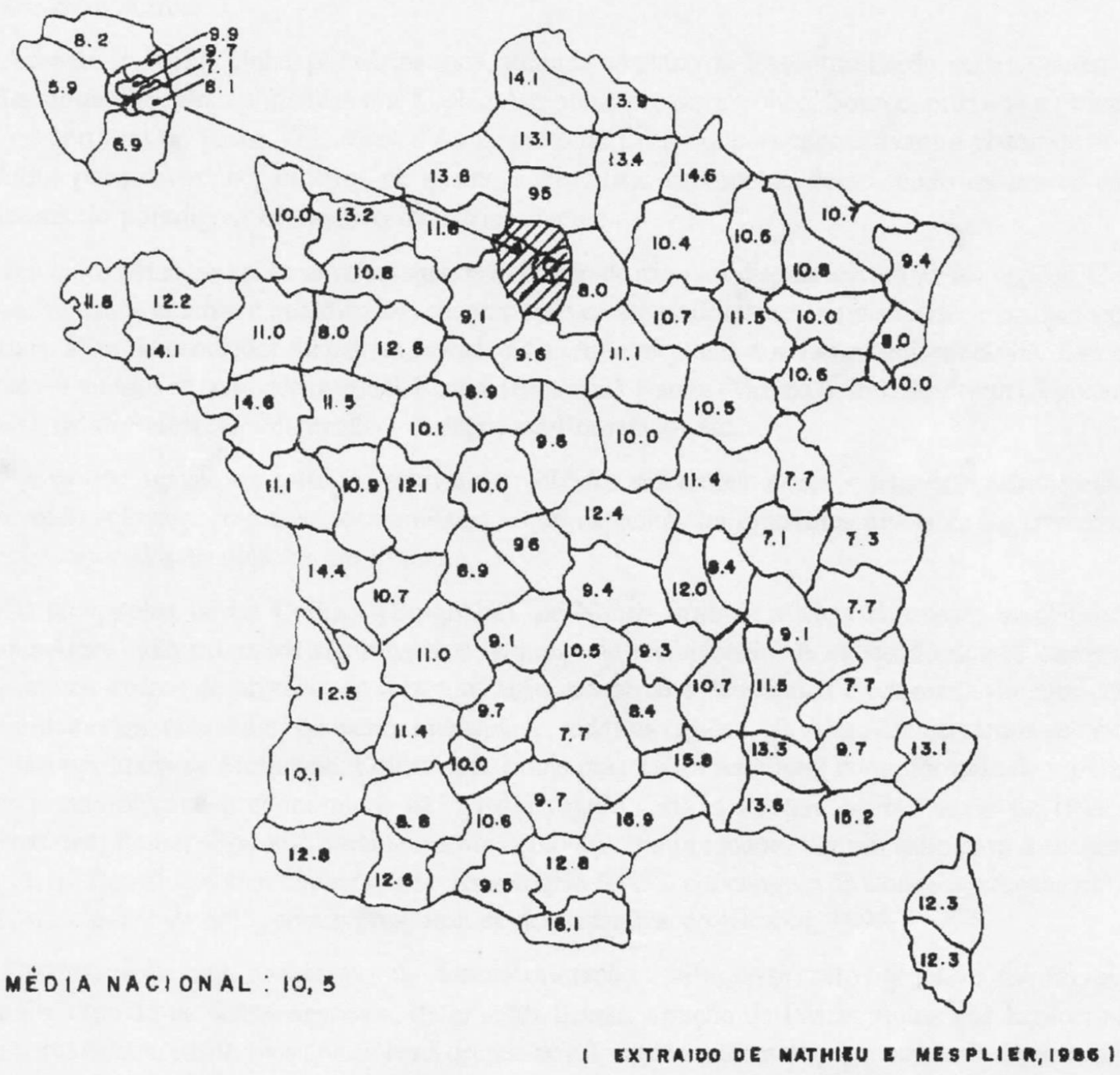

Várias medidas foram tomadas ou intensificadas pelo governo, por organismos públicos ligados à C.E.E., e pelas empresas, no sentido de arrefecer e reverter a crise que devasta quase todas as regiões: modernização das indústrias tradicionais, reciclagem da força-de-trabalho, implantação de 
infra-estrutura através de instalação de pólos de conversão ou reconversão nas regiões mais atingidas pelo desemprego. Muitos departamentos ou comunas, com essas medidas, visavam a atrair indústrias que pudessem amenizar a crise local.

Por outro lado, intensificou-se o deslocamento de instituições de ensino e pesquisa, de atividades produtivas das regiões mais densas para centros de menor expressão. Completarmente, outras medidas se dirigiam à reestruturação industrial: pesados investimentos em setores modernos - telecomunicações, aeroespacial, eletronuclear, eletrônico etc. que eram básicos para acompanhar a chamada Terceira Revolução Industrial. Dava-se mais atenção aos locais que já dispunham de experiência, de know-how nos setores de ponta ou com possibilidade de se voltarem à criação de empresas provenientes de transferência tecnológica. Alguns dos centros propulsores já vinham desenvolvendo programas ou setores de interesse estratégico-militar: Brest, na Bretanha; Toulon, na borda mediterrânea; Toulouse, no Midi-Pirineus; Grenoble, no Ródano-Alpes (Boisgontier e Bernady, 1985-b), entre outros.

Ademais, o País já vinha, por vários anos, atuando no plano da descentralização, com a construção de villes nouvelles, exemplificadas por Sophia Antipolis, próxima à Nice; Source, próxima a Orleans; Evry, na periferia de Paris, Villeneuve d'Ascq, perto de Lille - que se capacitavam a absorver novas atividades produtivas, organismos de ensino e pesquisa, criando-se desse modo os ingredientes locacionais do paradigma econômico industrial vigente.

Em outro plano, as ações se voltavam á valorização de recursos humanos altamente qualificados, concentração de atividades do terciário superior e equipamentos modernos, além de condições fundiárias favoráveis a explorar juntos aos campi universitários. Isso está presente nas cidades de comando regional: Rennes (Bretanha), Nantes (Vale do Loire), Bordeaux (Aquitânia), Toulouse (Midi-Pyrenées), Montpelllier (Languedoc-Roussillon) etc.

Nessa conjugação de esforços estavam envolvidos diferentes atores - setores governamentais, órgãos internacionais, empresas, comunidades - que capacitavam diferentes níveis de lugares para a territorialização dos tecnopolos em França.

Os tecnopolos de Le Creusot (Borgonha), de Nancy-Brabois e Mets (Lorena), SaintEtienne (Ródano-Alpes) são exemplos significativos de pólos de reconversão. A indicação desses casos não exclui muitos outros do objetivo de reestruturação industrial e econômica e retomada do emprego a que sr orientavam, com maior ou menor intensidade, todas as regiões. Na Alta Alsácia vamos encontrar a rede tecnopolitana de Mulhouse, Colmar e S. Louis (nas Três Fronteiras) como fórmula de reparar o potencial tecnológico e econômico; na mesma região, está o Parque de Inovação de Illkirch-Graffenstaten; Poitier (Poitou-Charentes) tenta como seu "Futuroscope" dar um salto para a economia terciária; na Picardia, com a Universidade Tecnológica (UTC) o tecnopolo de Compiège recebe muitas indústrias, a partir de 1983, com o programa de descentralização (Bruhat, 1990)

Paralelamente aos programas de descentralização, atingia-se outro objetivo favorável ao tecnopolo: atração de novos negócios, de grandes firmas, criação de PMEs juntos aos lugares para onde se orientaram, desde anos anteriores à década de 80 , alguns setores de pesquisa ou de departamento de $\mathrm{P}$ x D públicos e privados, formando-se os pólos de descentralização (Certaines, 1988). Entre estes são clássicos o de Sophia-Antipolis (Provence), a tecno-rede da Île-de-France-Sud, que procurava, entre outros objetivos, "favorecer a fertilização cruzada e a transferência de tecnologia, melhorando as condições de passagem da pesquisa fundamental à criação de empregos, encorajando a pesquisa e 
fazendo avançar o desenvolvimento industrial da inovação (Couvidat e Giusti, 1991, p. 209).

Outra linha de projeto que desembocou no que Certaines (1988) classifica de pólo de desenvolvimento, corresponde aos tecnopolos de Montpellier (Languedoc-Rossillou), Rennes-Atalante (Bretanha), Villeneuve d'Ascq (Nord), restringindo-se aos exemplos mais destacados. Eles se caracterizam por se edificarem sobre fortes bases preexistentes: amplos mercados, grandes universidades, potentes institutos de pesquisa, sólidas empresas engajadas em $\mathrm{P}$ x D, infra-estrutura urbana e regional e complexo mercado de trabalho com grande número de pessoas qualificadas, tudo isso geralmente encontrado nos mais importantes centros urbanos do País. Ao examinarmos a situação da rede tecnopolitana da França, detectamos um agregado de meia centena de lugares que vão de capitais regionais a pequenas comunas e cantões.

$\mathrm{Na}$ escala urbano-administrativa, tem-se tecnopolos em 12 capitais regionais e 9 em sedes de Departamento com número de habitantes superior a 100.000. Somente 5 desses centros são sedes regionais que contam mais de 500.000 habitantes: Nantes, Bordeaux, Tolouse, Marselha e Lyon.

Em cerca de 28 locais com número de habitantes inferior a 100.000, se espalha a totalidade ou parte dos equipamentos de vários tecnopolos, locais estes representados por capital regional (Poitiers com 82.900 hab.), capitais de departamentos, comunas e cantões com até 1.800 hab.

Alguns desses lugares são caracterizados pela presença de função militar ou de indústrias a ela ligada: aeronáutica e aeroespacial (Tolouse, Angers, Anglet, Nantes, Bayonne), pesquisa nucleares (Cadarache), indústria naval e base de submarinos nucleares (Brest) e arsenal de marinha (Toulon).

\subsection{A territorialização dos tecnopolos no Japão}

Desde o século XIX, com a inovação Meiji, (Okabe, 1974), o governo japonês procura adaptar à sua realidade temporal/espacial as inovações formuladas no contexto do capitalismo ocidental, destacando-se as políticas industriais.

No segundo pós-guerra, o Japão, inicialmente, teve sucesso com a adoção da política econômica de alto crescimento dos anos 60, mais precisamente, entre 1955 e 1973, baseado no paradigma fordista-taylorista, fase marcada por desigualdades regionais.

Logo, em seguida, e mais intensivamente nos anos 80, o País estabelece novo norteamento em seus planos, acompanhando o modelo difundido nos Estados Unidos e na Europa.

\section{a) Espacialidade}

No Japão, a implantação dos tecnopolos apresenta algumas especificidades dentre as quais se destacam: $1^{\circ}$ ) $\mathrm{O}$ Estado os adota dentro duma estrutura sistemática de política aplicada; $2^{\circ}$ ) os tecnopolos entram como componente estratégico do planejamento de desenvolvimento regional; $3^{\circ}$ ) os tecnopolos, em especial as cidades científicas, são usados como instrumento de descentralização demográfica, das unidades produtivas e dos equipamentos de $\mathrm{P}$ x D de Tóquio; $4^{\circ}$ ) na difusão dos tecnopolos, o aparato do Estado toma forma e funções diferentes das políticas anteriores, para acompanhar as transformações 
sociais e econômicas e minimizar as desigualdades regionais e disparidades de renda deixadas pelo boom de crescimento dos anos $60 ; 5^{\circ}$ ) o Plano Tecnopolis procura incentivar a instalação, a melhoria e a disseminação de instituições acadêmicas, como meio de capacitação técnico-científica das comunidades para melhor desenvolverem os investimentos privados nacionais e estrangeiros.

\section{b) O Plano Tecnopolis}

Surge no curso da fase mais aguda da recessão do capitalismo nos anos 80, por proposta do Conselho de Estrutura Industrial do Ministério do Comércio Exterior e Indústria (MITI), que aponta o Plano como meio de assegurar a continuidade e estabilidade da política industrial que vinha em crise desde os anos 70. Através de indústria de alta tecnologia desenvolvidas nos tecnopolos, seriam revitalizadas as indústrias tradicionais possibilitando-as à competição Internacional. Ademais, o capital nipônico se internacionalizava com rapidez, de tal modo que o Japão de 1985 se tornara a $1^{\circ}$ potência financeira do mundo (Futuribles, Juin - 1989: 49). O plano contrapunha-se à tendência da saída das empresas de microeletrônica e informática (Broadbent, 1990: 59) que poderiam impulsionar a modernização dos setores tradicionais do País.

Para Glasmeier (1989: 269), o Plano pode ser visto como "um complemento às políticas de desenvolvimento econômico nacional, projetado para orientar o modelo de crescimento econômico e espacial do país como um todo". Cônscio do papel da educação no desenvolvimento do País, especialmente com o avanço tecnológico atual, o governo, ao estruturar e disseminar uma rede de centros de inovação, se propunha à maior ênfase na instalação e melhorias dos estabelecimentos de ensino superior e técnico, uma clara decisão de externalizar a P x D, favorecendo o custo de produção do setor privado.

Destaca-se, nesse aspecto, a melhor qualidade das Universidades públicas para as quais o governo deu maior apoio, de acordo com o grau de sua importância para o esforço de modernização e industrialização (Amano, 1986: 19).

Embora o Japão contasse, em 1980, com 446 Universidades e faculdades, (muitas das quais do setor privado e de baixo nível,) no período de rápido crescimento econômico (19551970), o corpo de instituições acadêmicas não estava á altura de atender à elevada demanda da indústria: "após a II guerra, o desenvolvimento industrial foi tão rápido que as Universidades e Institutos de Pesquisas governamentais não conseguiram suprir as necessidades tecnológicas da indústria, que passou a desenvolver atividades de $\mathrm{P}$ x $\mathrm{D}$ com intensidade crescente. Em 1989, o Japão gastou com P x D 2,9\% do PIB, sendo 0,58\% a parcela do governo e 2,32\% a parcela das indústrias" (Vasconcelos, 1992: 367).

Com a redução do crescimento econômico nas três grandes metrópoles - Tóquio, Osaca e Nagóia - elevou-se o desemprego nacional e caiu a taxa de migração interna (Fujita, 1988: 583). O Plano Tecnopolis surge como "im instrumento inovador de desenvolvimento econômico e social das regiões menos prósperas no Japão" (Abe e Alden, 1988: 437). Para os centros urbanos dessas regiões são atraídos investimentos estrangeiros, à medida que incentivos governamentais são oferecidos, implantada pesada infra-estrutura, através de alguns ministérios. Assim, almeja o Plano a redução das desigualdades regionais, em especial no tocante à distribuição de renda.

Podemos afirmar que o Plano objetiva a: - reduzir a migração para as metrópoles, manter a população nas pequenas cidades e no meio rural, - evitar o êxodo de cérebros e de recursos financeiros (Kudoka), revitalizar a economia, - melhor distribuir a renda e - alocar as indústrias intensivas de 
conhecimento em ambientes mais tranqüilos, como pequenas cidades ou área rurais. Isso tudo se agregava aos interesses das empresas quanto à utilização de uma mão-de-obra sem tradição industrial, portanto mais "ordeira e mais barata".

De que meios se dispunham para efetivar o Plano? Que critérios foram estabelecidos para a localização desses meios? Ao MITI estavam associados outros Ministérios do governo central no sentido de atender aos múltiplos requisitos necessários a equipar uma cidade média de infra-estrutura e serviços capazes de torná-la um núcleo criador de inovações. Além disso, se dispunha estabelecer em cada um dos núcleos um órgão de investimento capaz de cobrir a demanda por capital de risco. Abatiam-se 15\% dos impostos das construções e $30 \%$ na compra de máquinas, e aboliram-se as taxas na compra de terrenos.

À prefeitura (província), o Estado central compensava com redução da taxa predial, além de oferecer assistência técnica e financeira, planejamento, marketing, arranjos com bancos para iniciativas locais. Para participar do Plano, a região deve dispor de centro urbano com uma média populacional de 200.000 hab., estar servida do sistema rodo-ferroviário e de aeroporto, além de possuir unidades de pesquisa e ensino com acesso às empresas, tanto para a formação de pessoal quanto no que se refere à elaboração de pesquisa aplicada.

Para construção do tecnopolo, os governos locais, em conjunto com representantes da indústria e das Universidades, estabeleceram uma organização específica para promoção tecnológica, sem fins lucrativos. Com recursos próprios e do Ministério da Finança, essas "organizações"realizam promoção das indústrias locais: coordenam a articulação P x D com indústrias, universidades e governo; "joint-ventures"; proporcionam treinamento da forçade-trabalho das PMEs e administram pesquisa social sobre os efeitos dos tecnopolos na comunidade local, (Fujita 1988: 569).

A prerrogativa da descentralização não exclui, no entanto, a pujante centralização das grandes metrópoles do País, especialmente pela força das transações requeridas pela desintegração vertical de firmas cujas sedes de comando mantém-se nas maiores aglomerações.

Essa articulação da rede é facilitada pelas vias de transportes presentes (aéreo, rodoferrovia e hidrovia) e os mais evoluídos sistemas de rede de informação tecnológica como o TECHNO - MARKET (Benko, 1990: 101), que "é baseado num sistema on-line conectando as três grandes metrópoles com as áreas de tecnopolo" (Fujita, 1988: 569), o que possibilita a transferência e a troca de tecnologia.

Essas facilidades de articulação (com apoio do MITI, agências de PMEs e demais Ministérios) fortalecem a preferência locacional de firmas subcontratantes, joint - ventures, PMEs especializadas com melhores ofertas de produtos intermediários por essas regiões periféricas, dadas às incertezas do mercado, forte concorrência nas grandes aglomerações japonesas (Benko, 1991 - b).

Além do mais, as regiões periféricas apresentam vantagens comparativas em função das terras e salários de preços muito inferiores aos das metrópoles, favorecendo a descentralização almejada pelo governo (Kesteloot, 1990).

\section{c) A localização dos tecnopolos}

O arquipélago nipônico desenha no mapa um arco com uma largura aproximada de $15^{\circ}$ de longitude, na faixa dos paralelos que emolduram a Europa meridional e a Califórnia; no extremo sul, 
flexionado para a península coreana, fica a ilha de Kyushu ou Silicon Island, mirando-se no Silicon Valley, situado no outro extremo do Oceano Pacífico (Mapa 12).

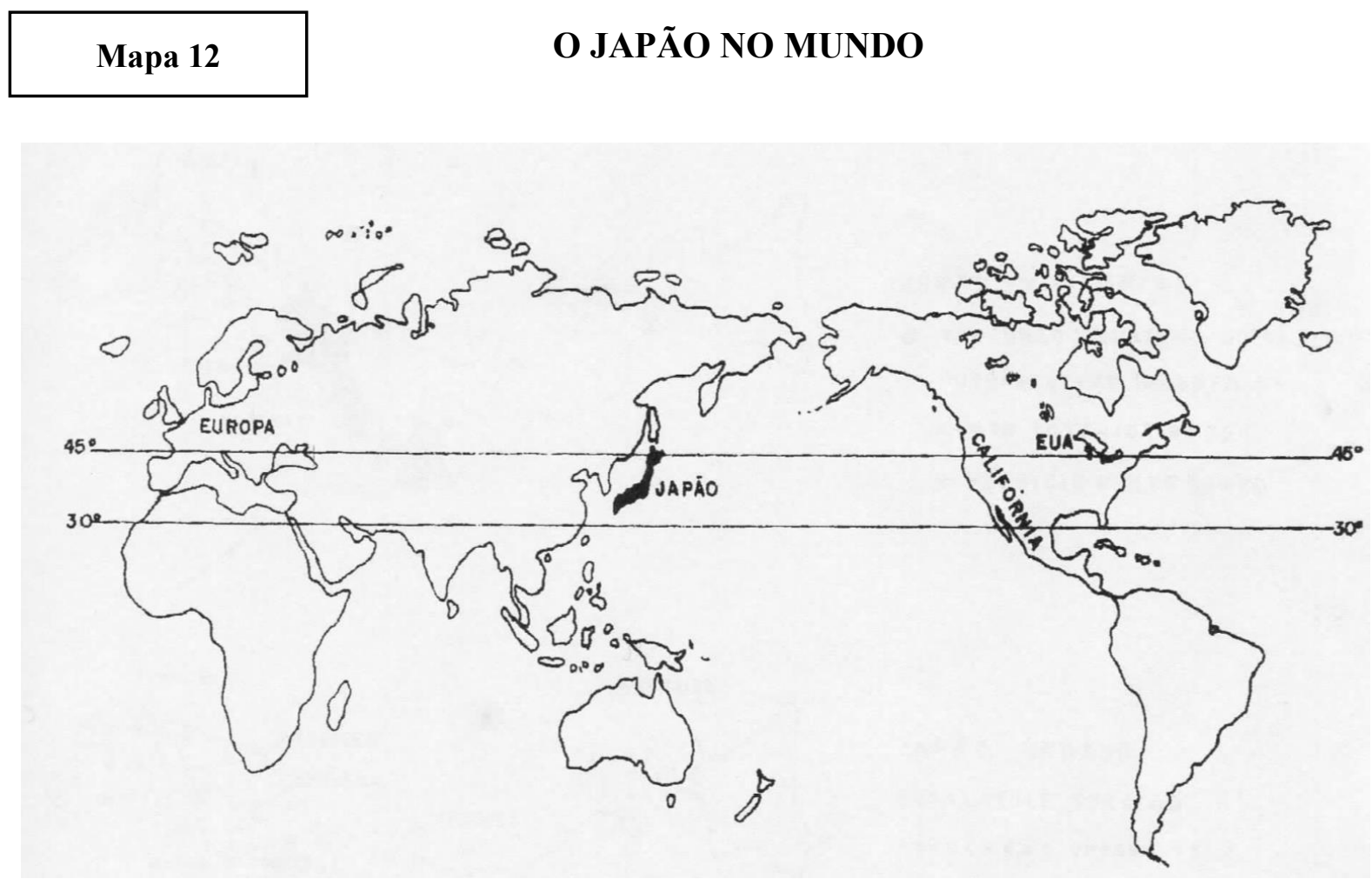

Com a execução do IV Plano de Desenvolvimento Nacional Integrado que visa à descentralização das atividades econômicas de Tóquio, as quatro ilhas estão integradas por túneis e pontes. Honshu, a principal e maior das ilhas, está ligada a Hokkaido pelo túnel Seikan, a ponte e o túnel Kanmon a conectam com Kyushu, enquanto a interligação com Shikoku se faz por um conjunto de seis pontes, entre Kojima e Sakaide, percurso conhecido como Seto Ohashi. (Japão Ilustrado, v. II, n¹, 1988).

$\mathrm{Na}$ parte média do litoral leste da ilha de Honshu está o maior adensamento urbanoindustrial do País, (mapas 13 e 14) esboçando a megalópole de Tokaído. Esta concentração de grandes metrópoles se estende da esquina da região de Kanto à região histórica de Kinki ou Kansai, tecida pela conurbação de Tóquio-Nagóia-Kioto-Osaka-Kobe no alinhamento do paralelo $35^{\circ} \mathrm{N}$.

A descentralização proposta pelo governo com o Plano Tecnopolis, em 1982, procurava incentivar as Prefeituras mais afastadas de Tokaído, a criarem condições propícias a um meio técnico-científico informacional.

Do Plano do MITI, nasceram dezenove áreas tecnopolitanas - (mapa 16) - ora limitadas em cidade nova ou em distritos marshalianos, (mapas 15 e 16) ora ampliadas em tecno-redes com um conjunto de núcleos urbanos, definindo-se como tecnópoles. Rarefazem-se na parte setentrional do País - Hakodate na ilha de Hokkaido, Akita e Aomori na ilha de Honshu contrariando o adensamento encontrado no Sul. Na porção central da ilha de Honshu, 2 tecnopolos-Utsunomiya e Hamamatsu - se confinam respectivamente nas proximidades de Tóquio e Nagóia, e 2 outros - Toyama e Nagaoka - se 
localizam na faixa ocidental banhado pelo mar do Japão. Na porção arqueada para as proximidades do bloco continental está uma dúzia desses pólos, seis do quais estruturam a Silicon Island ou Kyushu. Relacionaremos esse conjunto de áreas técnico-científicas informacionais, seguindo as indicações contidas no Atlas International des Technopoles, de Yan Couvidat et Julien Giusti (1991). Além dessa fonte, outras serão indicadas do desenvolvimento do estudo.

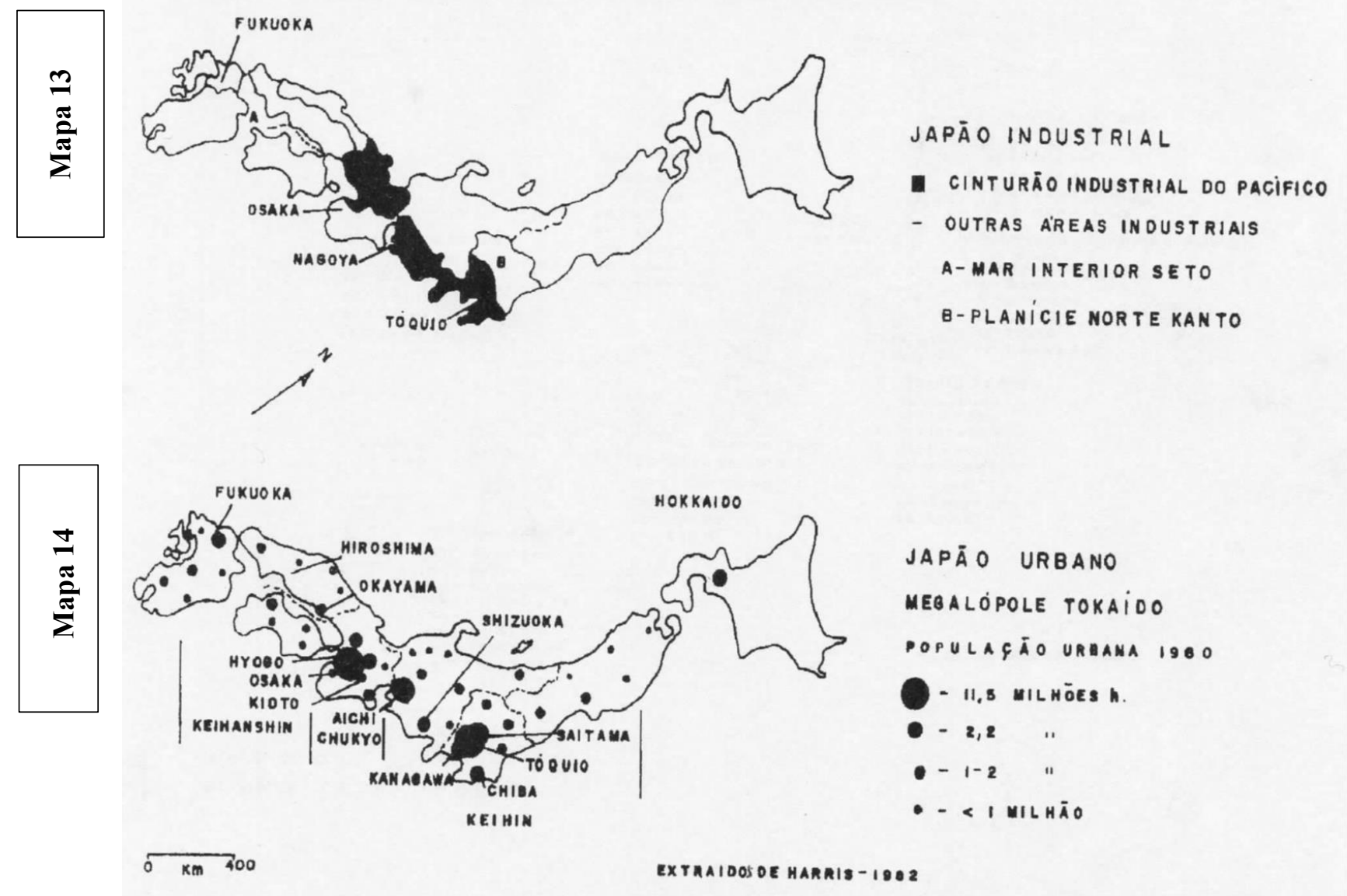

I - Na cidade de Hakodate (320.000 hab.), no sul da ilha de Hokaido, está sendo construído ex-nihilo, o tecnopolo na zona oeste, a mais antiga zona urbana (Japão Ilustrado, V. $10, n^{\circ} 2,1987$ ), com a finalidade de soerguer a economia local, dada a crise em que está o antigo estaleiro.

A nova industrialização pretende desenvolver três setores: construção naval, indústria agro-alimentar marinha e as tecnologias do frio (material de entretemento, máquina de transporte etc.) em quatro zonas industriais. Cinco instituições de $\mathrm{P} \times \mathrm{D}$ apoiaram as inovações demandadas pela atual fase de modernização. Hakodate liga-se à ilha de Honshu, através do túnel submarino Seikan, por onde passam as modernas ferrovias e rodovias.

II - Aomori, na baía de Mutusu da região Tohoku, é a principal cidade do extremo norte de Honshu, com 287.000 hab. Ela não participou do crescimento dos anos 60-70, sendo então motivo de atenção dos planejadores do MITI. Apesar de não dispor de centro de pesquisa importante e estando a Universidade de Hirosaki distante $20 \mathrm{~km}$, Aomori se propõe a atrair unidades subcontratantes de empresas de outros tecnopolos. Desse modo, aí se desenvolveriam atividades que utilizariam recursos 
locais, (agricultura e pesca), as vantagens comparativas baseadas em baixo preço dos salários e dos terrenos, além da energia de 2 centrais nucleares. A indústria de whisky japonesa Suntory, já no local, ampliará sua destilaria com um centro de P x D, ação acompanhada pela indústria química Sumimoto.

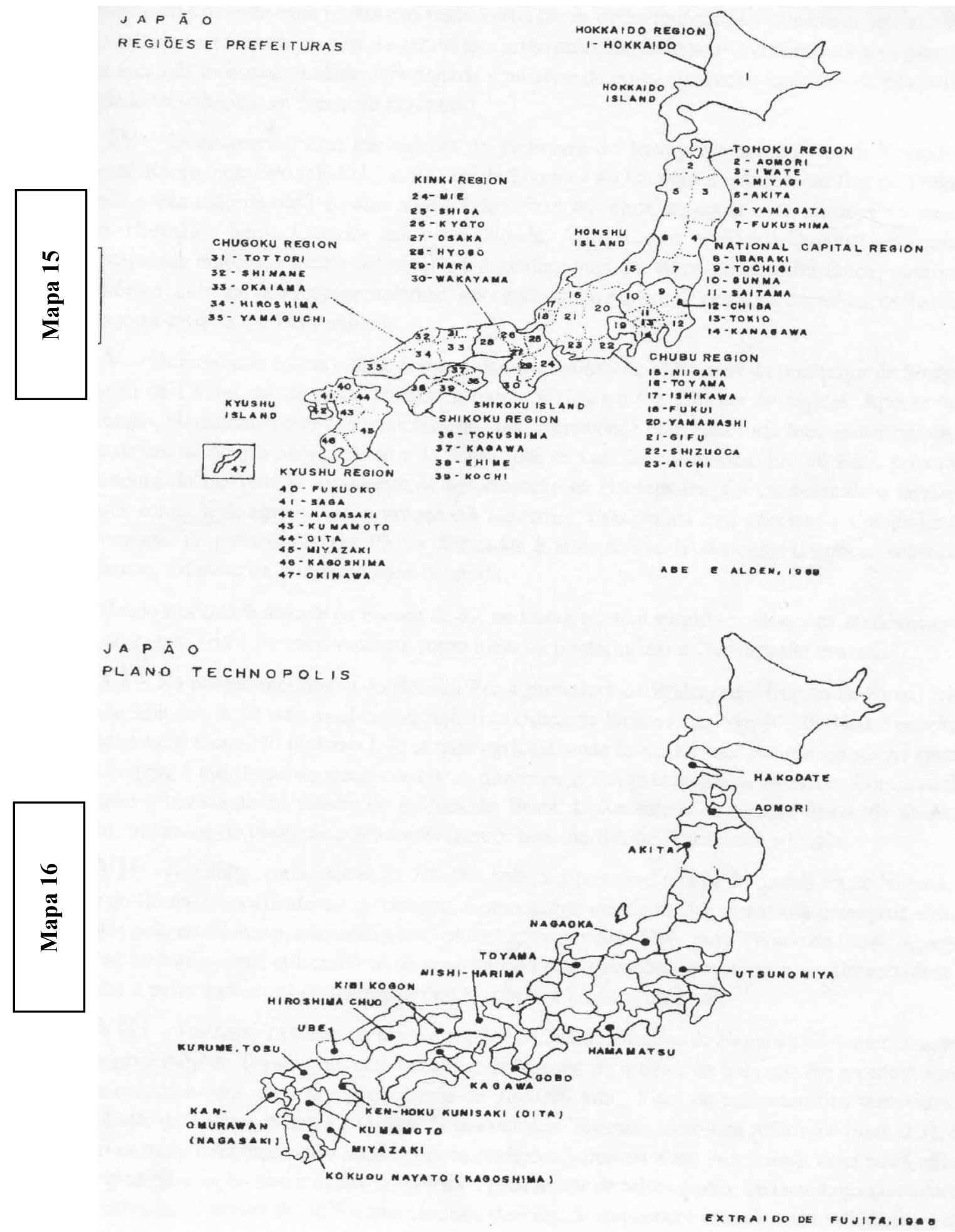


III - Na mesma região e com efetivo populacional semelhante a de Aomori, Akita tem participado do novo ciclo econômico, desde os anos 80, com a inauguração do aeroporto internacional e a instalação de 2 grades empresas: Nippon Electric e Akita-Denshi com spinoff de inúmeras PMEs e PMIs. Aproveitando a mão-de-obra barata e as tradicionais fontes de energia eólica e geotérmica, as indústrias presentes, como a Mitsubishi Metal e outras que serão atraídas, terão seus territórios a baixo preço nas novas áreas do tecnopolo: cidade unversitária com zona de lazer: comércio, institutos de pesquisa ou na cidade tecnológica em frente ao aeroporto.

IV - Utsonomya é uma das cidades da prefeitura de Tochigi na borda norte de Tokaido, na região de Kanto, com 390.00 hab., a $100 \mathrm{~km}$ de Tóquio e $40 \mathrm{~km}$ para a cidade cientifica de Tsukuba, de onde capta mão-de-obra de alto nível. Além disso faz parte do cenário de parques nacionais - Nikko, Hiobara e Nasu. Grandes indústrias (Honda, Aiwa, Canon e NipponDupont) em conjunto com pequenas empresas locais desenvolvem trabalhos nos domínios da optoeletrônica, eletrônica, mecatrônica, química fina e novos materiais, aproveitando os centros de pesquisa cientifica, os institutos de pesquisa médica e a Universidade.

V - Hamamatsu é uma cidade costeira de meio milhão de habitantes da prefeitura de Shizuoka da região de Chubu, na faix de Tokaído próximo à Nagoya e a $250 \mathrm{~km}$ da capital. Apesar dessa localização, Hamamatsu tem boa qualidade de vida, convivendo com uma forte base industrial que e utiliza de um aeroporto internacional e da densa rede de vias de transportes. Em $50 \mathrm{~km}^{2}$, próximo à embocadura do rio Tenryu, a noroeste de aglomeração de Hamamatsu, foi estabelecido o tecnopolo com três zonas: a de agricultura, a urbana e a industrial. Esta ultima está próxima à Universidade e departamento de pesquisa e com PMEs dedicados à informática, biotecnologia, óptica, sistema de informação, informática e instrumentos de corda.

Desde a primeira metade da década de 80, no tecnopolo têm surgido associações acadêmicas nas áreas de engenharia e ciências médicas como meio de potencializa a "fertilização cruzada".

VI - Na porção meridional de Honshu fica a prefeitura de Wakayama (região de Kinki) frente a ilha de Shikoku. A $30 \mathrm{~km}$ ao sul da sua capital (a cidade de Wakayama, com 400.000 hab.) encontra-se a cidadela de Gobo (30.000 hab.), de caráter agrícola, onde fontes termais e clima agradável ajudam o cenário para a instalação do tecnopolo que se destinará às novas tecnologias da saúde. Com esse fim, projeta-se a instalação de Centro de reeducação física, Universidade de terapia física, de medicina oriental, institutos de pesquisa e desenvolvimento, com auxílio de Wakayama e Osaka.

VII - Nagaoka, com menos de 200.000 hab., é a principal cidade da prefeitura de Niigata, na região de Ohubu, faixa ocidental de Honshu. Como antiga cidade feudal, apresenta paisagens idílicas drenadas pelo rio Shinano, enquanto como entroncamento viário ( $2 \mathrm{~b}$ para Tóquio de trem), agrega o moderno ao tradicional, utilizando-se das inovações provenientes da Universidade de Nagaoka e pelas indústrias de microeletrônica, robótica e microrobótica.

VII - Toyama. Também pertence à região de Chubu, a mesma de Nagaoka e Hamamatsu, mas está na prefeitura de Toyama, no lado ocidental de Honshu no interior da baia que lhe recebe o nome. É uma cidade média, com um pouco mais de 300.000 hab., local de entrocamento ferroviário e equidistante de Tóquio, Nagóia e Osaka. O que destaca Toyama, como nos referimos (item 3.3), é a decisão de suas lideranças em romper com as tradições culturais e até redefinindo uma nova cidade tecnológica na criação de um centro de 100 ha para trocas de informações, de tecnologias e técnicas. Nesse caminho, o tecnopolo de Toyama já atraiu dezenas de empresas e estendeu sua influência, o que 
tem levado os planejadores a definirem a tessitura de uma tecno-rede com 14 zonas nos domínios da Química, bio-indústrias, biorrobótica e robótica.

IX - A prefeitura de Hyogo na região de Kinki, se estende do mar do Japão ao mar Interior. Harima é o nome dada à planície costeira da cidade histórica de Himeji, no mar Interior, onde será construído o tecnopolo Harima Oeste, a menos de $50 \mathrm{~km}$ da aglomeração de Kobe. Esse espaço litorâneo é densamente povoado, contando já com a presença de múltiplas instituições universitárias e de indústrias ligadas à robótica, inteligência artificial, eletrônica médica, biotecnologia, microcerâmica. A paisagem de castelos feudais do século XIV-XV será sucedida por outra fisionomia arquitetônica do pós-moderno.

$\mathbf{X}$ - A menos de $100 \mathrm{~km}$ a oeste de Himeji, encontra-se o antigo centro têxtil DE Honshu, Okayama, cidade histórica de 550.000 hab., cuja prefeitura tem o mesmo nome, região de Chugoku. Nas suas imediações construiu-se a cidade nova de Kibi dedicada à $\mathrm{P}$ x D de bioindústrias (banco de enzima/bactéria, centro experimental da vida etc.) com a estreita colaboração da Universidade de Okayama e a Faculdade Okayama de Ciência.

A primeira parte de Kibi foi aberta em 1987, com zonas de resistências, centro comercial e um complexo dedicado a saúde e tratamento.

XI - Seguindo ainda mais para oeste de Okayama, na baía e prefeitura de mesma denominação, chega-se à famosa cidade de Hiroshima (899.000 hab.), cujo tecnopolo se amplia para a ativa cidade portuária de Kure (234.600 hab.) Hiroshima se destaca por seu complexo industrial da eletrônica: 1.200 empresas relacionadas a computadores, 35 sociedades de produção e venda de software, 33 empresas comerciais de eletrônica e informática. Em seus arredores, a tecno-cidade acadêmica de Higashi hospeda a Universidade, 27 institutos de pesquisa com pessoal altamente qualificado, à semelhança da cidade científica de Tsukuba, próxima de Tóquio (Japão Inlustrado, v. 10, nº 3, 1987).

A cidade de Kure, a sudoeste de Hiroshima, oferece o complemento do tecnopolo, com o espaço de bom clima e excelente qualidade de vida.

XII - Oterceiro tecnopolo na região de Chugoku é o Ube-Yamagushi, prefeitura de Yamagushi, no extremo sudoeste da grande ilha de Honshu. Surge como pólo de reconversão de um decadente complexo industrial, tipicamente do modelo fordista (metalurgia, cimento, vidro, petroquímica etc.) que se espalha por estas duas cidades e mais sete comunas. Yamagushi - capital da prefeitura - é um antigo centro urbano interiorizado com um efetivo demográfico de 115.00 hab. Seu projeto é aproveitar a vantagem comparativa de terrenos disponíveis e baratos e a característica de ambiente propício ao lazer, além de um relativo esfroço de pesquisa da Universidade de Yamagushi, cujos resultados têm sido aproveitados pela indústria automobilística Mazda Motores ou Toyo-Kogyo.

O projeto do tecnopolo, com 155 há. De terreno para novas indústrias, é orientado para instalar e desenvolver órgãos de $\mathrm{P}$ x D nos domínios de novos materiais (novas cerâmica, plásticos, fibras de vidro, aço etc.) e um centro para feiras, congressos, biblioteca. Espera-se que até 1995 cerca de 53.000 empregos sejam nessa parte do Japão.

XIII - Na ilha de Shikoku só há um tecnopolo: no litoral NE do Mar Interior ou Setonaikam, ponto de passagem obrigatória de todas as comunicações que vêm de Honshu. É aí onde sse ergue Takamatsu (299.000 hab.), de Kagawa, conhecida por seu potencial turístico, administrativo e 
e comercial. A área prefeitural é de terras férteis e ensolaradas, tendo ainda aproveitamento da água do mar com uma fábrica de coleta de urânio, além de central nuclear e solar á prova de terremoto.

Não dispondo de pessoal para pesquisa e ensino na Prefeitura, foi necessária a criação de uma rede social de velhos habitantes, no emprenho de forçar os filhos da região que se qualificarem e estão noutras terras a retornarem ao seu local de origem. Desenvolve-se esforço em vários domínios: energia nuclear, mecatrônica, comunicação, novas técnicas agrícolas, piscicultura, uma unidade $\mathrm{P} \times \mathrm{D}$ de biomédica, espalhando-se do litoral às montanhas Sanuki, no centro de Shikeku.

\section{A Silicon Island}

A ilha de Kyushi, em relação ao conjunto territorial e aos aspectos industriais do Japão, guarda algumas singularidades, o que nos exige, preliminarmente, breves observações.

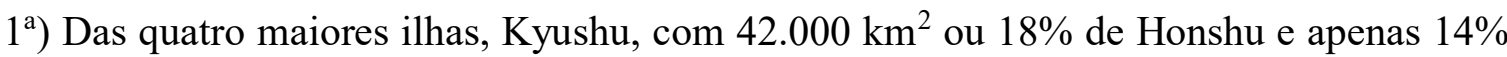
de sua população, é a que mais se aproxima do território dos países mais dinâmicos da Ásia: para a Coréia se volta a aregião Norte onde estão as cidades industriais de Fukuoca e Kitakyushu; na borda ocidental, Kagoshima e Humamoto têm em sua frente a populosa Shangai; o Sul, com Kagoshima, se estende em direção a Taiwan, Hong-Kong e Filipinas.

$2^{\text {a) }}$ Distanciada do Pacific Industrial Belt e ainda su-industrializada nos anos 60-70, Kyshu dispõe de alguns pontos com tradição industrial desde o século XIX, (Fukuoka, Kitakyushu) comportando-se como receptores de mão-de-obra das prefeituras menos dinâmicas que também alimentavam o grande adensamento da megalópole Tokaido (Harris, 1992; Fujita, 1988; Kestoot, 1990).

$3^{\circ}$ ) Com a crise a partir dos anos 70 , diferentes mudanças ocorreram na ilha: queda brusca das indústrias carboníferas, siderúrgicas e estaleiros nas prefeituras de Fukuoka e Nagasaki, cuja mão-de-obra, em parte,, passava para o setor terciário; repercussão mundial do desastre ecológico de Minamata, em Kumamoto; emigração do Norte para a região de Tokaido; início de instalação ao do País, das terras 70 a $80 \%$ mais baratas que nas três grandes metrópoles nacionais; ação desenvolvimentista de organizações regionais com incentivos do governo. (Fujita, 1988).

$4^{a}$ ) "Kyushu tornou-se a Silicon Island do Japão, mas ao contrário do complexo californiano, não se trata de lugar de $\mathrm{P}$ x D. São zonas rurais, não submetidas às transformações sociais da industrialização, mas exploradas para fornecer $40 \%$ da produção de semi-condutores japoneses ou 10\% da produção mundial "(Kesteloot, 1990: 53). E, nesse sentido, o plano de descentralização com os tecnopolos tem sido visto com um instrumento inovador de desenvolvimento regional (Abe e Alden, 1988). Em 1980, Kyushu foi designada como orla do Pacífico Industrial, em razão da presença de base espacial, de energia nuclear e d armazenamento de petróleo.

Desse modo, Kyushu absorveu um terço dos tecnopolos definidos pelo MITI, distribuídos por todas as suas sete prefeituras:

XIV - Prefeitura de Oita: é uma tecno-rede de 19 municipalidades e comunas, (como ocorre em Lyon, França e em San Diego, EUA), comandadas pelas maiores cidades: Oita, a capital, e Beppu. 
Essa preferencia pela disseminação de PEs e de micro-processadores na zona contrapõe-se ao que ocorrera no anos 60-70, quando Oita foi considerada como nova cidade industrial e recebia a implantação de grandes e modernas refinarias, complexo petroquímico e siderúrgico. Essas ações desenvolvimentistas, no entanto, não resultaram em melhorias sociais (educação, moradia e emprego). Em fins dos anos 70, o governo local se volta às indústrias HT, e logo depois entra no Plano Tecnopolis, além de implantar um Distrito Industrial específico para indústria "de ponta".

Malgrado as inúmeras indústrias presentes, as estatísticas revelam que a automação e a robotização têm reduzido a absorção de mão-de-obra, embora se tenha estabelecido na zona rural da península de Kunisaki, nas proximidades de um grande aeroporto, uma miríade de empresas "de ponta" (Broadbent, 1990: 61) e mais de 40 aglomerados de tecnologia avançada (Japão Ilustrado v. 10, $\mathrm{n}^{\circ} 1,1987$ ).

XV - Prefeitura de Miyazaki. A CIDADE (CAPITAL) Miyazaki (296.000 hab.) é o núcleo do Tecnopolo do Sol, a Côte d'Azur do Japão, na porção sudeste de Kyushu, na planície litorânea do Rio Oyodo que deságua no Pacífico. Por sua beleza, a literatura lhe dá a expressão The Land of Sunshine and Greenery. Energia hidrelétrica abundante, infraestrutura de transportes excelente, mercado, terrenos livre, 2 aeroportos e 3 portos em águas profundas e setor terciário desenvolvido, além de Universidades e uma Faculdade de Medicina são condições ótimas para atrair empresas nos domínios de semi-condutores, bioquímica, robótica e micro-cerâmica.

XVI - Prefeitura de Kagoshima, no extremo sul. O tecnopolo ocupa espaço entre as pequenas cidades de Hokubu e Haiato na curva mais interior da baía, servindo pelo moderno sistema rodoviário que liga, num circuito de $135 \mathrm{~km}$, a capital Miyazaki.

A cidade de Kagoshima, (505.000 hab.) é famosa por seu porto internacional, pela mais importante estocagem de petróleo do mundo e por sua Universidade. Além das indústrias tradicionais e do artesanato de cerâmica e porcelana encontrados na região, o tecnopolo tem suas empresas voltadas à tecnologia espacial e de comunicação, semi-condutores, robótica e robótica médica.

XVII - Prefeitura de Kumamoto. Ocupa a fachada central da parte ocidental da ilha, tendo sua capital, na baía de Ariake, numa planície afastada do litoral, distante $221 \mathrm{~km}$ de Kagoshima e $129 \mathrm{~km}$ de Oita. Tem como atrações regionais as florestas sagradas e o vulcão Arosan. É intensa a atividade técnico-científica de Kumamoto: três universidades com cursos de engenharia e eletrônica, berço das 2 empresas gigantes de microprocessadores (Nippon Electric e Mitsubishi Eletric) que geraram spin-off de 300 empresas, laboratórios de pesquisa, centros de pesquisa, centros de colóquios, comercialização de produtos eletrônicos.

Outros domínios: biotecnologia, com grandes PMEs, no setor de vacina e medicina anticâncer; processamento de dados. A Honda de motocicleta é a única automobilística em Kumamoto.

XVIII - Prefeitura de Nagasaki. Ocupa a extremidade de uma península mais a noroeste, por isso porta do comércio exterior desde o século XIV, sendo, atualmente, o maior porto petrolífero do Japão, além de manter ativo seu estaleiro. A prefeitura conta com 2 cidades importantes: a capital Nagasaki (430.000 hab.) e, a $88 \mathrm{~km}$ Sasebo (252.000 hab.) que desenvolve a indústria de energia para a produção de bens ligados à alta tecnologia. Em Nagasaki funcionam institutos de ciências aplicadas e a universidade que desenvolve pesquisa oceanográfica, mecatrônica e novos métodos de comunicacão.

XIX - Prefeitura de Fukuoca e Saga. O tecnopolo situa-se em 2 cidades conurbadas dessas 
prefeituras: Kurume com 217.000 hab. (Fukuoca) e Tosu (Saga) com 116.000 hab. Na planície a $20 \mathrm{~km}$ da foz do rio Chikugo na baía de Ariake, no noroeste de Kyushu. Esta zona tecnopolitana engloba 5 cidades satélites e é o único tecnopolo com 2 redes prefeituras, mas com uma única identidade cultural e geográfica, pois o norte, desde séculos, é uma destacada rota cultural. Outra particularidade de Kurume é ser berço de algumas grandes indústrias do setor de borracha. A vida universitária é muito ativa, a $2^{\text {a }}$ região do País, reputada pela qualidade de suas investigações da estação nacional de pesquisa e experimentação de leguminosas, da unidade de estudo e pesquisa dos medicamentos, das agências das ciências e seis modernas rodovias nacionais. Fukuoca, onde termina a linha de Shinkansen (trem bala) é um dos mais importantes centros urbanos da região, está a $30 \mathrm{~km}$, aproximadamente, de Kurume.

Esse tecnopolo é mais centro de P x D que de produção.

\section{d) Tsukuba}

Antes do Plano Tecnopolis, ainda em plena fase de alto crescimento do pós-guerra, os dirigentes nacionais do Japão se decidiram construir ex-nihilo uma cidade científica nas proximidades ddda capital. A deseconomia de aglomeração de Tóquio levara, em 1962, o comitê de Problemas Urbanos a sugerir a construção de uma cidade que acolhesse parte das atividades de P x D, além de aliviar a superpopulação da metrópole. Decidiu-se implantá-la ao sul da prefeitira de Ibaraki, $60 \mathrm{~km}$ a noroeste de Tóquio e $40 \mathrm{~km}$ do aeroporto internacional de Narita, num lugar de antigo arrozal, circundado pelo lago Kasumigaura e o monte Tsukuba que dera nome à futura cidade (mapas 17e 18).

Só a partir de 1965, teve início o Projeto de aquisição das terras e a indicação de HUDC (Sigla em inglês de Corporação de Desenvolvimento Urbano e da Habitação) como executor, apoiado por vários órgãos do governo central. Conforme dados de 1990 do HUDC, a cidade tem uma área total de 28.500 ha. Dividido em 2 setores (mapa 18): o Distrito de Pesquisa e Educação (DPE) instalações comerciais e moradias dos quais 80 hab. Reservados para o core urbano, onde se desenvolvem as atividades culturais, comerciais e administrativas. A área ao redor do DPE é chamada de Distrito suburbano (DS) cuja ampliação se dará de acordo com o crescimento do DPE, especialmente com a relocação de instituições e indústrias, sempre ligadas à promoção do crescimento da cidade científica, mantendo-se um meio ambiente saudável e a agricultura suburbana como atividade tradicional da população.

As principais rodovias são três norte-sul e seis leste-oeste que interligam os distritos e cidades vizinhas, entre as quais a moderníssima Joban, que une Tsukuba a Tóquio.

Em 1972, foi inaugurado o $1^{\circ}$ Instituto Nacional de Pesquisa de Material Inorgânico, em 1973, dera-se a abertura da Universidade de Tsukuba, sucedendo-se daí em diante o funcionamento de dezenas de institutos de pesquisa e demais equipamentos.

A partir de 1982, Tsukuba é objeto de visita de renomados dirigentes estrangeiros, como Mittterand e Tatcher. Em 1989, sua população era de 162.000 hab. E no início da década de 1990 contribui com pessoal altamente qualificado para outras áreas técnico-científicas, como Utsunomiya.

No início dos anos 80, o Prof. Takahashi, da Universidade de Tsukuba, apresentava uma série de problemas da cidade, mas ressaltava as perspectivas de a cidade científica "tornar-se um excelente 


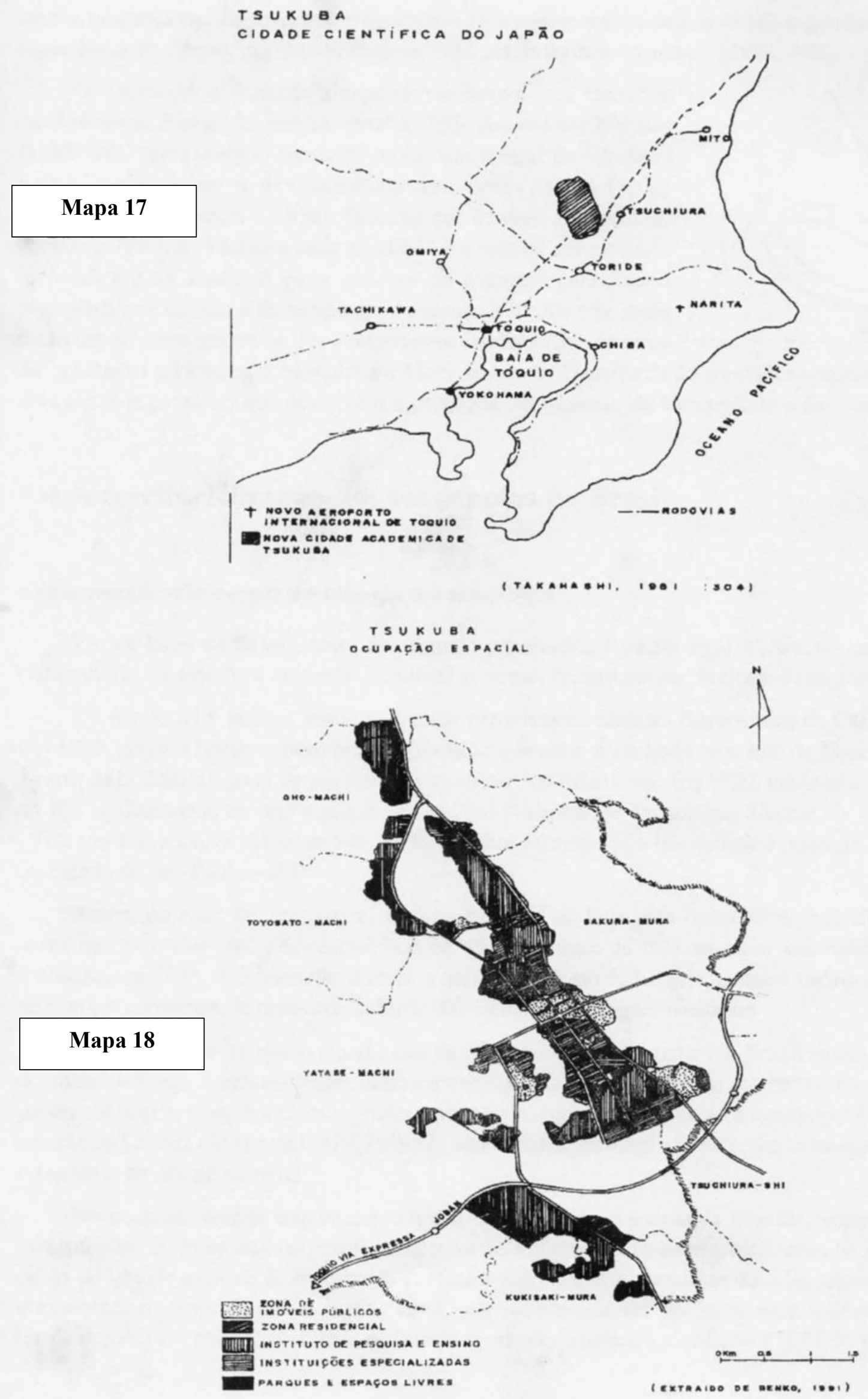


centro internacional de pesquisa, trabalhando atualmente com ciência natural, engenharia e ciências agrícolas e, no futuro, ciências biológicas, humanas e sociais"/ (1981: 306).

Os japoneses traduziram a importância desta cidade científica no símbolo da Exposição Internacional de 1985, descrita por Mihaues (1983: 90): "este símbolo (ao lado) representa o ideal da interação harmoniosa do universo, da humanidade, da ciência e da arte. $\mathrm{O}$ pico do triângulo representa o Monte Tsukuba que domina a Prefeitura, situado a $79 \mathrm{~km}$ de Tóquio e onde se edifica o Campus universitário mais célebre do Japão. A parte superior do triângulo simboliza a emergência da ciência e da tecnologia do século XXI. Os três

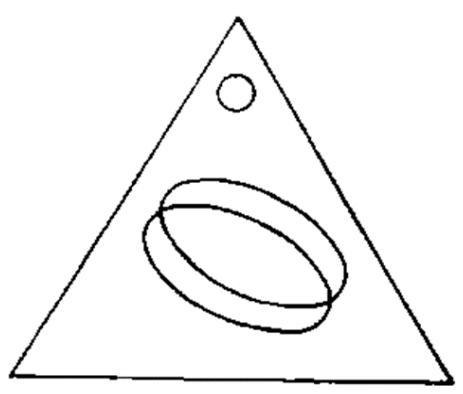
lados do triângulo representam os três componentes fundamentais do tema da exposição: o Homem, a Moradia e o Meio Ambiente. O conjunto do símbolo é completamente por dois círculos paralelos que descreve o progresso harmonioso da humanidade e da ciência".

\subsection{A territorialização dos tecnopolos no Brasil}

\section{a) Formação do corpo de ciência e tecnologia}

Vários fatos o Brasil, antes do segundo pós-guerra, tiveram significativa importância como elaboradores da estrutura do corpo científico nacional. Dentre outros, realçam-se os seguinte:

No século XIX vinham sendo realizadas pesquisas na Estação Agronômica de Campinas, IAC. Em 1900, surge o Instituto Socoterápico, no Rio de Janeiro, mais tarde chamado de Manquinhos, mas a partir de 1908 teria o nome de seu mais ilustre diretor, Oswaldo Cruz. Em 1920, funda-se a Universidade do Rio de Janeiro, no ano seguinte, o Instituto Nacional de Tecnologia. Depois da Revolução de 1930, é criada a Universidade de São Paulo e melhor estruturado o Instituto de Pesquisa Tecnológicas do Estado de São Paulo - IPT.

Assim, no início do pós-guerra, se fazia presente no País uma comunidade científica capaz de ações que hoje têm profundas influências em vários setores da vida nacional, exemplificando com a fundação em 1948, da Sociedade Brasileira para o Progresso da Ciência, o maior forum de discussão, de postura coerente e de defesa da cultura, das ciências e das artes nacionais.

Era uma época em que o mundo saía de uma guerra extravagante e o Brasil ainda se refazia do pesadelo de longa ditadura. Nesse novo cenário, o País, preocupado em manter-se no convívio dos países vitoriosos e hegemônicos, começa a montar a estrutura de ciência e tecnologia (CeT), com a criação do CNPq (1951) e da CAPES (1952), no intuito de formação de recursos humanos a serviço da pesquisa e do ensino superior.

No início da década seguinte, é criada a Universidade Nacional de Brasília, importante centro incorporador de pesquisas no ensino universitário. Malgrado a fase de cerceamento da liberdade e a perda de grande número de renomados professores e cientistas, nas duas décadas seguintes tivemos importantes medidas de cunho institucional, que vieram acentuar as bases para o desenvolvimento técnico-científico: criação do Fundo de Desenvolvimento TécnicoCientífico - FUNTEC (1964), cinco 
anos depois substituído pelo Fundo Nacional de Desenvolvimento Científico e Tecnológico, (FNDCT); criação da Universidade de Campinas, UNICAMP (1967), para promover em São Paulo a pesquisa básica e o desenvolvimento tecnológico, com o retorno de alguns pesquisadores do estrangeiro, principalmente dos EUA (Brisolla e Pinto, 1991). Em 1968, fez-se a Reforma Universitária, com a pós-graduação já funcionando desde 1964, com nova meta de ensino superior. Cinco anos depois, foi aprovado o $1^{\circ}$ Plano Básico de Desenvolvimento Científico e Tecnológico (PBDCT), ano que se iniciou, na Faculdade de Economia e Administração da USP, o Programa de Administração em Ciências e Tecnologia (PACTo) conduzido por excelentes professores e pesquisadores da Universidade de São Paulo.

No final dos anos 70, cria-se a Secretaria Especial de Informática (SEI) para formular a política Nacional do Setor, objetivando introduzir o País na trilha de modernização em que se encontravam os países desenvolvidos. "Trata-se, indiscutivelmente, de um pensamento brasileiro para o crescimento de um Estado periférico, adaptado, à realidade nacional, o modelo vigente dos países capitalistas avançados"(Becker e Egler, 1988). Até o nos 70, o Brasil conseguira reunir os elementos de um "complexo nacional de Desenvolvimento Científico-Tecnológico", Saliente-se que, na entrada dos anos 80, o Brasil tinha consolidado seu parque industrial dentro dos parâmetros da $2^{\mathrm{a}}$ Revolução Industrial, a partir do apoio decidido do Estado desde os anos 30 (Canp, 1993).

No que se refere à CeT, a década de 1970 foi salutar: maior autonomia do CNPq, criação da Financiadora de Estudos e Projetos - FINEP -, e de "uma moderna rede de pesquisa federal (CEPES, EMBRAPA etc) e estadual (TECPAR, NUTEC etc), bem como novos cursos universitários de engenharia, "conforme referência da Comissão Parlamentar Mista de Inquérito em 1991 (p. 20). Somente, ainda, o surgimento do Centro de Pesquisa e Desenvolvimento da Telebrás, do Instituto Nacional de Pesquisas Espaciais e do Centro Tecnológico para a Informática.

Ante à instabilidade macroeconômica do sistema capitalista, com retratação dos investimentos internacionais, nos anos 80, os recursos tornam-se rarefeitos e o sistema de $\mathrm{C} \mathrm{e}$ $\mathrm{T}$ começa a decair. Entre 1984-86 a economia nacional deu sinal de recuperação, possibilitando maiores recursos às linhas de fomento a CeT.

Para garantir sua continuidade, cria-se, em 1985, o Ministério de Ciência e Tecnologia (que se transformaria, em pouco tempo, em Secretaria de CeT (PADCT), como primeira experiência nacional de associar a ação governamental com o mercado, especialmente nas áreas de tecnologia "de ponta". (Suzigan, 1992: 98).

\section{b) O embrião dos Pólos Tecnológicos}

Com o avanço tecnológico e a formação de um mundo mais competitivo nos anos 80 , o governo brasileiro expressa grande esforço para tentar seguir o ritmo de seus parceiros mais ricos, embora de forma limitada e localizada.

Essas iniciativas procuravam estimular a formação de alguns centros dinâmicos e propiciar aos poucos centros de excelência existentes 19 como Campinas, São José dos Campos, no Estado de São Paulo) uma organização mais formal de seus agentes potenciais, voltando-os à capacitação competitiva mundial, quer naqueles pólos de interesse industrialmilitar, que nos pólos envolvidos 
com as indústrias do mercado civil. Desse modo, procura-se através do $\mathrm{CNPq}$, dar apoio mais sistemático aos centros de pesquisa e ensino públicos, a fim de se capacitarem em transferir inovações tecnológicas ao setor produtivo, como sói ocorrer com alguns institutos de pesquisa (Perilo, 1987).

O primeiro mecanismo para promover a vinculação pesquisa-produção foi o do Núcleo de Inovação Tecnológico - NIT, no início dos anos 80, formado por pequeno grupo de 2 a 5 pessoas no âmbito de Universidade ou Instituto de Pesquisa. O NIT teria a responsabilidade primordial de coordenar e propiciar meios para a identificação, difusão e transferência de inovações. Seriam grupos criados em instituições em vários Estados do País, descentralizando ações do CNPq para efeito de valorização das inovações tecnológicas.

Das instituições beneficiadas, nem todas situavam-se em ambiente dinâmico no que se refere à pesquisa e à vida empresarial. Técnicos do CNPq (Medeiros, Stal e Souza Neto, 1987) constataram uma série de desvios na condução dos NITs, tornado precários a interação com o setor produtivo e o prestígio com o corpo técnico. Surgiram esses analistas que o programa dos NITs deveria ser retomado com "a incorporação de experiências recentes, como os "aglomerados Tecnológicos ou Parques Tecnológicos", onde se constata uma maior interação entre o setor de pesquisa e o setor de produção e o surgimento de empresas que viabilizam tecnologias geradas pelas instituições de pesquisa do país". Em seguida adiantam: "pode-se utilizar o NIT como embrião do Parque Tecnológico".

\section{c) Os Pólos Tecnológicos Brasileiros}

A decisão de fomentar os Parques Tecnológicos, como um outro mecanismo de indução ao desenvolvimento, foi implantada também pelo CNPq nos anos $84 / 85$, inicialmente com a assinatura de convênios com instituições em Joinville, São Carlos, Campina Grande, Manaus e Santa Maria (RS). Com essa ação, o governo procurava dar sua contribuição para o possível "salto tecnológico".

Outros centros urbanos, posteriormente, tornaram-se pólos tecnológicos: Campinas, Curitiba, Florianópolis, Santa Rita do Sapucaí, Petrópolis, Porto Alegre, São José dos Campos, Rio de Janeiro, (com pólos Bio-Rio e Riotec) e Vitória.

Em levantamento patrocinado pelo CNPq e ASSOCIAÇÃO Nacional das Entidades Promotoras de Tecnologias Avançadas (ANPROTEC), Medeiros e outro (1991) relacionaram os pólos de Joinville e Santa Maria apresentando-os em reavaliação, enquanto Vitória, Porto Alegre e Petrópolis apresentam-se como pólos em implantação.

Acompanhando a evolução dos Pólos Tecnológicos no Brasil, verifica-se, em publicação patrocinada pelo CNPq e outros orgãos (Medeiros e outros, 1992)), que não constam da relação dos pólos científico-tecnológicos: os de Joinville, Manaus, Petrópolis e Santa Maria, adicionando-se os de Brasília, Recife e Fortaleza apenas com instalação de incubadoras empresariais tecnológicas.

Desse modo, dez pólos tecnológicos têm vida ativa, na entrada da década de 1990: 1 no interior do Nordeste, 3 na região Sul, e 6 no Sudeste - 3 no interior de São Paulo, 2 na cidade do Rio de Janeiro e 1 em Minas Gerias - (mapa 19).

Por certo esse resultado no Brasil reflete o que disse Jacques Marcovitch (1987: 69): “os parques tecnológicos já constituídos basearam-se em esforços conseqüentes e de longo prazo e não apenas em sonhos e discursos". É o que tentaremos mostra em seguida: 


\section{Mapa 19}

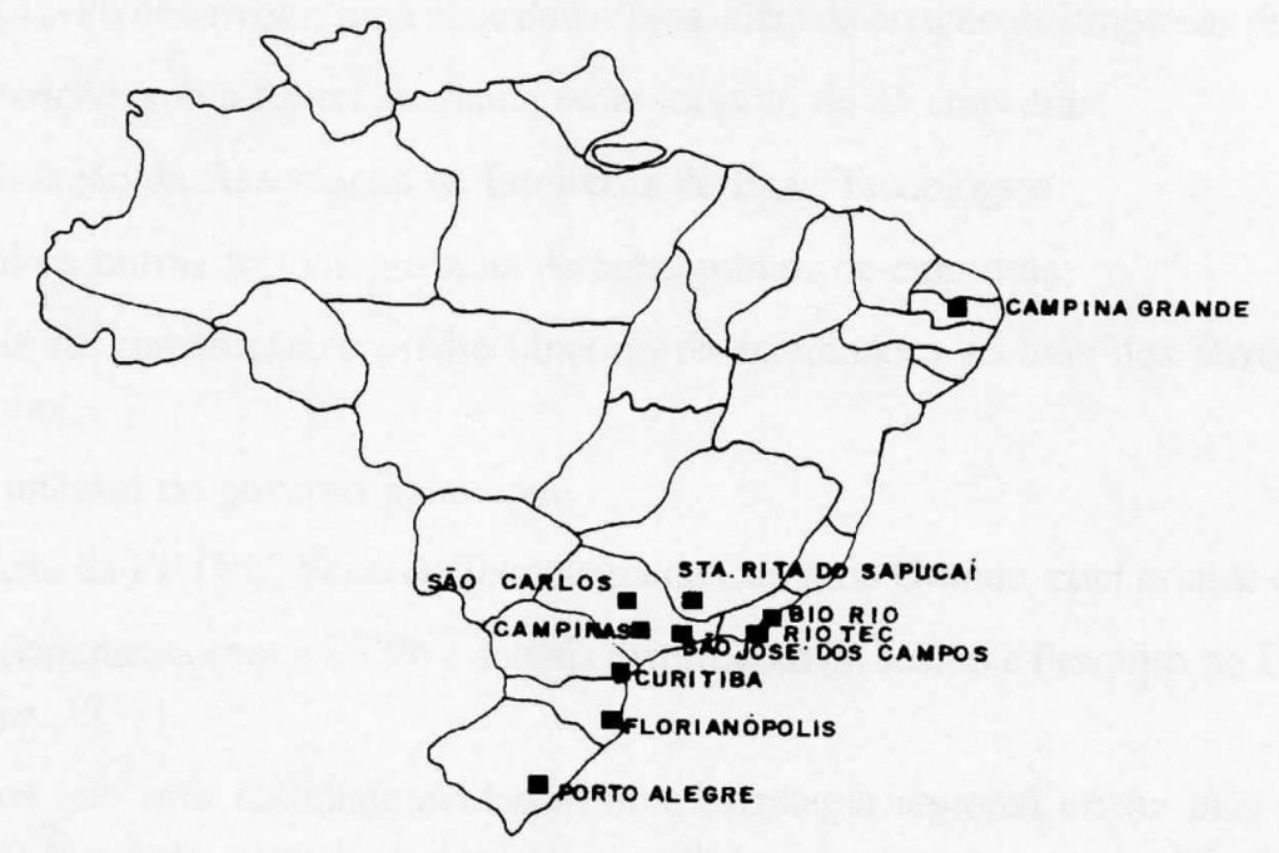

I - Parque Tecnológico da Paraíba (Paq Tc-Pb).

Pode-se afirmar que este seja um pólo assentado, graças ao emprenho contínuo dos governos local e estadual, dos empresários, da UFPb e dos órgãos federais, como o CNPq e a FINEP.

Partícipe dos programas do CNPq desde a formação dos NITs, o Paq Tc-Pb tem sua expressão em Campina Grande, importante centro regional de rede urbana do Recife, no interior agrestino da Paraíba, onde funciona um campus da Universidade Federal - a $3^{\mathrm{a}}$ do País - e uma Escola Técnica de Eletro-eletrônica, além de uma Universidade Estadual.

O empresariado de Campina Grande tem tido relevante desempenho no desenvolvimento industrial do Município, chegando a ultrapassar a Capital, encabeçado pelos setores mineiros não-metálicos, material elétrico-eletrônico e metalúrgico, inclusive com ligações com o Sudeste do País.

Além das escolas técnicas de nível médio, a UFPb revela-se como núcleo propulsor do Pólo Tecnológico. Teve importância, inicialmente, a ATECEL (Associação TécnicoCientífica Ernesto Luís de Oliveira), criada em 1967 pelos professores de engenharia, no intuito de prestar serviços de engenharia, instalando, em 1970, o primeiro computador em Universidade do Norte-Nordeste. "Também o Instituto de Tecnologia de Eletro-Eletrônica, uma sociedade sem fins lucrativos, criado por convênio entre a UFPb, o governo do Estado e o CNPq, funciona como uma ponte entre a Universidade e a sociedade" (Medeiros, 1992-b; 73).

Em Engenharia elétrica-eletrônica, em Ciências Exatas e em Biologia, a UFPb se situou entre as 
cinco melhores instituições de Ensino (IEs) federais em 1990: UFRJ, UFSC, UFPr e UFScar, no que concerne à formação de recursos humanos e pós-graduação.

Em termo de captação de recursos de CNPq, foi superada apenas pela UFRJ, UFRS, UFM e UNB, embora seja a primeira do ranking na engenharia elétrica, conforme dados do CNPq e FINEP (Apub Araújo, 1991). Ademias, Campina Grande mantém o único curso de doutorado de Engenharia Elétrica e Informática da região Nordeste. Nesse ambiente técnicocientífico edificado ao longo de décadas, o Paq Tc-Pb desenvolve uma série de eventos, além da criação de Empresas de base tecnológica:

a) Manutenção, sob a forma incubada ou associada, de 25 empresas;

b) consolidação da Associação de Empresas de Base Tecnológica;

c) estímulo a outras formas privadas de condomínios de empresas;

d) em fase de construção, o prédio (âncora) da Incubadora ao lado dos terrenos destinados às empresas;

e) apoio do governo municipal;

f) realização da FETEC, feira de Tecnologia de Campina Grande, com grande destaque regional;

g) ação cooperativa com a UFPb e demais instituições de ensino e Pesquisa no Estado da Paraíba. (Araújo, 1991)

Parece-se que essa realidade evidencia uma estratégia regional eficaz proposta por Almeida (1985: 171): “O Nordeste, através de suas Universidades, deve pensar sua realidade e seu projeto e o Brasil como um todo, para, a um tempo, participar das decisões centrais e otimizar a posição do Nordeste nos modelos nacionais". É nesse sentido que se consolida o Pólo Tecnológico de Campina Grande.

II - Fundação Bio-Rio ou PÓLO de BIOTECNOLOGIA do Rio de Janeiro. Metrópole nacional, historicamente participante da formação da cultura brasileira e dotada de forte arcabouço tecnológico e científico: Universidades, centros de pesquisa, sede de empresas públicas e privadas com conceituados departamentos de $\mathrm{P}$ x D, institutos científicos de tradição, o Rio de Janeiro é parte intrínseca do cérebro nacional.

Apesar desse conjunto de condições, esta metrópole não ficou imune à avassaladora crise que domina todo o sistema capitalista e, com forte dosagem, o Brasil. No caso do Rio de Janeiro isso já se dá na área industrial desde a metade dos anos 70 .

Muitas pessoas, empresas, instituiçoões variadas procuram retornar as dimensões do processo de construção do novo mundo. O Rio de Janeiro se insere no esforço nacional de edificação dos pólos tecnológicos, nos moldes internacionais.

A idéia nasceu da articulação, em 1983, entre a Prefeitura Municipal do Rio de Janeiro (PMRJ), o Ministério de Ciência e Tecnologia, (MCT), a FIOCRUZ e a Associação Brasileira da Empresa de Biotecnologia (ABRABI), com a assinatura de um protocolo de intenções para a criação do Pólo de Biotecnologia do Rio de Janeiro, ao qual integram, no ano seguinte, o governo estadual e o BNDES. Marcava-se como objetivos: "Promover o desenvolvimento técnico-científico e as aplicações produtivas das biotecnologias através da colaboração mútua entre o setor de pesquisa (universidade e institutos de pesquisa), o setor produtivo (empresas públicas e privada), o governo e os investidores 
privados". Para a implantação e a administração do pólo constitui-se a Fundação BIO-RIO, de direito privado.

Entre os parceiros encontram-se, também, a Fundação Banco do Brasil, a Associação das PMEs e Associação Comercial do Rio de Janeiro. Enfrentando as dificuldades inerentes ao próprio projeto e à crise atual, a Fundação conseguiu o suporte territorial do pólo (20,7 há.), urbanizado pela Prefeitura Municipal, no próprio Campus da UFRJ, onde se instalam a Universidade central como os laboratórios, a incubadora e algumas empresas. Por situar-se no próprio Campus Universitário, o BIO-RIO é o primeiro Parque Tecnológico brasileiro, diferenciando-se, portanto, dos demais então existentes, o que lhe favoreceu melhores contatos intensos com grupos de pesquisa da UFRJ, da Universidade Federal Rural do Rio de Janeiro e da FIOCRUZ. Os convênios de P x D, serviço, aluguel das empresas incubadoras resultam uma receita de US\$35.000 mensais que lhe cobre os custos.

A literatura tem registrado este Pólo Biotecnológico como um dos que apresenta capacidade operacional, habilitado para um avanço significativo na década atual.

\section{III - RIOTEC S.A}

O processo de desindustrialização do Rio de Janeiro desperto, na década de 80, um grupo de industriais ligados à tecnologia "de ponta" a constituir um sistema de condomínio empresarial, com o propósito de executar o "estabelecimento de serviços cooperativos que apoiem o desenvolvimento tecnológico de seus acionistas (para melhorar a base tecnológica do setor industrial), atração e fixação de empresas do Pólo tecnológico (implantação de parque de fornecedores, atração de empresas de alta tecnologia de outros Estados e criação de novas empresas de alta tecnologia, a partir de pesquisas de Universidade e Institutos do Rio de Janeiro) e a promoção do Pólo Tecnológico de Jacarepaguá como centro nacional de excelência nas área de tecnologia de ponta"(Pereira e outros, 1987). Procura-se, assim, montar um pólo de reconversão, utilizando-se de uma parte da capacidade local.

Para isso, no início de 1986 foi firmado um protocolo entre os governos municipal e estadual e empresários, de que resultou a criação da sociedade anônima RIOTEC para administrar o Pólo de Alta Tecnologia de Jacarepaguá.

A preferência por essa área da Cidade deve-se à proximidade de importantes indústrias ligada à eletrônica, já em funcionamento (COBRA, CONPART, MODDATA, RACIMEC e $\mathrm{ABC}$ ) e por, conseguinte, a presença de mão-de-obra especializada, além de terreno (60 há.) reservado pelo poder público para esse investimento.

Ademais, Jacarepaguá, na zona sudoeste da cidade do Rio de Janeiro, distanciava-se do alto adensamento de fábricas poluidoras e de grande porte e do aglomerado de operários que ocupavam extensas áreas de construção caótica das zonas Norte e Leste. Aliás, no inicio dos anos 70, já se previa para o ano 2000 que o "caminho do ouro, isto é, o Estado da Guanabara, de então, se desenvolveria de leste para oeste..."(Brasil:Guanabara, 1971: 176).

Situando-se nesse quadrante da ex-Guanabara, a RIOTEC obedecia um dos preceitos comuns aos pólos de alta tecnologia: ocupar espaços mais agradáveis para o trabalho e o lazer, de beleza cênica e sem poluição, não muito distante dos centro de pesquisa e $\mathrm{d}$ ensino. Localizada no Parque, a empresa gozará de isenções e subsídios.

Essas condições poderiam oferecer às novas empresas facilidades, tais como: uso comum de informações, laboratórios de $\mathrm{P}$ x $\mathrm{D}$, enquadramento urbano, infra-estruturas e outros benefícios no 
sentido de "reduzir investimento e de ganho de escala". O que diferencia esse pólo dos demais Brasil é que ele se centra mais nas relações inter-empresariais. Depois de mais de um ano de vida do RIOTEC, o convívio empresa e universidade ainda estava ao nível das intenções, conforme relata o jornalista Mário Fonseca, em meado de 1987: "A partir do próximo ano (a RIOTEC) realizará pesquisas dentro das Universidades que atenderão grupos de empresas e não mais empresas isoladas, como constantemente acontece no país". Anteriormente, contudo, Reis (1986) registrara:"no empreendimento, associaram-se a prefeitura carioca, o governo estadual e mais as instituições de ensino e pesquisa (COPPE e NIT da UFRJ), associações empresariais e empresas do setor de informática que foram outros (1992-b: 147), ao compararem a RIOTEC à experiência de Sophia Antipolis, em França: "as instituições de ensino seriam atraídas para Jacarepaguá num segundo momento, como ocorreu em outros países. Pensou-se em trazer para o local o Instituto Nacional de Tecnologia (INT), o Laboratório Nacional de Computação Científica (LNCC), o Centro Brasileiro de Pesquisa Físicas (CBPF) e departamentos de outras instituições e universidade do Rio de Janeiro". Por esses testemunhos, o Pólo de Jacarepaguá se nos apresenta como um distrito industrial de alta tecnologia, dentro do que se referia Davidovich (1977:556): "ganham também expressão as perspectivas de recuperação industrial da ex-Guanabara no momento em que se concretizou a fusão com o Estado do Rio e em que já se institui a política de distritos industriais dentro do território carioca".

\section{IV - Pólo Tecnológico de Santa Rita de Sapucaí (SRS)}

Nas coordenadas $22^{\circ} 15^{\prime} \mathrm{S}$ e $45^{\circ} 42^{\prime} \mathrm{O}$ está a pequena cidade de Santa Rita de Sapucaí (40.000 hab.) na Serra da Mantiqueira, sul de Minas Gerais, mais próximo das cidades de São Paulo $(230 \mathrm{~km})$ e Rio de Janeiro $(350 \mathrm{~km})$ do que de Belo Horizonte $(400 \mathrm{~km})$.

De São Paulo, pelo Br 382 (Rodovia Fernão Dias) e por um trecho de $20 \mathrm{~km}$ da Br 459 chega-se facilmente a Santa Rita de Sapucaí.

O mercado metropolitano de São Paulo, por proximidade, tem exercido forte pressão sobre o sul de Minas Gerais, tanto na demanda de produtos agrícolas e do potencial turístico (estações hidro-minerais), como na industrialização de algumas cidades; Itajubá, Pouso Alegre e SRS, entre outras.

SRS teve sua economia marcada pelo café e gado leiteiro, tipificando assim sua posição entre os dois Estados cuja história republicana pela batizada política "café com leite".

Esses produtos contribuíram para fortalecer o poder local e capitalizar outras atividades, como o comércio e a pequena indústria. Daí se viabilizaram condições políticas para a consecução de equipamentos sociais e urbanos, benefícios dos governos estadual e federal, e, expressar-se nacional e internacionalmente como pólo tecnológico ou vale da Eletrônica.

Desde o final dos anos 50, vários eventos de caráter cultural se adicionam para efetivação do Vale da Eletrônica dos anos 80. Através da influência da rica Sra. Luiza Moreira, conhecida como Sinhá Moreira, (fillha do criador do Banco Nacional), junto ao Presidente Juscelino Kubitschek, foi instalada a Escola Técnica de Eletrônica em 1959, sob a administração dos Jesuítas; o capital privado criou, em 1965, o Instituto Nacional de Telecomunicação e Eletrônica - INATEL. Desde 1972, funciona na cidade a Faculdade de Administração de Empresa e Informática. Além dessa intra-estrtura de 
formação e pesquisa em SRS, em Itajubá funciona uma Escola Federal de Engenharia.

Esse conjunto de escolas dedicadas às áreas de eletrônica, de telecomunicação e informática têm formado um ambiente de cultura tecnológica e induzido o surgimento de empresas pautadas em produzir instrumentos moderno: antenas parabólicas, terminais de vídeos, receptores de satélites, PABX eletrônico modular, retransmissores de TV etc.

Na metade dos anos 80, com o forte empenho da Prefeitura, da Associação Industrial e das escolas, foi criado o Pólo Tecnológico, dando-se continuidade a um maior impulso à criação de empresas, muitas de iniciativa de ex-alunos do INATEL. No início da década de 1990, são mais de sessenta pequenas empresas, oferecendo emprego a aproximadamente 1.800 pessoas e atingindo um faturamento anual acima de US\$ 80 milhões (Medeiros e outros, 1992b).

Com a realização de Feiras Tecnológicas e marketing, as empresas têm ampliado seu mercado para o exterior.

As informações contidas na literatura especializada nos possibilitam uma explicação dos fatos responsáveis pelo sucesso desse pólo: em primeiro lugar, a formação do ambiente inovador, a partir dos anos 60, com a iniciativa da "Sinhá Moreira"e o empreendimento privado do INATEL e a instalação da primeira indústria em 1974, a Líder, (Medeiros e outros, 1992), disseminando assim uma cultura técnica; segundo, além da formação de mão-de-obra especializada, a aquiescência no uso dos equipamentos e dos laboratórios das ETE e INATEL - pelas empresas nascentes, em forma de aluguel, empréstimo ou convênio, (Patricio, 1985) representava forte incentivo, não só às iniciativas locais, como também à atração de empresas de outras localidades, especialmente de São Paulo; terceiro, subsídios, incentivos e ajudas para o assentamento das empresas, além da informalidade do poder público local na instalação de fábricas ligadas ás áreas da informática, eletrônica e telecomunicação; quarto, a proximidade dos mercados das três maiores metrópoles do País, mui especialmente do de São Paulo, o que tem propiciado intensos fluxos de negócios entre a pequena cidade e as grandes aglomerações. Em 1977, estudo da hierarquia urbana do Sudeste brasileiro (Lima e Corrêa) situava SRS subordinada a Pouso Alegre, de nível $3^{\text {a }}$, que lhe dava suporte para relacionar-se com as maiores cidades; quinto, à consideração do estudo de Becker e Egler (1988: 19), "o Vale da Eletrônica representa uma interface entre a eletrônica e a mecânica, para a produção de servo-mecanismo 'inteligentes', como sensores especiais, necessários à indústria de ata tecnologia e bélica". Esse fator locacional insere SRS/Itajubá nas "paisagens tecnógenas"eu englobam o Vale do Paraíba e o litoral entre São Paulo e Rio de Janeiro e ramificações em direção a Campinas e à $\mathrm{Br} 459$; sexto, semelhante a quase todos os pólos tecnológicos , o Vale Eletrônico teve seu desenvolvimento apoiado pelos recursos públicos, estaduais e federia: na fase embrionária, com a ETE; através da forte participação da Prefeitura em conceder indústrias (Patrício. 1985). De modo indireto, "existiram auxílios das grandes estatais do setor de telecomunicações, através de mecanismo de contratos informais. Isto se deu, visto que muitas pessoas formadas no INATEL ocupam hoje importantes cargos técnicos e políticos em uma série de empresas..." (Nascimento e outros, 1990).

Além disso, o INATEL tem estreita "relações com orgãos do governo", além de as empresas manterem contratos formais com setores militares. 


\section{V - Pólo Tecnológico de São José dos Campos (SJC)}

São José dos Campos (SJC) situa-se a $90 \mathrm{~km}$ da Capital Paulista, à MARGEM DA Vila Dutra que liga as duas grandes metrópoles do País. A cidade com quase meio milhão de habitantes e mais de seiscentos estabelecimentos fabris, entre os quais algumas multinacionais (Ericsson, Johnson \& Johnson, General Motors, entre outras) e duas dezenas de indústrias nacionais de alta tecnologia.

A determinação de SJC como sede da Região Administrativa do Vale do Paraíba em 1970 indica seu nível de centro regional num dos eixos complementares, em termos industriais, à região metropolitana de São Paulo (Souza, 1970).

Esse patamar econômico foi atingido em face do processo de industrialização desde os anos 20 e consubstanciado com a formação do complexo tecnológico-industrial-aeroespacial nos anos 60-70 (Costa, 1982), originado do Centro Técnico Aeroespacial - CTA, antes de 1971 (chamado de Centro Técnico de Aeronáutica). Na década de 80, SJC se manteve como pólo criador de indústrias de alta tecnologia, paralelamente À queda dos recursos disponíveis para a pesquisa nas Universidades.

Implantado em SJC, em ampla área territorial e próximo ao mais importante complexo industrial do País, o CTA objetivava formar mão-de-obra altamente qualificada no setor aeronáutico, conduzir PxD e criar uma forte articulação de $\mathrm{C}$ e T. Para atingir esses objetivos, no seu interior criaram-se cinco institutos: nos anos 50, o Instituto Tecnológico da Aeronáutica (IAE), o de Fomento e Coordenação Industrial (IFI) e o de Estudos Avançados (IEA).

A base tecnológica de SJC se fortalecera mais ainda com o surgimento, em 1961, do Instituto de Pesquisa Espacial (INPE), de caráter civil, dedicado às ciências espaciais e atmosféricas em aplicações espaciais (meteorológica e sensoriamento remoto) e engenharias e tecnologias espaciais, tanto na área do ensino de pós-graduação como da pesquisa, ocupado 1.400 funcionários, sendo parte do staff inicial oriundo do CTA.

Além do CTA e do INPE, a cidade dispõe da Universidade do Vale do Paraíba (UNIVAP). Escola de Engenharia Industrial e duas escolas técnicas de nível médio.

Com esse arcabouço de instituições de formação e pesquisa, detentoras de base tecnológica moderno, tendo o CTA como coluna vertebral, SJC é galgada a centro das prioridades da Política de Segurança Nacional, a partir da segunda metade dos anos 60, com o novo quadro político implantado em 64 no Brasil. Com esse norteamento, intensifica-se a formação de empresas com o apoio técnico direto e permanente de IFI e do IPD e sob os auspícios do governo central manietado pelos militares.

Entre as quinze principais empresas do complexo industrial-militar de SJS, relacionados por Nascimento e Perilo (1991), somente quatro surgiram antes de 1965; as três maiores EMBRAER, ENGESA e TECNASA - se dedicam à produção de material bélico, em grande parte, para as Forças Armadas do Brasil e do exterior. (Dagnino, 1983).

SJC se constitui, então, no núcleo técnico-científico informacional de um conjunto de pontos do espaço nacional, cujos fluxos tecem a rede de produção armamentista brasileira no corredor metropolitano entre SP e RJ. Esse pontos são identificados em MG (com o Vale da Eletrônica e a empresa Manesmann), em Porto Alegre (Aeromot), na cidade de São Paulo (Metal Leve e Whinner), no Rio de Janeiro (Motortec), em diferentes cidades do Vale da Paraíba (Jacareí, Lorena, Piquete e Cruzeiro) que se associaram no Projeto Brasil Potência. (Beker e Egler, 1988; Costa, 1982). 
Releva observar que essa formação de rede associa-se ao caráter nacionalista assumido pelo complexo industrial-militar, originando uma "horizontalização de sua produção", o que foi evidenciado por Medeiros e Perilo (1989): "essa horizontalização que vem acontecendo nas empresas maiores, associada a uma constante preocupação com a nacionalização de fornecedores, tem favorecido a implantação de novas empresas na cidade".

Por sua vez, em contextura local, a horizontalidade dá origem a um processo de spin-off, cujos mecanismos foram relacionados pelos autores últimos citados: 1. "pesquisadores oriundos do setor de pesquisa local, (Avibrás, Tecnasa, Composite, etc), 2. empresa criada a partir do projeto desenvolvido em institutos de pesquisa (Embraer e $\mathrm{ABC}$ ); 3. empresas atraídas pela cidade (Engesa, ABC, Amplimatic); 4. empresas criadas por consórcio de empresas existentes (Órbita); 5. empresas criadas por fundação associada a instituto de pesquisa (Engespaço); 6. empresas criam subsidiárias (Avibras, Embraer, etc)".

De 17 fatores característicos da implantação e desenvolvimento de Pólos tecnológicos, relacionados por Nascimento e Perilo (1991) com base na literatura mundial especializada, 14 estão presente em SJC, sendo 5 fortemente característicos do local, 8 relevantes no contexto local e somente 1 não é significativo no contexto de SJC.

Embora os dados configurem com clareza a presença de um Pólo tecnológico em SJC, no entanto os Autores, por último citados, apresentam oito "peculiaridades que o diferenciam do que se poderia chamar de um pólo tecnológico típico".

\section{VI - Campinas}

Para este item, além de algumas indicações no correr do texto, seguimos de perto dados de três trabalhos: Medeiros e outros (1992), Jóia (1992) e Rius (1989).

Numa altitude de $854 \mathrm{~m}$, a cidade de Campinas, onde moram mais de um milhão de pessoas, situa-se a $100 \mathrm{~km}$ no noroeste da capital de São Paulo, com a qual se liga por duas autoestradas - (Anhanquera e Bandeirantes) ferrovia e circuito aéreo.

Marcada pela vida agrícola - café, algodão e cana -, já no final do século XIX recebia as indústrias metal-mecânicas que atendiam a demanda das indústrias têxtil e alimentar e do sistema ferroviário e se infiltrara pelo interior do Estado a serviço do café. A rica atividade do campo no século XIX fora responsável pela instalação do Instituto Agronômico, signo pioneiro da atmosfera técnico-científica que envolveria Campinas, na segunda metade do século XX. Logo ao término da $2^{\text {a }}$ Grande Guerra, Campina é enriquecida com a Pontifícia Universidade Católica - PUC.

Entroncamento das linhas rodo-ferroviárias, que se estendem para além fronteiras estaduais e a proximidade de São Paulo deram a Campinas a condição de se tornar um núcleo de atração de várias indústrias, inclusive multinacionais espalhadas ao longo da Via Anhanguera e em cidades próximas (Valinho, Sumaré etc.) se afeiçoando como "principal eixo da industrialização paulista" (Souza, 1976), com ampliação e maior complexidade do mercado de trabalho.

No início dos anos 60 é criada a Universidade de Campinas, que se instala em 1967, estruturada em Institutos e Faculdades com forte empenho na área de pesquisa e pósgraduação. Mantém dois colégios técnicos (um em Campinas e outro em Limeira) e um Centro de Tecnologia que atua como interface nas relações com o setor empresarial. Desenvolve cinco programas, como centenas de Projetos nas áreas da informática, biotecnologia, química fina, energia e novos materiais (mapa 20). 


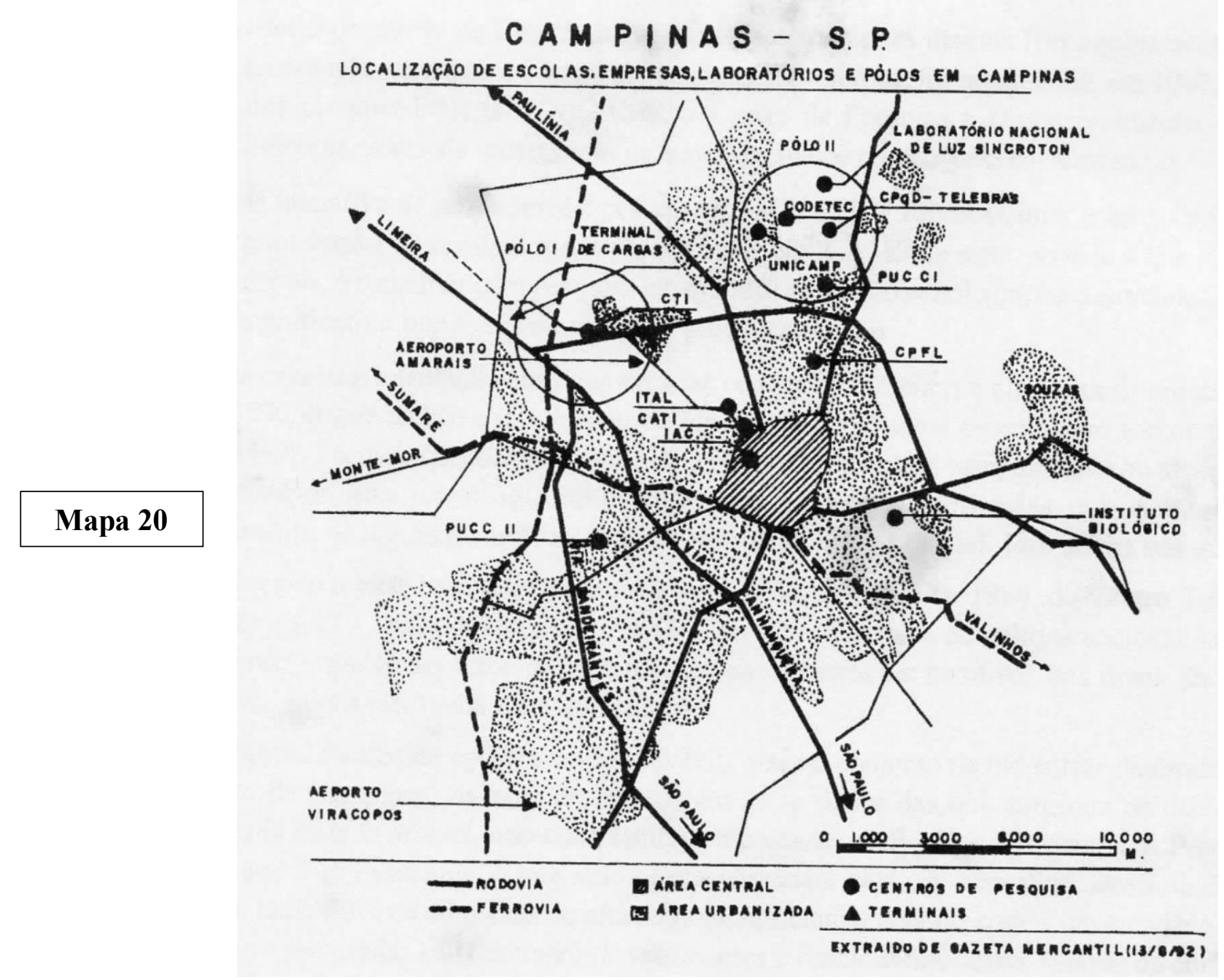

A região campineira inicia a década de 1970 com um quadro econômico, demográfico, cultural e de infra-estrutura que se definia como um "prolongamento da área metropolitana" e que tornaria Campinas a sede de Região Administrativa no final de 1970 (Souza, 1976) e elegeria sua malha urbana para a política de descentralização industrial de São Paulo.

Ante o nível acadêmico elevado com o funcionamento da UNICAMP, que agregava qualificados pesquisadores recém-chegados de universidades de fama internacional, nessa porção do território paulista, a década de 70 estaria fadada a ser de fértil desenvolvimento do ambiente técnico-científico, pois nela se conjugariam vários eventos favoráveis à formação do Pólo Tecnológico de Campinas:

$1^{\circ}$ ) a política estadual de descentralização industrial, com incentivos fiscais, financeiros, reordenamento territorial etc;

$2^{\circ}$ ) decisão do governo federal em modernizar científica e tecnologicamente o País, dentro de um espírito nacionalista, portanto investindo pesadamente na formação de recursos humanos e na montagem de laboratórios, em equipamentos das Universidades e Institutos de Pesquisa; com essa busca de autonomia tecnológica, o governo estabelece uma série de programas estratégicos ligados a vários setores de ponta, com apoio de CNPq, utilizando centros de excelência, ao nível da UNICAMP;

$3^{\circ}$ ) adicionam-se, às já existentes, instalações de outras multinacionais na região: Hewlett Packard em Campinas, IBM em Sumaré; 
$4^{\circ}$ ) com o propósito de formar uma base tecnológica para desenvolver equipamentos, absorver tecnologia estrangeira interligar pesquisa à produção, foi implantada, em 1976, com auxílio dos pesquisadores da UNICAMP, o Centro de Pesquisa e Desenvolvimento -CPqD- da Telebrás, fonte de emergência de Telecomunicações, em Campinas;

$5^{\circ}$ ) de iniciativa de professores e pesquisadores, em 1977 forma-se uma pesquisa CODETEC - para vender os resultados das pesquisas da UNICAMP ao setor privado e que passaria, anos depois, a trabalhar com pesquisa em química fina e biotecnologia; essa entidade desempenhou significativo papel na formação do pólo tecnológico.

Toda essa motivação nas duas décadas conduzia Campinas a uma taxa de crescimento anual acima de 5\%, o que enfatizaria a crença de alguns atores locais e externos em tornar consistente o manifesto Pólo Técnico-Científico, tanto com a absorção de outros equipamentos ou atração e criação de empresas de alta tecnologia resultantes das pesquisas efetivadas, como também com o estabelecimento de algumas medidas de nível institucional e territorial. Isso se fez nos anos 80 .

Reforça-se a base tecnológica com a inauguração, em maio de 1984, do Centro Tecnológico de Informática - CTI -, para desenvolver P x D, dentro dos objetivos da política nacional então vigente, dando grande impulso ao setor da informática, com resultados positivos nas áreas da comunicação, computação, micro-eletrônica e instrumentação.

Conforme estatística colhida em Jóia (1992), para o conjunto de indústrias dinâmicas e de base tecnológica de Campinas, os anos 80 oferecem 21, o dobro das que surgiram na década anterior. Nessa década mais favorável, nasceram também 6 unidades de P x D e 2 Institutos de Pesquisa que se somaram aos 3 já existentes, o que veio impregnar, mais ainda, a atmosfera inovante da região de Campinas, onde $80 \%$ de empresas de alta tecnologia mantêm conto com a universidade e Institutos de pesquisa e 44\% delas são derivadas de professores e funcionários desses centros de conhecimentos, conforme pesquisa de CIATEC junto a 44 empresas (Medeiros e outros, 1992b).

As políticas de reserva de mercado e incentivos do governo federal nas áreas de informática e telecomunicações estimularam essas ações empresariais e de P x D, fazendo ressaltar os esforços que desenvolviam, desde os anos 60 , conceituados pesquisadores da área de Física na UNICAMP, provindos de centros variados do Brasil e do mundo (Brisolla e Pinto, 1991).

Com o surgimento do Ministério de Ciências e Tecnologia em 1985, reforça-se mais o apoio mito presente do $\mathrm{CNPq}$, não só no próprio Projeto de consolidação do Parque Tecnológico, como também na implantação do Laboratório Nacional de Luz Sincrotom (LNLS).

Em meado da década de 1980 foi decisiva a ação da Companhia de Desenvolvimento do Pólo de Alta Tecnologia - CIATEC, (com 70\% da ações da Prefeitura de Campinas e 30\% da UNICAMP), na interação dos agentes de pesquisa x produção. Disso resultam transferência vertical de tecnologia e um conseqüente e efetivo processo de spin-off. Daí por que são várias as novas empresa de alta tecnologia, nos anos 80, nas áreas de micro-eletrônica e de telecomunicação: Elebra, Hober, SID, Icatel, Enetele.

Também decorre do trabalho da CIATEC a delimitação e urbanização de duas grandes áreas que serão os Pólos I e II, à semelhança de Parques Tecnológicos, com 68 ha. E 700 ha. Respectivamente, "levada à discussão como parte do Plano Diretor da cidade" (Medeiros e outros, 1992b;87). Nesse projeto de expansão territorial do Pólo Tecnológico também foram envolvidos a FEPASA e a Companhia Paulista de Luz e Força (CPFL). 
Essa participação do poder local, atraindo também o capital imobiliário privado, têm tentado proteger as zonas de alta tecnologia, não só os estabelecimentos de pesquisa e produção como também o conjunto de habilitação dos técnicos e pesquisadores. Mesmo assim não tem evitado assentamento da população pobre, como é o caso da favela São Marcos nas proximidades do Pólo. Esse fenômeno é ocorrente também em outras áreas tecnolopolitanas (como já tratamos, no item Sociedade Dual, p. 60-62), criando áreas de segregação urbana, como é o caso do Distrito de Barão Geraldo, $10 \mathrm{~km}$ do centro de Campinas, onde,"além do pessoal da UNICAMP, dos Institutos de Pesquisa e das indústrias de alta tecnologia de Campinas, residem pessoas pertencentes aos quadros qualificados das indústrias locais e regionais. Assim foi criado um ambiente agradável aos trabalhadores de alta tecnologia, com uma paisagem propícia à reflexão, criação e descanso"(Jóia, 1992: 113).

\section{VII - Parque de Alta Tecnologia de São Carlos}

É o terceiro pólo tecnológico do Estado de São Paulo, situado a $230 \mathrm{~km}$ da Capital, onde estão presentes duas Universidades, a USP e a UFSCar.

É uma cidade de porte médio, com aproximadamente 143.000 hab. E elevado nível cultural: mais de 2.000 estudantes de pós-graduação, o dobro na graduação, dois laboratórios da EMBRAPA, um SENAI, SENAC e uma tradição cultural ligada à tecnologia. Além disso, seu parque industrial é composto por indústria do porte da Johann Faber e da Clímax.

Esse Pólo será estudado numa abordagem de detalhamento no capítulo 5, p. 131 e ss.

\section{VIII - Centro de Integração Tecnológica do Paraná - CITPAR}

O processo de formação do Pólo Tecnológico do Paraná foi parecido com o da industrialização do Estado. Este teve dois momentos (Furlanetto, 1990): primeiro, a partir de 1962, através da criação da Companhia de Desenvolvimento do Paraná - CODEPAR -, atualmente Banco de Desenvolvimento do Paraná - BADEP, obteve recursos para a criação da infra-estrutura (malha-rodoviária, rede de telecomunicação, energia elétrica); em seguida, implantada a Cidade Industrial de Curitiba, - CIC, durante os anos 70, o que dá abertura à continuidade e consolidação da política industrial paranaense, com a atração de empresas nacionais e estrangeiras.

Distinguem-se, também, dois momentos no processo de formação do Pólo Tecnológico: a partir de 1984, com as discussões sobre a idéia do Projeto que se seguem com a criação do Centro de Integração Tecnológica - CITPAR, e suas ações preliminares: cadastro das instituições de P x D e infra-estrutura para a formação de recursos humanos. Num segundo momento, entre 1987/88, vêm as ações para instalar empresas e outras medidas de afirmação do desenvolvimento das tecnologias "de ponta" no Estado (Pereira e outros, 1987).

A idéia inicial fora a de criar um pólo de prestação de serviços em informática, o que ficava muito limitada, conforme conclusões dos encontros ocorridos no ano de 1984, entre empresários, políticos, professores, dirigentes de órgãos governamentais, em que se observava que já havia no Paraná núcleos de competência em química fina, em Maringá, e biotecnologia, em Londrina, e, ainda, esforços em andamento para desenvolver mecânica fina, novos materiais, eletro-eletrônica, metal-mecânica e alimentos.

Com o objetivo de transformar o Paraná, a médio e longo prazo, num Estado de Base Tecnológica, criou-se em abril de 1985 o Centro de Integração Tecnológica do Paraná CITPAR. 
Com apoio do governo (municipal, estadual e federal), da Universidade Federal do Paraná - UFPR, do Centro Federal de Educação Tecnológica - CEFET, da Pontifícia Universidade Católica - PUC-PR, do Banco Regional de Desenvolvimento do Extremo Sul - BRDE, da Federação das Indústrias - FIEP, SEBRAE - PR, Instituto de Tecnologia do Paraná TECPAR, e de empresas privadas, o CITPAR desenvolveu as seguintes ações:

- realização do "Cadastro de Entidade e Especialidades que atuam em P x D nas áreas de Biotecnologia, Eletroeletrônica, Informática, Mecânica de Precisão, Microeletrônica, Novos Materiais, Química Fina e Telecomunicações”.

- delineamento do Programa de Desenvolvimento Tecnológico e Industrial de Informática no Paraná, a partir de discussões, seminários e visitas a empresas e instituições públicas privadas de pesquisa e ensino superior. Contando com a participação do CEFET, o Programa transformou-se em curso de pós-graduação.

- criação e implantação de Centro Universidade-Empresa de Informática do Paraná CEIMPAR, "com o objetivo de formar, em curto prazo, mão-de-obra altamente especializada em Informática nas áreas de automação industrial, CAD/CAM, telemática. Do CEIPAR nasce o Projeto de Informática Industrial, PII, com apoio da PUC e da Secretaria de Assuntos Estratégicos da SEI (Secretária Especial de Informática). O PII voltava-se a proporcionar sólido conhecimento em hardware e software, formando profissionais com capacidade de pesquisa e empreendedor, concomitantemente.

- A formação do Grupo de Articulação Tecnológica - GAT - com a participação da Secretaria de Ciência e Tecnologia do Estado, e do BADEP, para estimular o desenvolvimento de tecnologia "de ponta", principalmente na criação de empresas de base tecnológica. Um resultado concreto do GAT foi a implantação da Incubadora Tecnológica de Curitiba (INTEC) com o apoio de TECPAR e do Instituto Euvaldo Lodi (IEL). Na INTEC desenvolvem-se três empresas que já atuam com produtos nos mercados nacional e internacional.

Segundo Medeiro e outros, (1992), “o CITPAR desenvolve intenso intercâmbio com outros países, articulando cooperações científicas, empresariais e tecnológicas", citando-se a França (Universidade de Compiègne, Escola Superior de Mecânica e Micro-mecânica de Besançon), Canadá e Alemanha.

O CITPAR, órgão gestor do Pólo, agrega dezenas de diferentes empresas como associadas, para as quais está montando uma rede estadual de laboratórios de empresas e instituições públicas e privadas do Estado, para facilitar o intercâmbio. Por outro lado, o CITPAR deseja qualificar esses laboratórios pra emitir laudos de qualificação de produtos, num contexto internacional.

\section{IX - Pólo de Alta Tecnologia de Florianópolis}

A capital de Santa Catarina se conjuga com 4 outros pequenos municípios para formar uma aglomeração urbana de 298.047 hab. (161.773 hab. em Florianópolis) na época do surgimento do projeto do Pólo Tecnológico

A base econômica de aglomeração é o setor terciário, mais concentrado em Florianópolis com os serviços, comércio e hotelaria, (muito ligados ao turismo) e o setor público. A comunicação terrestre como o resto do País se faz pelas rodovias BR-101 e BR-262. As atividades industriais e agrícolas são 
inexpressivas. O que realça é a Universidade, dando a pedra de toque da vida da Cidade principal do Estado.

Dada a presença da Universidade Federal, que conta com grupos de pesquisas de excelência em eletrônica e mecânica de precisão, Florianópolis passou a integrar o movimento de formação de pólos tecnológicos, nos anos 80 .

Em 1984, foi criado o Centro Regional de Tecnologia em Informática - CERTI, por iniciativa da UFSC, da SEI (Secretária Especial de Informática) e do Governo do Estado, com o intuito de aproximar o trabalho acadêmico com o setor produtivo, isto é:

- conduzir projetos pioneiros em conjunto com as indústrias, empresas de engenharia e universidades;

- fomentar, junto á UFSC e outras instituições de ensino, programas de desenvolvimento e de formação de recursos humanos na área de automação e controle de processo.

Juntos a esses três membros, outros fazem do CERTI um órgão de prestígio e força: CNPq, Fundação de Ensino de Engenharia - FEESC, Federação das Indústrias, Secretária de Indústria e Comércio do Estado - CIC, Banco de Desenvolvimento do Estado - BADESC, e várias empresas industriais.

Com seis anos de atividades, o CERTI passou a ocupar uma sede própria, com 4 pavimentos, no Campus Universitário, mantendo sua autonomia. Nessas novas instalações, tem ampliado seu raio de ação, indo de prestação de serviços tecnológicos a projetos de transferência de tecnologia e fomento à atividade empresarial em tecnologia "de ponta".

Em 1987, a CERTI criou a Incubadora Empresarial Tecnológica - IET, instalada num espaço de $2.000 \mathrm{~m}^{2}$, próximo ao Campus da UFSC. Das empresas nela estabelecidas, várias convivem em espaços independentes e participam, com sucesso, do mercado.

No prédio da IET, também funciona o Condomínio Industrial em Informática - CII, administrado pela Associação Catarinense de Telemática e Eletrônica - ACATE, que apóia a operação e consolidação de empresas de alta tecnologia, através de instalações físicas dotadas de infra-estrutura e serviços.

Dado o sucesso das iniciativas da CERTI, “o Parque Tecnológico de Florianópolis representa hoje o grande desafio da equipe idealizadora do Pólo de Alta Tecnologia. (Medeiro e outros, 1992-b)

\section{X - Pólo Tecnológico de Porto Alegre}

Porto Alegre, com população em torno de 2 milhões de habitantes, é o principal pólo geoeconômico do Rio Grande do Sul, embora venha perdendo peso relativo na produção industrial desde os anos 70. Em função de seu potencial em ciência e tecnologia, registra-se um grande esforço para entrar no ritmo de crescimento dos paradigmas da atual modernidade (Nascimento e outros, 1990).

Na cidade de Porto Alegre encontram-se institutos de pesquisa, várias escolas técnicas, unidades de ensino superior isoladas e duas Universidades.

A Universidade Federal (UFRGS), criada nos anos 30 e federalizada em 1950, mantém em funcionamento 44 cursos de graduação, 44 de mestrado e 17 de doutorado, totalizando 18.500 alunos (2.200 na pós-graduação). 
A Pontifícia Universidade Católica (PUC), criada em 1948, mantém 51 cursos de graduação, 10 de mestrado e 50 cursos de especialização. Lá estão matriculados 20.000 alunos, com 5\% na pós-graduação.

$\mathrm{Na}$ Região Metropolitana, agregam-se mais 2 Universidade: UNISINOS, em São Leopoldo, e a Universidade Lutera do Brasil (ULBRA), em Canoas.

Dentre os Institutos de Pesquisa destacam-se os mantidos pelo governo estadual (Motta, 1991):

- A Fundação de Ciência e Tecnologia - CIENTEC, criada em 1972, tem atribuições amplas e abrangentes nas áreas de prestação de serviços, consultoria técnica e pesquisa tecnológica, especialmente em química fina, além de manter programas em energia, agroindústria, construção civil, tecnologia ambiental e química industrial. Para isso conta com 400 funcionários, dos quais 118 com curso superior e

- Fundação de Pesquisa Agropecuária (FPA) que fora criada em 1990, mas que tem suas atividades divididas com o Instituto de Pesquisa Agronômica (IPAGRO).

A finalidade do FPA/IPAGRO é implementar a política de pesquisa e difusão tecnológica agropecuária do governo do Rio Grande do Sul. Para isso, conta com 126 técnicos de nível superior, 10 estações experimentais e de $\mathrm{P}$ x D e pesquisa básica.

Essas fundações realizam trocas de tecnologias com empresas privadas, através de contratos, de transferência de tecnologia, convênio etc.

Porto Alegre conta, ainda, com centros de pesquisa privados da Riocell, Olivebra, Polisul, $\mathrm{PPH}$ e das tintas Renner.

A esse conjunto de organismos técnico-científicos, agregam-se mais o Centro Tecnológico do Couro, Calçados e Afins, e o SENAI, que realiza pesquisas tecnológicas nas áreas de Couro e Calçados e de mecânica de precisão.

Ante essa estrutura, presente em Porto Alegre, desenvolvem-se a partir dos anos 80, as atividades "de ponta", tomando a noção de pólo tecnológico com a utilização dos recursos de diferentes órgãos públicos, Universidades e do setor privado.

O que marca o Pólo Tecnológico de Porto Alegre é o Centro de Biotecnologia, domínio que abrange imunologia, genética, biologia molecular, bioquímica e biofísica, com resultados muito voltados para a agropecuária. $\mathrm{O}$ ponto focal é o Centro que começou a funcionar em instalações modestas na Secretaria da Agricultura do Estado em 1982, com 3 doutores e 3 mestres.

Conforme Santos (1991), a história do Centro de Biotecnologia inicia-se nos últimos meses de 1981, culminando com o convênio entre a UFRGS, o governo estadual, a Fundação de Aparo à Pesquisa (FAPERG), o Banco de Desenvolvimento do Estado (BADESUL) e as Secretarias da Agricultura e da Saúde e Meio-Ambiente, para a implantação do núcleo de pesquisa, apoiado por instituições de pesquisa afins e empresas privadas diretamente interessadas no uso de processos e produtos biotecnológicos desenvolvidos pelo Centro". A iniciativa de criar o Centro de Biotecnologia no Rio Grande do Sul fora fortalecido pelo Programa Nacional de Biotecnologia (CNPq e FINEP) e no interesse da FINEP em criar um centro de pesquisa forte de tecnologia "de ponta", fora do eixo Rio - São Paulo. 
Com o desenvolvimento de engenharia genética, o Centro chegara à elaboração de vacinas, capacitando-se a transferir tecnologia às empresas. A excelência a que chegara, davalhe poder de exigir do Estado participação em investimentos e da UFRGS a criação de um Departamento de Biotecnologia de que resultaria, em 1988, um Centro novo, agora próximo os Campus, onde se desenvolveria formação de pessoal (biólogos, farmacêuticos, químicos, agrônomos, médicos) que aprofundaria estudos de pós-graduação no exterior, para fortalecer as pesquisas.

Assim estabelecido e consolidado, o Centro dispõe de 9 laboratórios e conta com 11 doutores e 1 mestre. 


\section{Um caso: o Pólo tecnológico de São Carlos}

\subsection{Organização Espacial}

\section{a) A cidade}

São Carlos (SCar) é uma cidade tangenciada a norte e leste pela Rodovia Washington Luiz que, em direção sudeste, interliga-se à Via Anhanguera, e para noroeste, segue para Araquara.

A principal entrada para o viajante que vem da Capital é a avenida Getúlio Vargas, uma semi-reta leste-oeste com aproximadamente $3 \mathrm{~km}$, que forma um ângulo de $90^{\circ} \mathrm{com}$ a Avenida São Carlos que perfaz um percurso em torno de $5 \mathrm{~km}$ no sentido norte, seccionando a cidade em duas áreas, onde habitavam aproximadamente, 143.000 pessoas em 1989.

Dados oficiais indicam a seguinte ocupação territorial da cidade:

Tabela 11 - São Carlos: Ocupação territorial

\begin{tabular}{l|r|r}
\hline Utilização dos terrenos & Área (há) & $\%$ \\
\hline Vazios & 3263,7 & 61,23 \\
\hline Residencial & 1478,3 & 27,73 \\
\hline Comercial & 343,2 & 6,44 \\
\hline Industrial & 244,4 & 4,6 \\
\hline Total & 5329,6 & 100 \\
\hline
\end{tabular}

Fonte: Assessoria de Planejamento da Prefeitura Municipal de São Carlos, 1990.

Grande parte das áreas vazias decorre da rede de drenagem natural (córregos Lazarini, Medeiros, Paraíso, Sta. Maria. Do Leme etc.), não muito valorizadas pelo capital imobiliário e que têm propiciado paisagens bucólicas ao ambiente urbano de São Carlos.

A FEPASA ainda detém amplas áreas no sudoeste da Cidade em torno da linha férrea (uma parte fora desapropriada pela Prefeitura para um Distrito Industrial, o que detalharemos mais adiante). A ferrovia tem se apresentado como fronteira entre as moradias dos trabalhadores e da classe média.

Em fins dos anos 80, havia na cidade 3 hospitais e 7 postos de saúde, com 520 leitos disponíveis, ou seja, um leito para 275 habitantes. Executando as clínicas particulares, havia 143 médicos e 176 dentistas. Lembramos que quase todas as ruas contam com rede de esgoto, eletricidade e água potável de boa qualidade.

O setor de serviços é expressivo: 2050 estabelecimentos comerciais, 20 bancários, 27 hotéis, 20 pensões, 350 advogados, 245 enfermeiras, 27 farmacêuticos e 14 contadores. 
Mais de $90 \%$ da mão-de-obra é empregada pela iniciativa privada. Segundo dados da Prefeitura, a população economicamente ativa da Cidade é de 75 mil pessoas: 52 mil homens e 23 mil mulheres. A renda per-capita é de 5.000 dólares, o que faz São Carlos ter 43 mil veículos de passageiros ou um carro para cada 4 pessoas. (Revista VEJA, Especial, 1/11/89).

O capital imobiliário tem investido, nos últimos anos, na verticalização de São Carlos, especialmente na zona central, não apenas para uso comercial, como também para residências de padrão mais elevado.

Por tratar-se de uma cidade centenária ligada à história do café, muitos de seus prédios apresentam linhas arquitetônicas representativas da cultura européia, especialmente italiana, o que tem sido resguardado ante o avanço da modernidade que domina os interesses imobiliários. Essa aparência, ao mesmo tempo bucólica e clássica, sob um clima tropical isento de poluição e intempéries, dá a São Carlos um ingrediente de atração, exponenciada por seu povo educado, "comunicativo, envolvente e acolhedor", no dizer de uma moradora da cidade.

É nesse ambiente com ar de história de vida que se aloca uma comunidade de cientistas, de professores e estudantes universitários, proporcionalmente muito alta em relação à população total da Cidade. Em quatro décadas a criatividade local do saber e da projeção econômica constrói nova realidade para São Carlos: O Parque de Alta Tecnologia ou, simplesmente, o Pólo Tecnológico.

\section{b) A evolução econômica}

Nossa preocupação inicial volta-se a compreender o processo de formação das bases que possibilitaram São Carlos se transformar em um meio técnico-científico-informacional. Em primeiro plano, tomamos uma síntese de sua história econômica.

São Carlos se insere num dos eixos de expansão da macro-metrópole, portanto com um processo moderno de dinâmica industrial ligado à política de descentralização industrial dos anos 70, um dos circuitos de montagem dos componentes deste Pólo Tecnológico.

Com 143.000 hab. no final dos anos 80, São Carlos é uma das chamadas "cidades médias" na porção centro-leste do Estado de São Paulo, a $230 \mathrm{~km}$. da Capital, distância que não a exclui da região que se estende pela linha da ferrovia da Companhia Paulista, fortemente integrada à Metrópole (Corrêa, 1968: 64).

Conforme Lorenzo (1979), a incorporação ao complexo cafeeiro de São Paulo se fez a partir de 1884, quando, para a construção do caminho de ferro, se transferiram os lucros da cafeicultura ativada por braços escravos desde 1840, e após 36 anos, por colonos imigrantes europeus que deram o tom da formação étnica e econômica de São Carlos de hoje.

Antes da chegada do Século XX, estabeleceram-se as condições inerentes à atividade industrial, cujo embrião se projetara com as oficinas mecânicas ligadas à rede ferroviária, (Truzzi, 1986: 159), com as fabriquetas de "fundo de quintal" orientadas ao atendimento da cafeicultura e à subsistência da população do município que, em 1886 , já era de 16.104 hab. e em 1900 se elevou a 27. 729 hab.

Além de soerguer sua principal igreja, SCar, nos anos 50 do século XIX, abre suas escolas de $1^{\circ}$ grau. Em 1876-78 circulam 4 jornais, a sociedade tem um clube e é atendida por um consultório médico; a década de 80 inicia-se com a elevação da vila à categoria de cidade, que já dispõe de cemitério, ostenta um prédio da Câmara, o trem conecta os negócios com a Capital e com o porto de 
Santos e a cidade utiliza-se de um banco para seus negócios. No decênio último do século, a população sancarlense tem uma estrutura urbana com serviço de iluminação pública e sistema de água e esgoto, as primeiras linhas telefônicas, além do teatro municipal. Fontes utilizadas por Devescovi (1 987:58) indicam uma população urbana de 5. 000hab. em 1891 e em 1894 de 8. 000 hab., com grande participação de imigrantes estrangeiros e seus descendentes que não se envolveram com as atividades agrícolas.

Observando em conjunto com Mamigonian (1 976), é provável que o distanciamento da estrutura econômico-social latifundiária escravista facilitou a muitos dos imigrantes a ascensão econômico-social.

Com a incorporação ao complexo cafeeiro, a região de São Carlos no século XX obedeceu ao alinhamento do processo industrial do Estado de São Paulo. Daí Lorenzo (1979) circunscrever a evolução industrial de São Carlos em dois grandes períodos: um antigo (1900-1930) e um moderno.

No início do século XX, surgem as primeiras indústrias de transformação na Cidade, com 8 máquinas de beneficiamento agrícola e cerca de 46 estabelecimentos, apesar da crise de superprodução que atingiu a cafeicultura.

A partir da primeira metade da $2^{\circ}$ década, São Carlos se consolida como centro regional, com economia agrícola mais diversificada, sem abandonar o café, e um conjunto de estabelecimentos industriais, 111 em 1920 e 143 em 1 930. Esse avanço da economia industrial, nas décadas iniciais do século XX, estava, ainda, subordinado à atividade cafeeira e ao mercado local.

Esse mercado local embora propiciasse condições para as atividades comerciais, industriais e de serviços, não assegurava à vida econômica local uma base substancial para enfrentar mais tarde a concorrência externa. "A classe média urbana, composta, basicamente por profissionais liberais e de funcionários administrativos; os vários pequenos industriais e comerciantes; um pequeno contingente de força de trabalho urbana; uma diminuta burguesia industrial nascente e a burguesia agrária eram os usuários dos meios de consumo coletivos urbanos e representavam um mercado local para as unidades comerciais e industriais" (Devescovi,1987:59-60). Os negros libertos aglutinaram-se na periferia, formando "um bairro de negros, existente ainda hoje e conhecido por Vila... Isabel” (Truzzi, 1986:57)

Enquanto a crise da cafeicultura em 1929 consolida a atividade industrial de São Paulo, com um crescimento intenso entre1929-1937, São Carlos sofre a desestruturação e decadência do processo de atividade industrial, principalmente ante à concorrência das empresas de centros mais próximos da Capital, indicação da fragilidade das bases em que se montou a indústria incipiente de São Carlos e limitada ao mercado local.

Realinhando-se às novas condições, com o aprendizado da crise e não mais se ilhando ao mercado local, os industriais sancarlenses, em grande parte formados por imigrantes, encontram na "complementação das brechas de mercado deixadas pelo pólo central da indústria" a condição favorável para uma nova fase do crescimento industrial. Dentro dessa estratégia, a partir dos anos 50 é notado um crescente aumento dos estabelecimentos e da produção industrial, sobressaindo-se a indústria de compressores e de geladeiras (Indústria Pereira Lopes), que criou oportunidade para o surgimento de outras na região (Lorenzo, 1 979: 103)

Esse crescimento foi também significativo na diversificação dos gêneros industriais, o que levou Truzzi (1986) a comparar com outros dois maiores centros industriais da região (gráfícos 4 e 5) e, ainda, frisar: "Ao iniciar a segunda metade do século, a cidade havia logrado construir um parque 
Industrial relativamente expressivo, cuja maior peculiaridade em relação a aqueles de sua região fosse talvez sua diversidade.

\section{Gráfico 4}

\section{DIVERSIFICAÇÃO DO PARQUE INDUSTRIAL - Maiores ramos (1950), segundo pessoal ocupado}

Fonte: (SEADE) Produção industrial: Aspectos Gerais Segundo as Classes de Indústrias - 1950 (extraída de Truzzi, 1986)

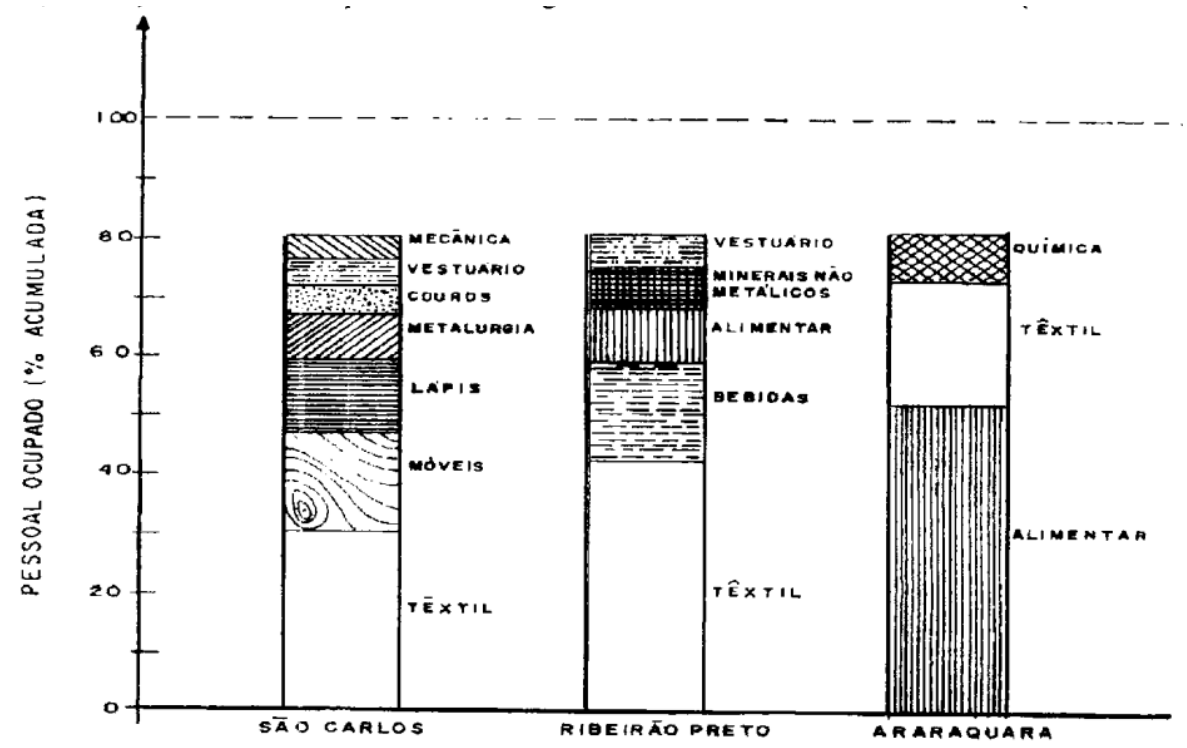

Gráfico 5

DIVERSIFICAÇÃO DO PARQUE INDUSTRIAL - Maiores ramos (1950) segundo valor de produção industrial

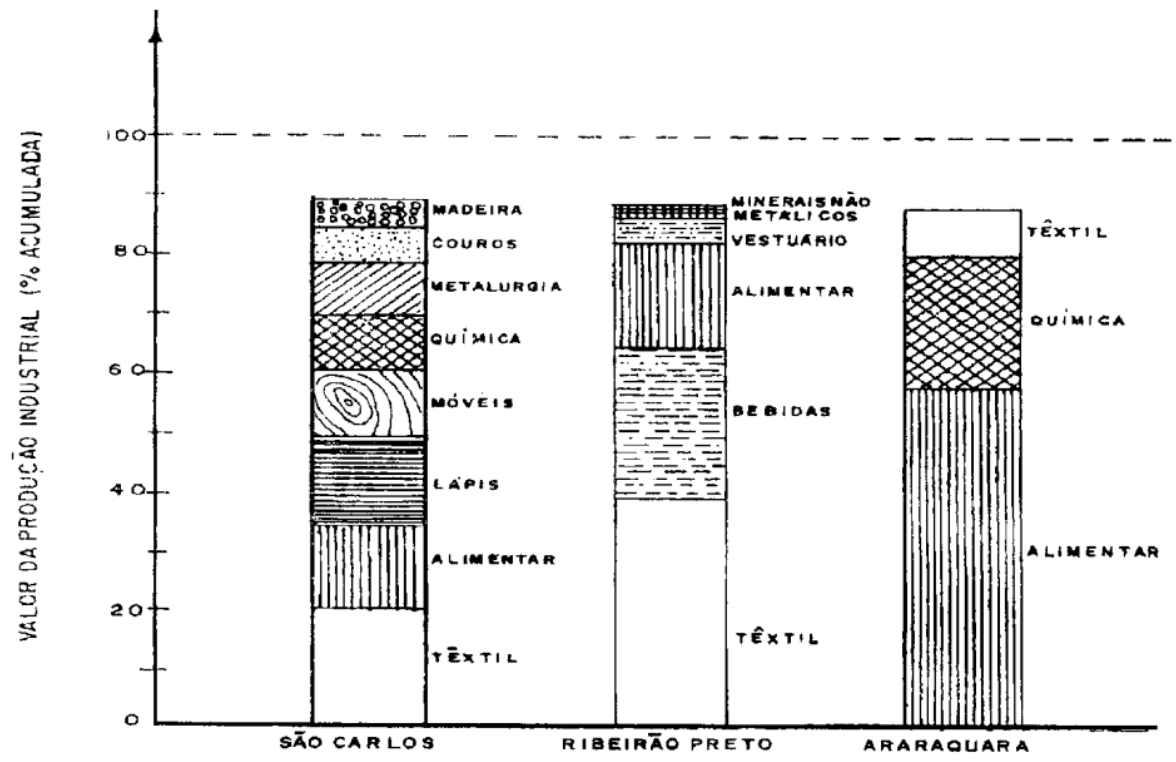

Fonte: (SEADE) Produção industrial: Aspectos Gerais Segundo as Classes de Indústrias - 1950 (extraída de Truzzi, 1986) 
É bom lembrar que nas décadas 50 e 60 algumas condições favoráveis à locação industrial foram estabelecidas em São Carlos. Nos anos $50 / 60$, através de política econômica estadual e federal, fora implementada uma rede de rodovia no interior de São Paulo, incluindo as ligações de cidades médias com São Carlos. Em 1 952, instalou-se a Escola de Engenharia de São Carlos, da USP.

No início dos anos 60 , foi regularizado o fornecimento de energia, em atendimento às reivindicações do empresariado local.

É a partir de 1 970, no entanto, que se expressa maior dinâmica, pois somente em meia década houve um aumento na produção industrial do município de $254,5 \%$ contra $110,5 \%$ na década de 1960 o que bem reflete a inserção de São Carlos na macrometrópole, conforme mencionado no início. Lima e Corrêa (1977: 615)

Confirmam esse fato: "No setor secundário, o parque industrial de São Carlos é um prolongamento da região de Campinas".

Verificado o valor da produção dos diversos setores industriais nas décadas anteriores, os setores dinâmicos (mecânicos e metalúrgicos) tomam a dianteira, com a produção local superior a 2/3, decorrente do desmembramento da Indústria de Pereira Lopes de geladeira e compressores (setor de material elétrico e comunicações). Algumas das indústrias mecânicas nascidas nos anos 40 e 50 mantêm-se como médios estabelecimentos quanto ao nível de emprego, passando por um processo de modernização tecnológica, conforme denota Truzzi (1980)

Desde o meado dos anos 60 que o poder político local se tem articulado com as lideranças econômicas, no sentido de participar do movimento de descentralização industrial da Capital, com a concessão de favores e criação de vantagens comparativas, a fim de "conquistar a preferência de novas firmas industriais". Nesse sentido, foi criado o Distrito Industrial, em 1 968, a sudeste da Cidade, o que veio contribuir para a afirmação de São Carlos como núcleo predominantemente industrial. Como a linha da Rodovia Washington Luiz tangencia o sítio urbano, implantou-se um conjunto de indústrias, às margens da rodovia, o que tem atraído o assentamento de habitações da classe operária na parte noroeste da cidade.

Pela influência junto aos governos estadual e federal na consecução de recursos financeiros e melhorias para o município, os dois maiores empresários de São Carlos, Germano Fehr e Ernesto Pereira Lopes, assumiram destacado papel na formação político econômica da Cidade.

O primeiro foi o criador de várias indústrias com projeção estadual e nacional, como a Johann Faber, cujo direcionamento fora continuado por seu filho Germano Fehr Júnior que se tornou representante regional do empresariado, ao ser eleito presidente da Delegacia do Centro das Indústrias do Estado de São Paulo - CIESP - com sede em São Carlos. Essa condição lhe possibilitou enveredar pela senda política.

Ernesto Pereira Lopes, seguiu caminho inverso. Como médico e com prestígio local, fundou um partido político, e foi eleito vereador, e, em seguida, fundou um partido político, e foi eleito vereador, e, em seguida, deputado estadual e federal. Participante do poder político, conseguiu recursos e ampliou seus negócios incipientes, galgando a formação de um complexo industrial em três décadas, inclusive com a participação de capital americano. Foi em sua época, prestigiando com o mandato de Deputado Federal pela ARENA, que São Carlos passou a sediar a única Universidade Federal de São Paulo.

Diante desses feitos é que Devescovi (1987:166) afirma, de modo quase conclusivo: “... tanto Germano Fehr quanto Ernesto Pereira Lopes, assim como alguns outros industriais de destaque no 
município, contribuíram efetivamente... para a geração das condições necessárias ao arranque e reprodução de um padrão de produção urbano-industrial no município".

Na década de 70, a taxa de urbanização de São Carlos chega a 92,2\% de uma população de 119.630 hab. no município, (Censo de 1 980), porquanto houve expressivo avanço, no dinamismo econômica, conforme comentaremos. Desde os anos 40 se agrega à vida na Cidade, um conjunto de equipamentos educacionais que iria singularizar São Carlos: Escola Industrial, SENAI, SENAC, Campus da USP e da Universidade Federal.

\section{c) São Carlos na região}

Após reordenar a espacialização de seu sistema produtivo, com duas décadas seguidas de descentralização industrial, a administração do Estado de São Paulo, em 1984, cria as regiões de Governo, com objetivo de descentralizar as ações administrativas (veja mapa 21)

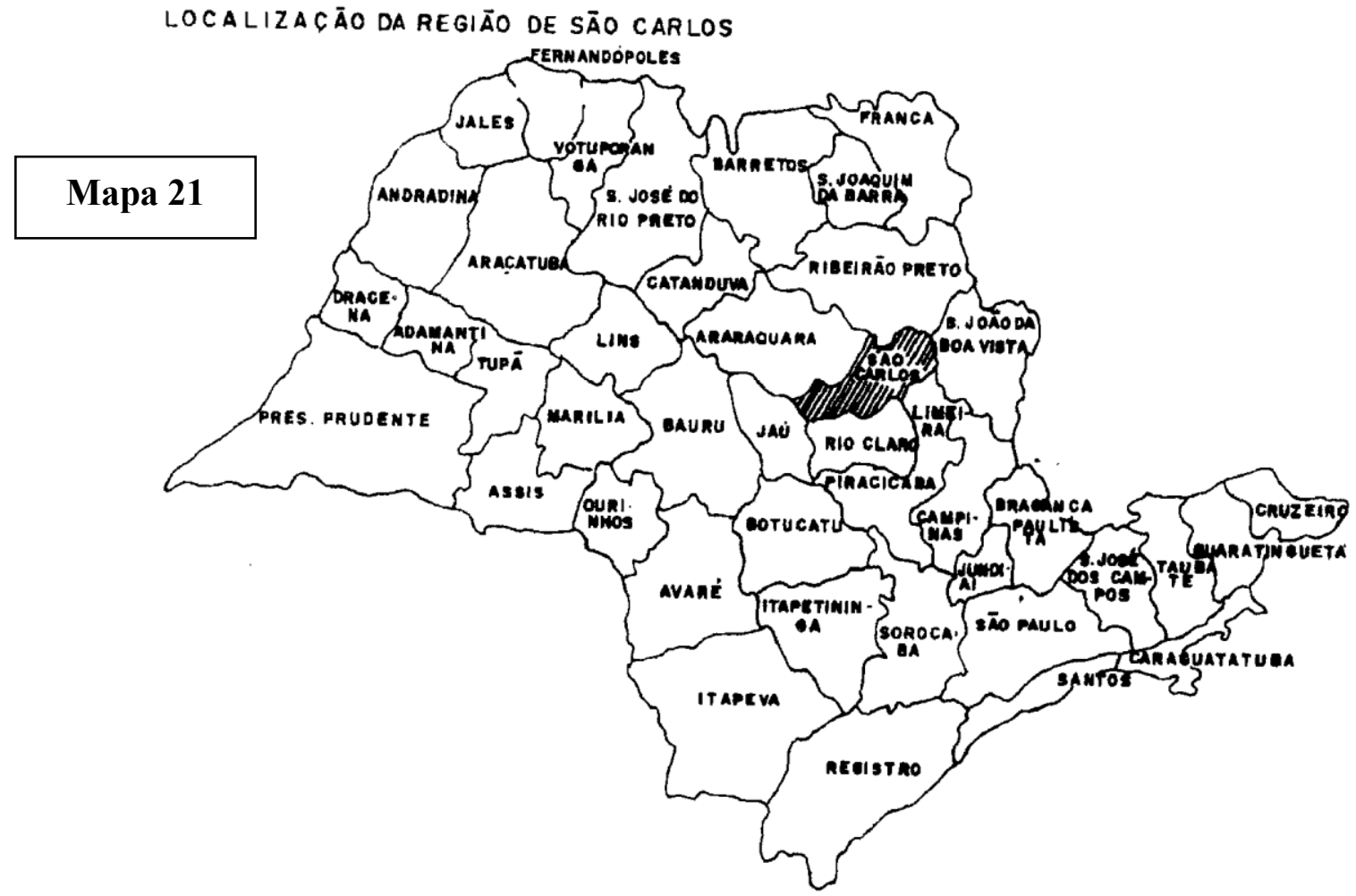

Com essa medida, inicia-se o estabelecimento nas novas sedes regionais dos órgãos de governo com jurisdição no espaço polarizado. Embora São Carlos seja uma dessas sedes regionais, em Ribeirão Preto ainda permanece a maior parte dos órgãos, porquanto desde 1 970 mantém-se como sede da Região Administrativa, a que região de São Carlos é subordinada.

São Carlos polariza seis outros municípios: Descalvado, Dourado, Ibaté, Porto Ferreira, Ribeirão Bonito e Santa Rita do Passo Quatro, como se pode observar nos mapas 22 e 23.

Os sete municípios ocupam $\left(3.829 \mathrm{~km}^{2}\right) 1.54 \%$ do território estadual, enquanto nos anos 70 e 80 sua população ( 281.567 hab. na previsão para 1989 ) só contribuía com $0,9 \%$ da totalidade dos habitantes do Estado. São Carlos tem expressiva preponderância na área regional. 
Malha viária da região de São Carlos

Mapa 22

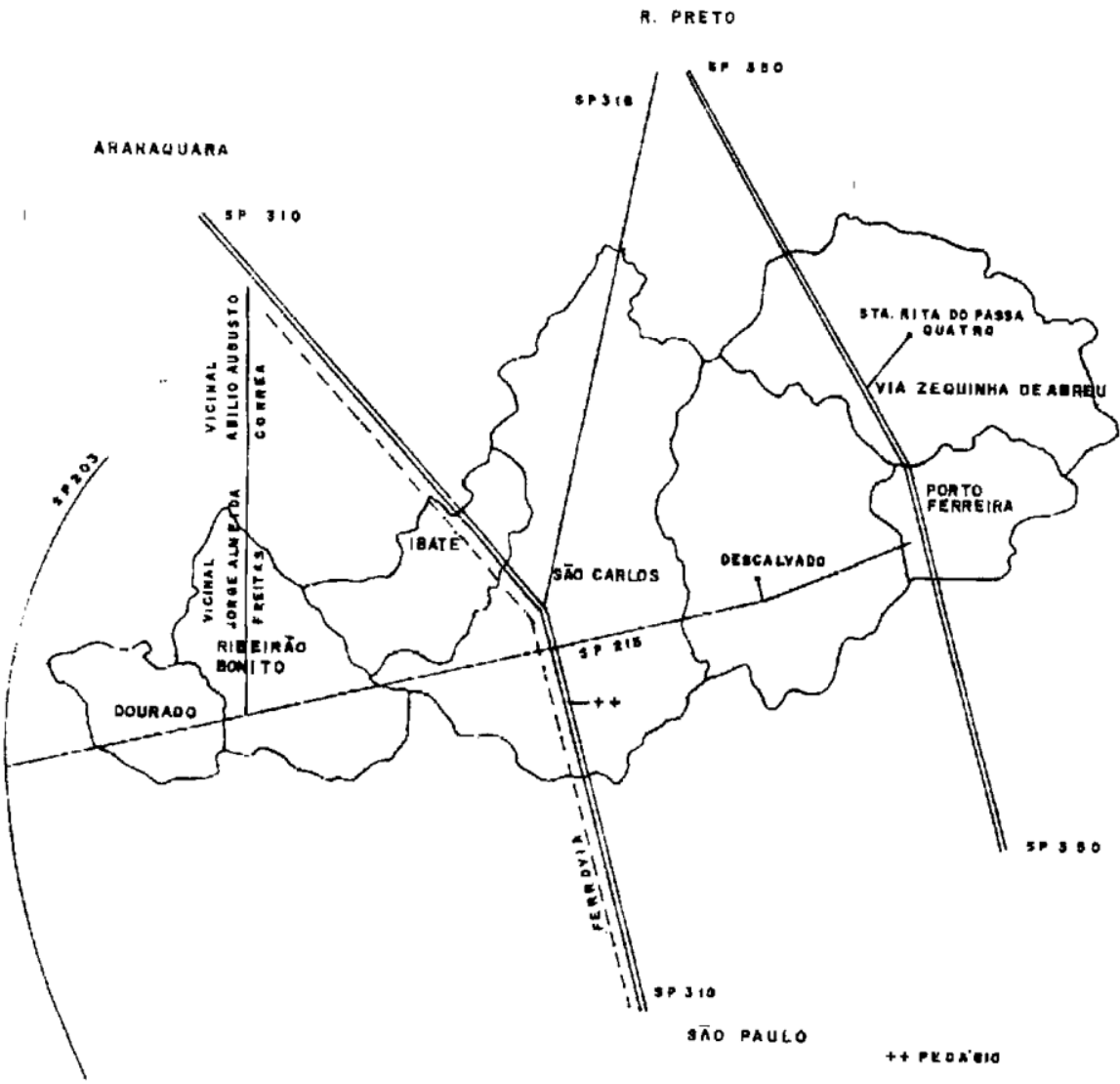

Vetores: Configuração da rede urbana regional - dez/89

\section{Mapa 23}

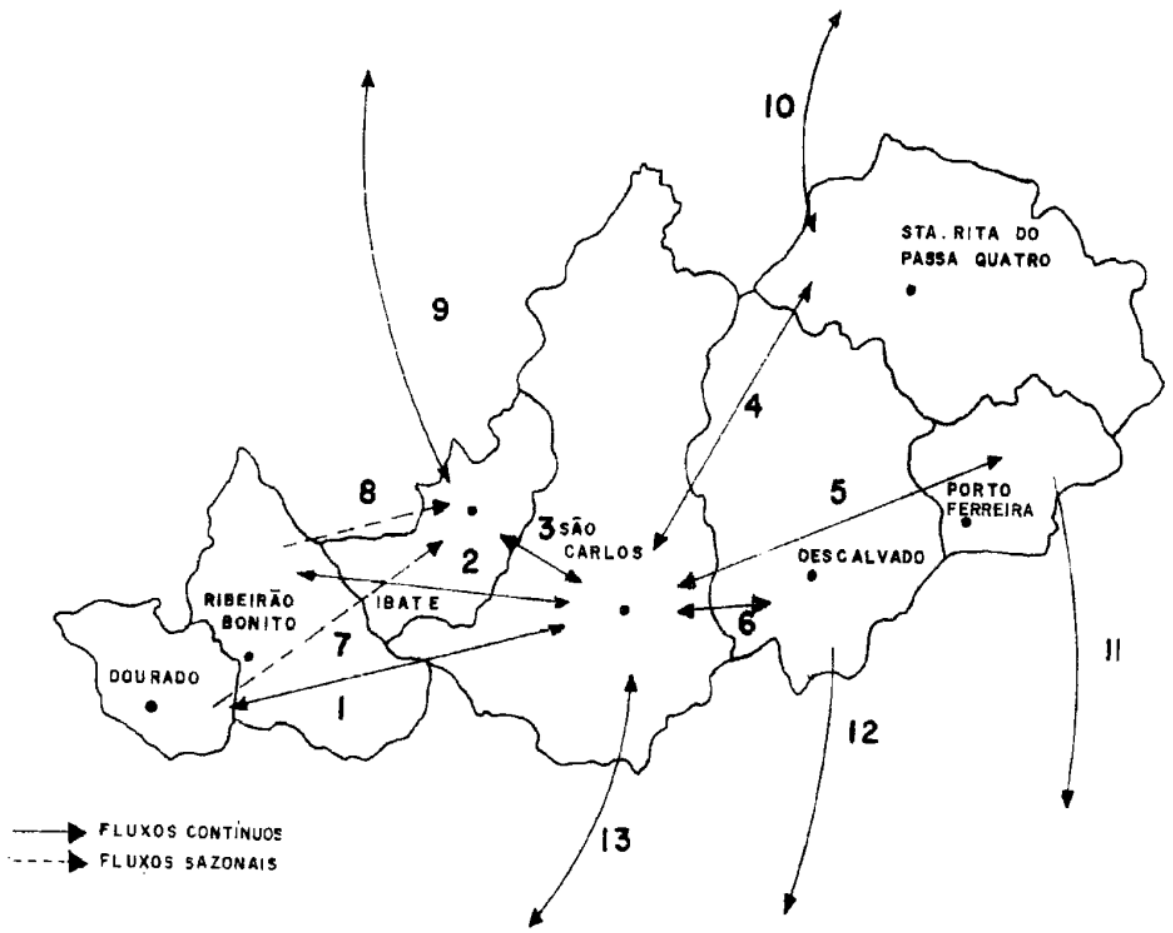

Extraído do Diagnóstico de 1990. Elaborado pelo Escritório de Coordenação de Ação Regional de São Carlos 
Por força da divisão territorial do trabalho, há contínuos fluxos entre os municípios da região, a que o Diagnóstico de 1 990, elaborado pelo Escritório de Coordenação de Ação Regional de São Carlos, descreve como vetores de interrelação dos municípios, aqui transcritos (mapa 23).

\section{“1. Dourado/São Carlos:}

Interrelação político-administrativa com a sede da região de governo; comercial varejista e escolar de nível superior.

\section{Ribeirão Bonito/São Carlos:}

Interrelação político-administrativa com a sede da região de governo; comercial varejista e escolar de nível superior.

\section{Ibaté/São Carlos:}

Interrelação político-administrativa com a sede da região de governo; comercial varejista, escolar de nível superior e mão-de-obra industrial e rural.

\section{Santa Rita do Passo Quatro/São Carlos:}

Interrelação político-administrativa com a sede da região de governo

\section{Porto Ferreira/São Carlos:}

Interrelação político-administrativa com a sede da região de governo escolar de nível superior.

\section{Descalvado/São Carlos:}

Interrelação político-administrativa com a sede da região de governo; escolar de nível superior, comercial varejista, mão-de-obra rural e industrial.

\section{Dourado/Ibaté:}

Relações econômicas rurais ligadas à mão-de-obra nas colheitas de cana-de-açúcar fornecidas a Ibaté.

\section{Ribeirão Bonito/Ibaté:}

Relações econômicas rurais ligadas à mão-de-obra nas colheiras de cana-de-açúcar fornecidas a Ibaté.

\section{Ibaté/Estado de São Paulo:}

Interrelações econômicas ligadas ao abastecimento de álcool e açúcar e, ao recebimento de mão-de-obra rural e cana produzida em outros territórios, inclusive da região de Araraquara.

\section{Santa Rita do Passa Quatro/Estado de São Paulo:}

Interrelações econômicas ligadas ao abastecimento de álcool de açúcar e, ao recebimento de mão-de-obra rural e cana produzida em outros territórios. Ainda na área agrícola produz laranja para empresas de suco localizadas em outras regiões e café para o mercado paulista.

No campo do comércio varejista e escolar de nível superior possui grande dependência da sede da $6^{\circ}$ Região Administrativa: Ribeirão Preto, por facilidades rodoviárias e transportes coletivos.

$\mathrm{Na}$ área da saúde atua como importante centro de recuperação de pacientes com distúrbios 
mentais, através do Hospital Psiquiátrico e ao mesmo tempo encaminha seus doentes com casos mais graves para Ribeirão Preto.

No campo político-administrativo tem ligações com outras regiões de governo, devido a não compatibilização de algumas Secretaria do Estado.

\section{Porto Ferreira/Estado de São Paulo e outros:}

Interrelações econômicas e comerciais com centros consumidores, a nível estadual e nacional dos produtos cerâmicos, artísticos e de construção civil, vidros e alimentos, destacando-se a capital e Ribeirão Preto.

No campo político administrativo tem ligação com outras regiões de governo, devido a não compatibilização de algumas secretarias de Estado.

\section{Descalvado/Estado de São Paulo}

Interrelações econômicas e comerciais com diversos pontos do Estado, em destaque Ribeirão Preto e Capital, que são centros consumidores de produtos avícolas, álcool, açúcar, areia industrial, laranja e café. Em contra-partida é um grande consumidor de milho e soja, matéria-prima para a fabricação de ração para avicultura.

\section{São Carlos/Estado de São Paulo/Brasil/Exterior:}

Interrelação e dependência político-administrativa da Capital, Ribeirão Preto e Araraquara, devido a não compatibilização de diversas Secretarias de Estado e empresas públicas.

No setor agro-pecuário, grande fornecedor de cana, laranja, café, leite e diversos outros produtos para o mercado estadual.

No setor industrial contribui com o abastecimento do mercado nacional e internacional de produtos industrializados como: geladeiras, lápis e canetas, materiais para escritórios, tratores, tapetes, toalhas, compressores, alimentos e diversos materiais desenvolvidos no setor de alta tecnologia.

No comércio industrial varejista e atacado recebe produtos industrializados de outras regiões e participa como consumidor em vários centros importantes como Ribeirão Preto e a Capital.

$\mathrm{Na}$ área do ensino superior, comporta-se como um celeiro estudantil, recebendo estudantes e pesquisadores de todo o país e exterior".

A produção agrícola da região, basicamente, decorre do algodão, café, da cana-deaçúcar e citrus. Dados do IBGE indicam os dois primeiros como os de menor produção e área ocupada, chegando em 1989 com uma redução de 24,0\% para o algodão e 2,1\% para o café em relação à área plantada entre 1984 e 1989 . Cana-de-açúcar teve um pequeno acréscimo da área plantada e o citrus avançou de 24.455 ha para 33.675 nos cinco anos considerados.

O que vem em destaque na pecuária é a produção de leite, criação de bovinos e a avicultura, com a liderança de São Carlos nos dois primeiros, $(36 \%$ e $35,8 \%$ respectivamente) e Descalvado no último com 53,5\%.

Com base no Sistema de Informações Municipais da FIESP/CIESP chegamos aos seguintes indicadores econômicos em referência a 1987: 
São Carlos arrecadou 70,0\% do total do ICM da Região, deixando em segundo lugar Porto Ferreira, com 22,8\%; São Carlos consumiu 56,4\% da energia regional e Porto Ferreira $23,4 \%$.

Utilizando a mesma fonte para os indicadores industriais em 1 987, o município-sede da Região de Governo e Porto Ferreira mantêm-se na liderança em número de estabelecimentos $(45,6 \%$ e $29,7 \%)$ e na totalidade de emprego industrial - $(70,0 \%$ e $14,0 \%)$. Dos 828 estabelecimentos industriais existentes na Região, 67,4\% são de micro-empresas (com até 9 empregos) que ocupam somente 5,8\% dos 30.348 pessoas ligadas à indústria. Adicionando os pequenos estabelecimentos (com 99 empregos), a proporção chega a 94,2\% ocupando $25 \%$ da mão-de-obra industrial. Em todos os portes, São Carlos detém o maior número de estabelecimentos e empregos. A dúzia de grandes estabelecimentos (nove em São Carlos) chega a concentrar em torno de $50,0 \%$ dos empregos, o que confirma Davidovich (1 977:528):

"Nos municípios ao longo da Ferrovia Paulista processa-se a transição para o interior, observando-se que diminui, gradativamente, a quantidade de estabelecimentos muito grandes e que neles são absorvidos menos de 50,0\% do pessoal ocupado na indústria, como em Americana, Limeira e outros".

Quanto aos gêneros de indústria de transformação (753 ao todo), algumas notas:

$\left.1^{\circ}\right)$ os de produtos de minerais não metálicos englobam $29,7 \%$ do total de estabelecimentos e 9,0\% dos empregos, situando-se a maioria (dois terços) em Porto Ferreira, dada a abundância de argila no município;

$2^{\circ}$ ) O grupo do metal-mecânica vem em seguida em número de estabelecimentos (138), mas superpondo-se aos demais em emprego (11.376), tendo São Carlos como o lugar de preferência na região ( $97,0 \%$ dos empregos e $76,8 \%$ dos estabelecimentos);

$3^{\circ}$ ) três grupos de indústrias se revelam como absorvedores de mão-de-obra: alimentar, com 3331 empregos; têxtil, com 3163 e diversas com 3. 025. Neles, São Carlos contribui, respectivamente, com: 30,6\%,68,3\% e 96,5\%, por contar com indústrias de médio e grande porte, desses gêneros.

Esses dados revelam o que Lima e Corrêa (1 977: 587) detectaram dez anos antes, ao tratarem do cinturão industrial paulista: "as cidades de Sorocaba, Piracicaba, São Carlos, Itapira e Bragança Paulista constituírem os limites deste cinturão industrial da metrópole paulistana..."

Com essa punjunça industrial, o Diagnósticos Regional de 1 990, realizado pelo Escritório da Coordenadoria de Ação Regional de São Carlos, reconhece que São Carlos "no setor industrial, contribui com o abastecimento do mercado nacional e internacional de alguns produtos industrializados como: geladeiras, lápis e canetas, materiais para escritório, tratores, tapetes e carpetes, toalhas, compressores, alimentos e diversos materiais desenvolvidos no setor de alta tecnologia."

\subsection{O SISTEMA DE FORMAÇÃO E PESQUISA DE SÃO CARLOS}

\section{a) A Universidade de São Paulo - Campus de São Paulo}

Vimos que o conjunto de instituições de ensino e pesquisa forma um dos pilares na constituição de um tecnopolo. Sua capacidade de gerar um processo de spin-off, de manter um padrão elevado de inovação e de inserir-se na rede de relações nacionais e internacionais, decorre, em parte, do corpo de 
inteligência presente no lugar ou na região, indicado pela substância das pesquisas e pela qualificação do pessoal que faz funcionar as fábricas do saber.

$\mathrm{Na}$ análise do Pólo Tecnológico de São Carlos, conheceremos, em primeiro lugar, a estrutura das instituiçoes acadêmicas e, em seguida, trataremos de seu conteúdo em termos do nível de pesquisa e de produção técnico-científica, tomando conjuntamente as duas Universidades (USP e UFSCar).

A vida acadêmica de São Carlos advém da presença de várias instituições de ensino superior (IES) instaladas na cidade a partir do final dos anos 40: Escola de Educação Física, Escola de Engenharia da Universidade de São Paulo - (duas décadas depois passando a Campus, com outras unidades de ensino e pesquisa), Escola de Biblioteconomia e Documentação, Faculdade de Direito, Universidade Federal de São Carlos e Faculdade de Administração de Empresas e Ciências Contábeis. Adicionaram-se mais ainda, um instituto de pesquisa da EMBRAPA (Empresa Brasileira de PesquisasAgro-pecuárias): o atual Núcleo (antes Unidade) de Pesquisa e Desenvolvimento de Instrumentação Agro-pecuária (NPDIA).

Em 1989, segundo dados do Escritório de Coordenação de Ação Regional de São Carlos, o total de estudantes de nível superior era de 9.745 para 1.001 professores numa cidade de, aproximadamente, 143.000 habitantes. Desse total de docentes, 88,4\%, estavam engajados na USP (391) e na UFSCar (493) e 51,3\% com nível de doutorado, pelo menos. Nas duas Universidades locais estão $69,5 \%$ dos estudantes, cursando graduação e pósgraduação.

A decisão de implantar em São Carlos uma escola de Engenharia da Universidade de São Paulo (EESC/USP) se deu nos últimos anos da década de 1940 , cujo funcionamento se fez somente em 1953. Qual a razão dessa iniciativa ? Por que se destinaria uma Escola de Engenharia a São Carlos, nesse período?

Vimos que a partir dos anos 30, com a queda da cafeicultura, iniciou-se um novo modelo de acumulação: o da industrialização através do processo de substituição de importações, com o qual se daria um elevado fluxo de população para as cidades que já dispunham de indústrias.

Apesar da crise que se abate sobre as indústrias têxteis no pós-guerra, a década de quarenta "foi marcada por um inequívoco avanço das atividades industriais em São Carlos" (Truzzi, 1986: 195), quando teve seu parque industrial mais diversificado que dos centros regionais mais importantes da região, conforme gráficos 4 e 5 (p. 134).

O movimento industrial imporia, então, ao meio urbano novas condições físicas habitação popular, saneamento, reordenamento espacial das atividades, transportes etc. - e maior divisão social do trabalho, dadas as exigências dos fluxos de bens (matéria-prima, produtos), e de pessoas e de informações. Essas novas demandas definiram, em 1947, a agenda de político de prestígio, no caso do Deputado Miguel Petrili, que influenciara na decisão do governo estadual a favor de São Carlos. O capital proporcionado pelo modelo de acumulação anterior e a formação da rede urbana dariam à região centro-leste, polarizada pelo município de Ribeirão Preto onde se destacava São Carlos, a condição de engendrar a absorção de equipamentos ao nível de uma escola de engenharia que atendesse às novas demandas do setor produtivo e do adensamento demográfico. Não foi por acaso que os primeiros cursos na EESC /USP foram de habilitação em engenharia civil e de mecânica, com 39 alunos selecionados no primeiro vestibular em 1953.

Essa unidade foi o embrião do Campus da USP que se formou no correr de duas décadas. 
A EESC /USP foi ampliada em 1971 com o funcionamento dos cursos de Engenharia Elétrica, Engenharia de Produção e Bacharelado em Matemática, junto ao bacharelado em Física, criado por Portaria em 1970.

Pelo Decreto Estadual n ${ }^{\circ} 52.580$, de 28-12-71, foram criados o Instituto de Física e Química e o Instituto de Ciências Matemáticas. Essa ampliação favoreceu, em 3-2-72, a que o Reitor Prof. Miguel Reale formalizasse o Campus da USP em São Carlos (mapa 24), situado em 32,1 ha, com uma área construída de 6,2 ha, onde funcionam as três principais unidades acadêmicas, laboratórios, oficinas, alojamentos estudantis, administração, área de lazer etc, afastado do core urbano, (mapa 26) formando atualmente o bairro Cidade Universitária, nas proximidades de áreas residenciais e do São Carlos Clube. Nesse Campus estudaram, em 1 989, cerca de 3234 alunos. acadêmica:

No final da década de 80, o Campus de São Carlos abrigava a seguinte estrutura

\begin{tabular}{|c|l|}
\hline Unidades & \multicolumn{1}{c|}{ Departamentos } \\
\hline \multirow{4}{*}{ Escola de engenharia } & 1. Arquitetura e Planejamento \\
\cline { 2 - 2 } & 2. Eletricidade \\
\cline { 2 - 2 } & 3. Engenharia Mecânica \\
\cline { 2 - 2 } & 4. Estruturas \\
\cline { 2 - 2 } & 5. Geotecnia \\
\cline { 2 - 2 } & 6. Hidráulica e Saneamento \\
\cline { 2 - 2 } & 7. Materiais \\
\cline { 2 - 2 } $\begin{array}{c}\text { Instituto de Ciência } \\
\text { Matemática }\end{array}$ & 9. Vias de Transporia de Computação e Estatística \\
\cline { 2 - 2 } $\begin{array}{c}\text { Instituto de Física e } \\
\text { Química }\end{array}$ & 10. Matemática \\
\cline { 2 - 2 } & 11. Física e Ciência dos Materiais \\
\hline
\end{tabular}

Além das três unidades, o Campus dispõe, ainda, do Instituto de Pesquisa e Aperfeiçoamento Industrial (IPAI), desde 1972, contribuindo para a relação Universidade e Comunidade; O Centro de Mecânica (CEMEFI), que reúne interesses de vários Departamentos desde 1 983; O Centro de Processamento de Dados (CPD), para apoio interno e externo desde 1966; o Centro de Tecnologia Educacional para Engenharia (CETEPE), órgão de apoio interdepartamental, funcionando desde 1980; Centro Cultural de São Carlos (CCSC) que congrega desde 1969, os valores artísticos do Campus.

Além desses setores, funcionam duas Fundações de direito privado criadas e dirigidas por docentes da USP /SCar: A FIPAI e a Fundação de Apoio à Física e à Química, que procuram viabilizar convênios e contratos entre empresas públicas e provadas e a Universidade.

A seguir tomamos dados referentes a 1 989, contidos no Anuário Estatístico da USP, de novembro de 1990 .

Nas três unidades acadêmicas da USP são oferecidas 15 áreas de concentração para mestrado, 10 para doutorado e 12 para cursos especiais, de pós-graduação. A EESC oferece 9 cursos para 420 
alunos, embora nesta unidade haja mais alunos de doutorado com destaque na área de Física Aplicada, o ICMSC desenvolve só dois cursos de mestrado (computação e matemática) e um de doutorado, além de dois especiais, totalizando 201 alunos.

\section{Mapa 24

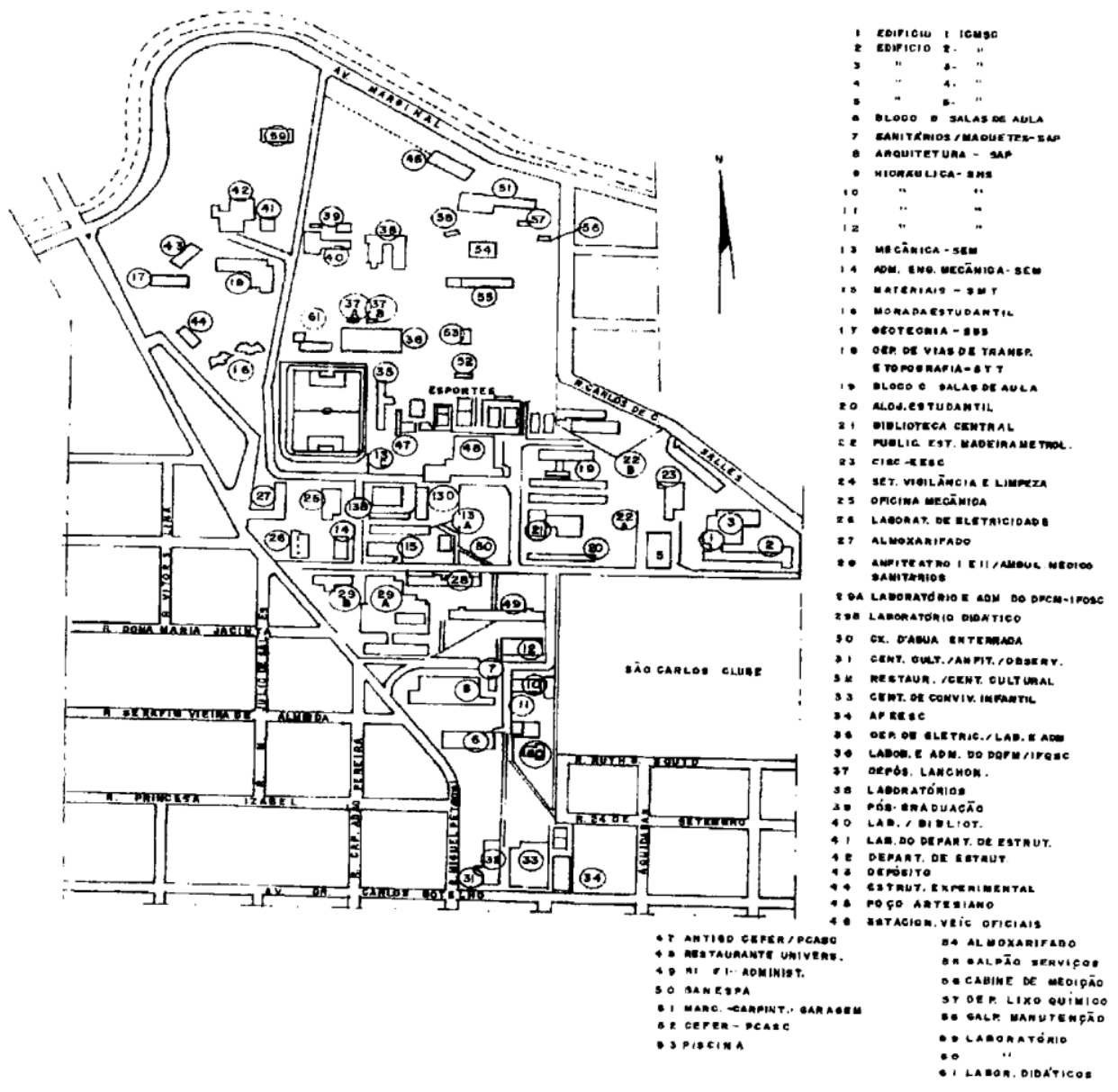

Na EESC dois cursos se ressaltam entre os demais: os de Engenharia Mecânica (181 alunos) e o de Hidráulica e Saneamento (158), cujos departamentos têm apresentado maior número de trabalhos científicos publicados, professores estrangeiros visitantes, seminários, convênios, presença em eventos acadêmicos e pesquisas em andamento.

No IFQSC são ministrados 4 cursos de mestrado para 204 alunos, 3 de doutorado, com 169 estudantes, e 1 curso especial, com 47 matrículas. Essa unidade apresenta algumas singularidades: $\left.1^{\circ}\right)$ nos últimos 5 anos $\left(\begin{array}{lll}1 & 985 & -89\end{array}\right)$ lidera em número total de trabalhos docentes, atingindo a média de 4,2 por professores, contra 1,6 da EESC e 0,7 no ICMSC; $2^{\circ}$ ) é o que mais participa de eventos 
científicos e publica trabalhos no exterior, apesar de lotar apenas $23,7 \%$ dos 391 docentes do Campus; $3^{\circ}$ ) Desde 1985 , com exceção de 1988, outorga maior número de títulos de doutorado; $4^{\circ}$ ) recebeu, em 1989,86 professores visitantes do estrangeiro, ao lado de 21 na EESC e 8 no ICMSC; $5^{\circ}$ ) mantém 51,0\% dos alunos de doutorado do Campus; $6^{\circ}$ ) todos os seus docentes têm dedicação integral à docência e à pesquisa; $7^{\circ}$ ) dispõe da maior área construída para laboratórios para Campus.

Em 1 989, as pesquisas do Departamento de Física e Ciências dos Materiais se desenvolviam com 11 grupos que agregavam 59 docentes, tendo recebido 77 professores visitantes (sendo 44 estrangeiros) e a participação de 248 bolsistas (35,5\% do doutorado). $\mathrm{O}$ conjunto de trabalhos elaborados pelos 11 grupos chega a 230, dos quais 121 publicados, 74 aceitos e 35 submetidos à publicação. Dos 66 mestrandos, 25 passaram pelas bancas examinadoras e 9 doutorandos defenderam teses, no correr do ano em referência. Essas pesquisas deram origem a 96 convênios (só o grupo de cristalografia, 28), além de 219 participações em eventos científicos, exceto os 186 seminários e palestras dentro e fora do Departamento.

Alguns grupos se sobressaem: cristalografia, em número de professores participantes; materiais, em relação a professores visitantes estrangeiros (16) e à participação de eventos e óptica, que atraiu 20 professores visitantes, 33 pós-graduandos e 35 palestras e seminários no Departamento.

Apesar da pequena quantidade de trabalhos científicos, o grupo de biofísica é um dos poucos existentes no Brasil, com a competência e projeção no cenário dessa linha de conhecimento, tanto nacional como internacionalmente.

O outro Departamento no IFQSC tem 13 (treze) grupos de pesquisa formados pelos 36 docentes que coorderam os trabalhos de 139 bolsistas $(27,3 \%$ doutorandos $)$ e 14 professores visitantes. Os resultados são mais modestos, quer em termos de publicações (70), de dissertação de mestrado (14) ou tese de doutorado (5), de convênios (32) ou de participação em eventos científicos $(1,5)$. Também se destaca o grupo de bioquímica com 2 patentes submetidas ao registro, em 1989.

Foi do ambioente do IFQSC que nasceu a UFSCar, dados o empenho e o idealismo de destacados pesquisadores da física experimental, liderados pelo Prof. Sérgio Mascarenhas, com o apoio político de dois deputados federais, na época (conforme entrevista do citado professor da USP).

\section{b) A Universidade Federal de São Carlos}

Somente após dez anos de sua criação, a Universidade Federal de São Carlos entrou em funcionamento em 1 970, época em que o empresário e deputado Ernesto Pereira Lopes tinha grande prestígio junto ao governo de Garrastazu Médici. A UFSCar teve um crescimento muito rápido, pois em 1973 já possuía 1 há de área construída que sextuplicaria a em 15 anos.

O Campus, hoje, ocupa uma área de 667 ha, que pertencera à antiga fazenda Trancham, no limite norte da cidade, onde uma represa divide o Campus em setor sul, com prédios mais antigos, e o setor norte, com as construções mais recentes. (mapa 25).

Para atender à sua clientela de aproximadamente 3.000 alunos, os 493 professores se distribuem em 19 departamentos de 3 centros; as atividades de ensino e pesquisa que transcendem o âmbito departamental são desenvolvidas por 9 órgãos designados "Unidades Especiais" (ver quadros a seguir). 
Universidade Federal de São Carlos

Centros /departamentos

1989

\begin{tabular}{|l|l|l|}
\hline $\begin{array}{c}\text { Ciências Biológicas e } \\
\text { da Saúde }\end{array}$ & Ciências e Tecnologia & \multicolumn{1}{c|}{$\begin{array}{c}\text { Educação e } \\
\text { Ciências Humanas }\end{array}$} \\
\hline 1. C. Biológicas & 1. Computação & 1. C. Sociais \\
\hline 2. C. da Saúde & 2. Eng. Civil & 2. Educação \\
\hline 3. Enfermagem & 3. Eng. de Materiais & 3. Filosofia e Metodologia \\
\hline 4. Fisioterapia e Terapia & 4. Eng. de Produção & das Ciências \\
\hline Ocupacional & 5. Eng. Química & 4. Letras \\
\hline & 6. Estatística & 5. Metodologia de Ensino \\
\hline & 7. Física & 6. Psicologia \\
\hline & 8. Matemática & \\
\hline & 9. Química & \\
\hline
\end{tabular}

Universidade Federal de São Carlos

Unidades Especiais de Ensino e Pesquisa

\begin{tabular}{|l|l|l|}
\hline $\begin{array}{l}\text { Oficina de Manutenção } \\
\text { eletrônica }\end{array}$ & Laboratório de idiomas & Biotério \\
\hline $\begin{array}{l}\text { Unidade de microsco- } \\
\text { pia Eletrônica }\end{array}$ & Unidade de Criogenia & Oficina Mecânica \\
\hline $\begin{array}{l}\text { Arquivo de História } \\
\text { Contemporânea }\end{array}$ & $\begin{array}{l}\text { Unidade de difusão } \\
\text { Cultural }\end{array}$ & Oficina de Vidraria \\
\hline
\end{tabular}

Além dessas unidades, outros setores de apoio ao ensino e à pesquisa estão instalados no Campus, tais como: Divisão de Processamento de Dados, Estação de Piscicultura, a casa de Vegetação, mais de uma centena de laboratórios, Biblioteca Central (60.000 livros e 1.700 periódicos), Gráfica, Restaurante, equipamentos de lazer etc.

No que se refere à graduação, a UFSCar oferece 16 cursos: dois (Pedagogia e Ciências Sociais) no Centro de Educação e Ciências Humanas; quatro nas áreas do Centro de Ciências Biológicas e da Saúde com habilitação em bacharelado, e dois em licenciatura plena; O Centro de Ciências e Tecnologia administra 10 cursos, entre os quais três com habilitação em licenciatura Física, Química e Matemática. As atividades de pós graduação se iniciam em 1 976, com os programas de Ecologia e Recursos Naturais, de mestrado e doutorado, e de Educação com duas áreas de concentração no mestrado, (Pesquisa Educacional e Planejamento de Ensino), aos quais se adicionam mais dois (Educação Especial e Engenharia dos Materiais) na mesma década. Desde 1 980, se sucede a instalação de sete cursos de mestrado: Química, Engenharia Química, Ciências Sociais, Matemática, Física, Filosofia e Metodologia das Ciências e Computação; os doutorados de Engenharia dos Materiais e Química são implantados 
Em 1987, com 8 e 4 matrículas, respectivamente. Desse modo, a UFSCar chega no final dos anos 80 com 11 cursos de mestrado e 3 de doutorado em atividade e um (Engenharia Química) em análise na CAPES (tabela 12)

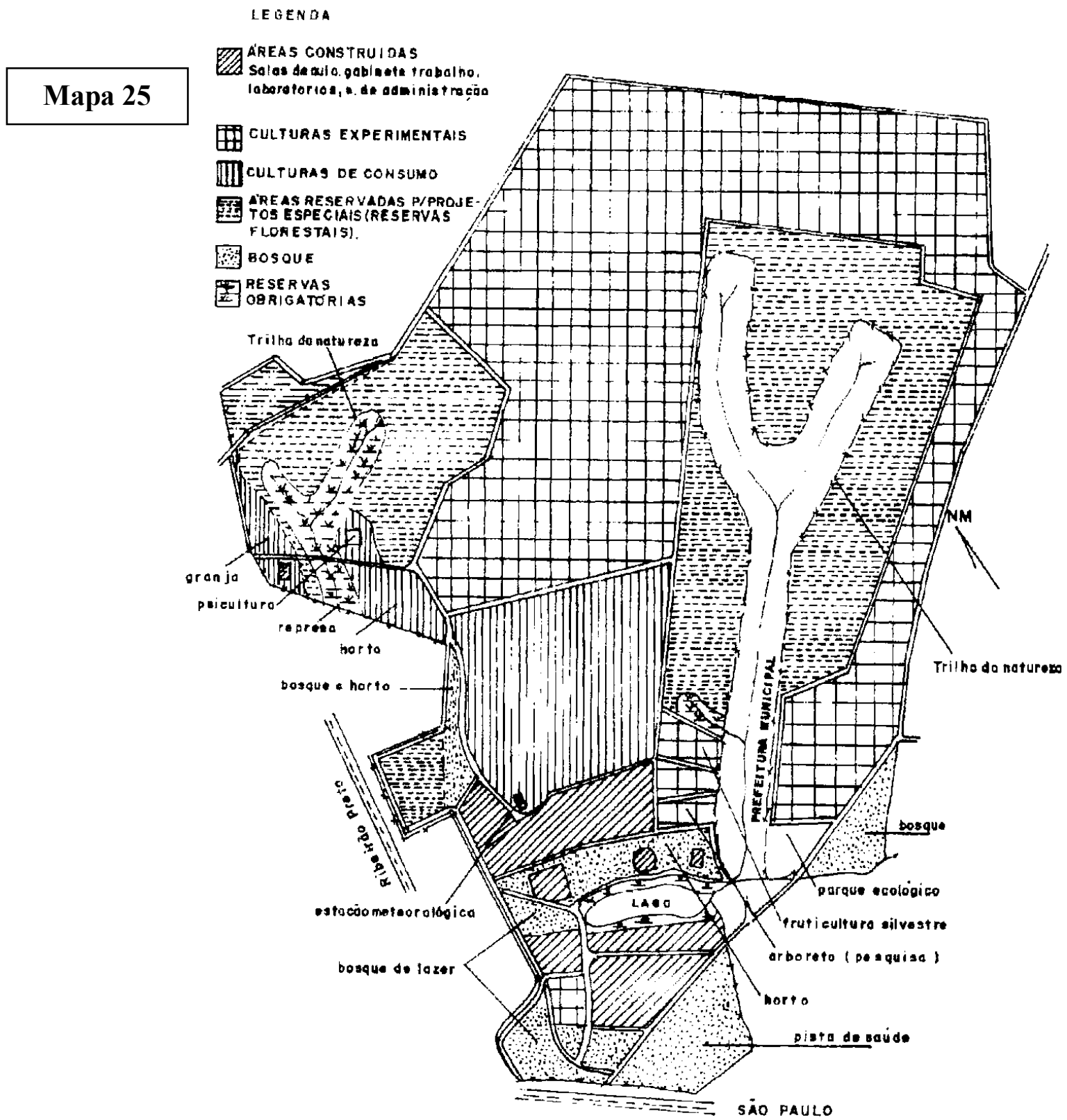

É bem claro o grande avanço da área de ciência e tecnologia nos anos 80, na UFSCar. Associando esse fato com o quadro da estrutura dos Centros e com os dados sobre os cursos de pós-graduação, logo se verifica o peso que tem o CCT na Universidade e, particularmente, na configuração do objeto de nosso estudo, o Pólo Tecnológico de SCar. Em face dessa importância do CCT, procuraremos evidenciar alguns tópicos de sua potencialidade. 
Tabela 12

Universidade Federal de São Carlos

Cursos de doutorado e mestrado - 1989

\begin{tabular}{|c|c|c|c|c|c|c|c|c|}
\hline \multirow{2}{*}{$\begin{array}{c}\text { Área de } \\
\text { conhecimento }\end{array}$} & \multirow{2}{*}{ Curso } & \multirow{2}{*}{ Área(s) de Concentração } & \multicolumn{2}{|c|}{ Matric. } & \multicolumn{2}{|c|}{ Defesa } & \multicolumn{2}{|c|}{ Prof Cred. } \\
\hline & & & M. & D. & M. & D. & UFSC & Ext. \\
\hline Ciências Biol. & $\begin{array}{l}\text { Ecologia e Re- } \\
\text { cursos naturais }\end{array}$ & $\begin{array}{l}\text { Ecologia e Recursos Naturais (M.) } \\
\text { Ecologia (D.) }\end{array}$ & 48 & 48 & 9 & 3 & 28 & 9 \\
\hline \multirow{6}{*}{$\begin{array}{l}\text { Ciências } \\
\text { Exatas e } \\
\text { Tecnologia }\end{array}$} & Computação & Sist. Avançado de Computação & 20 & & & & 4 & 3 \\
\hline & Eng. de Mater. & Metalurgia, Polímeros e Cerâmicas & 86 & 16 & 13 & & 35 & 4 \\
\hline & Eng. Química & PxD de processos químicos & 37 & & 12 & & 12 & \\
\hline & Física (f.) & $\begin{array}{l}\text { F. Atômica, F. Estatística e F. Mat. } \\
\text { Condensada }\end{array}$ & 9 & & & & 15 & \\
\hline & Matemática & M. Aplicada, Análise e Geometria & 11 & & 1 & & 18 & \\
\hline & Química (q.) & $\begin{array}{l}\text { Fís-quím., Q. Org. e Inorg. } \\
\text { Fís-Quím., e Q. Orgân. (D.) }\end{array}$ & 52 & 29 & 11 & & 21 & 3 \\
\hline \multirow{4}{*}{$\begin{array}{l}\text { Educação e } \\
\text { Ciências } \\
\text { Humanas }\end{array}$} & $\begin{array}{l}\text { Ciências } \\
\text { Sociais }\end{array}$ & A Sociedade de Classes & 15 & & & & 11 & 4 \\
\hline & Educação & $\begin{array}{l}\text { Fundamentos da Educação } \\
\text { Metodologia de Ensino }\end{array}$ & 107 & & 12 & & 21 & 5 \\
\hline & $\begin{array}{l}\text { Educação } \\
\text { Especial }\end{array}$ & Educação do Indivíduo Especial & 42 & & 4 & & 14 & 4 \\
\hline & $\begin{array}{l}\text { Fil. e Método } \\
\text { das Ciências }\end{array}$ & $\begin{array}{l}\text { Epistemologia da Psicologia e da } \\
\text { Psicanálise }\end{array}$ & 8 & & & & 7 & 3 \\
\hline Totais & 11 & 21 & 423 & 93 & 62 & 3 & 176 & 35 \\
\hline
\end{tabular}

Fonte: Catálogo dos cursos de mestrado e doutorado UFSCar, 1989.

Além de ter sido o primeiro centro a ser implantado, o CCT se destaca pelos seguintes aspectos: 1) desenvolve o maior número de cursos, especialmente de pós-graduação; 2) reúne o efetivo mais numeroso de discentes ( $72 \%$ da graduação e $49,7 \%$ da pós-graduação) e de docentes (59\% do total e $54 \%$ dos credenciados para a pós-graduação); 3 ) no relatório anual da UFSCar, de 1987, constam os professores liderando na apresentação de conferências proferidas e seminários ministrados de âmbito nacional e internacional; 4) são também dos docentes do CCT a maior participação em eventos (seminários, congressos etc), de 1987, em âmbito regional, nacional e internacional. 5) no CCT estão dois cursos de graduação (Engenharia de Materiais e Engenharia Química) com o conceito "excelente", entre apenas 46 no Brasil, e dois outros (Física e Química) considerados "muito bom", dentre 203 no País, conforme pesquisa publicada no Guia do Estudante, de 1990. Além dessas evidências, é importante observar o que revela a apresentação do Relatório do CCT de 1989:

"Os cursos tecnológicos formam profissionais em carreiras pouco oferecidas pelas Escolas e Faculdades tradicionais brasileiras, tendo adquirido caráter pioneiro no suprimento das necessidades da cooperação técnico-científica, de assistência e de formação de recursos humanos e de outras formas de intercâmbio com outras Universidades, com agências de fomento, com empresas e órgãos 
governamentais. Dentre as empresas conveniadas, podem ser citadas: IBM, Pirelli, PETROBRÁS, CBMN, PoliBrasil S.A., Cipla, Nadir Figueiredo, EMBRAPA, Philips, Cardinalli S.A., FINEP, CNPq, FAFESP, UNICAMP, Prefeitura de São Carlos e de Jaboticabal. etc.

Os recursos provenientes através de convênios institucionais e não institucionais têm gerado recursos da ordem de oito vezes mais que os recursos orçamentários".

Sem olvidar o papel que desempenham os demais departamentos da UFSCar na atmosfera de cultura técnico-científica que domina São Carlos, veremos que os departamentos de Química e de Engenharia dos Materiais apresentam certas qualidades que os tornam expoentes no processo de criação de empresas de base tecnológica e na difusão de São Carlos como eficiente pólo tecnológico.

O departamento de Química, criado em 1971, tem sob sua responsabilidade 3 cursos de graduação com 175 alunos matriculados, e 2 de pós-graduação, sob a regência de 32 doutores e 5 mestres com dedicação exclusiva à atividade da UFSCar. A formação acadêmica da maior parte desse quadro se fez no Instituto de Química da USP (18), no IFQSC (9) e no exterior (6).

O programa de pós-graduação iniciou-se com o mestrado no segundo semestre de 1980; sete anos depois, foi implantado o doutorado. Havia em 1989, 46 alunos no mestrado e 28 no doutorado.

O DQ conta com grupos de pesquisas nas diversas áreas da Química e em ensino de Química, voltados aos aspectos básicos das pesquisas planejadas e às aplicações diretas ou indiretas que delas possam decorrer. As atividades se realizam através de 15 laboratórios que ocupam uma área construída de $6.000 \mathrm{~km}^{2}$, a que se agregam docentes altamente qualificados com equipes formadas por alunos de iniciação científica de mestrado e doutorado, apoiados por recursos das instituições públicas e de empresas privadas, conforme mostra a tabela 13. Na coluna "outros", de órgãos financiadores, relacionam-se: Secretaria de Ciência e Tecnologia da Presidência da República e a do Estado de São Paulo, o MEC, a Internacional Foundation for Science (Suécia), TELEBRÁS, USIMINAS, Companhia Bras. de Metalurgia e Mineração (CMMM), Companhia Paranaense de Eletricidade, 3M do Brasil e Carbonatos do Nordeste.

"O grande número de atividades de pesquisa nas distintas áreas da química tem permitido uma grande interação com o setor produtivo, (...) realizar inúmeras prestações de serviços, consultorias técnico-científicas e resoluções de problemas técnicos". (Relatório do DQ, 1990:31)

Outro indicativo do nível do DQ é sua produção científica, sintetizada nos gráficos 6 a 9, (p. 148)extraídos do Relatório de Informações e Atividades Desenvolvidas do Departamento de Química, UFSCar., São Carlos, 1990.

A produção científica do Departamento de Química iniciou-se por volta de 1980, quando a maior parte de seu corpo docente completou sua formação de mestrado ou doutoramento.

A outra fração do CCT da UFSCar que se dimensiona como vetor do desenvolvimento técnico-científico de São Carlos é o Departamento de Engenharia de Materiais (DEMa). O DEMa tem tido forte participação junto ao setor empresarial (Rachid, 1991), o que veremos mais adiante. 
Tabela 13

Universidade Federal de São Carlos

Departamento de Química (DQ) do CCT

Atividades de Pesquisa - 1989

\begin{tabular}{|c|c|c|c|c|c|c|c|c|c|c|c|}
\hline \multirow{3}{*}{$\begin{array}{c}\text { Laboratório dos Grupos de } \\
\text { Pesquisa }\end{array}$} & \multicolumn{5}{|c|}{ Pessoal } & \multicolumn{5}{|c|}{ Órgãos financiadores } & \multirow{3}{*}{$\begin{array}{l}\mathrm{N}^{0} \text { de } \\
\text { Apli- } \\
\text { ca- } \\
\text { ções }\end{array}$} \\
\hline & \multirow{2}{*}{$\begin{array}{l}\text { Prof. } \\
\text { Resp. }\end{array}$} & \multirow{2}{*}{$\begin{array}{l}\text { Prof. } \\
\text { Visit. }\end{array}$} & \multicolumn{3}{|c|}{ Bolsistas } & \multirow{2}{*}{$\begin{array}{l}\text { Fi- } \\
\text { nep }\end{array}$} & \multirow{2}{*}{$\begin{array}{l}\text { Fa- } \\
\text { pesp }\end{array}$} & \multirow{2}{*}{$\begin{array}{l}\text { Ca- } \\
\text { pes }\end{array}$} & \multirow{2}{*}{$\begin{array}{l}\mathrm{CN}- \\
\mathbf{P q}\end{array}$} & \multirow{2}{*}{$\begin{array}{l}\text { Ou- } \\
\text { tros }\end{array}$} & \\
\hline & & & I.C. & M. & D. & & & & & & \\
\hline Cinética Química & 1 & - & 4 & 4 & 2 & - & $\mathrm{x}$ & $\mathrm{x}$ & $\mathrm{x}$ & $\mathrm{x}$ & 5 \\
\hline Difração de Eletrons & 3 & - & 4 & 2 & 1 & $\mathrm{x}$ & $\mathrm{x}$ & & $\mathrm{x}$ & $\mathrm{x}$ & 3 \\
\hline Eletroquímica e Polímeros & 7 & - & 4 & 19 & 10 & - & - & $\mathrm{x}$ & $\mathrm{x}$ & $\mathrm{x}$ & 6 \\
\hline Espectroscopia & 1 & - & - & - & - & $\mathrm{x}$ & $\mathrm{x}$ & $\mathrm{x}$ & $\mathrm{x}$ & - & 7 \\
\hline Bioquímica & 2 & - & 4 & 2 & 3 & $\mathrm{x}$ & $\mathrm{x}$ & - & $\mathrm{x}$ & - & 2 \\
\hline Eletroquímica e Cerâmica & 3 & 3 & 14 & 12 & 9 & $\mathrm{x}$ & $\mathrm{x}$ & - & $\mathrm{x}$ & $\mathrm{x}$ & 18 \\
\hline Química Analítica & 4 & - & 9 & 6 & - & $\mathrm{x}$ & $\mathrm{x}$ & - & $\mathrm{x}$ & $\mathrm{x}$ & 7 \\
\hline Humus e Química Ecológica & 1 & - & 2 & 2 & 3 & - & - & $\mathrm{x}$ & - & - & 3 \\
\hline Produtos Naturais & 4 & - & 9 & 3 & 6 & $\mathrm{x}$ & $\mathrm{x}$ & $\mathrm{x}$ & $\mathrm{x}$ & - & 2 \\
\hline Química Inorgânica & 3 & - & 2 & 5 & - & $\mathrm{x}$ & - & - & $\mathrm{x}$ & - & 5 \\
\hline Quím. dos Sol. Inorgânicos & 1 & - & 4 & 4 & - & - & $\mathrm{x}$ & $\mathrm{x}$ & $\mathrm{x}$ & $\mathrm{x}$ & 5 \\
\hline Química Teórica & 5 & - & 2 & 2 & 4 & $\mathrm{x}$ & $\mathrm{x}$ & $\mathrm{x}$ & $\mathrm{x}$ & - & 4 \\
\hline Síntese Orgânica I & 3 & - & 6 & 10 & 5 & $\mathrm{x}$ & $\mathrm{x}$ & $\mathrm{x}$ & $\mathrm{x}$ & $\mathrm{x}$ & 2 \\
\hline Síntese Orgânica II & 2 & - & 2 & 5 & 8 & $\mathrm{x}$ & $\mathrm{x}$ & $\mathrm{x}$ & $\mathrm{x}$ & $\mathrm{x}$ & 3 \\
\hline Ensino de Química & 3 & - & - & - & - & - & - & $\mathrm{x}$ & - & - & 1 \\
\hline
\end{tabular}

Fonte: Dep. de Química - Informações e Atividades Desenvolvidas UFSCar - 1990.

Mesmo que o DEMa tenha sido criado somente em 1972, dois anos antes já funcionava o curso de graduação em Engenharia de Materiais, "como um lançamento pioneiro na América Latina", fruto do ideário e luta de pesquisadores em Física do Estado Sólido que tinham ligações acadêmicas com o Dep.de Ciência e Engenharia de Materiais da Universidade de Princeton (EUA) e desejavam "fazer de São Carlos o centro pioneiro da física experimental no Brasil”, (Prof. Sérgio Mascarenhas), ainda nas décadas de 50 e 60.

Em 1 979, o DEMa instala o curso de mestrado (M) e em 1987, o de doutorado (D).

No final dos anos 80, o DEMa tem em seus quadros 45 docentes, 44 com dedicação exclusiva, 30 com a titulação de doutor e 12 com mestrado. Em 1989, o Departamento contou com nove professores visitantes.

Doze linhas de pesquisas englobam cerca de 110 trabalhos e projetos em desenvolvimento (veja tabela 14), apoiados pela FINEP, CNPq, FAFESP, FNDCT, MCT e mais de 40 instituições públicas e privadas, entre as quais a Universidade de Aveiro (Portugal), a Universidade Federal do Rio Grande 
do Sul, a EMBRAER, a Clímax, Pirelli, Philips do Brasil, UNICAMP, Copessucar, Lápis Johann Faber, 3M do Brasil, Cerâmica Portobello, ENGESA, algumas empresas de São Carlos, Confab, NGK do Brasil etc.

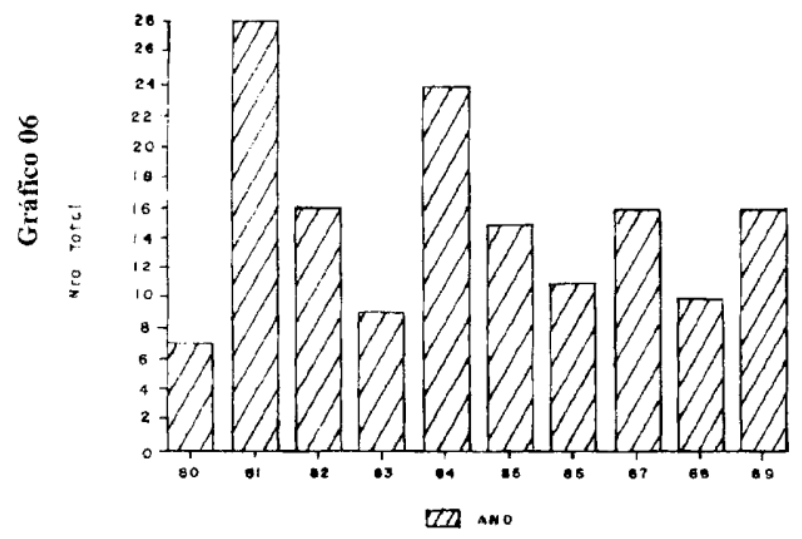

Evolução da produção científica do DQ: publicaões em revistas internecionais.

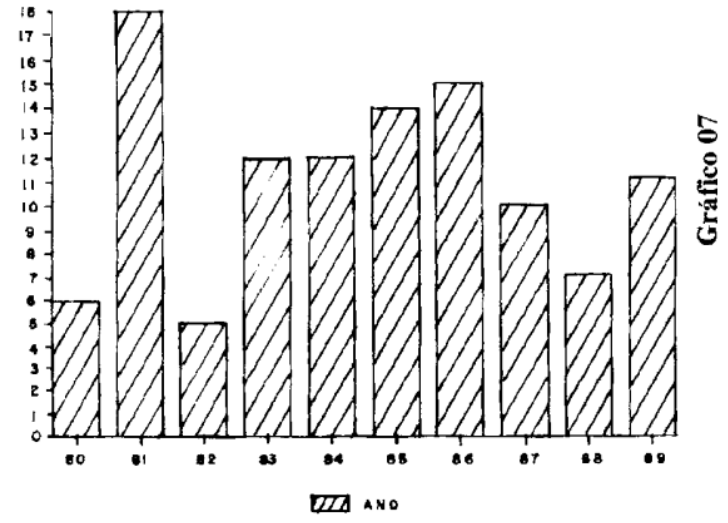

Evolução da produção científica do DQ: publicações em revistas nacionais.

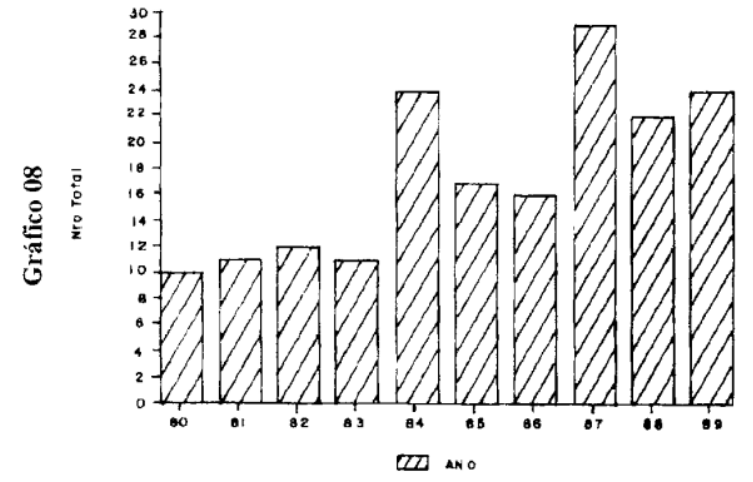

Evolução da produção científica do DQ: trabalhos apresentados $\mathrm{em}$ congressos internacionais.

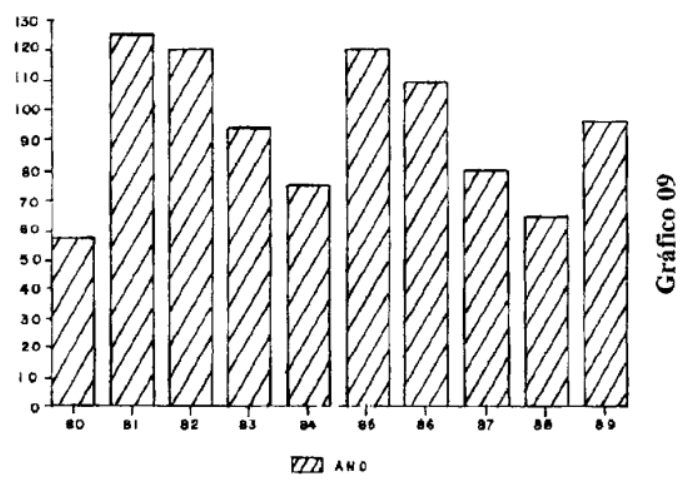

Evolução da produção científica do DQ: trabalhos apresentados em congressos nacionais. 
Tabela 15

Universidade Federal de São Carlos

Departamento de Engenharia de Materiais - CCT

Linha de Pesquisas

\begin{tabular}{|c|c|c|}
\hline $\mathbf{N}^{\mathbf{0}}$ & Linha de Pesquisa & $\begin{array}{c}\text { Trabalhos e } \\
\text { Projetos } \\
\text { Desenvolvidos } \\
\end{array}$ \\
\hline 1 & Desenvolvimento de Materiais Avançados & 13 \\
\hline 2 & Desenvolvimento de Mat. para Fabricação & 26 \\
\hline 3 & Propriedades Mecânicas de Materiais & 14 \\
\hline 4 & Processamento e Conformação de Materiais & 15 \\
\hline 5 & Prop. Físicas e Termodinâmicas dos Materiais & 22 \\
\hline 6 & Formação e Transformação de Fases em Materiais & 1 \\
\hline 7 & Corrosão e Degradação de Materiais & 1 \\
\hline 8 & Análise de Microestrutura e Morfol. das Fases em Materiais & 4 \\
\hline 9 & Instrumentação para Materiais & 3 \\
\hline 10 & Modelagem e Simulação em Materiais & 4 \\
\hline 11 & Desenvolvimento do Ensino em Engenharia & 5 \\
\hline 12 & Característica Química de Materiais & 2 \\
\hline \multicolumn{2}{|r|}{ Total } & 110 \\
\hline
\end{tabular}

Fonte: Relatório do DEMa - 1990

É expressiva a produção científica do DEMa, como se pode verificar na tabela 15.

Tabela 15

Universidade Federal de São Carlos

Departamento de Engenharia de Materiais - CCT

Produção Científica - 1985-89

\begin{tabular}{lcrrrr}
\hline \multicolumn{1}{c}{ Publicação } & $\mathbf{1 9 8 5}$ & $\mathbf{1 9 8 6}$ & $\mathbf{1 9 8 7}$ & $\mathbf{1 9 8 8}$ & $\mathbf{1 9 8 9}$ \\
\hline em periódicos nacionais & 6 & 11 & 14 & 9 & 17 \\
em periódicos estrangeiros & 10 & 11 & 5 & 7 & 13 \\
em Anais de Congresso Nacional & 9 & 43 & 27 & 67 & 25 \\
em Anais de Congresso Internacional & 10 & 6 & 9 & 11 & 9 \\
\hline Total & 35 & 71 & 55 & 94 & 64 \\
\hline
\end{tabular}

Fonte: Relatório do DEMa - 1990 
Nos dois últimos anos (1988 e 1989), os recursos financeiros de DEMa têm se originado mais de fontes externas, isto é, convênios e contratos com órgãos públicos (FINEP, CNPq, FAFESP) e algumas empresas (com pequena participação), como se pode ver no gráfico 10.

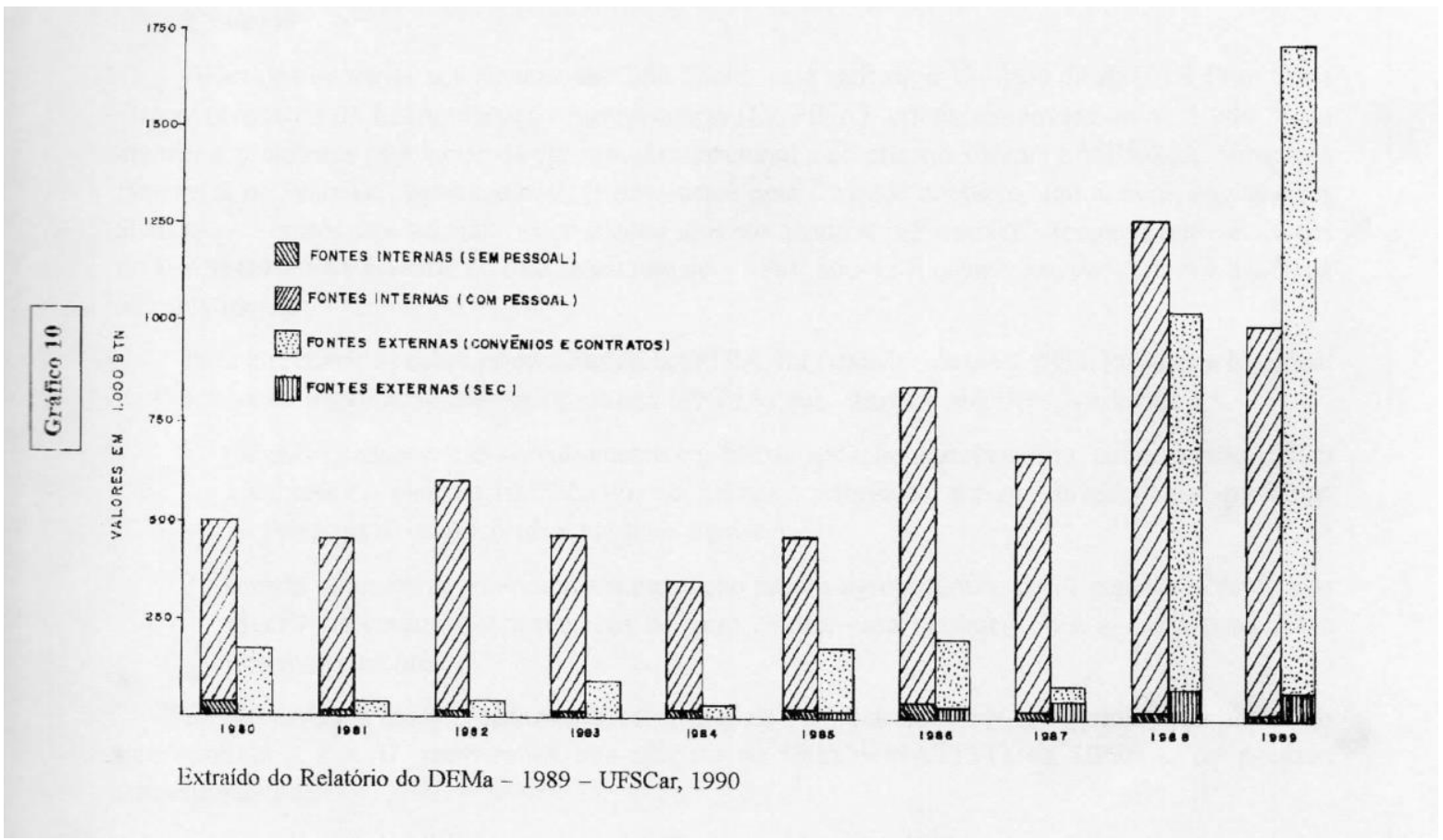

\section{d) Unidades Isoladas.}

O pólo tecnológico de São Carlos é marcado também pela presença de cursos da área humanística, tanto na UFSCar como em Escolas e Faculdades Particulares.

Três unidades isoladas completam o quadro do sistema acadêmico da Cidade, cujos dados estão sintetizados na tabela 16 .

Tabela 16 - São Carlos - SP

Unidades Acadêmicas Isoladas

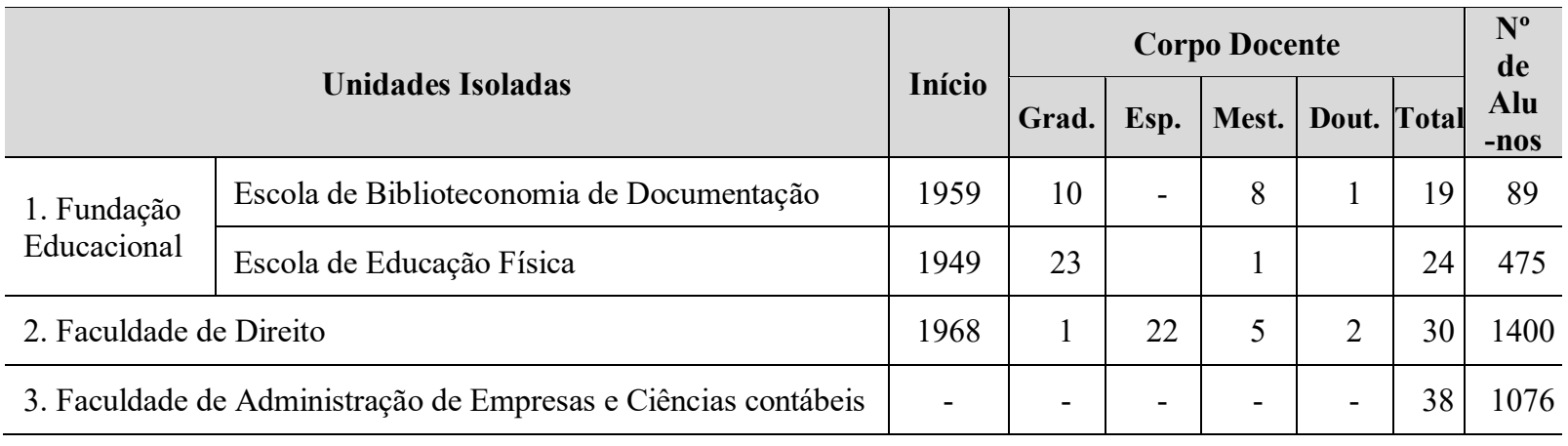

Fonte: Dados coletados in loco - 1990 . 
É interessante observar que somente $30 \%$ dos alunos matriculados na Escola de Educação Física São Carlos e 20\% dos docentes da Faculdade de Direito procedem de Araraquara.

\section{EMBRAPA.}

Além das unidades acadêmicas, em São Carlos está sediada a Unidade de Apoio à Pesquisa e Desenvolvimento de Instrumentação Agropecuária (UAPDIA), criada em novembro de 1984 "para atender a prementes problemas da agropecuária nacional e do próprio sistema EMBRAPA. (Empresa Brasileira de Pesquisa Agropecuária). É certamente uma Unidade diferente, com físicos, engenheiros eletrônicos e outros profissionais pouco encontrados nos quadros da EMBRAPA", como revela o edital do INFORMATIVO DA UAPDIA, n $\mathrm{n}^{\mathrm{0}} 1$ de Jan/Junho de 1 986). São 42 funcionários, dos quais14 ligados à administração.

Para direcionar as ações prioritárias da UAPDIA, foi estabelecido em 1985 o Programa Nacional de Pesquisa de Instrumentação (PNPIA) que, entre os objetivos, se dispõe a

$\left.1^{\circ}\right)$ realizar pesquisas e desenvolvimento em Instrumentação Agropecuária, em cooperação com Unidades do Sistema EMBRAPA, em primeira prioridade, e com Universidades, Institutos de Pesquisa e outros órgãos públicos e privados.

$2^{\circ}$ ) formar recursos na área de instrumentação para a agropecuária, desde especialistas de alto nível (pós-graduação) e técnicos de grau médio, para manutenção e apoio à pesquisa e desenvolvimento.

Em decorrência desse ordenamento, até o final de 1 989, destacamos os seguintes resultados, no que respeita a $\mathrm{P} \times \mathrm{D}$, registrados nas edições do INFORMATIVO da UPDIA, do período correspondente.

01 - A UAPDIA introduziu, de forma pioneira no cenário nacional e internacional, novo método de estudos em Física da água no solo, usando a tomografia e a minitomografia computadorizadas. Tal trabalho foi desenvolvido no Brasil, (envolvendo o IFQSC, Fundação Educacional de Barretos, CNPq e FINEP) em cooperação com a Itália (Centro Internacional de Física de Trieste, IASAUNESCO, Universidade de Trieste e Roma).

02 - Em colaboração com a Fundação Educacional de Barretos, a UFSCar, Controle e Automação Digital (São Carlos), CNPq e FINEP, a UAPDIA desenvolveu um computador com sistema de sensores de tensiômetros, para leitura do potencial matricial da água do solo.

03 - Construção de um minitomógrafo de Raio x e Raios gama de baixo custo, dedicado a estudos da Ciência do solo, de fisiologia vegetal, engenharia biomédica e fins industriais. O projeto conta com o apoio e colaboração do Centro de Engenharia Biomédica da Universidade de Roma.

04 - Foi desenvolvida por um pesquisador da UAPDIA uma câmara fototérmica aberta, particularmente adequada para medidas espectroscópicas in vivo para um vasto campo de aplicação em vegetais. 
05 - Foi concluído um controlador de temperatura para estufas, podendo ser usado no controle geral da temperatura de fornos, muflas e estufas, na faixa de 25 a $200^{\circ} \mathrm{C}$, e que requeiram precisão de $0,1^{\circ} \mathrm{C}$.

06 - A UAPDIA construiu um equipamento para medir o período de folhamento foliar, de vital importância para os fitopatologistas e produtores.

07 - Pioneiramente, foi desenvolvido todo um espectrômetro de ressonância magnético nuclear para seleção não-destrutiva de sementes oleaginosas, quanto ao teor de óleo.

08 - A AUPDIA, em colaboração com outros órgãos, desenvolveu um analisador de hidrogênio, com inúmeras vantagens sobre os outros cromatógrafos de condutividade térmica.

09 - A AUPDIA desenvolveu e construiu um micromanipulador destino à bissecção de embriões ovinos, de grande interesse econômico.

10 - Foi desenvolvido o medidor digital multisensor de temperatura para solos, com aplicações em vários campos.

Agrega-se a esses resultados de P x D o fato de a UAPDIA ter conseguido a realização, em São Carlos, em 1998, da Escuela Latino Americana de Física de Suelos, com a participação de cientistas de vários países detentores de elevado perfil científico e tecnológico.

Outro aspecto é a formação de recursos humanos na múltipla fronteira $\mathrm{P} \times \mathrm{D}$, de instrumentação agropecuária de doutorado e mestrado em colaboração com Unversidade nacionais e estrangeiros.

É necessário registrar que a criação e o desempenho administrativo e científico desse órgão muito se deve ao Prof. Sérgio Mascarenhas, físico de renome internacional, integrado à USP-SCar desde 1956 e que, nos anos 60, coordenou a formação da UFSCar.

\section{3 Alguns Indicadores do Nível Técnico-Científico de São Carlos}

Após essa visão, um tanto sumária, de cada Instituição de Ensino e Pesquisa, relacionaremos alguns indicadores do potencial técnico-científico de São Carlos, que talvez explicitem algumas das razões do enquadramento dessa Cidade na escala tecnopolitana.

Desenvolveremos a análise em dois tópicos principais:

a) estágio de pesquisa (recursos humanos e materiais, infra-estrutura, relação internacional etc.) e

b) produção científica dos docentes, publicações, defesas de trabalhos etc).

Consideremos, inicialmente no item a) a relação população urbana e população acadêmica:

1) há uma média de 317 habitantes para cada docente com título de doutor das 2 universidades. 
2) essa média baixa para 144, se considerados todos os professores universitários da cidade:

3) mais presentes ainda na vida urbana de São Carlos quando consideramos docentes e discentes: entre cada grupo de 14 habitantes há um preocupado com as atividades acadêmicas. Isto é notado no cotidiano da cidade. Por conseguinte, se agregarmos os 1500 servidores das 2 universidades, então, em cada 12 pessoas de São Carlos, haverá, certamente, uma ligada ao trabalho intelectual de nível superior. São índices, verdadeiramente, expressivos para uma cidade do $3^{\circ}$ mundo!

No lastro de sua radiante vida em SCar, a USP fez medrar a formação de 1575 mestres e 335 doutores, e a UFSCar 393 e 40. respectivamente, de que resultam trabalhos e idéias definidoras do cenário em que se mostra o meio técnico-científico que conhecemos no interior paulista.

Abertas ao público e conectados ao sistema de telecomunicações, as bibliotecas (das 2 universidades) guardam um acervo, sempre atualizado num contexto mundial, em torno de 135.000 livros, 6.000 periódicos e alguns milhares de teses, dissertações, monografias, áudio-visuais, jornais, documentos oficiais e históricos etc.

O corpo de pesquisadores é servido por eficientes equipamentos de informática (mainframe, workstation etc.), o que faz SCar ter as condições para atender às necessidades relativas ao ensino, à pesquisa e administração.

A esses recursos adicionam-se valores intelectuais do estrangeiro: somente em 1989 foram mais de cem pesquisadores de dezenas de países, (em destaque EUA, Grã-Bretanha), que convivem meses com os cientistas de São Carlos. Aqui não se incluem as comissões, os grupos de diferentes países que visitam por alguns dias as atividades da USP, da UFSCar, da UAPDIA ou das empresas. A cooperação internacional se dá através de professores visitantes recebidos em São Carlos ou enviados a diversos países, ou mesmo através de convênios celebrados. As trocas científicas com os demais países é outra via tomada pelos pesquisadores de SCar, pois, só em 1 989, 214 docentes participaram de eventos no estrangeiro.

As pesquisas em andamento são contabilizadas em centenas, especialmente em razão do número de matrículas nos cursos de doutorado e mestrado, sendo os projetos e convênios apoiados com recursos de órgãos públicos e empresas privadas nacionais e internacionais.

No que se refere ao segundo ítem (produção científica), tratemos das publicações de docentes das 2 universidades. De 1985 a 1988 a evolução foi expressiva: 1392, 1519, 1678 e 1926, o que nos dá um aumento relativo de 9,12\% entre 1987 e 1988 . Nessa evolução, notase um sucessivo crescimento relativo na produção de trabalhos. Dados de 1987 e 1988 nos revelam semelhante comportamento no crescimento de trabalhos publicados no exterior, 206 e 185 , portanto, $28,3 \%$ de aumento nos dois anos de referência.

A média de trabalho por docente das 2 universidades esta em torno de 2,3.

Tem se mantido a média de 40 títulos de doutorado outorgados por ano, ou mais precisamente: 1985, 40; 1986, 39; 1987, 42; 1988, 44.

São Carlos tinha 424 estudantes nos 17 programas de doutorado. Para os cursos que outorgam esse título em São Carlos, a avaliação da CAPES nos anos 85/86 e 86/87 tem variando em A e B. De 10 cursos avaliados, somente dois desceram ao nível C. 


\subsection{As empresas de alta tecnologia em São Carlos}

Na segunda metade da década passada foi substancial o surgimento de empresas de base tecnólogica em São Carlos, o que se constata com os dados da tabela 17, provenientes de pesquisa de campo junto a 24 das 50 empresas associadas à FPATCS. A escolha das empresas foi aleatória. Torkomian (1992) também constata em estudo de 30 empresas, 63,3\% criadas entre 1986-91 e que nenhuma tem mais que 20 anos.

\section{Tabela 17}

Parque de Alta Tecnologia de São Carlos

Instalação de Empresas: evolução

\begin{tabular}{l|r|r}
\hline \multicolumn{1}{c|}{ Período } & \multicolumn{1}{c|}{$\mathbf{N}^{\mathbf{0}} \mathbf{1}$} & \multicolumn{1}{c}{$\%$} \\
\hline Antes de 1980 & 2 & 8,3 \\
\hline De 1980 a 1984 & 8 & 33,3 \\
\hline De 1985 a 1990 & 14 & 58,4 \\
\hline Total da Amostra & 24 & 100,0 \\
\hline
\end{tabular}

Fonte: Pesquisa Direta: jan. 1991

O impulso se deve, em muito, aos incentivos da Fundação Parque de Alta Tecnologia, FPATSC - criada em fins de 1984, sob os auspícios do CNPq, Prefeitura de São Carlos e outros órgão em conjunto com as Universidades. Entre outros objetivos, a FPATSC "promove a passagem das tecnologias criadas nas Universidades e Institutos de Pesquisas a empresas nacionais existentes ou a serem criadas em São Carlos".

Apesar de mencionarmos somente 10 empresas de alta tecnologia em funcionamento antes da existência da FPATSC, em São Carlos já havia, no total, 18 delas conforme relatório da Fundação de 15/9/1986.

Essa preferência em investir em empresas desse perfil motivou estudiosos a diagnosticarem o fenômeno e traçarem o contorno do novo símbolo dessa cidade paulista.

Os mais destacados estudiosos da organização tecnopolitana de São Carlos (Lima, Ferro, Torkomian, 1987) relacionaram quatro fatores básicos responsáveis pelo surgimento dessas empresas:

1 - "Existência de uma overdose de ciência durante um longo período de tempo". A melhor comprovação desse fato está no que vimos sobre o sistema de pesquisa e formação existente na Cidade, desde os anos 50.

A formação de empresas com base nos conhecimentos científicos torna-se quase inevitável em vista de haver forte desempenho das engenharias na vida acadêmica de São Carlos. Em Rachid (1991), isso fica bem evidenciado, especialmente na listagem de empresas criadas a partir do Departamento de Engenharia de Materiais (DEMa) da UFSCar: 


\begin{tabular}{|c|c|c|c|}
\hline Empresa & Funcionários & Ano Criação & Produtos \\
\hline Engemassa & 193 & 1976 & $\begin{array}{l}\text { Ligas fundidas de aços inoxidáveis e } \\
\text { superligas à base de cobalto }\end{array}$ \\
\hline EDG & 40 & 1977 & $\begin{array}{l}\text { Fornos industriais para laboratório de } \\
\text { odontologia, maçaricos de hidrogênio. } \\
\text { Sistemas de limpeza de peças }\end{array}$ \\
\hline Cetebra & 20 & 1980 & Produtos de alumina para tubos pirométricos \\
\hline Keramos & 37 & 1984 & $\begin{array}{l}\text { Cordierita, mulita, cristobalita para fundição de } \\
\text { precisão, pó para polimento, aluminatato de } \\
\text { bário para aplicações especiais de cerâmica }\end{array}$ \\
\hline Procer & 9 & 1984 & Peças cerâmicas de elavo teor de alumina \\
\hline Litema & 20 & 1985 & Peças fundidas em ligas especiais \\
\hline Engecer & 30 & 1986 & $\begin{array}{l}\text { Pós para polimento, sensores de zircónia e de } \\
\text { alumina, consultorias }\end{array}$ \\
\hline Kappa & 5 & 1986 & $\begin{array}{l}\text { Processos de metalização de cerâmica, solda } \\
\text { vidro/metal e ligas especiais para empresas } \\
\text { eletro-eletrônicas e telecomunicações }\end{array}$ \\
\hline $\begin{array}{l}\text { D'amico e } \\
\text { Pelegrino }\end{array}$ & 24 & 1986 & $\begin{array}{l}\text { Materiais para tratamento ortodôntico e } \\
\text { ortodonpediátrico }\end{array}$ \\
\hline $\begin{array}{l}\text { Quantum } \\
\text { (S.S. } \\
\text { Campos) }\end{array}$ & 10 & 1987 & $\begin{array}{l}\text { Produtos de alumina, mulita/zircônia, } \\
\text { consultorias }\end{array}$ \\
\hline Hitech & 2 & 1987 & $\begin{array}{l}\text { Consultoria e software para reformulação de } \\
\text { corpos cerâ- } \\
\text { micos, softwares aplicativos à tecnologia } \\
\text { cerâmica }\end{array}$ \\
\hline Panmol & 7 & 1988 & $\begin{array}{l}\text { Materiais refratários para lingoteamento } \\
\text { contínuo, válvulas longas e submersa e tampão } \\
\text { monolítico }\end{array}$ \\
\hline Cerauto & 10 & 1988 & Termistores \\
\hline Dematech & 2 & 1990 & $\begin{array}{l}\text { Assessoria e consultoria tecno-científica, } \\
\text { cursos, projetos, desenvolvimento, ensaios e } \\
\text { processos materiais }\end{array}$ \\
\hline
\end{tabular}

De professores e técnicos da USP surgiu umas das mais destacadas empresas Extraído de Rachid (1991:F-40 e 41). de alta tecnologia de São Carlos: a Opto Eletrônica. Essa é a única firma a pagar royalty à Universidade, por tecnologia repassada.

Esse transbordamento de ciência nas unidades de pesquisa de São Carlos, talvez, possa também ser indicado pelos 30 produtos e processos apresentados como inovações por 15 das 24 indústrias de nosso estudo. Cinco destas trabalham com 3 a 5 inovações.

Dezoito empresas, conforme pesquisa de campo, foram originadas por professores (9), ex-alunos (10), e/ou técnicos (4) das duas Universidades. É provável que este dado também possa servir como identificador da veiculação das atividades científicas com a formação de empresas de alta tecnologia em SCar.

Nas 24 empresas por nós consideradas há a presença de uma ou mais pessoas, entre os sócios, com a formação de engenheiro, professor ou técnico da Universidade. Metade dessas empresas investe em P x D. 
2 - Presença em São Carlos de espírito de empreendedor, quer de empresários, quer de "doublê" cientista-empresário e de alunos técnicos.

A evolução econômica de São Carlos comprova essa tendência, "característica de ambição, persistência, gosto pelo desafio, capacidade persuasória e capacidade de lidar com desafios", no dizer dos autores acima citados. Isso se torna ainda mais patente, ao analisarmos a origem do capital social das firmas: 20 delas $(83,3 \%)$ nasceram com recursos próprios dos sócios, cientes e que estão entrando em negócios de alto risco, sem nenhum apoio das agências de crédito governamental e sem vivência de cipoal de gerenciamento e de marketing e da concorrência. Nestes aspectos, nove empresas mostraram-se em dificuldades de conseguir financiamento, $5 \mathrm{em}$ desenvolver marketing e 7 relevando-se inexperientes em administração ou gerenciamento.

3 - Influência do parque de indústrias tradicionais existente, dando condição para aproveitamento de experiências e da mão-de-obra capacitada. Nesse nível, há décadas, em São Carlos assentaram-se indústrias de geladeiras, compressores de geladeiras e condicionadores de ar, tratores, materiais escolar e de escritório, tapetes, toalhas etc., o que expressa um mercado de trabalho diversificado que dispõe da mão-de-obra menos qualificada. Isso contribuiu para atender a parte da força-de-trabalho desse novo corpo de firmas emergentes.

4 - Apoio dos órgãos de fomento à pesquisa. No exame dos grupos de pesquisa no interior das Universidades são vários e variados os casos de recursos provindos dos conhecidos órgãos públicos de apoio a programas de pesquisa, cujos resultados serão rapidamente repassados a protótipos e às linhas de produção. A série de indústrias derivadas do DEMa encontram-se nesse contexto.

Adicionaremos, ainda, alguns outros fatores que refletem a importância da organização espacial como força na construção desse novo tempo de São Carlos:

5 - São Carlos faz parte do eixo da macrometrópole, importante vetor da descentralização industrial, com um parque produtivo de quase 600 unidades fabris, além de exercer papel de centro-regional na porção interiorana mais rica do Estado de São Paulo, popularizada pela media como a "Califórnia Brasileira".

Essa condição amplia as inflûencias de São Carlos para outras cidades médias de São Paulo e outros centros nacionais, no que concerne à conquista de clientes para inovações de bens e processos, antes privillégio de grandes firmas ou de outros países. Em 24 indústrias de alta tecnologia de São Carlos, identificamos um mercado bastante difuso, como se pode ver na tabela 18 .

Essa ligação (ou dependência?) com as grandes empresas se explica nos vários tipos de produtos elaborados em SCar, quase sempre suprimentos tecnológicos antes importados pelas maiores firmas, comumente concentradas nas metrópoles. Esse fato é muito bem sintetizado nas palavras de um dos empresários de São Carlos: "as micro-empresas trabalham para as grandes, manufaturando aquilo que elas não querem fazer mais, por estarem num estágio de produção mais avançado".

A condição de admitir-se nos nichos de mercado, geralmente abertos pelos processos de 
desintegração ora vigente na nova organização da produção das grandes empresas, leva a maioria das PMEs dos Tecnopolos a se ligarem a clientes externos a seu local e á sua região. No caso das empresas sancarlenses de alta tecnologia, Torkomian (1992) identificou 18, dentre 30 estudadas, que tiveram o nicho mercadológico como motivo básico de sua criação.

Tabela 18

Parque de Alta Tecnologia de São Carlos

Mercado das Empresas

\begin{tabular}{l|c|c}
\hline \multicolumn{1}{c|}{ Área dos Clientes } & $\begin{array}{c}\text { Grandes } \\
\text { Empreas }\end{array}$ & PMEs \\
\hline Região metropolitana de São Paulo & 9 & 6 \\
\hline Interior do Estado de São Paulo & 6 & 5 \\
\hline São Carlos & 4 & - \\
\hline Todo o Estado & 4 & 1 \\
\hline Todo o País & 3 & - \\
\hline Exterior & 1 & \\
\hline
\end{tabular}

Fonte: Pesquisa direta, janeiro/91

Desse modo, ao se realçar a amplitude espacial do mercado, restringem-se, por conseguinte, as relações de SCar com seu retorno, onde são poucas as empresas que utilizam as inovações. Cerca de dez empresas de base tecnológica de São Carlos mantêm escritórios de representação na cidade de São Paulo e em outras cidades do País.

No sentido inverso, aquisição de insumo e matérias-primas, São Carlos afirma mais fortemente o nexo com o Capital: são 20 empresas, 83,3\% do conjunto por nós estudado, que se abastecem em São Paulo, contra somente 3 que adquirem matéria prima em Minas Gerais e outras 3 no Exterior.

O permanente contato com a Capital facilita as relações com clientes e fornecedores.

6 - Em tópico anterior, vimos que São Carlos, desde o século XIX, manteve o alto ritmo de acumulação, não só através da produção agro-exportadora, como também pela via da atividade industrial. Dessa história econômica decorre a presença de pessoas ou famílias com significativa poupança financeira e recursos econômicos em condição de serem transferidos para empreendimentos de risco, como são as empresas que lidam com as chamadas novas tecnologias.

Vinte empresários nos revelaram que os investimentos de suas firmas decorreram de seus próprios recursos. Convém lembrar que os equipamentos de indústria, mesmo de porte reduzido, que lida com inovações tecnológicas são de custo elevado, requerendo, inicialmente bom aporte financeiro.

A exigência de elevado investimento tem levado à associação de algumas pessoas, da mesma família ou profissão semelhante, para criar uma empresa. 
Somente 6 das 24 empresas declararam-se de apenas um proprietário, ao lado de 5 com 2 e 13 com 3 ou mais sócios.

Respondendo à questão da escolha de São Carlos para situar sua firma, nove pequenos empresários apresentaram, como uma das razões importante, a origem da família e o local da residência na Cidade.

7 - Um marcado e importante fator locacional das atividades inovadoras é representado pelas condições sócio-espaciais: ambiente favorecido pela natureza, com clima agradável, belas paisagens, disponibilidade de área de recreação e de lazer, sem os males da poluição e os entraves aos fluxos das pessoas, tão comuns nas grandes aglomerações; tudo isso se valoriza, mais ainda, quando domina outro tipo de clima: o de baixa temperatura e de pressão social que favorece a germinação e a rápida reprodução do capital sem as perturbações das organizações sindicais e acirradas reivindicações dos movimentos populares. É o que algumas pessoas denominam de ambiente tranquilo e pacato para "trabalhar e viver", típico dos tecnopolos em vários lugares do mundo.

São Carlos adiciona mais outros importantes ingredientes nesse cenário sócio-espacial: é uma cidade de bom nível de infra-estrutura local e regional envolvida por uma atmosfera de cultura tecnológica que vem se firmando desde o século passado, conforme dissemos.

Referindo-se a essas qualidades de São Carlos, os empresários utilizam expressões como "tranquilidade da cidade" ou "ambiente saudável".

8 - Um último fator de realce para o surgimento desse tipo de empresa em São Carlos é o que chamaremos de rede informacional que se estabelecera com a fricção internacional de pessoas e de negócios.

Mesmo antes das Universidades em SCar, através dos imigrantes europeus, a influência de hábitos e costumes, a transmigração de alguns valores técnicoeconômicos dos países do Velho Mundo estão registrados não só nos documentos escritos, como também na própria construção do parque industrial, cujas firmas ainda mantêm o convívio com a realidade fora do País.

Com as Universidades, isso se faz na condução das pesquisas, das criações, das inovações, através dos eventos científicos internacionais, de cursos de pósgraduação no estrangeiro, de visitantes, de programas de colaboração e de pesquisa, de viajantes.

Essas duas vias são reforçadas pela utilização de inúmeras publicações de vários países encontradas nas diversas bibliotecas da Cidade. Noutra dimensão, encontram-se os meios da telemática, intensamente utilizados nas duas Universidades que se põem, no dia a dia, familiarizadas com o desenvolvimento das pesquisas e das novas criações no mundo. 
Esses aspectos nos ajudam, talvez, a buscar alguns indícios para explicar a presença, em São Carlos, de tantas inovações tecnológicas (30 em 15 indústrias, em janeiro de 1991) e relações das indústrias (convênios, aquisição e insumos etc) com importantes centros internacionais, como o de Darmstadt, na Alemanha.

\subsection{As relações empresas $x$ universidade e inter-empresas}

A aproximação das empresas com as Universidades fora muito intensificada com os estágios supervisionados de estudantes da área técnica. De algum modo, esse sistema de treinamento originou um entrosamento mais firme entre o saber e o fazer, como consultoria, projetos e convênios. Serve como exemplo clássico a esse desempenho o que fez o Departamento de Engenharia de Materiais (DEMa) da UFSCar, estudado por Rachid (1991).

Algumas organizações funcionam como interfaces no gerenciamento dos projetos e convênios entre empresas e Universidades, destacando-se a FIPAI e a FAFQ.

Em março de 1976 fora criada a Fundação para o Incremento da Pesquisa e do Aperfeiçoamento Industrial - FIPAI -, com a finalidade de propiciar aos Departamentos da Escola de Engenharia de São Carlos e aos demais Institutos do Campus da USP, em São Carlos, uma estrutura mais ágil para a prestação de serviços à comunidade. Por estar desvinculada dos entraves burocráticos de administração pública, a FIPAI é dotada de uma estrutura flexível e dinâmica que lhe permite, rapidamente, a celebração de quaisquer tipos de contratos e/ou convênios. Conforme os dados dos anos 1978-90, a FIPAI desenvolveu um total de 83 projetos, envolvendo empresas públicas e privadas de vários Estados.

A fundação de Apoio à Física e à Química - FAFQ - foi instituída em 28/5/82, como entidade privada, sem fins lucrativos, vinculada ao Instituto de Física e Química de São Carlos, da USP. Entre outros de enorme alcance científico e tecnológico, a FAFQ tem como objetivo o de colaborar, pelos meios adequados, com os Institutos Educacionais, com as Universidades e com as instituições públicas e privadas, em programa de desenvolvimento tecnológico a ser estabelecido em colaboração com a IFQSCar.

De 1985 a 1990, a FAFQ firmou cerca de 43 projetos, envolvendo perto de oitocentos mil dólares, com 26 empresas privadas e 17 empresas e órgãos públicos, destacando-se a Petrobrás, a FINEP, MCT, a Rhodia, Johnson e a Pirelli. Participaram 21 professores de 11 grupos de pesquisa de Química (6) e Física (5).

Em nosso estudo junto a 24 empresas de alta tecnologia de SCar, identificamos 12 que utilizam os laboratórios universitários, 10 que têm consultoria de docentes. Destas últimas, só três não se utilizam também dos laboratórios. Além desses meios, algumas recebem colaboração técnico-científica de estudantes de pós-graduação.

Várias das relações inter-empresas ocorrem na troca de experiências e desenvolvimento de projeto e teste de aparelhos. Quando a empresa sancarlense desenvolve algum equipamento ou processo para as grandes, destas ela recebe especificações técnicas.

Torkomian (1992), ao se referir-se aos tipos de relacionamento entre as empresas de alta tecnologia, verifica que, em 14 casos, 7 desenvolviam projeto conjunto, 5 trocavam informações e 2 transferiam 
tecnologia à Universidade, o relacionamento objetivava absorver tecnologia, informalmente, desenvolver trabalhos complementares, atualizar-se através de curso ou simplesmente testar algum produto ou matéria-prima.

\section{Cidade de São Carlos}

Localização das indústrias de Alta Tecnologia - 1989

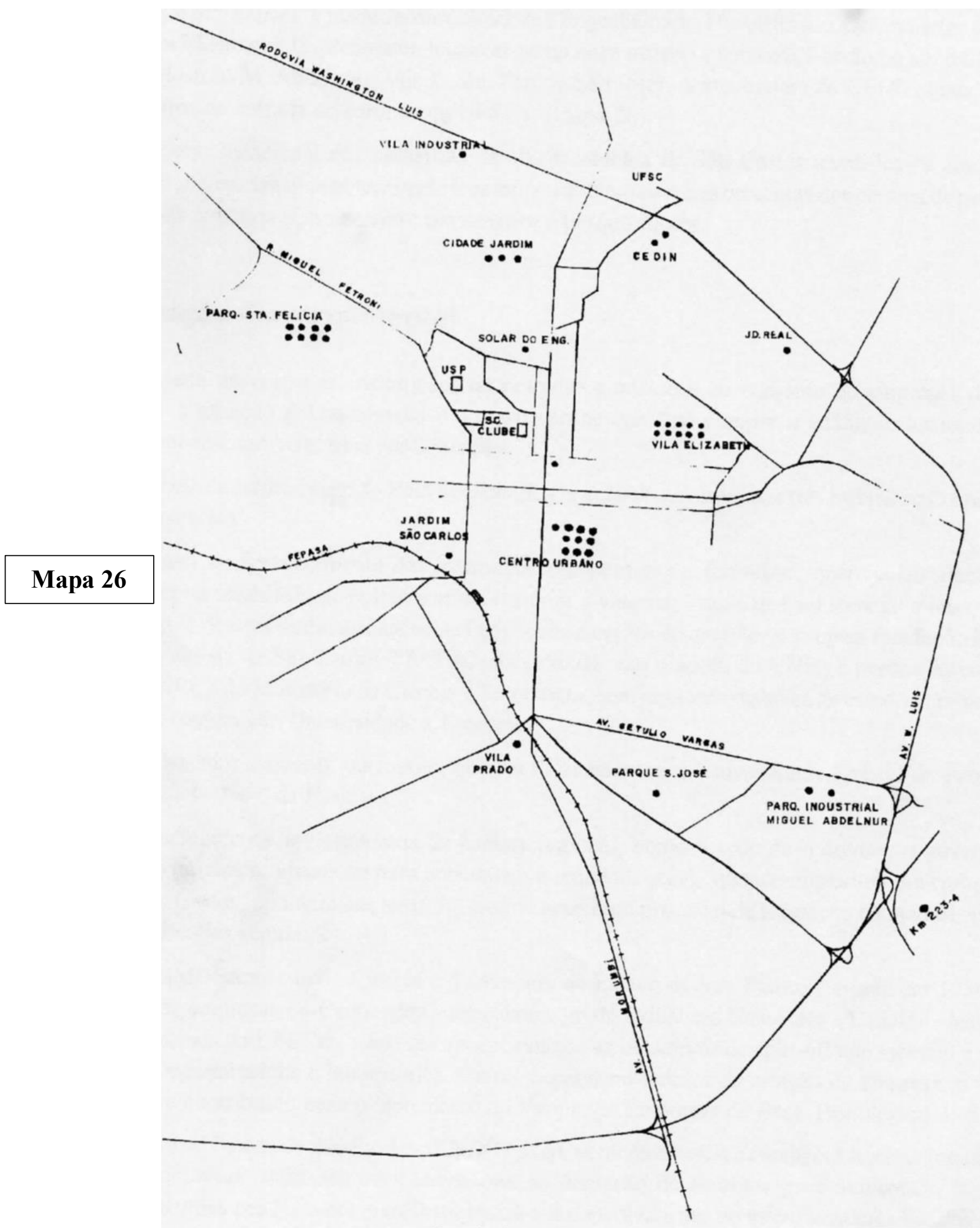

Organizado por Luiz Cruz Lima 
No relacionamento com a Universidade, as empresas utilizam-se de vários canais, detectados em nosso trabalho e por Torkomian (1992): a amizade, estudantes em estágio, professores ou, em menor grau, órgãos de interface. O convívio entre empresas e universidades é muito favorecido pela vizinhança que elas mantêm.

Das empresas de alta tecnologia de São Carlos, cerca de 12 estão na vizinhanças do campus da USP (Parque St ${ }^{\mathrm{a}}$. Felícia, Cidade Jardim, Solar dos Engenheiros), 10 outras são equidistantes dos dois campi (Vila Elizabeth), 12 preferiram localizar-se no core da UFSCar (mapa 26).

O aspecto locacional das indústrias de alta tecnologia de São Carlos identifica-se com o que normalmente ocorre em muitos tecnopolos: as empresas situam-se nas cercanias dos centros de pesquisa, facilitando os contatos pessoais entre empresários e pesquisadores.

\subsection{Atuação Governamental}

Associada ao corpo de instituições de pesquisa e ensino e ao conjunto de empresas de base tecnológica, a atuação governamental é o outro vértice que vem compor o triângulo tecnopolitano. São Carlos aceita, também, essa configuração.

Em termo da estruturação do Pólo Tecnológico, a ação do governo, nas três esferas se faz presente em vários aspectos:

No plano do fortalecimento das instituições de pesquisa e formação, quer na instalação das equipes, quer na concessão de bolsas e apoio material a viagens, é mais que substancial a intervenção federal, através de suas diferentes agências financeiras e órgãos de decisão. A própria Fundação Parque de Alta Tecnologia de São Carlos-FPATSC- fora criada com o apoio do CNPq e passou a receber a ajuda da FINEP e do Ministério de Ciência e Tecnologia, com uma cota de bolsa de estudo para projetos que visam à cooperação Universidade $\mathrm{x}$ Empresa.

Não devemos esquecer, outrossim, que em SCar há uma única Universidade Federal do Estado de São Paulo, e a NapDIA, da Embrapa.

Não incluindo os investimentos de caráter regional, como a rede de rodovias, o governo do Estado deu a partida fundamental para concretizar a realidade atual, quando implantou um campus da USP em São Carlos, no início dos anos 50, e manteve num processo de formação e amadurecimento nas quatro décadas seguintes.

Através da Secretaria de Ciência e Tecnologia do Estado de São Paulo, é criada em 1986 uma incubadora de empresas ou Centro de Desenvolvimento de Indústrias Nascentes CEDIN - instalado próximo à entrada da UFSCar, como que recepcionado as iniciativas de spin-off que viessem a surgir nos vários Departamentos e laboratórios. Como mecanismo indutor de criação de empresa, o CEDIN em muito tem contribuído para o incremento do Parque de Empresas de Base Tecnológica de SCar.

Pioneiro no Estado de São Paulo, o CEDIN de SCar oferece meios e condições básicas (incubação para até 8 empresas, infra-estrutura, assessoria na captação de recursos governamentais, cursos e palestras, estrutura para uso compartilhado) para o desenvolvimento 
de micro negócios ligados à alta tecnologia. É uma iniciativa ímpar do País, nos anos 80. Das 12 empresas já incubadas no CEDIN, só 2 não vingaram por falta de capital.

Como sói acontecer em muitos outros lugares do mundo, em São Carlos o poder público municipal tem sido vital na vivicação das idéias dos professores e empresários que alavancaam o projeto do Parque de Alta Tecnologia.

A Prefeitura foi, junto ao $\mathrm{CNPq}$ e outros órgãos, uma das principais promotoras da Fundação Parque de Alta Tecnologia de São Carlos - FPATSC), criada em fins de 1984, conquistando, assim, assento (com 2 dos 11 membros), no conselho de Curadores. Por não ter sede própria, a Prefeitura arca com as despesas de alocação desse órgão gestor de Pólo Tecnológico. Durante alguns anos, a Prefeitura repassou à FPATSC o ISS (Imposto Sobre Serviços) gerado pelas empresas de alta tecnologia, criadas a partir de 1985.

Uma das ações mais expressiva do poder local, a favor do pólo tecnológico, foi um edital de 17/10/88 estabelecendo "a alienação de lotes de terra destinados à instalação de indústrias no novo Distrito Industrial (DI) de São Carlos, criado pela lei n 9.930m de 15.03.88”.

Esses lotes perfazem uma área útil de 63,2 h., descontadas as áreas de preservação e arruamento, onde será instalado o CENTRO EMPRESARIAL DE ALTA TECNOLOGIA CEAT. Haverá uma parte do D.I. destinada a indústrias tradicionais, com especificações de resguardo à proteção ambiental.

Em três anos - 1988 a 1990 - cerca de 31 empresas adquiriram um total de $377.646,5 \mathrm{~lm}^{2}(37,7 \mathrm{ha})$, como se pode ver na tabela 19 .

Tabela 19

Centro Empresarial de Alta Tecnologia - CEAT

Aquisição de Área - 1988 a 1990

São Carlos

\begin{tabular}{c|c|c|r}
\hline Ano & Empresa & Lotes Adquiridos & \multicolumn{1}{c}{ Área total (m2) } \\
\hline 1988 & 11 & 25 & 88372,31 \\
\hline 1989 & 10 & 50 & 191994,76 \\
\hline 1990 & 10 & 29 & 97279,45 \\
\hline Total & 31 & 104 & $377.646,52$ \\
\hline
\end{tabular}

Fonte: CEAT - D.I. 1991.

Pelo fato de reunir, em seu órgão máximo de administração (Conselho de Curadores), representantes do CNPq, Prefeitura e CIESP (Centro industrial do Estado de São Paulo) da Federação das Indústrias (FIESP), a Fundação Parque da Alta Tecnologia de São Carlos assume importância vital na propulsão do Polo Tecnológico. A fundação instituiu como sua finalidade "criar condições para elevar o grau de interação em Alta Tecnologia entre o SNDCT ( Sistema Nacional de Desenvolvimento de Ciências e Tecnologia) e o setor produtivo" (Artigo $7^{\circ}$ ), detalhada em 10 alíneas.

Outra iniciativa da FPATSC foi a criação do Centro de Inovação Tecnológica de São Carlos - CETESC, como apoio da Prefeitura Municipal, do MEC, MCT e FINEP, O CETESC se volta à formação de recursos humanos em química fina, ciência dos materiais, instrumentação e mecânica de precisão, direcionados às necessidades das indústrias sediadas na região. 


\section{Conclusões}

Muitas são as facies em que encontramos o meio técnico-científico, no campo e na cidade, nos países mais ricos e nos países subdesenvolvidos, nas ecúmenas e no espaço natural.

O que aqui se põe - o tecnopolo - é o que se diz mais requintado, uma das organizações produtivas mais cobiçadas pelas regiões, pelos lugares. É um meio competente em que está impregnado o signo do desenvolvimento, da modernidade, guardando, pois, em si, um aspecto mítico. Dá-lhe esse caráter a condição de agregar elementos virtuais que, em sinergia, conduzem a dinâmica da informação privilegiada, base da globalização que se faz pela interdependência possível dos lugares, por via das redes.

E como os tecnopolos se dão em rede, eles se hierarquizam, segundo seu padrão organizacional e de pesquisa.

No Terceiro Mundo, tomado o Brasil como exemplo estudado, onde há maior decisão de comando externo, forma-se maior densidade técnica. As forças exógenas não eliminam, contudo, a parcela técnica local pré-existente. Pelo contrário, tudo o que constitui elemento agregador faz parte da maionese. A estratégia tomada direciona-se a renovar as formas e estabelecer normas que se adequem as novas funções requeridas pelo modelo agora em execução.

À medida que ocorre a renovação, os ambientes aceitam, acatam o conhecimento racional das ciências e das técnicas, tornando-se um meio técnico-científico. Com a implantação, paralelamente, do sistema informacional, quebram-se as fronteiras. Com essa abertura, os lugares competentes tomam importância no quadro mais amplo da produção e da economia.

A participação de mais atores na elaboração de inovações, produzidas pelo conhecimento científico, amplia as possibilidades da retomada de novo ciclo.

A fase de ascensão de novo ciclo desabrocha em algumas regiões do mundo, contraditoriamente, com perdas para os trabalhadores. Assim, a crise se aguça pelas exigências profundas para modificar o subsistema sócio-institucional até então vigente, ante um novo subsistema tecno-econômico.

As mudanças institucionais e as novas tecnologias em uso têm sido mais favoráveis à bonança das empresas do que à sobrevivência dos menos aquinhoados da sociedade. Em relação à força-de-trabalho mais operativa, as perdas das conquistas sociais se ampliaram de tal modo que parte significativa da massa de trabalhadores, nos países com modelos neoliberais, situa-se na condição de "burn-out", perdida num vazio econômico e social.

Ademais, aumentam as exigências pela elevação da produtividade, dada a intensificação da luta competitiva inter-empresarial e entre os países, mediada pelos Estados.

Com a corrida competitiva, apela-se, mais e mais, para a fonte criativa das inovações (a terceira fonte de que falamos no item 2.2, na p.32), dando respaldo à "perversão da ciência".

Por meio das telecomunicações, formam-se redes mais amplas de empresas, dentro da cadeia de mercadorias, verificando-se dois tipos de resposta: 
1 - maior flexibilidade na utilização de centros especializados (ou mesmo na definição de melhores localizações para atividades especializadas) e

2 - remanejamento dos quadros mais qualificados para áreas onde possam ter maior desempenho ou substituição dos não-remanejáveis, aos quais se incluem pessoas desatualizadas, força-de-trabalho de custo mais elevado no local de origem, os trabalhadores de idade mais avançada e, enfim, todos aqueles que não atendam às imposições do novo modo de produção.

Em termo de espaço geográfico, o reordenamento da produção se exterioriza nos padrões espaciais:

$1^{\circ}$ ) seletividade dos centros urbanos, em função dos equipamentos pré-existentes e da absorção de um ambiente inovador;

$2^{\circ}$ ) novas formas se estabelecem para as funções, antes inexistentes, como é o caso dos smarts buildings;

$3^{\circ}$ ) os "vales do silício" se expandem pelo mundo, recriando ou renovando economias de aglomeração;

$4^{\circ}$ ) as definições regionais não se dão somente por contiguidade, mas também por vetores cuja dimensão e espessura variam com os fluxos;

$5^{\circ}$ ) convocação dos espaços virtuais na formação do "exército de reserva" de lugares priveligiados;

$6^{\circ}$ ) em sentido inverso, rebaixamento de certas funções e formas do circuito supetior para o circuito inferior da economia urbana, no caso do Terceiro Mundo. Em alguns casos, tornam-se essas funções inúteis, desagregam-se e desaparecem.

À escala local e regional, o mercado de trabalho se polariza: os mais qualificados se estabelecem em bairros ou em cidades-dormitórios, distanciados dos aglomerados de moradias dos trabalhadores braçais e dos burn-outs que vivem segregados em ambientes de miséria.

A seletividade espacial se conjuga á especulação imobiliária, comum neste tipo de meio técnico-científico, porquanto o valor do espaço se eleva com a implantação de valor no espaço representado pelo ambiente inovador, que sorve elevados investimentos públicos e privados.

Reforçam a valoração do espaço as novas configurações dos distritos industriais que se implantam nas vizinhanças da vantagem comparativa mais significativa: os centros de pesquisa, laboratórios, universidades.

No contexto desse mesmo fluxo, com a flexibilidade nas linhas de produção das firmas maiores surgem pequenas empresas como uma multiplicação em cissiparidade, o que em alguns casos dá origem a nichos de mercado, amplia os pequenos negócios que mais facilmente absorvem inovações porque reduzem os riscos, além de fecundarem um processo de especialização.

Toda a efervescência de expansão territorial resulta na elevação da economia externa com spin-offs, com a ampliação do núcleo terciário e elitizando o ambiente com sofisticados serviços e renovação, por conta do poder público, de parte do quadro urbano onde se cria centro especializado do setor quaternário (ou terciário superior), como tem ocorrido em várias grandes cidades. Em certos casos, nesses ambientes urbanos renovados instalam-se tecnopolos, como em Berlim.

Sem a participação efetiva do Estado, em todas as instâncias, essas condições não se viabilizariam. 
Ele não é apenas o executor, mas também o mediador das ações, de propulsão da massa de demanda. O saldo pode ser visualizado na paisagem urbana, no espaço regional, nos novos comportamentos sociais e na adesão da sociedade local ao circuito da divisão internacional do trabalho.

Efetiva-se com a dinâmica empresarial e os investimentos públicos, desenvolvimento local e regional, pelo menos onde essas possibilidades são satisfeitas.

A corrida à competitividade, com a crise dos anos 70, impôs às empresas também a necessidade de remodelarem a estrutura interna e redefinirem novos padrões locacionais, daí resultando:

$1^{\circ}$ ) deslocamento ou redução das grandes plantas industriais, sucateando espaços tradicionalmente fabris;

$2^{\circ}$ ) ressurgência de novos espaços industriais, com unidades mais selecionadas, do ponto de vista de proteção ao meio ambiente;

$3^{\circ}$ ) reaproximação dos concorrentes com a compra-venda de empresas ou formação de consórcios de empresas para aproveitar certas externalidades e estabelecer cooperações mútuas;

$4^{\circ}$ ) reodernamento territorial urbano quanto regional, levando em consideração a presença dos equipamentos favoráveis à melhoria da produção, assim como fluxos de informações e de pessoas;

$5^{\circ}$ ) a criação dos espaços técnicos-produtivos ou tecnopolos, quando há aproximação física e funcional com as Universidades;

$6^{\circ}$ ) formação de pequenas firmas decorrentes da desintegração vertical, mas integradas na "rede de mercadorias" gerenciada pela grande empresa.

O desenvolvimento de empresas high-techs de pequeno porte fica muito dependente, não apenas da grande empresa que domina a linha de produção, como também do capital financeiro, cujos riscos neste tipo de investimento nem sempre ficam minimizados. Nesse caso, os pólos técnico-científicos têm ligação umbilical com os centros financeiros.

Dada a pequena quantidade de centros de excelência em pesquisa, o conjunto de tecnopolos torna-se mais reduzido ainda quando são definidos pela qualidade de pesquisas e seus resultados. Em consequência, os centros de alta qualificação, num processo de filtragem, tendem a selecionar as atividades produtivas em sua proximidade, atingindo um ponto de especialização, comum nas áreas das novas tecnologias.

Ao especializarem-se, num ou em poucos ramos de alta tecnologia, as grandes Universidades, em casos vários, agregam unidades produtivas no seu Campus, formando um típico science park. Com a nova função, essas Universidades têm respondido, de modo positivo, aos projetos de desenvolvimento local e regional, induzindo a criação de novas empresas e fortalecendo as vantagens comparativas locais.

O sucesso na montagem do tecnopolo em muito depende da mobilização das forças sociais, políticas e econômicas por um período de média duração, variando de lugar para lugar.

O tecnopolo, então formado, serve como força centrípeta para os capitais que tendem a se deslocar em busca de melhores e seguras alocações nos mais diferentes recantos do mundo. Nesse aspecto, o tecnopolo assume papel de crescimento e desenvolvimento local e regional. 
A territorialização das reservas técnico-científicas inicia-se com a instalação de organismos do tipo incubadora e PMEs que mantenham vínculos permanentes, diretos ou indiretos, com as unidades de pesquisa, institutos ou Universidades.

As vinculações das instituições de ensino e pesquisa com os pequenos negócios, criados e disseminados no entorno, formam um vetor de ampliação e complexidade da divisão social do trabalho, a medida que se afirma o mercado de mão-de-bra especializada local.

Formada a rede diversificada de produtores, ampliam-se as economias externas, fator de fertilização de mais empreendimentos, com grande evidência de serviços, do mais simples ao mais complexo. Por via das indústrias de alta tecnologia que se desenvolvem nos tecnopolos, os valores terciários invadem a vida econômica como funções intermediárias para haver sistematização e racionalização, com o fim de assegurar a produção e a vida.

Os meios e vias de comunicação expressam-se como fatores locacionais, principalmente quando interligam o local do tecnopolo com aglomerações, centros de decisão e outras localidades complementares à estrutura tecnopolitana. A importância desses equipamentos é proporcional à sua eficiência, como marketing ao lugar, por torná-lo acessível ao mundo, via satélite. Nesse caso, o equipamento mais eficiente, do sistema de informação a longo alcance, atualmente, é o teleporto. Além de ser propiciador de alto volume de transmissão e recepção de informações, ele também promove implantação de infra-estrutura imobiliária para a instalação da rede de serviços na região, para atender a empresários e comunidades.

Os meios rápidos e eficientes de comunicação favoreceram a decomposição de certos setores da produção. Desse fracionamento, por sua vez, resultaram externalidades com as empresas de serviços (terciário superior) que funcionam como adesivos na recomposição dos setores desintegrados. Tais empresas (designs, consultoria, tele-informações etc.) estão muito integradas às indústrias de alta tecnologia que dão novo estilo arquitetônico à paisagem urbana.

Além de redefinir formas, a dinâmica tecnopolitana desarticula as velhas funções, à medida que desmonta a cultura local e, em seu lugar, afeiçoam-se novos modos de ver, de sentir, de valorizar o que se firma com os interesses do que se tem como moderno.

A rapidez das mudanças deixa à deriva as normas das relações de trabalho. No corte temporal-transição entre o fordismo e flexibilidade - procuram-se encaixar as tendências neoliberais que agravam a bipolarização do trabalho não apenas em relação à sociedade, mas também na organização do espaço.

A configuração sócio-espacial resultante tem como invólucro uma atmosfera cultural constituída de particupulas transnacionais condensada num lugar. Assim, tal condensação cria o lugar-mundo, isto é, lugar prenhe das qualidades, dos valores e das forças capazes de responder às necessidades da realidade de modo de produção atual.

Ao mesmo tempo que o tecnopolo, enquanto lugar-mundo, nos conduz às dimensões do porvir, ele também entroniza aspectos do mito da cidade ideal, imaginada na Renascença: domínio do refinamento do saber científico e artístico; coexistência do paraíso das técnicas que possibilitam ao homem a felicidade de ter o monopólio da natureza; identificação dos círculos do conhecimento operativo; divisão dos homens pelo trabalho mecânico e intelectual e inversão do econômico e do social pela técnica.

Por outro lado, nem sempre as criações, as invenções, as inovações nesse ambiente de idolatria 
às técnicas são vistas como resposta às necessidades da maioria, como testemunhou o personagem Gulliver: a cidade científica passa a ser uma alienação, criação de um mundo de poucos, distante do interesse maior da sociedade, transfiguração do enlevo de uma aristocracia em gastos sociais inócuos e sem proveito para a população.

O tempo, contudo, nos pôs frente ao reino do conhecimento técnico-científico e já não podemos titubear como Fausto: "devo eu recear-te, oh! Figura infernal?". Na busca constante do "novo" do "perfeito", essa "figura infernal", essa "figura infernal" é indispensável e se impõe a nos dizer na voz de Mefistófeles:

"Da vida, o que há melhor, cansaste de provar?

E o que há de alegrar, agora, a tua existência?

É sempre muito bom fazer uma experiência

E outras novidades doces procurar"

(FAUSTO, Göethe) 


\section{Abstract}

The presente work attempts to make an analysis o fone the features concerning the technical scientific and informational environment, which is a spinning off of the processo $f$ change through which the world is going through in the last three decades of the century. This is the thickening to a great level or extent of knowledge ando $f$ knowing how to do, the lessening of the distance between desing and plant, which followed organizational patterns demanded by technological innovations, the defining elemento of this novel technicaleconomical paradigma, one that opens a new rising period of capitalistic accumulation. In order to attain this threshold a variety of agentes have intermingled in synergies: universities, governments, financing capital and corporations.

The emergence of industrial and servisse clusters sprouting around enviroments having all facilities related to top-ranking technical-scientifical sites has been fundamental to the establishing of a special kind of spacial organization that we have termed technopole. Initially, technopoles were a feature of first world countries but nowadays the are elso to be found in third world countries. These techonopoles have proved to be a tool for reshaping the productive system organization and consequently, of the very geographical space.

The technopole by the same way that it leads a place into globalization, it reduces the place into fragmentation, as time goes by, it follows the tracks to specialization in some section of hight-tech.

This phenomenon is linked to the capitalistic drive, since the 1970's with the fordista accumulation general crises on, searching fow new means which would be able to hoist productivity and conquer again the markets and the high profits. To start once again the upsurge of growth together with the technological innovations - informatics, brand-new materials, bio-technology and so forth - new rules should be imposed upon society: the restructuring of production relationships and word schedules, the opening of national borders, the institutionalization of neoliberal rules. As much as it is beneficial to corporations, this new (dis)order has spawned a negative surge of ill-effects upon the huge mass of lesser skilled workers, which are more excluded and segregated.

Since the 80's Brazil has been inserted in the fabric of technopole drive, this happens at least in those centers where it is more common the joint-ventures of research and the productive sector. As a case in point we have chosen São Carlos, in São Paulo State country side, for a more detailed study.

The geographical space in several countries and regions bears out already the marks of the technopoles' phenomenon whether it may be in its spatiality or with the cropping upo $f$ regions such as the Silicon Valey (USA) or in the urban shaping upo f scientific cities, the technopoles. 


\section{$\underline{\text { Bibliografia }}$}

ABE, H, ALDEN. J.D. - Regional Development planning in Japan. Regional Studies. Oxford. v.32, n. 5, p. 429-438, 1988.

ALMEIDA, Rômulo. Nordeste: desenvolvimento social e industrialização. São Paulo: Paz e terra, 1985, 286p.

ALTA TECNOLOGIA JORNAL. São Carlos: Fundação de Alta Tecnologia de São Carlos, n. 5-8, 1991.

AMANO, Ikuo. O dilema da educação japonesa hoje. Caderno de cultura japonesa hoje. São Paulo, /s.n/s.p/1986.

ANDERSON, Ian. Silicon Valley teach-in for the French. New Scientist. London, v.101, n. 1004, p.22, Apr. 1984.

ANTOSSIAK, A.B. et al. Geografia do militarismo. Trad. De José Manuel Milhazes Pinto.Moscou: Ed. Progresso, 1987, 222p. Trad. Do original russo.

AQUINO, Rubia Santos Leão de et al. História das sociedades: das sociedades atuais. Rio de Janeiro;Ao livro Técnico. 1983. 376p.

ARAÚJO, Telmo Silva de. Desafios do Parque Técnológico. In: Simpósio Nacional de Pesquisa de Administração em Ciências e tecnologia, 16, 1991. Rio de Janeiro. Anais...Rio de Janeiro: USP/FEA/PACTo, 1991, v.2, p. G.40-45.

AYDALOT, Philippe, KEEBLE, David. High-technology industry and innovative environments: the european experience. London: GREMI/Routledge, 1988, $241 \mathrm{p}$.

BACON, Francis. Nova Atlântida. Tradução de José Aluysio Reis de Andrade. São Paulo: Abril Cultural 1979. 40p. Tradução de "New Atlantis".

BAKIS, Henry. Technopôle, Téléports, Téléparcs, Télébases, Télécommucations et sites à équiper. In: Villes et technopoles-nouvelle Urbanisation, nouvelle industrialisation. Toulouse: Presses Universitaires du Mirail/Université de Toulouse. 1990, p. 377-389.

BECATTINI G. District marshallien: une notion sócio-economique. In: BENKO, G., LIPIETZ, A. Les Régions qui gagnent. Paris: PUF, p.35-55. 1992.

BECKER, Bertha K., EGLER, Cláudio A.G., BARTHOLO, Jr, Roberto. O embrião do projeto geopolítico da modernidade no Brasil: o vale da Paraíba e suas ramificações, Rio de Janeiro: UFRJO/Departamento de geografia/Laboratório de Gestão Territorial. 1988. 25p.

BENKO, Georges B. Geographie de technopoles. Paris: Masson, 1991-a 223p.

Espace industriel, logique de localisation et developpement regional. Espaces et Sociétés. Paris, n.66/67, mar/avr. p.129-146, 1991-b.

BERLIN Centre for Innovation and New Enterprises Tecnology and Innovation Park Berlin. Berlin, 1985. 48p.

BERNAL, John D. La ciência em la historia. Mexico: Editorial Nueva Imagen/UNAM, $1986.694 \mathrm{p}$. 
BIONDI, Gennaro, COPPOLA, Pasquale. Technopole et mezzagiorno d'Itale de la mode à une statégie plus realiste. In: Villes et technopoles nouvelle industrialisation. Toulouse: Presses universitaires du Mirail/Université de Toulouse. 1990. P.147-163.

BOISGONTIER, Pierre, BERNARDY, Michel de Une, deux, trois... petites ZIRST et puis ça va. Autrement: Technopolis, I'explosion des cités scientifiques: USA- Japon-Europe, Paris, n. 74, p. 136-139, nov. 1985.

- Une double personnalité: locale et internationale. Autrement: Technopolis, 1' explosion de cités scientifiques: USA-Japon-Europe, Paris, n. 74, p. 201-202, nov. 1985.

BRAVERMAN, Harry. Trabalho e capital monopolista: a degradação do trabalho no século XX. Rio de Janeiro: Ed. Guanabara, 1987. 379 p.

BRIOLE, A, LAURAIRE, R. Technopoles, teleports: Les nouveux enjeux. NETCON, Toulouse, v.4, n.2,p.359-379 juin, 1990.

BRISOLLA, Sandra de Negraes, PINTO, Luzia A. C. Guedes. A fibra dos físicos na organização da pesquisa na UNICAMP. In: Simpósio Nacional de Pesquisa de Administração em Ciência e Tecnologia, 16, 1991, Rio de Janeiro.Anais...Rio de Janeiro: USP/FEA/PACTo- 1991 p. F. 185-208.

BROABENT, Jeffrey. Technopoles et aménagement du territoire au Japon. Les Annales de la Recherche Urbaine, Paris, n. 46, p. 57-64 mars-avr. 1990.

BRUHAT, Thierry. Vingt technopoles, un premier bilan. Paris: Datar, 1990. 214p.

CAMPANELlA, Tomasso. A cidade do sol. Tradução de Aristides Lobo Rio de Janeiro: Ed. De Ouro, 1976 153p. Título original: Cívita sóis.

CANO, Wilson. Reflexões sobre o Brasil e a nova (des)ordem internacional. Campinas: UNICAMP, 1993. 1884p.

CARROUE, Laurent. Recomposition economique, tissu industriel e dynamique social. Les activités de négoce dans le industries informatiques, eléctriques et electroniques (IEE) em Ile-de-France. In: Villes et technopoles: nouvelle industrialisation, nouvelle urbanisation. Toulouse: Presse Universitaires du Mirail/Université de Toulouse, 1990, p.171-180.

CARTIER, Anne, KERORGUEN, Yan de. Technopoles, état des lieux. Autrement: Technopolis, l'explosion des cités scientifiques: USA-Japon-Europe. Paris, n.74, p.42-54, nov. 1985.

CASTELLS, Manuel. Mudança tecnológica, reestruturação econômica e a nova divisão espacial do trabalho. Espaço \& Debates. São Paulo, n. 17, p. 5-23. 1985.

CERTAINES, Jacques de. La fièvre des technopole. Paris: Syros Alternatives, 1988, 273p.

CHANARON, J.J, PERRIN, J., RUFFIEUX, B. A propôs de l' efficacité des technopôles: quelques enseignements à partir d' exemples français,, In: Villes et technopoles: nouvelle industrialisation, nouvelle urbanisation. Toulouse:, 1990, p.57-71.

CHANCEL, Jules. Heriot - Watt: la nouvelle alma mateer. Autrement: technopolis, I'explosion des cités scientifiques: USA-Japon-Europe, Paris, n. 74, p. 112-118. nov.

(LA) CONTRIBUITION des universités et établissements de recherche aux Parcs Scientifiques et. 
Centres d'Innovation. In: Conference Science Parks and Innovation Centres, 1985, Berlin. Anais...Berlin, :/s.n/1985, p.425-427.

CORREAA, Roberto Lobato. Contribuição ao estado do papel dirigente das metrópoles brasileiras. Revista Brasileira de Geografia. Rio de Janeiro, v.30, n.2 p. 56-87, abr/jun.1968.

COSTA, Wanderley Meessias. O processo contemporâneo de industrialização: um estudo sobre a expansão da produção industrial em território paulista. São Paulo: USP, 1982. 217p. Dissertação (mestrado em geografia). Faculdade de Filosofia, Letras e Ciência Humanas, Universidade de São Paulo, 1982.

COUVIDAT, Yann, GIUSTI, Julien. Atlas international des technopoles. Paris: Syros Alternatives, 1991. 237p.

COUVIDAT, Yann. Vingt aux de gestation trente te maturité em Californie. Les Annales de la Recherche Urbaine, Paris, n. 46, p,31-38, mars/avr. 1990.

CRISTOVÃO, Assunção. A casa do Pinhal. Veja no Interior de SP, ano 23, n. 39,p-1415,out. 1990.

CURRIE, Jean. Science Parks in Britain: their role for the late 1980's. Cardif: CSP economic publications. 1985. 105p.

DAGNINO, Renato Peixoto. Indústria de armamentos: O Estado e a tecnologia. Revista Brasileira de Tecnologia, Brasília. V.14, n. 3, p.3-17, maio/jun, 1983.

DARRIGOL, Oliver. A l'origine de la Silicon Valey, il y avait um rêve. Autrement: Technopolis, l'explosion de cités scientifiques: USA-Japon-Europe, Paris, n.74, p.37-39, nov.1985.

DAVIDOVICH, Fany Rachel. Indústria. In: GEOGRAFIA DO BRASIL. Rio de Janeiro: IBGE, 1997.v.3,p.485-567.

DE BRESSON, Christian. Les poles technologiques du developpment: vers um concept opérationel. Revue Tiers Monde, Paris, t. 30, n. 118, p.245-270, avr./juin, 1989.

DELMAS, Philippe. De la difficuté d'être petit. Autrement: Technopolis- 1' explosion de cités scientifiques: USA-Japon-Europe, Paris, n. 74, p.203-209, nov. 1985.

DERIAN, Jean-Claude. La haute technologie américaine: ressort et strategies. Futuribles. Paris, n. 112, p. 47-81, juil-aout, 1987-b.

. La haute technologie americaine en déclin? Futuribles. Paris, n. 111, p. 3-25, juin, 1987.a.

DEVESCOVI, Regina C. Baliero. Urbanização e acumulação: um estudo sobre a cidade de São Carlos. São Carlos: UFSCar/Arquivo de História Contemporânea, 1987, 265p.

DEZERT, Bernard. Technoparcs et technopoles. Revue Belge de Geographie, Bruxelas, t. 116, p. 209-215p, 1992.

DIANI, Marco. Turin: de monopolville a technocity. Autrement: Technopolis, l'explosion des cités scientifiques: USP-Japon-Europe, Paris n.74, p.120-125, nov. 1985p.

DIXON, Bernard. Para que serve a ciência? São Paulo: Ed. Nacional: USP, 1976, 245p. 
DOLLFUS, Oliver, Le systéme monde. L' Information Geografique, Paris, n. 54, p. 45-52, marsavr, 1990.

DOMMERGUES, Pierre. De' l'individualisme suavage à la concertation douce. Autrement: Technopolis, l'explosion des cités scientifiques: EUA-Japon-Europe. Paris, n. 74, p.5566, nov. 1985.

DORFMAN, Nancy S. Route 128: the development of regional high techonology economy. Researach Policy, North-Holland, n. 12, p. 299-316 dec. 1983.

DREULLE, Sylvie, JALABERT, Guy. La technopole toulousaine: le développment de la Vallée de 1'Hers. L'Espace Geographique, Paris, n. 1 p. 15-29, 1987.

DURAND, Marie-Françoise, LÉVY, Jacques, RETAILLÉ, Denis. Le monde, espaces et systèmes. Paris: Presses de la Fondation Nationale de Sciences Politiques \& Dalloz. 1992 $564 p$.

ELLUL, Jaques. A técnica e o desafio do século. Rio de Janeiro: Paz e Terra, 1968, 445.p. Mudar de revolução: O inelutável proletário. Rio de Janeiro: Ed. Rocco, 1985, 280 p.

ELSON, John. Campos of the future. Time international. New York, n. 15, p-38-42, 13 apr,.1992.

FARAMOND,Guy. "Maison de l'innovation" et parcs scientifiques. Autrement: Technopolis, 1'explosion des cités scientifiques: USA-Japon-Europe. Paris, n. 74, p. 133, p. 21-34, juin, 1989.

FEDERAÇÃO DAS INDÚSTRIAS DO ESTADO DE SÃO PAULO. Centro de informações do Estado de São Paulo. Sistema de informação municipal: São Carlos e região de governo. ( Dados de 1987).

FONSECA, Mário. Rio mostra receita de consórcio. Dados e Idéias, São Paulo, v.12, n.108, p.20, jul. 1987.

FOURASTIÉ, Jean et Jacqueline. La rués tertiaire. Futuribles, Paris, n. 133, p 21-34, juin, 1989.

FUJITA, Kuniko. The technopolis: High tecnology and regional development in Japon. International jornal of Urban and Regional Research, Essex, v. 12, n. 4, p. 467-593, 1988.

FUNDAÇÃO DE APOIO À FÍSICA E À QUÍMICA. Relatório anual. 1989. São Carlos, 1990. $18 \mathrm{p}$.

FUNDAÇÃO PARA O INCREMENTO DA PESQUISA E DO APERFEIÇOAMENTO INDUSTRIAL. Relatório dos projetos de 1978-1990. São Carlos. 1990. 16p,

FURLANETTO, Diva Almeida. Indústria. In: GEOGRAFIA do Brasil. Rio de Janeiro: IBGE. 1990. v.2, p.261-293.

GADREY, Jean. De la valeur des services. Futuribles. Paris, n. 128/29, p.3-13, fev-mar. 1989.

GALBRAITH, John Kenneth. O novo Estado Industrial. Rio de Janeiro: Civilização Brasileira. 1969, 456p.

GEOGRAFIA ILUSTRADA, Brasil: Guanabara. São Paulo: Abril Cultural, n.2, 1971. 20p. 
GIBB, John -Michel. Vers une coopération européenne. Autrement: Technopolis, l'explosion des cités scientifiques- USA-Japon-Europe. Paris n. 74, p. 104-107. Nov. 1985.

GILLY, J.P. Innovation et territoire: pour une approche méso-analytique des technopoles, In: Villes et technopoles: nouvelle industrialisation, nouvelle urbanisation. Toulouse: Presses Universitaires du Mirail/Université de Toulouse, 1990, p-105-111.

GLASMEIER, Any K. The japonese technopolis programme: high-tech development strategy or industrial policy in disguici? International Journal of Urban and Regional Research, Essex, v.12, n.2, p.268-284, jun, 1988.

GORZ, André. Adeus ao proletariado: para além do socialismo. Rio de Janeiro: Forenseuniversitária, 1982. 236p.

HARRIS, Chauny D. The urban and industrial transformation of Japan. The Geographical Review /s.1/ v.72, n. 1, p.50-89, 1982.

(THE) Housing and Urban Development Corporation. Tsukuba Science City, Tsukuba, 1990, 24p.

HOWELLS, J.R.L. The location of research and development: some observations and evidence from Britain. Regional Studies, Oxford. G.B. v. 18, n. 1,p.13-29, 1984.

INFORMATIVO UAPDIA, São Carlos: UAPDIA/EMBRAPA, N. 1, Jan-jul, 1986, n. 2, juldez, 1986, n.3, jan-jun, 1987, n. 5, jan-jun, 1988, n. 6, jul-dez, 1989, n. 7, jan-jun, 1990.

INNIS, Edgar MC. História da II Guerra Mundial. Rio de Janeiro: Globo, 1949, v.6.

(LES) Investissements Japonais dans le mond. Futuribles, Paris, n. 132 p. 49-57, juin, 1989.

ISHIHARA, Shintaro. O Japão que sabe dizer não. São Paulo: Siliciana. 1991. 157p.

JALABERT, Guy. GRÉGORIS, Maité. Turin: de la ville-usine à la technopole. Annales de Géographie, Paris, n 538, p.680-703, nov/dez, 1987.

JALABERT, Guy. Villes et techopoles, mythes et realités. In: Villes et technopoles: nouvelle industrialisation, nouvelle urbanisation. Toulouse: Presses universitaires du Mirail/Université de Toulouse, 1990, p.21-31.

JOIA, Paulo Roberto. A estruturação do pólo tecnológico de Campinas: contribuição ao estudo dos espaços industriais de alta tecnologia. Rio Claro: Universidade Estadual Paulista Júlio Mesquita Filho, 1992. 147p. Dissertação (mestrado em Geografia). Instituto de Geociências e Ciências Exatas, Universidade Estadual Júlio Mesquita Filho, 1992.

JORNAL DA FEDERAÇÃO DE SÃO CARLOS, São Carlos: UFDSCar, set. 1989, maio 1990, jun. 1990, jul 1990, set 1990, nov 1990.

KESTELOOT, Christian. L'organisation spatiale de la croissance industrielle au Japon: 19681990. Revue Belge de Geographie, Bruxelas n. 114, p. 41-59, 1990.

KONDRATIEFF, Nicolai D, GARVY, George. Las ondas largas de la economia. Revista de Occidente, Madrid, 1946. 123p.

LAZDUNSKI, Michel. Sciences et Technologies de la santé. Le Journal de Sophia Antipolis. Valbonne, n.2, p.17, sept.1990. 
LEME, Ruy Aguiar da Silva. Contribuições à teoria da localização industrial. São Paulo: Instituto de Pesquisas Econômicas. USP/FEA/IPEA, 1982. 378p.

LEVINSON, Adrian Ricardo, MEDEIROS, José Adelino. Apoio ao desenvolvimento tecnológico: núcleos de inovação, incubadoras e parques. In: Simpósio Nacional de Pesquisa de Administração em Ciência e Tecnologia 13, 1988 São Paulo. Anais... São Paulo: USP/FEA/PACTo, 1988,p.1061-1074.

LEVY, Jean-Paul. Dèveloppment industrial et croissance urbaine aux Etat-Unis: l'exemple Californien de Silicon Valey. L'Information Geographique, Paris, v.50. n. 4, p.133140. 1986.

- Les industries de pointe aux Etats-Unis. In: Villes et techonopoles: nouvelle urbanisation, nouvelle industrialisation. Toulouse: Presses Universitaires $\mathrm{du}$ Mirail/Université de Toulouse 1990. p.251-260.

LIMA, Marcelo Alceu Amoroso, FERRO, J. Roberto, TORKOMIAN, Ana Lúcia Vitale. O Pólo industrial de alta tecnologia de São Carlos. São Carlos, 1987. 36p,

LIMA, Olga M.Buarque de , CORRÊA, Roberto Lobato, Sistema urbano. In: Geografia do Brasil. Rio de Janeiro: IBGE, 1977, v.3,p.569-661.

LIPIETZ, Alain. Miragens e milagres: problemas da industrialização do Terceiro Mundo. Tradução de Catherine Marie Mathieu. São Paulo: Nobel, 1987. 231p. Título original: Mirages et miracles-probleme de l'industrialisation dans le Tiers Monde.

LIPIETZ, Alain, LEBORGNE, Danièle. O pós-fordismo e seu espaço. Espaço \& Debate, São Paulo, v.8, n. 25, p.12-29, 1988.

LORENZO, Helena Carvalho de. Origem e crescimento da indústria na Região de Araraquara - São Carlos(1990-1970). São Pauo: USP. 1979. 180p. Dissertação (mestrado em história). Faculdade de Filosofia, Letras e Ciências Humanas. Universidade de São Paulo, 1979.

MALECKI, Edward J. Locational trends in R x D by large US corporations, 196-77, Economic Geography, Massachusetts, p.209 - 323, oct., 1979.

. Dimensions of R x D location in the United States. Research Policy, North Holand, v.9, p.2-22, 1980.

. Corporate organisation of $\mathrm{R}$ and $\mathrm{D}$ and location of technological activities. Regional Studies, Oxford, G.B. v. 14, p.219-234, 1980-b.

Federal R and D spending in the USA: some impacts on metropolitan economics Regional Studies, Oxford, G.B. v. 16, n. 1 p. 19-35, 1982.

MAMIGONIAN, Armen. O processo de industrialização de São Paulo. Boletim Paulista de Geografia, São Paulo, n. 50, p. 83-102, 1976.

MANDEL, Ernest. Ensayos sobre el neocapitalismo. Traduccíon: Carlos Sevilla. México: Edliciones Era, 1971. 263p.

O capitalismo tardio. Tradução de Carlos Eduardo Silveira Matos, Régis de Castro Andrade e Dinah de Abreu Azevedo. São Paulo: Abril Cultural, 1985. 417p. Título original. Der Spaetkapitalismus Versuch einer narxistischen Erklaerung. 
Crise econômica mundial: origens e perspectivas. Conferência na FEA/PUC- SP. 10/03/88. (Mimeografado).

MANGAZOL, Claude. Genèse d'um coplexe technologique: 1 ecas de Phoenix. In: Ville et technopoles: nouvelle urbanisation, nouvelle industrialisation, Toulouse: Pesses Universitaires du Mirail/Université de Toulouse, 1990-a. p.265-282.

. Les technopoles, variétés des formes similitudes des processos. In: Villes et technopoles nouvelle urbanisation, nouvelle industrialisation, Toulouse: Presses Universitaires du Mirail/Université de Toulouse, 1990-b. p.141-145.

MARCOVITH, Jacques. O panorama latino-americano de ciência e tecnologia. In: Seminário Internacional Parques Tecnológicos, 1987, Rio de Janeiro. Anais... Rio de Janeiro: COPPE, CNPq, 1987, p.67-72.

MARKUSEN, Ann Roell e BLOCH, Robin. Deffensivve cities: military spending high technology and human settlements: In: Castells, M. "High Technology, space and Society”. Beverly Hills: Sage Publications, 1985, p. 106-120.

MARSHALL, Alfred. Princípios de economia. Tradução de Rômulo Almeida e Ottolmy Strauch . São Paulo: Abril Cultural, 1985, v.1. Título original: Principles of Economies An introdutory volume.

MARX, Karl. O capital - crítica da economia política. Tradução de Reginaldo Sant' Anna. Rio de Janeiro: Civilização Brasileira S.A, 1970, v.3. Título original: Das Kaptilial.

MATHIEU, Jean-Louis, MESOLIER, Alain. Géographie de la France. Paris: Hachette, $1986.251 \mathrm{p}$.

MEDEIROS, José Adelino, STAL, Eva, SOUZA NETO, J. Adeodato. A difícil relação pesquisa- produção: experiência brasileira dos núcleos de inovação tecnológica. In: Simpósio Sobre Gestão Tecnológica, 1, 1987, P. 85-101.

MEDEIROS, José Adelino, Parques tecnológicos: a experiência britânica e repercussões no Brasil. In: Simpósio Nacional de Pesquisa de Administração em Ciência e Tecnologia, 13, 1988. São Paulo Anais... São Paulo: FINEP/USP, 1988.

MEDEIROS, J. Adelino, Eva, MATTEDI, A. Prest et al. Perfil dos pólos tecnológicos brasileiros. Brasília: CNPq/IBCT/SENAI... 1992. 59 p

MEDEIROS, J. Adelino, MEDEIROS, Lucília Atas, MARTINS, Thereza et al. Pólos, parques e incubadoras. Brasília: SCT/CNPq/IBICT/SENAI. 1992-b. 310p.

MERLANT, Philippe. Au commencement était le verbe. Autrement: Technolopis, 1'explosion de cités scientifiques: USA- Japon-Europe. Pari, n.74, p.20-24, nov. 1985.

MIHAIES, George. Tsukuba exposition international. Futuribles, Paris, p.90-100, déc., 1983.

MORIN, Edgar. Science avec conscience. Paris: Fayard. 1990. 320p.

MORUS, Thomás, A Utopia. $8^{a}$ edição. Tradução de José Marinho. Lisboa: Guimarães, 1992. 174p. Traduzido de "De optimo reipublicae statu de que nova insula utopia"

MOTTA, Paulo César Delayti. As interações entre institutos de pesquisa públicos e o setor privado. IN: Simpósio Nacional de Pesquisa administração em Ciência e Tecnologia, 1991, São Paulo. Anais... São Paulo. USP/FEA/PACTo, 1991. v.II, p.F-282-298. 
MUNFORD, Lewis. A cidade na História. Tradução de Neil R. da Silva. Belo Horizonte: Itatiaia, 1965. (2 vol.). Traduzido de "The city in".

NASCIMENTO, Luiz Felipe M. do, ANTUNES Jr., J. Antonio V., SANTOS, F. Luiz Motta dos Pólos tecnológicos do Rio Grande do Sul. In: Simpósio Nacional de Pesquisa de Administração em Ciência e Tecnologia, 15, 1990, São Paulo. Anais... USP/FEA/PACTo, 1990 p.J.05.

NASCIMENTO, Paulo Trombo S., PERILO, Sérgio Alves. A tecnologia como condicionante do perfil de um pólo tecnológico: o caso de São José dos Campos. In: Simpósio Nacional de Pesquisa de administração em Ciência e Tecnologia, 16, 1991. P.G.23-G.39.

NIJKAMP, Peter, MARX, Ronald Van Der, ALTERS, Tleo. Evaluation of regional incubator profiles for small and medium sized enterprises, Regional Studies, Oxford G.B., V. 22, n. 2, 95-105, 1987.

OAKEY, R.P., THWAITES. A. T., NASH. P.A. The regional distribution of innovative manufacturing establishments in Britain. Regional Studies, Oxford, G.B., V.14, p.235$253,1980$.

OKABE, Hiroji. Algumas reflexões sobre a formação do capitalismo japonês. Revista Argumento./s.1/ p.51-63, jan.1974.

PAIX, Catherine, PETIT. Michèle. Logiques hétitées, nouvelles stratégies: les groupes capitalistes de Taiwan et de Singapour face aux défis de I'internationalisation. Revue Tiers Monde, Paris, t. 21, n.124. p. 735-762, oct-déc. 1990.

(OS) PARQUES tecnológicos já são 650. Gazeta Mercantil. São Paulo, 28 maio 1993.

PATRÍCIO, Solange. Alta tecnologia à mineira. Dados e Idéias. São Paulo, p.22-29. dez. 1985.

PEREIRA: Mauricio Guedes, EMMERICK, Ma. Cristina et al. A experiência brasileira. In: Seminário Internacional Parques Tecnológicos. 1987, Rio de Janeiro. Anais... Rio de Janeiro: COPPE/CNPq, 1987, p. 108-157.

PÉREZZ, Carlota. Revoluciones tecnologicas y transformaciones sócio-institucionales. In: Seminário Jorge Sabato, 2,/s.d./ Sussex. Anales...Sussex: Universidad de Sussex,/s.d./.

PERILO, Sérgio Alves. Organização de intermediação em transferência de tecnologia: seu papel na inovação tecnológica. São José dos Campos: INPR, 1987. 271p. Dessetação (Mestrado em Análise de Sistema e aplicações). Instituto Nacional de Pesquisa Espacial, $1987 /$

PETRELLA, Riccardo, L'Europe et la RxD endustrielle. Futuribles. Paris, p.3-50, juin 1984. . La mondialisation de la technologie et de I'economie. Futuribles. Paris, p. 3-25, sept 1989.

QUERE, M: (coord.), Evaluation du Parc de Sophia-Antipolis: strategies d' entreprises et "milieu technopole". Marseille: Centre d'Economie Régionale/Université d' AixMarseille III/ CNRS, 1987. 134p. (rapport).

RACHID. Alessandra. O Departamento de engenharia de materiais da UFSCar e seu relacionamento com o setor produtivo. In: Simpósio Nacional de Pesquisa de 
Administração em Ciência e Tecnologia, 16, 1991. São Paulo, Anais..., USP/FEA/PACTo, 1991, p. F.22-F.44.

RANGEL, Ignácio. O Quarto ciclo de Kondratiev. Revista de Economia Política Rio de Janeiro, v.10, n.4, p.31-43, out-dez, 1990.

RATTNER, Henrique. Tendência e perspectivas da economia internacional. Conferencia no Instituto de Estudos Avançados. USP, 1989. (mimeografo).

REIS. Marcos Aarão. Cariocas unem-se. Dados e idéias, São Paulo, p.12, mar, 1986.

RIUS, Mireille, L'emergence du pôle technologique de Campinas. Document de Recherche du CREDAL. Paris, n. 204, p. 46-57, 1989.

RODNEY, Alan, Du redéploiment aus Science parks. Autrement: Techonopolis, I' explosion des cités scientifiques: USA- Japon-Europe, Paris, n.74, p. 108-111, nov. 1985.

RODRIGUES, Leonel Cezar. O modelo externalista como estrutura organizacional de pesquisa. In: Simpósio Nacional de Gestão da Inovação Tecnológica, 17, 1992, São Paulo. Anais... São Paulo, USP/FEA/PACTo, 1992 p, 631-642.

RUSSO, Giuseppe. WELSCH, Harold. Decisions in creating na incubator. In: Congresso Internacional de pequenos negócios, 13, 1986/s. 1../Anais.../s./oct., 1986 p. 1-33.

RYANS Jr., Jonh K., SHANKLIN, WILLIAN L. Implemeting a high-tech center strategy-the marketing program. In: SMILLOR, R. KOZNETZKY, George, GIBSON, David V. Creating the technopolis. Cambridge, Massachusetts: Bullinger Publishing Co. 1988, cap. 13, p. 209-219.

SALOMON, Jean-Jacques. Les politiques d'innovation em Europe. Futuribles, Paris, p. 2952. Maio 1989.

SANTOS, Marli Elisabeth Ritter. A interdisciplinaridade no Centro de Biotecnologia de UFPRGS. In: Simpósio Nacional de Pesquisa de Administração em Ciência e Tecnologia, 16, 1991. São Paulo, Anais... São Paulo: USP/FEA/PACTo, 1991, p.F.263281.

SANTOS, Milton. O espaço dividido: os dois circuitos da economia urbana dos países subdesenvolvidos. Tradução de Myrna T.Rego Viana. Rio de Janeiro: Livraria Francisco Alves Edit. S.A., 1979, 345 p. Traduzido de L'espace partagé. Les deux circuits de l'économie urbaine des pays sous-développés.

. Economia espacial: críticas e alternativas. Tradução de Marie Irene de Q.F. Szarecsányi. São Paulo: HUCITEC, 1979, 167 p. /s.t. original/.

Por uma geografia nova: da crítica da geografia a uma geografia crítica. $2^{\mathrm{a}}$ edição. São Paulo: HUCITEC, 1980, 236 p..

L'épistémologie des sciences sociales. Revue International des Sciences Sociales, Paris, v.36, n. 4, 1984, p. 691-707.

Espaço e método. São Paulo: Nobel, 1985, 88p.

. Metamorfoses do espaço habitado. São Paulo: HUCITEC, 1988, 124p.

- A geografia técnica. Conferência: Associação dos geógrafos brasileiros, seção de Fortaleza, 28-05-93 (mimeografado). 
- O retorno do território. Conferência: Seminário Território; Globalização e Fragmentação. ANPUR/USP. 28/04/1993 (mimeografado).

SANTOS, Sílvio A. dos. Os parques tecnológicos, incubadoras e a criação de empresas de alta tecnologia. In: Simpósio Nacional de Pesquisa e administração em Ciência e Tecnologia. In: Simpósio Nacional de Pesquisa e Administração em Ciência e Tecnologia, 12, 1987. São Paulo. Anais... São Paulo: /USP/FEA/PACTo, 1987.. p. 642_655.

SANTOS, Theotônio dos. Economia mundial, integração regional e desenvolvimento sustentável- as novas tendências da economia mundial e a integração latino-americana. Petrópolis: Vozes, 1993, 144p.

SÃO PAULO (Estado). Secretaria de Economia e Planejamento. Coordenadoria de ação regional. Escritório Regional de planejamento de São Carlos. Diagnóstico Regional: Região de São Carlos. São Carlos, 1990, 74p. (versão preliminar).

SAXENIAN, Anna Lee. Silicon Valley and Route 128: regional prototypes: or historic exceptions? In: Castells Manuel (ed). High tech space and society. Beverly Hills: Saga Publications, 1985. Cap. 4, p. 81-105.

SBRAGIA, Roberto. Características de equipes bem sucedidas de inovação tecnológica. In: Simpósio Nacional de Gestâo da Inovação tecnológica, 17, 1992 p. 643-655.

SCHUMACHER, E.F.. O negócio é ser pequeno. $3^{a}$ edição. Tradução de Octávio Alves Velho.

Rio de janeiro : Zahar. 1981, 261p. Título original: "Small is beautifill".

SCHUMPETER, J.A. Capitalismo, Socialismo y Democracia. Buenos Aires: Ed.Claridad, 1946.

. Teoria do desenvolvimento econômico. Trad. : Maria Sílvia Possas . S. Paulo: Abril Cultural, 1982. 169p. Título original: Theorie de Wirstschaftlichen Entwickung.

SCOTT, Allen J. New industrial spaces: flexible production organization and regional development in North America and Western Europe. London: Pion, 1988. 131p.

Produção flexíbel e desenvolvimento regional ou desenvolvimento regional reconsiderado. Conferência: USP, São Paulo, 1990.

SCOTT, A. J. STORPER, Michael. Indústria de alta tecnologia e desenvolvimento regional: uma crítica e reconstrução teórica. Espaços \& Debates. São Paulo, v. 8, n. 25,n. 33-44, 1988.

SOUZA, Maria Adélia A. de. Regionalização: tema geográfico e político, o caso paulista. Boletim Paulista de Geografia. São Paulo, n. 50, p. 130-142, mar, 1976.

SOUZA NETO, J. Adeodato, STAL. Eva. Financiamento de risco para a inovação tecnológica na empresa. In: Simpósio Nacional de Pesquisa e Administração em Ciência e Tecnologia, 15, 1990, São Paulo. Anais ... São Paulo: FINEP/PACTo/FEA/USP. 1990 p.B.01.

STEED, Guy B.F., DEGENOVA, Don. Ottava's technology-oriented complex. The Canadian Geographer. Toronto: Canadian Association of Geographer/ University of Toronto Press, v.23, n.3, p. 263-278, fall/autonne, 1983.

STERNBERG, Rolf. Innovation centres and their importance for the growth of technologybased firms. Experience gained from the Federal Republic of Germany. Technovation. 
SUNMAN, Hilary, Science and technology parks in Belgiun and the Netherlands, Cardiff: CSP Economic Publication, 1986, 87p.

SUZIGAN, Wilson. A indústria brasileira após uma década de estagnação: questões para política industrial. Economia e Sociedade. Campinas, n. 01, p. 89- 109, ag. 1992.

SWIFT, Jonathan. Viagens de Gulliver. Tradução (adaptação) de Clarice Lispector, São Paulo: Abril Cultural . 1973. 218p. Título original: Gulliver's Travels.

TAKAHASHI, Nobuo. A new concept in building : Tsukuba Academic New Town. Ekistics,/ s.1/.v.48,n.289, p.301-106, jul/aug. 1981.

TESSE/Pierre-Yves. DU sexe des technolopes, Autrement: Technopolis, I'explosion des cités scientifiques: USA-Japon-Europe. Paris n. 74,p. 156-158. Nov. 1985.

TORKOMIAN, Ana Lúcia Vitale. Estrutura de pólos tecnológicos: um estudo de caso. São Paulo: USP. 1992. 193p. Dissertação (Mestrado em Administração). Faculdade de Economia e Administração. Universidade de São Paulo. 1992.

TRUZZI, Osvaldo Mário Serra. Café e indústria: São Carlos: 1850-1950, São Carlos: UFSCar/Arquivo de História contemporânea, 1986. 270p.

UNITED KINGDON SCIENCE PARK ASSOCIATION. Summary of operational, Science parks in the UK. London, 1989. 4p.

UNIVERSIDADE DE SÃO PAULO: Campus de São Carlos- Sumário informativo. São Carlos. 1973, 12p.

UNIVERSIDADE DE SÃO PAULO/ESCOLA DE ENGENHARIA. Informações $\mathbf{n}^{\mathbf{0}} \mathbf{1 2 9}$. São Paulo. 1983, 8p.

UNIVERSIDADE DE SÃO PAULO/DEPARTAMENTO DE QUÍMICA E FÍSICA MOLECULAR. Relatório de atividades de 1989. São Carlos. 1989. 53p.

UNIVERSIDADE DE SÃO PAULO/DEPARTAMENTO DE FÍSICA E CIÊNCIA DOS MATERIAIS. Relatório de atividades de 1989. São Carlos, 1989. 469p.

UNIVERSIDADE DE SÃO PAULO/ESCOLA DE ENGENHARIA. Atividades de maior relevância 1989-1990. São Carlos, 1989, 53p.

UNIVERSIDADE DE SÃO PAULO/INSTITUTO DE QUÍMICA E FÍSICA. Relação das dissertações e teses. 1985- 1990. 42p.

UNIVERSIDADE DE SÃO PAULO Anuário estatístico: 1990. 222p.

Relação dos professores, com indicações de diplomas. São Carlos. 1990. 8p.

UNIVERSIDADE FEDERAL DE SÃO CARLOS. Relatório anua de atividades de 1987. São carlos 1988. 407p.

20 anos. São Carlos, 1990, 46p.

Produção intelectual de 1988. São Carlos, 1989. 136p.

Catálogo dos Cursos de mestrado e doutorado. São Carlos, 1989. 92p.

UNIVERSIDADE FEDERAL DE SÃO CARLOS, Departamento de Engenharia de Materiais. Catálogo de programa integração escola-empresa-governo. São Carlos, 1989. $13 p$. 
. Serviços à comunidade - SEC. São Carlos, 1989. 21p.

$1989.51 \mathrm{p}$.

Progama de pós-graduação em ciência e engenharia e materiais. São Carlos,

Relatório: atividade de 1989, São Carlos. 1990,199p.

UNIVERSIDADE FEDERAL DE SÃO CARLOS. Departamento de Engenharia de Produção. Relatório anual 1989. São Carlos. 1989. 43p.

. O Departamento e seus cursos. São Carlos, 1990, 48p.

UNIVERSIDADE FEDERAL DE SÃO CARLOS. Departamento de Engenharia Química. Relatório anual 1989. São Carlos 1989, 47p.

UNIVERSIDADE FEDERAL DE SÃO CARLOS, Departamento de Química. Relatório geral. São Carlos, 1989, 118p.

Informações e atividades desenvolvidas. São Carlos, 1990. 35p.

UNIVERSIDADE FEDERAL DE SÃO CARLOS, Departamento de Engenharia de Produção. Centro de Ciência e Tecnologia. Relatório anual. 1989. São Carlos. 1989. 12p.

. O Departamento e seus cursos. São Carlos, 1990. 48p.

UNIVERSIDADE FEDERAL DE SÃO CARLOS. Departamento de Engenharia de Química. Relatório Anual 1989. São Carlos, 1989. 47p.

UNIVERSIDADE FEDERAL DE SÃO CARLOS. Departamento de Química. Relatório Geral. São Carlos, 1989, 118p.

. Informações e Atividades Desenvolvidas. São Carlos, 1990. 35 p.

UNIVERSIDADE FEDERAL DE SÃO CARLOS. Centro Ciência e Tecnologia. Relatório Anual 1989. São Carlos, 1989. 12p.

VASCONCELOS, Eduardo. Administração da inovação tecnológica no Japão: potencialidade, fraquezas e perspectiva. In: Simpósio Nacional de Gestão da Inovação Tecnológica, 17, FEA/PACTo, 1992. São Carlos, 1992. São Paulo: Anais...p. 356-373.

VEJA, Veja no interior - São Carlos. São Paulo: Abril, v.22, n. 43, nov. 1989, 16p. (Edição especial).

VEJA, São Carlos: processo a passos largos. São Paulo: Abril, v. 23, n. 48, 1990. 8p. Suplemento.

VISÃO. São Carlos: em ritmo de século XXI. São Paulo: Ed. Visão, ago., 1988. 20p. Informe especial.

VOGEL, Steven. Del bonsai ao bosque. El dia. Madrid. 18out. 1990.

WACHTEL, Hovard. Os mandarins do dinheiro: as origens da nova ordem econômica supra nacional. Tradução de Roberto Raposa. Rio de Janeiro: Nova Fronteira, 1988. 214p. Título original: The Money mandarins.

WATSON, J.A. Campus-linked incubator centre developments. Industry \& Higher Education/ s.1/ p. 20-25, sept. 1987. 